Universidade de Brasília

Instituto de Relações Internacionais

Programa de Pós-Graduação em Relações Internacionais

Leonardo Carvalho L. A. Bandarra

\title{
A luta contra o Tordesilhas Nuclear: três momentos da política nuclear brasileira (1969- 1998).
}

Struggling with the Nuclear Tordesillas: three moments of the Brazilian nuclear policy (1969-1998).

Dissertação de mestrado acadêmico apresentada ao Programa de PósGraduação em Relações Internacionais da Universidade de Brasília.

Área de concentração: História das Relações Internacionais

Orientador: Antônio Carlos M. Lessa 


\section{Agradecimentos}

Agradeço, primeiramente, ao Deus trino e a Maria Santíssima, pela presença sempre constante. Agradeço também à minha família, em especial a minha mãe, Luciana, meu pai, Leonardo, minha irmã, Camilla, minha vó, Sílvia, e a meus tios Angela, José e Marisa pelo grande apoio que me deram e pelo incentivo durante os dois anos de pesquisa, cujo resultado final foi esta dissertação. Por fim, agradeço imensamente a meu orientador, Antônio Carlos Lessa, pela supervisão critériosa e pelos valorosos conselhos dados durante os últimos anos de convivência. 


\section{Sumário}

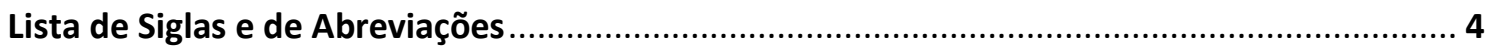

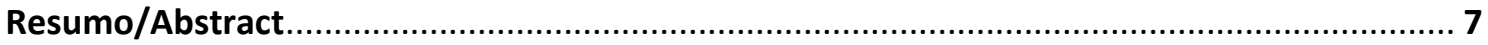

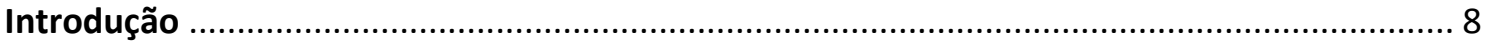

Capítulo 1: A política brasileira de não proliferação nuclear: a perspectiva nacional de

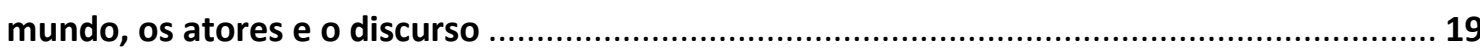

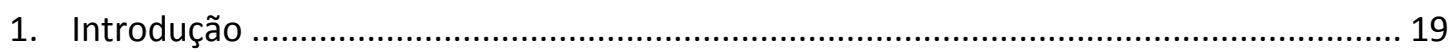

2. Os rumos da Política Nuclear Brasileira: os principais atores internos ........................... 19

3. Princípios e diretrizes da política nuclear brasileira ........................................................... 33

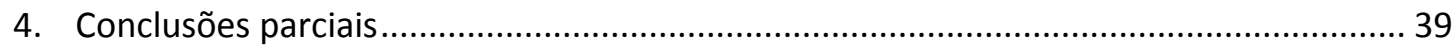

Capítulo 2: A implementação do complexo nuclear brasileiro (1969-1978): a primazia do Eixo

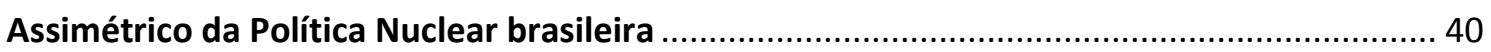

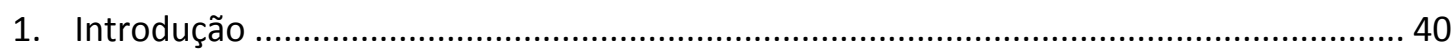

2. O panorama energético brasileiro na década de 1970 ................................................... 42

3. Cooperação tecnológica, rapidez e efetividade: as tratavas de Médici e a parceria com os

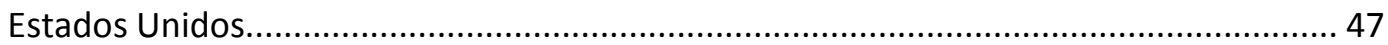

4. Tempos de adaptação: a política nuclear de Geisel .............................................................. 48

4.1. Novos condicionantes domésticos e externos ....................................................... 50

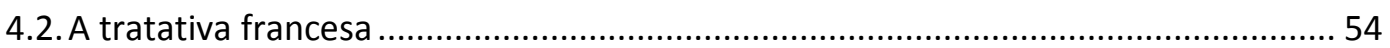

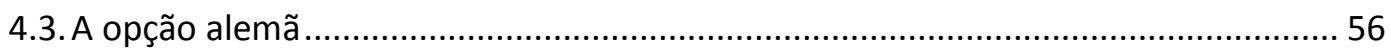

4.4. O início da desilusão: a URENCO e as exigências inglesas e holandesas ..................... 68

5. O Eixo Regional: a Argentina e o afastamento brasileiro do regime internacional de não

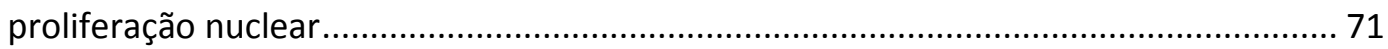

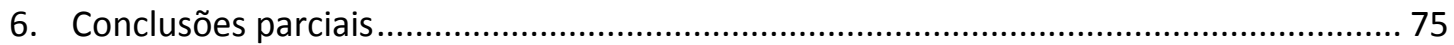

Capítulo 3: Voltando-se para dentro (1979-1989): a emergência do Eixo Sul, a aproximação

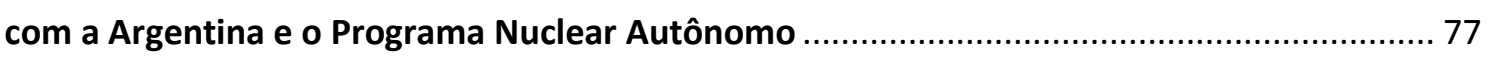

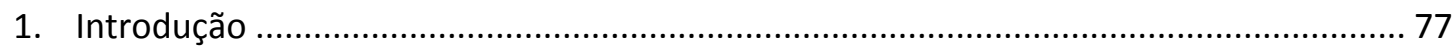

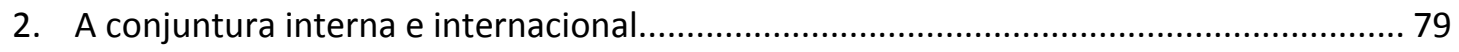

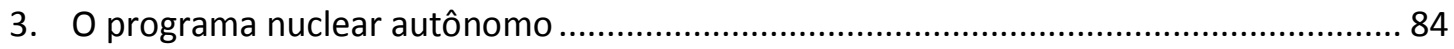

4. Desilusão: cenário externo desfavorável, crise da dívida externa, crise energética,

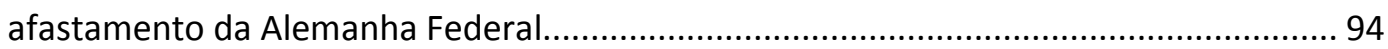

5. A aproximação com a Argentina: o Eixo Regional .......................................................... 97

6. Cooperação horizontal para tecnologia sensível: o Eixo Sul (Iraque, China, África do Sul, México) 106

7. Conclusões Parciais 113 
Capítulo 4: A renovação de credenciais (1990-1998): a adaptação do Brasil ao regime internacional de não proliferação nuclear

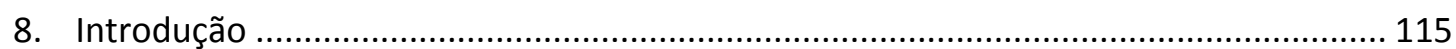

9. A política nuclear e os novos paradigmas da inserção internacional do Brasil ............... 117

10. A institucionalização da cooperação estratégica no campo nuclear: o Eixo Regional, a

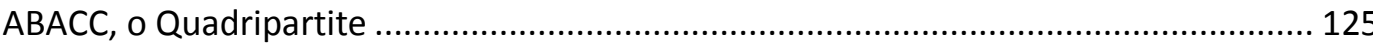

11. A reaproximação com o Eixo Assimétrico: Alemanha, Estados Unidos, TNP ................. 136

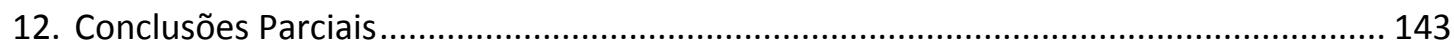

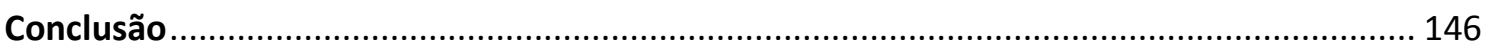

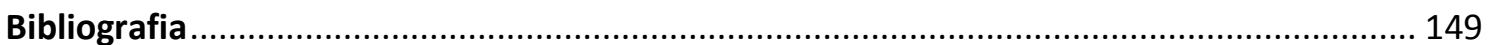

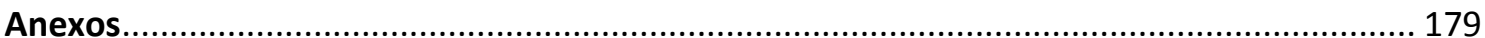




\section{Lista de Siglas e Abreviações}

AA. Auswärtiges Amt (Ministério dos Assuntos Estrangeiros alemão)

ABACC Agência Brasileiro-Argentina de Contabilidade e Controle AGNU Assembleia Geral das Nações Unidas

AIE. Agência Internacional de Energia

AIEA Agência Internacional de Energia Atômica

ALCA Área de Livre Comércio das Américas

CEA Commissariat à lÉnergie Atomique (França)

CESP .Companhia Energética de São Paulo

$\mathrm{CF} / 88$ Constituição Federal de 1988

$\mathrm{CN}$ Congesso Nacional

CNEA. Comisión Nacional de Energía Atómica (Argentina)

CNEN Comissão Nacional de Energia Nuclear

CPI. Comissão Parlamentar de Inquérito

CPMI Comissão Mista Parlamentar de Inquérito CSN. Conselho de Segurança Nacional

CTBT Tratado de Interdição Completa de Ensaios Nucleares

Eletrobrás. Eletrobrás Termonuclear S.A.

ENGESA Engenheiros Especializados S.A. ESG. Escola Superior de Guerra 
FMCT-Verification..........Sistema de Verificação do Tratado de Cortes de Material Físsil (Fissile Material Cut-off Treaty)

FRAMATOME Societé Franco-Américaine de Constructions Atomiques S/A (França)

Furnas Furnas Centrais Elétricas S.A.

GSN. Grupo de Supridores Nucleares

IMBEL .Indústria de Material Bélico do Brasil

INFCIRC Information Circular of the International Atomic Energy Agency IPEN .Instituto de Pesquisas Energéticas e Nucleares $\mathrm{JB}$ Jornal do Brasil

KWU Kraftwerkunion (Alemanha)

MAD Destruição Mútua Assegurada MCTI. Ministério de Ciência, Tecnologia e Inovação

Mercosul Mercado Comum do Sul

MME. Ministério de Minas e Energia MRE Ministério das Relações Exteriores MTCR Missile Technology Control Regime

NUCLAM Nuclebrás Auxiliar de Mineração S.A. NUCLEBRÁS Empresas Nucleares Brasileiras S/A NUCLEI Nuclebrás Enriquecimento Isotópico S.A. 
NUCLEP Nuclebrás Equipamentos Pesados S.A.

OPANAL .Organismo para a Proscrição das Armas Nucleares na América Latina e no Caribe

OPEP. .Organização dos Países Exportadores de Petróleo OTAN .Organização do Tratado do Atlântico Norte

PEI. Política Externa Independente PND. Plano Nacional de Desenvolvimento SAE. Secretaria de Assuntos Estratégicos SCCC Sistema Comum de Contabilidade e Controle de Materiais Nucleares

$\mathrm{SF}$ Senado Federal

SNI. Serviço Nacional de Inteligência TNP. Tratado de Não Proliferação Nuclear Uranio Mexicano

URSS União das Repúblicas Socialistas Soviéticas USP Universidade de São Paulo Zona da Paz e Cooperação do Atlântico Sul 


\title{
Resumo
}

A presente dissertação avalia como o Brasil adaptou sua política nuclear ao regime internacional de não proliferação nuclear e destaca qual o papel das relações bilaterais do Brasil nesse processo. Argumenta-se que a adesão brasileira ao regime internacional de não proliferação nuclear adveio tanto do interesse brasileiro em obter tecnologia do Norte Global quanto da aproximação com a Argentina. Para desenvolver a narrativa histórica, definiram-se três momentos do processo referido processo de adaptação: 1969-1978, nos governos Médici e Geisel, quando o Brasil definiu sua posição de repúdio ao TNP e sua estratégia de longo prazo de obter tecnologia nuclear para fins energéticos; 1979-1989, nos governos Figueiredo e Sarney, quando a estratégia de longo prazo foi modificada e se consolidou o programa nuclear autóctone; 1990-1998, nos governos Collor, Franco e Cardoso, quando o Brasil adaptou progressivamente sua política nuclear às instituições do referido regime, culminando com a adesão ao TNP. Além disso, para melhor organizar este estudo, foi elaborado o conceito de Eixos Bilaterais da Política Nuclear Brasileira, que busca classificar as relações bilaterais brasileiras, no campo atômico, em três categorias: o Eixo Assimétrico, o Eixo Sul, o Eixo Regional.

\begin{abstract}
This thesis evaluates how Brazil has adapted its nuclear policy the international regime of nuclear non-proliferation and highlights the role of bilateral relations in this process. It is argued that Brazil's accession to the international regime of nuclear nonproliferation stemmed both from Brazil's interest in obtaining technology from the Global North and from its rapprochement with Argentina. To develop the historical narrative, we settled three moments of that process of adaptation: 1969-1978, during presidents Medici and Geisel administrations, when Brazil defined its position regarding the rejection of the NPT, as well as its long-term strategy to acquire nuclear technology for energy purposes; 1979-1989, during presidents Figueiredo and Sarney administrations, when the Brazilian long-term strategy was modified and when the autonomous nuclear programme was consolidated; 1990-1998, during presidents Collor, Franco and Cardoso administrations, when Brazil progressively adapted its nuclear policy to the institutions of the aforementioned international regime, which culminated with the country's accession to the NPT. Moreover, in order to organise our study, we develop the conceptual of The Bilateral Axes of the Brazilian Nuclear Policy, which seeks to classify the Brazilian bilateral relations in the atomic field into three categories: the Asymmetrical Axis, the South Axis, the Regional Axis.
\end{abstract}

Palavras-Chave: Política Nuclear Brasileiro; Eixos Bilaterais da Política Nuclear Brasileira; Programa Nuclear Autônomo; Não proliferação de Armas Nucleares.

Keywords: Brazilian Nuclear Policy; Bilateral Axes of Brazilian Nuclear Policy; Autonomous Nuclear Programme; Nuclear Weapons Non-Proliferation. 


\section{Introdução}

O Brasil apresenta-se como relevante ator global no que concerne ao mercado global de minerais estratégicos, dentre os quais se destacam aqueles utilizados na indústria nuclear, como as areias monazíticas, o urânio e o nióbio ${ }^{1}$. A busca por instrumentalizar esses minerais na instalação de capacidade nuclear própria na matriz energética foi ensejo dos diversos governos brasileiros desde a década de 1950. Isso se deveu a promessas segundo as quais essa fonte de energia poderia sustentar o rápido crescimento brasileiro, bem como permitir ao Brasil recursos que apoiariam seu processo de desenvolvimento, o objetivo final da movimentação global do Brasil (CERVO, 1994).

Essa busca adquiriu consistência a partir de 1969, com o governo de Emílio Médici, quando, pela primeira vez, o Brasil impetrou a consolidação da incorporação de usina atômica funcional ao parque energético brasileiro, por meio de cooperação com os EUA $^{2}$. Nos anos seguintes, a política nuclear passou por três momentos de definição, em meio aos quais se materializou sua progressiva adaptação ao regime internacional ${ }^{3}$ de não proliferação de armas atômicas. Esses três momentos serão aqui analisados e demonstram como o Brasil transformou sua percepção abrangente sobre as possibilidades de uso de energia nuclear.

O primeiro momento inicia-se com o governo Médici, quando o Brasil consolidou sua postura externa crítica às instituições ${ }^{4}$ vigentes do regime internacional de não

\footnotetext{
${ }^{1}$ A posse desses recursos justifica a participação brasileira no Grupo de Fornecedores Nucleares em posição singular, visto que detém o quase monopólio do mercado mundial de nióbio, com 92,06\% do total mundial (IBRAM, 2012) e é relevante produtor de pó de urânio, também conhecido como yellow cake. As reservas brasileiras de urânio totalizam 310 mil toneladas (MARIN, 2010).

${ }^{2}$ Apesar de se haver optado por iniciar o período aqui analisado em 1969, ressalta-se que não essa não se trata de uma data definitiva e inequívoca para iniciar a análise aqui proposta. Escolheu-se esse ano, principalmente, por se tratar do início do governo Médici e do início do período de mais enfática crítica ao TNP. Outras datas poderiam ter sido igualmente adotadas, como, por exemplo, 1967, quando da confecção do Tratado de Tlatelolco, cuja relevância para a América Latina é indiscutível. Para uma análise mais detida sobre o período anterior ao aqui estudado, recomenda-se a leitura do artigo Patti $\left(2014^{\mathrm{a}}\right)$.

${ }^{3}$ Por regime internacional, entende-se "princípios implícitos ou explícitos, de normas, regras, decisão e procedimento sobre as expectativas de convergência dos atores num certo ramo das relações internacionais" (KRASNER, 1982, p. 187, tradução livre). Como opção teórica, optou-se aqui por utilizar esse termo de forma intercambiável com "instituições internacionais", que abrange o tanto as organizações, estruturas físicas nas quais Estados participam com representantes, quanto o conjunto de normas, valores e regras que regem as relações entre Estados, criando ordem em meio à anarquia internacional (Simmons; Martin, 2007). È, portanto, conceito abrangente, em cujo escopo estão instituições físicas e normativas.

${ }^{4}$ Por instituições internacionais, entende-se o "conjunto de tanto as organizações, estruturas físicas nas quais Estados participam com representantes, quanto o conjunto de normas, valores e regras que regem as relações entre Estados, criando ordem em meio à anarquia internacional" (SIMMONS; MARTIN, 2007: 192, tradução livre).
} 
proliferação. Essa crítica baseou-se, principalmente, na necessidade que a diplomacia brasileira verificava, desde o segundo governo Vargas, de consolidar regime internacional efetivo tanto do lado do desarmamento quanto da não proliferação horizontal $^{5}$. Essa postura justificara a negativa da diplomacia nacional de aderir ao principal instrumento significador do regime internacional de não proliferação, o Tratado de Não Proliferação (TNP), ainda em 1969 (FONSECA JR, 1998: 260).

De fato, como abordado pelo título desta dissertação, o TNP fora visto, segundo termos de Mário Pessoa (apud Danilo Venturini, CN, 1990: 12), como uma espécie de “Tordesilhas Nuclear”, na medida em que dele decorreu divisão injusta do mundo entre dois grupos de países - aqueles com "dependência tecnológica” e aqueles com o pleno domínio da tecnologia atômica. Embora esse tratado não seja o único instrumento característico do regime internacional de não proliferação nuclear, ele foi aquele elegido pela política externa brasileira como principal alvo de suas críticas e de suas preocupação, na medida em que era tratado o qual se pretendia síntese dos objetivos de não proliferação definidos pelas grandes potências e garante de divisão internacional injusta do poder.

Paralelamente às críticas ao regime internacional de não proliferação, o governo Médici propugnou tratativas internacionais com os Estados Unidos, no sentido de obter a instalação de matiz nuclear no parque energético brasileiro. Isso se daria por meio da cooperação internacional, a qual também foi estratégia usada por seu sucessor, Ernesto Geisel para obter tecnologia atômica própria. Em meio a conjuntura internacional crescentemente desfavorável aos interesses brasileiros (e.g. fim do padrão dólar-ouro, consolidação da economia de plutônio ${ }^{6}$, Choque do Petróleo de 1973), Geisel modificou a estratégia de Médici e abriu as opções externas brasileiras, coadunando-as com o viés globalista (PINHEIRO, 2000) ${ }^{7}$ de sua política externa. Essa abertura das alternativas

\footnotetext{
5 Segundo conceituação oficial, explanada Zhenqiang (2004), as ações de combate à proliferação de armas nucleares dividem-se em duas vertentes: a não proliferação vertical, ou desarmamento, pela qual os países detentores de armas nucleares reduzem seus estoques existentes; a não proliferação horizontal, pela qual os países desnuclearizados são impedidos de obter armas nucleares.

${ }^{6}$ A economia de plutônio refere-se aos avanços tecnológicos ocorridos no final da década de 1960 e que possibilitaram barateamento do processo de enriquecimento de urânio, bem como facilitaram o acesso ao plutônio, elemento químico resultante do processo de enriquecimento de urânio e utilizado para a fabricação de bombas nucleares (BRENNER, 2009, p. 75-76). Esse processo será abordado no capítulo 2 desta dissertação.

${ }^{7}$ Quanto à utilização dos termos americanista e globalista, vale salientar que se trata de uma discussão conceitual recentemente elencada por pesquisadores como Letícia Pinheiro (2000) e como Cristina Pecequilo (2005, 2012), a qual intenta demostrar as diferentes conferidas às relações com os Estados Unidos pelos diversos governos brasileiros. Dessa forma, consolidação de paradigma americanista não implica completo repúdio às relações com os Estados Unidos, tampouco o contrário. Trata-se, tão
} 
implicou aproximação com os países da Europa Ocidental, em especial França e Alemanha, com a qual o Brasil firmou abrangente arcabouço institucional de cooperação no setor atômico, cujas bases foram o Acordo Brasil-Alemanha de 1975.

O segundo momento abarcou os governos Figueiredo e Sarney, entre 1979 e 1989, quando se identificou transformação com a estratégia de desenvolvimento adotada na década anterior. Figueiredo, diferentemente de Médici e de Geisel, empreendeu desenvolver tecnologia nuclear por meio de vias autóctones. Foi-se instalado, então, o programa autônomo, delineado desde final da administração Geisel e cujo objetivo era adquirir capacidade nuclear própria sem auxílio de parcerias tradicionais. Apesar de esse programa voltar-se, primordialmente, para os meios nacionais, ele também levou o país a ensaiar parcerias com países do Sul Global ${ }^{8}$, como China, México e Iraque.

Apesar da democratização do país, em 1985, a abertura e a busca de transparência do poder público não atingiram, de imediato, a política nuclear brasileira. Sob Sarney, foram mantidas as diretrizes básicas da política nuclear brasileira, com alterações graduais e substantivas ocorridas ao final do mandato, decorrentes, em especial, das discussões ocorridas em meio à Assembleia Nacional Constituinte. Foi também nesse período, vale lembrar, que o Brasil atingiu domínio do ciclo completo do enriquecimento de urânio, como anunciado pelo presidente Sarney, em 1987, e que o Brasil iniciou aproximação estratégica com a Argentina, ocasionada desde o governo Figueiredo, por força da crise do Canal de Beagle e da Guerra das Malvinas.

O terceiro momento abrange a década de 1990, desde o governo Fernando Collor (1990-1992), até a adesão do Brasil ao TNP, em 1998, no governo Fernando Henrique Cardoso, o que marcou a completa adesão do Brasil às instituições do regime internacional de não proliferação nuclear. Nesse período, o Brasil implementou parceria íntima e estruturada com a Argentina e aderiu, progressivamente, às instituições globais de salvaguardas nucleares, inicialmente por meio da criação da Agência BrasileiroArgentina de Contabilidade de Controle (ABACC) e do Tratado Quadripartite entre Brasil, Argentina, ABACC e Agência Internacional de Energia Atômica (AIEA), em 1991, e da retirada das reservas feitas ao Tratado de Tlatelolco, em 1994. Esse processo

somente, de uma divisão analítica, a qual permite melhor compreender como se modificou a autopercepção brasileira ao longo da história da política externa.

${ }^{8}$ O termo "Sul Global", o qual se refere aos países do antigo Terceiro Mundo, ou grupo dos países em desenvolvimento, principalmente a partir do período pós-Guerra Fria, não era utilizado nas décadas de 1970 e de 1980, como demonstrado pelas citações diretas e indiretas expostos nesta dissertação. Utilizarse-á, contudo, essa terminologia quando se referir à aplicação do conceito de Eixos Bilaterais da política nuclear brasileira, porquanto se trata da base terminológica e teórica que embasa sua criação. 
foi confirmado e aprofundado com a adesão brasileira ao Regime de Controle de Tecnologia de Mísseis (MTCR), ao Grupo de Supridores Nucleares (GSN) e ao TNP. Apesar de mantidos os preceitos fundamentais da posição internacional brasileira no campo da não proliferação nuclear, verificou-se, nesse período, modificação do discurso brasileiro, no sentido de enfatizar a necessidade de participação no regime internacional vigente (HIRST, PINHEIRO, 1995; VIGEVANI, et al, 2003).

Esse caminho de adesão que marcou o terceiro momento não foi consequência natural daquilo desenvolvido nos momentos anteriores, mas fruto de escolhas políticas tomadas junto ao processo de modernização da política externa e adaptação ao novo momentum internacional pós-Guerra Fria. A escolha clara por não obter armas nucleares, definida pelos governos Collor, Franco e Cardoso, distanciou esses governos de seus predecessores, especialmente Figueiredo e Sarney, e marcou nova estratégia de inserção no mercado nuclear global. Essa nova estratégia modificou a compreensão acerca do que consistia a luta contra o Tordesilhas Nuclear, porquanto se substituiu a conflagração discursiva contra as instituições do regime internacional de não proliferação nuclear pela busca de modificar essas instituições desde o interior do próprio regime. Ou seja, passou-se a tentar impor a modificação das regras por meio da adesão a esse regime e a suas instituições, na linha da "autonomia pela integração", característica do governo Cardoso (VIGEVANI et al, 2003).

Para melhor analisar os desenvolvidos ocorridos nos três momentos aqui definidos, no período entre 1969 e 1998, propôs-se a seguinte pergunta de pesquisa: como se conformou o processo de adaptação da política nuclear brasileira ao regime internacional de não proliferação nuclear?. Essa pergunta será respondida por meio da análise dos três momentos da política nuclear brasileira e por meio do instrumento conceitual dos eixos bilaterais da política nuclear brasileira, explicitados a seguir. A análise mais detida dos três momentos, além disso, mostrará que se verificou não somente a modificação da política nuclear brasileira, mas também a gradual transformação do próprio regime internacional de não proliferação de armas nucleares. Tratou-se, portanto, de uma processo de transformação concomitante, cujo resultado final foi redução das divergências entre ambos - o regime internacional de não proliferação e a política nuclear brasileira.

Analisar e identificar, nesses três momentos, o impacto das relações bilaterais brasileiras no processo de adaptação da política nuclear brasileira ao regime internacional de não proliferação nuclear é, além disso, o objetivo principal dessa 
dissertação, cujo argumento principal é: a adesão brasileira ao regime internacional de não proliferação nuclear adveio tanto do interesse brasileiro em obter tecnologia do Norte Global quanto da aproximação com a Argentina. Esse argumento será corroborado ao se abordar os três momentos antes definidos de forma mais detida. Verificar-se-á que apenas em 1990 essa aproximação ocorreu, porquanto, nos governos Médici e Geisel o Brasil teria flertado com a possibilidade de aderir ao TNP, as relações turbulentas com a Argentina foram elemento fundamental para inviabilizar a aproximação com as intuições de não proliferação, ao passo que, nas administrações Figueiredo e Sarney foram as relações com o Norte Global aquelas arrefecidas.

Para realizar esse esforço, empreendeu-se busca e interpretação de fontes secundárias e primárias diversas. Além de artigos de autores brasileiros e estrangeiros, ponderou-se documentação diversa, advinda, principalmente, de arquivos como o do Ministério das Relações Exteriores do Brasil, em Brasília; da plataforma virtual do Wilson Center, de Washington; do CPDOC-FGV, no Rio de Janeiro; bem como artigos de jornais e periódicos; relatórios de organizações internacionais, como a ABACC, e da Comissão Parlamentar de Inquérito, de 1982, e da Comissão Mista Parlamentar de Inquérito, de 1990; textos de tratados internacionais; discursos de altas autoridades brasileiras e estrangeiras; documentação da CIA e do Departamento de Estado, disponibilizadas pelo Freedom of Information Act (FOIA) e por coletâneas de documentação oficial dos governos Nixon e Carter; documentação alemã, oriunda do parlamento daquele país (Deutscher Bundestag) e do Ministério das Relações Exteriores (Auswärtiges Amt), esta compilada nos diversos Akten zur Auswärtigen Politik der Bundesrepublik Deutschland.

Também se buscaram artigos de jornais e de periódicos contemporâneos ao período analisado, alguns encontrados em forma física na Biblioteca Central da Universidade de Brasília (BCE-UnB), e realizaram-se entrevistas com atores relevantes no processo de condução da política nuclear brasileira, em particular com inspetores da ABACC, as quais foram confrontadas com relatos concedidos por outras figuras fundamentais da condução da política nuclear brasileira e disponibilizados em fontes diversas, encontrados tanto virtualmente quanto em formato físico. Entre essas fontes, destacamse entrevistas concedidas a veículos de comunicação e a pesquisadores do próprio CPDOC-FGV.

Para melhor organizar os rumos da política nuclear brasileira nos três momentos indicados (1969-1978; 1979-1989; 1990-1998), elaborou-se o conceito de Eixos 
Bilaterais da Política Nuclear Brasileira, o qual pretende classificar os diversos caminhos pelos quais o Brasil buscou, no exterior, meios para implementar o objetivo declarado de adquirir tecnologia nuclear eficiente e abrangente. Esse conceito trata-se de um quadro geral, que pretende abarcar três subconjuntos de relações bilaterais específicas aqui definidos. São esses: o Eixo Assimétrico, o Eixo Sul, o Eixo Regional.

Esses três subconjuntos têm como objetivo ordenar as relações bilaterais brasileiras que foram utilizadas como ponte para conseguir tecnologia nuclear, segundo critérios identitários desenvolvidos teoricamente na linha teórica reflexivista das Relações Internacionais ${ }^{9}$. O critério definido como primordial foi a divisão entre Norte e Sul Global, a qual confronta o caráter homogeneizador da globalização, por meio da ênfase na divisão geopolítica entre países desenvolvidos e países periféricos (ROSA; 2015; DADOS, CONNELL, 2012).

O termo Sul Global busca substituir, de forma mais neutra e menos pejorativa (STUNKEL, 2014; JARDIM, 2015), as antigas categorizações de "Terceiro Mundo" e "periferia", porquanto enfatiza não tão somente os aspectos econômicos, mas também a trajetória histórica comum (e.g. colonialismo e imperialismo); os níveis de desenvolvimento socioeconômico, a proximidade geográfica e a estratégia de política externa de crítica as estruturas internacionais vigentes (ALDEN et al, 2010) ${ }^{10}$. Dessa forma, o Sul Global identificaria uma forma de identidade transnacional entre Estados e atores não estatais advindos de regiões não centrais do sistema internacional - da África, da Ásia, da América Latina, de parte da Europa e da Oceania (ALDEN et al, 2010; DADOS, CONNELL, 2012).

\footnotetext{
${ }^{9}$ A linha reflexivista das Relações Internacionais é terminologia abrangente, exposta por Robert Keohane (1988, apud WAEVER, 1997), se pretende ser termo capaz de abarcar as linhas teóricas não enquadradas no mainstream neo-neo, como as vertentes construtivistas e pós-modernas. Entre essas vertentes encontram-se aquelas que trazem à baila a discussão relativa a identidades e à co-construção social dos atores do sistema internacional. Uma análise mais detida sobre a crítica reflexivista e a aplicação ao campo da não proliferação nuclear foi publicada por nós no artigo "BANDARRA, L. C. Não-Proliferação Nuclear e Epistemologias Geoculturais: uma abordagem do debate teórico entre as teorias hegemônicas e os casos brasileiro e indiano. Revista de Estudos Internacionais, Vol. 7, No 1, 2016".

${ }^{10}$ Como afirmam Chris Alden, Sally Morphet e Marco Antônio Vieira (2010: 3), "the South is a phrase used to describe those regions of the globe that have in common a political, social and economic history rooted in the inequalities of a colonial or imperialist past. As the levels of economic development have evolved among the countries of the South over the last few decades, the concept has come to signify more than the discussion and making of foreign policy, geographic proximity or the sense of shared history. The South is also increasingly understood to be an ideological expression for the range of concerns facing developing regions, which themselves are growing in economic and political diversity and experience. In this sense it serves as a mobilising symbol for a diverse set of developing countries and is part of a strategy for managing relations with the more powerful industrialised countries of the North through its decision-making groupings - the Non-Aligned Movement (NAM), the G77, the Organisation of the Islamic Conference (OIC) and, more recently a range of sub-regional organizations like the Association of South East Asian Nations (ASEAN)."
} 
Não se trata, portanto, de divisão geo-referenciada, tão somente, mas de categorização mais ampla, capa embasada em aspectos identitários. Um exemplo pode ser dado, no campo nuclear, entre Brasil e Iraque, países que, apesar de estarem em hemisférios geográficos diferentes, podem ser conjuntamente abarcados no Sul Global devido à semelhança do discurso, na década de 1980, altamente crítico à divisão desigual de tecnologia entre os países do desenvolvidos e os demais. O Norte, por outro lado, englobaria os países desenvolvidos, principalmente Estados Unidos, Canadá Europa Ocidental, Japão, Israel, Austrália, Nova Zelândia (ALDEN et al, 2010; ROSA, 2015). São esses países aqueles com os quais os países com os quais os países do Sul, portanto também o Brasil, desenvolvem relações pautadas pela grande desigualdade de condições materiais de poder, ou seja, pela assimetria de condições de poder (LAFFER, 2004: 65; RICUPERO, 1995).

A partir da consideração entre Norte e Sul Global, organizam-se as relações bilaterais da política nuclear brasileira em três categorias, conforme explicitado pelo Diagrama 1, o qual recorta as principais parcerias bilaterais desenvolvidas ao longo do período estudado. As três categorias, cada uma contendo um conjunto de relações bilaterais, separam-se da seguinte forma: uma do Brasil com países do Norte Global, o Eixo Assimétrico, e dois do Brasil com os países do Sul Global, os Eixos Sul e Regional. Essa subdivisão das relações com o Sul Global deveu-se à singularidade das relações com a Argentina, as quais não possuíram função extremamente mais relevante no cálculo estratégico da definição da política nuclear brasileira do que os demais países do Sul Global. De fato, o Brasil apenas ingressou no regime internacional de não proliferação nuclear após a exitosa construção de medidas de confiança mútua com Buenos Aires, das quais decorreram consolidação de zona de paz regional no Cone Sul.

Diagrama 1 - Os três eixos da política nuclear brasileira entre 1969 e 1998

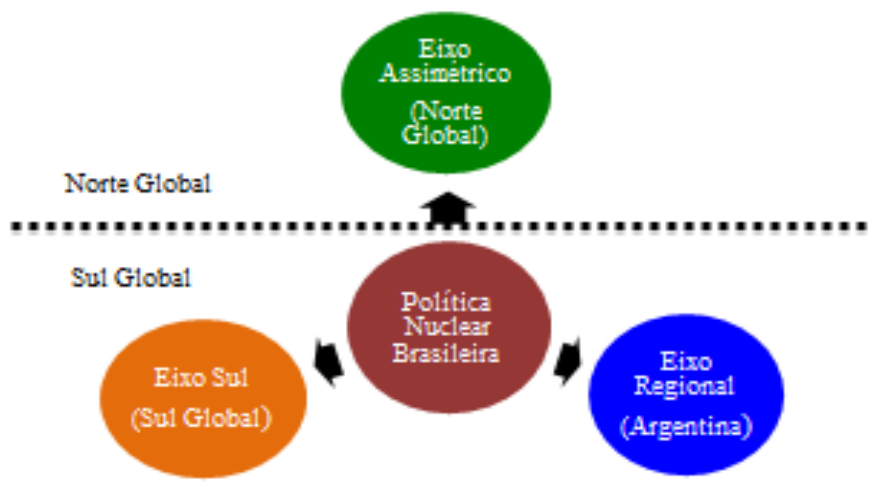


O Eixo Regional adéqua-se ao princípio historicamente definido do pragmatismo das relações internacionais do Brasil, entendido como a

\begin{abstract}
"adequação das percepções dos reais interesses nacionais aos desígnios externos, de forma a fazer prevalecer o resultado sobre o conceito, os ganhos concretos e materiais sobre os valores políticos ou ideológicos, a oportunidade sobre o destino, a liberdade de ação sobre o empenho do compromisso, o universalismo sobre as camisas-de-força dos particularismos, a aceitação sobre a resistência dos fatos" (CERVO, 1994: 27).
\end{abstract}

Trata-se, em suma, da adequação entre os interesses do Brasil, definidos pelo Estado e pelos grupos sociais que o comportam (e.g. obter energia nuclear para fins energéticos), com a real capacidade de o país concretizá-lo em meio ao cenário internacional.

As relações com a Argentina foram particularmente caracterizadas pelo pragmatismo durante toda a sua história, desde o período da rivalidade intermitente nos tempos colonial e imperial, passando pela cordialidade oficial, entre a Primeira República e a década de 1970, até a consolidação da parceria estratégica, iniciada no governo Figueiredo e concretizada com Collor (CERVO, BUENO, 2011; SARAIVA, 2012; SPEKTOR, 2002). Constitui-se, nesses séculos de história conjunta, identidade conjunta própria e consolidada, sobre a qual os dois países, Brasil e Argentina, implementaram ingresso conjunto em diversos regimes internacionais globalmente consolidados, como o de não proliferação nuclear, por meio da criação do sistema ABACC-Quadripartite. Tratou-se, dessa forma, de aproximação pragmática com a Argentina rumo à constituição de identidade mais próxima, operacionalizada, no campo nuclear, por meio de cooperação estratégica (SARAIVA, 2012). A aproximação com a Argentina, além disso, era crucial no que concerne à consolidação de uma sub-região de paz e de cooperação na América do Sul. Apenas a garantia de que outro país vizinho não poderia obter armas atômicas poderia, por fim, tranquilizar os tomadores de decisão brasileiros relativamente à decisão de aderir às instituições do regime internacional de não proliferação de armas nucleares.

O segundo Eixo, o Eixo Sul, comporta os demais países do Sul Global, com os quais o Brasil possui identidade internacional semelhante na condição de país em desenvolvimento. As relações próximas com países desse eixo se concretizavam na medida em que o Brasil deslocava sua política externa na direção do paradigma globalista (PINHEIRO, 2000; PECEQUILO, 2012) da política externa, o que implicou relações abrangentes com os demais países da comunidade internacional, em contraposição ao privilégio das relações com os Estados Unidos. Isso ocorreu, 
principalmente, no que se refere à política nuclear brasileira, entre 1979 e 1989, nos governos Figueiredo e Sarney.

Nesse período, grupos internos proponentes do desenvolvimento autônomo de tecnologia atômica fizeram uso das relações com países periféricos do sistema internacional para obter insumos necessários para viabilizar o programa nuclear paralelo. Isso ocorreu no caso da China, com a obtenção e urânio enriquecido, e com o México, no caso da tentativa de conseguir mercado consumidor para a tecnologia atômica teuto-brasileira. Também relevante foi a aproximação com o Iraque, no sentido de fornecer cooperação em tecnologia nuclear em troca de facilidades para obtenção de petróleo. Vale ressaltar que a relevância desse eixo foi breve, tornando-se pouco relevante, no que se refere à política nuclear, já no terceiro momento analisado (19901998), em especial devido à reaproximação ensejada com os países do Norte Global e à adaptação definitiva do Brasil ao regime internacional de não proliferação.

O terceiro eixo trata-se do Eixo Assimétrico, que comporta os países do Norte Global, com os quais o Brasil possui diferencial de poder no sistema internacional (LAFFER, 2004; RICÚPERO, 2006), em especial no que se refere à grande potência hegemônica do século XX, os Estados Unidos (RICÚPERO, 2006). Com Washington, o Brasil desenvolveu longa relação, afirmada desde o tempo de Rio Branco, na qual buscou obter insumos para o seu desenvolvimento. Essa busca de insumos foi operacionalizada, por exemplo, na implantação da usina de Volta Redonda e no reequipamento do exército brasileiro, quando da participação brasileira na Segunda Guerra Mundial (RICÚPERO, 2006), e intentada, no campo atômico, com o governo Médici, por meio do acordo firmado com a empresa Westinghouse.

No governo Geisel, porém, o Brasil passou a modificar a estratégia desenvolvida por Médici, no sentido de criar uma inflexão rumo à aproximação político-econômica com outras alternativas (LESSA, 1998), em especial na Europa Ocidental. Esses países europeus, em especial a Alemanha Federal, apresentam-se, junto com os Estados Unidos, como atores centrais no sistema internacional nas décadas de 1970, 1980 e 1990. São parte integrante do Norte Global (ROSA, 2015), porquanto comportavam, naquelas três décadas, o centro de um sistema internacional tripolar, baseado em "três pólos principais", qual sejam os Estados Unidos, a Europa Ocidental e o Japão (RICÚPERO, 1995: 111). Dessa forma, eles foram alternativas vislumbradas pelo governo brasileiro de Geisel para obter transferência de tecnologia nuclear de enriquecimento de urânio e de físsão atômica. 
O Eixo assimétrico pode ser caracterizado como aquele que comporta o conjunto de países com os quais o Brasil entende ter disparidade de pode e, assim, com os quais os principais atores que conduzem a política externa não mantêm semelhança no que concerne à formação de identidade semelhante. Isso ocorre porque esses países são percebidos como pertencentes a categorias de desenvolvimento socioeconômico e tecnológico distinto do brasileiro, o que, contudo, os tornaria parceiros relevantes para transferir tecnologia nuclear. Esse eixo foi especialmente relevante entre 1969 e 1978, quando, apesar da retórica discursiva avessa ao congelamento global de poder propugnado pelo TNP, o Brasil realizou tratativas com Estados Unidos, França, Alemanha Federal, Holanda e Inglaterra, no sentido de tentar obter transferência de tecnologia nuclear; e entre 1990 e 1998, quando a busca de inserir-se de maneira proativa no novo "momentum internacional" (HIRST, PINHEIRO, 1995: 6) e de obter vantagens na transferência de tecnologia dos países do Norte Global conduziu o Brasil a reaproximar-se do Eixo Assimétrico.

Em suma, como disposto pelo Diagrama 2, o qual ilustra a relação gráfica entre os três momentos da política nuclear e os três eixos definidos, argumenta-se nesta dissertação que a política nuclear brasileira passou, entre 1969 e 1998, uma mudança de estratégia caracterizada por duas transformações substantivas nos rumos da política nuclear, respectivamente na passagem dos governos Geisel para Figueiredo e de Sarney para Collor. Essas transições podem ser ilustradas por diferenças de ênfase na estratégia geral de obter a instalação no Brasil de tecnologia nuclear. Enquanto entre 1969 e 1978 o foco da estratégia externa de obter tecnologia nuclear fora nos países do Eixo Assimétrico, entre 1979 e 1989 os principais gestores da política nuclear resolveram voltar seus esforços para o desenvolvimento autóctone de tecnologia atômica, para o que ensaiaram aproximações eventuais com países do Eixo Sul. Entre 1990 e 1998, porém, o Brasil modificou novamente sua estratégia e ingressou, de fato, no regime internacional de não proliferação nuclear, o que somente foi possível devido à aproximação substantiva e a formação de cooperação estratégica com a Argentina, o Eixo Regional. 


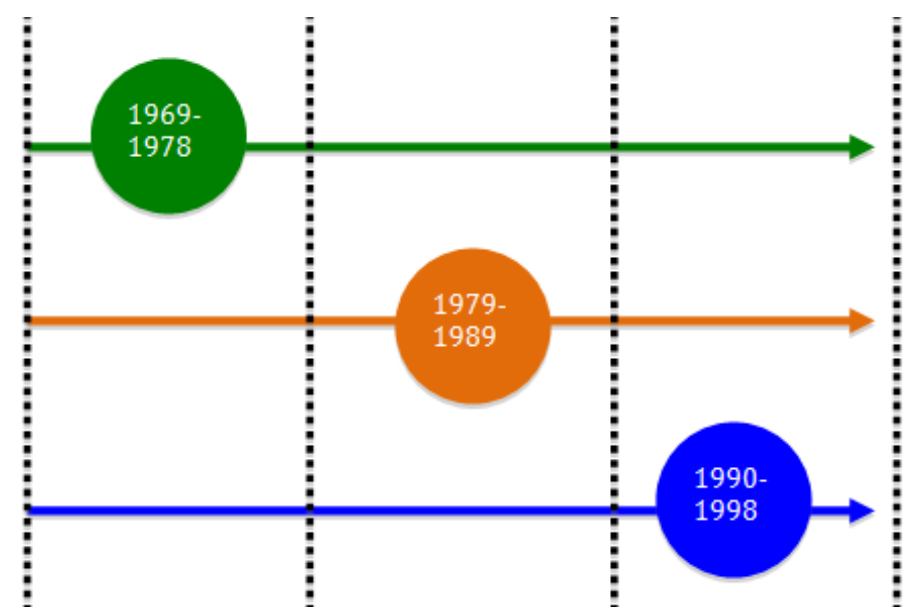

Legenda: Eixo Assimétrico; Eixo Sul; Eixo Regional.

Elaboração própria

Para melhor analisar as condições históricas que pautaram a busca brasileira por tecnológica atômica na segunda metade do século XX, esta dissertação divide-se em quatro capítulos, além desta introdução e da conclusão. O primeiro capítulo analisa a evolução e as principais diretrizes da posição oficial brasileira no que concerne à não proliferação de armas nucleares. Nesse, abordam-se os principais atores internos responsáveis pela condução da política nuclear nacional durante o período 1969-1998, com destaque para os diferentes papeis que esses atores exerceram no decorrer dos três momentos especificados, bem como se definem os princípios que guiaram a movimentação oficial brasileira em meio às instituições de não proliferação de armas atômicas.

O segundo analisa a prática da política nuclear brasileira no primeiro momento abordado, entre 1969, quando se iniciou o governo Médici e quando o Brasil repudiou, oficialmente, aderir ao TNP, até 1978, quando acaba o governo Geisel. Nesse capítulo, analisam-se os objetivos brasileiros de instalar no Brasil complexo nuclear para fins energéticos e se demonstra como essa estratégia se inseriu nas pretensões econômicas brasileiras, de modo amplo. Diferenciam-se, também, os meios utilizados por Médici e por Geisel para alcançar pelo desenvolvimento de tecnologia nuclear. Isso será feito por meio de análise detida às tratativas desenvolvidas em meio ao Eixo Assimétrico, com destaque para negociações com Estados Unidos, França, Alemanha Federal, Reino Unido e Holanda. 
O terceiro capítulo, por sua vez, aborda o período entre 1979 e 1989, que abrange os governos Figueiredo e Sarney. Nesse capítulo, dar-se-á atenção especial ao novo caminho verificado pela política nuclear com relação ao período anterior, no sentido de passar-se a enfatizar o desenvolvimento tecnológico de energia nuclear de modo autóctone. Esse processo de busca de tecnologia nuclear por meios próprios, que ensejou o programa nuclear autônomo, foi iniciado já no final do governo Geisel, quando, inclusive, as diretrizes gerais daquele programa foram definidas, contudo foi apenas em Figueiredo que essa nova estratégia foi, de fato, posta em prática. Especial ênfase é conferida a análise do programa paralelo e de como esse influiu no rumo da política nuclear brasileira e da movimentação internacional do Brasil, em especial no que se refere ao Eixo Sul. Também relevante é o processo de aproximação com o Eixo Regional, no qual se começa a delinear a cooperação estratégica.

O quarto capítulo, por fim, avalia os rumos da política nuclear durante o período 1990-1998. Esse período foi aquele no qual o Brasil adere, em definitivo, ao regime internacional de não proliferação nuclear, o que foi possível, argumenta-se, devido à única confluência de fatores verificada nesse período - a normalização das relações com o Eixo Regional, o que não se verificou no primeiro momento (1969-1978), e o interesse claro em obter tecnologia do Eixo Assimétrico, o que ficou pouco ocorreu no segundo momento (1979-1989). Para avaliar esse processo, esse capítulo aborda os rumos da política exterior do Brasil nos anos 1990, a institucionalização da cooperação estratégica com a Argentina e a reaproximação com o Eixo Assimétrico.

Por fim, a conclusão retoma os principais pontos abordados nos quatro capítulos anteriores e enfatiza a aplicabilidade dos três eixos bilaterais da política nuclear brasileira para o entendimento dos rumos do continuum da política nuclear nos três momentos selecionados (1969-1978; 1979-1989; 1990-1998). Será retomado a relevância do bom entendimento das relações bilaterais do Brasil para a compreensão dos rumos da política nuclear brasileira e será enfatizada a centralidade dos Eixos Assimétrico e Regional para a final adesão do Brasil ao regime internacional de não proliferação nuclear, na década de 1990. 
Capítulo 1.

\section{A Política Brasileira de Não Proliferação Nuclear: a perspectiva nacional de mundo, os atores e o discurso.}

\section{Introdução}

A definição da política nuclear é atividade grandemente influenciada pela visão de mundo dos atores internos desse país e pela maneira como esse país define sua identidade ante a comunidade internacional (LAFER, 2004). Cada país, inclusive aqueles do Sul Global, possui contribuições relevantes para a compreensão do sistema internacional e se movimenta globalmente segundo preceitos historicamente desenvolvidos por seu povo e cultura. O caso do Brasil não é diferente.

Para compreender o desenvolvimento da política nuclear brasileira, em âmbito oficial, é necessário analisar, previamente, os atores que desenvolveram a política nuclear brasileira segundo o desenvolvimento da visão brasileira de mundo. Esses dois elementos - o quadro geral e a política nuclear brasileira - serão desenvolvidos nas quatro seções deste capítulo. A primeira seção consta desta breve introdução, ao passo que a segunda desenvolve quadro dos principais atores responsáveis pela definição da política nuclear brasileira. A terceira parte explora as diretrizes da política nuclear brasileira e a última parte consta de conclusões parciais.

\section{Os Rumos da Política Nuclear Brasileira: os principais atores internos.}

A perspectiva brasileira para as Relações Internacionais parte de uma análise a qual se pode ser caracterizada como parte de uma visão do institucionalismo pragmático PINHEIRO, 2000), o que buscaria conciliar elementos de um entendimento hobbesiano do sistema internacional, marcado por elementos como a necessidade de sobrevivência internacional no ambiente anárquico, com aqueles de uma perspectiva grotiana, segundo a qual a ordem internacional se deve pautar em regras de direito internacional e instituições ${ }^{11}$ que protejam os Estados (GOFFREDO JR).

A visão de mundo brasileira abarca o modo como os principais atores internos entendem que o Brasil deve agir globalmente, de modo a obter os insumos necessários

\footnotetext{
${ }^{11}$ Por instituições internacionais, entende-se o "conjunto de tanto as organizações, estruturas físicas nas quais Estados participam com representantes, quanto o conjunto de normas, valores e regras que regem as relações entre Estados, criando ordem em meio à anarquia internacional" (SIMMONS; MARTIN, 2007: 192, tradução livre).
} 
para o desenvolvimento nacional. Apesar do papel certamente privilegiado que o Itamaraty exerceu na formulação da visão de mundo brasileira aplicada às relações internacionais (FONSECA JR, 1998), a política nuclear brasileira se formou a partir da influência de múltiplos atores distintos, do que, contudo, não decorreu inconsistência com aquilo que Amado Cervo (1994) denominou de princípios inerentes à política exterior brasileira, qual sejam, o pacificismo, o juridicismo e o realismo/pragmatismo.

Esse modo de atuação é guiado por princípios e normas que buscam sintetizar, para o ambiente externo, os valores nacionais, ao mesmo passo em que contribuem para manter certa uniformidade à política externa brasileira. Cada ator interno relevante, no caso aqui estudado, para a formulação e condução da energia nuclear, tem o relevante de papel de interpretar, por meio da análise que das da auto-identidade brasileira (FONSECA JR, 1998: 271), qual a melhor maneira de o país mover-se internacionalmente. Em suma, faz-se necessário, para compreender a política nuclear brasileira, entender tanto os elementos que conformam os acontecimentos históricos e as estruturas da sociedade internacional quanto entender o papel dos atores internos na interação com essas macroestruturas (DUROSELLE, 2000).

No que concerne à política pátria de energia e de não proliferação nuclear, os princípios da política externa brasileira adquirem especial relevância, porquanto informam a postura ativa do país no âmbito mundial. Essa postura seria, concomitantemente, contrária às disparidades globais de poder entre as potências e adepta do respeito às instituições internacionais vigentes. Além disso, propugnaria o direito de todos os Estados-Nação, ricos e em desenvolvimento, terem acesso a energia nuclear para usos pacíficos, porquanto todos os Estados são iguais juridicamente e, desse modo, detêm direito de acesso a insumos necessários ao desenvolvimento nacional. Esse processo, ocorreu por meio da interação de atores internos diversos, que se alternaram na função de fazer política, especialmente após a Guerra Fria, quando se notou avanço do interesse de grupos de pressão da sociedade civil e de outras agências burocráticas em temas de política internacional (FONSECA JR, 1998).

A política nuclear brasileira, em especial na sua vertente voltada à mobilização internacional e cooperação para transferência e desenvolvimento de tecnologia, nos eixos bilaterais Assimétrico, Sul e Regional, teve seu discurso modificado, ao longo do 
tempo, devido a mudanças tanto no contexto mundial e no regime internacional ${ }^{12}$ de não proliferação nuclear quanto pela mudança nas relações internas de poder.

Estas implicaram modificações na condução da política nuclear, ora voltando-a à busca de obter tecnologia advinda do exterior, pelo Eixo Assimétrico , especialmente Estados Unidos, França, Alemanha, ora voltando-a a esforços autóctones para obtenção de tecnologia nuclear, como ocorrido durante o período das administrações FigueiredoSarney. Essas breves mudanças no foco da política nuclear, em especial a virada rumo ao desenvolvimento nuclear autônomo, deram-se tanto devido a constantes desilusões relativas às possibilidades de obtenção de energia nuclear do exterior quanto devido a mudanças internas nos grupos de poder. Ambos os fatores estão intrinsecamente relacionados e serão analisados no capítulo 2.

No que concerne às mudanças internas de grupos políticos, vale destacar que, entre 1969 e 1998, o Brasil vivenciou mudanças significas de regime político e mudanças de elites no poder, os quais, contudo, não afetaram, de maneira uniforme, a política nuclear. Basta lembrar, inicialmente, que a mudança a qual se pode considerar a mais relevante no quase sócio-político brasileiro nos últimos anos, a redemocratização, em 1985, com a eleição indireta de Tancredo Neves, não afetou, de modo impactante, nem a política externa brasileira, porquanto se manteve aquilo que Amado Cervo (2009) denominou paradigma desenvolvimentista e que Celso Lafer (2004) denominou nacionalismo de fins; nem a política nuclear brasileira, como se demonstrará nos capítulos posteriores desta dissertação. Isso se deveu, entre outros fatores, à continuação, no regime democrático, do processo gradual de distensão política e de abertura (FAUSTO, 2012; HUNTER, 1997), delineado pela administração Geisel e consolidado pelo governo Sarney.

Verificou-se, dessa forma, no Brasil, a manutenção de certas diretrizes e políticas do regime militar durante a vigência do primeiro governo civil, eleito indiretamente. Conforme lembra Wendy Hunter (1997, p. 39), a transferência do poder aos civis implicou, no campo nuclear, garantia de manutenção da autonomia das forças armadas, conquistada durante do governo Figueiredo, em processo de desilusão com a

\footnotetext{
${ }^{12}$ Por regime internacional, entende-se "princípios implícitos ou explícitos, de normas, regras, decisão e procedimento sobre as expectativas de convergência dos atores num certo ramo das relações internacionais" (KRASNER, 1982, p. 187, tradução livre). Como opção teórica, optou-se aqui por utilizar esse termo de forma intercambiável com "instituições internacionais", que abrange o tanto as organizações, estruturas físicas nas quais Estados participam com representantes, quanto o conjunto de normas, valores e regras que regem as relações entre Estados, criando ordem em meio à anarquia internacional (Simmons; Martin, 2007).
} 
Alemanha iniciado nos momentos finais da administração Geisel. Essa autonomia implicava manter os recursos destinados à manutenção do complexo e estruturalmente difuso (BARLETTA, 1997: 6) programa nuclear autônomo, dirigido pela CNEN e implementado pelas três forças Armadas (BARLETTA, 1997; PATTI, 2014).

Mais importante que a redemocratização, foram dois eventos-chave no processo político nacional, que aqui neste de trabalho se os utiliza como pontos de transformação nos rumos da política nuclear: (1) a eleição de João Figueiredo para a Presidência da República, o que levou a processo de afastamento do marco cooperativo com a Alemanha Federal e ao fortalecimento dos grupos autonomistas nas Forças Armadas, na CNEN e no IPEN; (2) a eleição de Fernando Collor de Mello para o Planalto, o qual marcou o processo de desmantelamento consciente do programa nuclear autônomo e de adesão total ao regime internacional de não proliferação, modificado com o final da Guerra Fria e, como já mostrado, mais aberto aos países em desenvolvimento.

Essa breve exposição e a ênfase dada às mudanças políticas internas do Brasil com base nas mudanças ocorridas no Planalto demonstra o papel demasiadamente relevante que a Presidência da República exerce na condução dos assuntos de Estado. Foi ação ativa do Planalto, por exemplo, que possibilitou a constituição de instituições relevantes para a política nuclear brasileira, como o Acordo Brasil-Alemanha de $1975^{13}$ e a constituição da $\mathrm{ABACC}^{14}$. Isso seria, de fato, esperado, caso se considere o próprio processo de formação do Estado brasileiro, constituído sob a herança da burocracia portuguesa, altamente centralizadora (FAORO, 2001) e do sistema imperial altamente concentrado no monarca (CARVALHO, 2011), o qual implicou grande primazia e dilatação do Executivo no sistema político republicano.

A força da Presidência da República no sistema político brasileiro não implica ausência de outros atores relevantes para a definição dos rumos da política nuclear; pelo contrário, esses outros atores foram múltiplos e exerceram função altamente importante no que se refere à definição das estratégias nacionais para o campo nuclear. Dentre os principais atores que influíram na política nuclear brasileira, estacam-se agentes

\footnotetext{
${ }^{13}$ AA, 14. Fev. 1975. Segundo esse telegrama do Auswärtiges Amt, a viabilidade do acordo nuclear Brasil-Alemanha de 1975 e do acordo trilateral Brasil-Alemanha-AIEA, ambos de 1975, somente foram possíveis devido à ativa postura do presidente Geisel "em favor dos alemães" - Der brasilianische Präsident Geisel hat sich gegenüber Staatssecretär Sachs persönlich für diese Zusammenarbeit engagiert." (AA, 1975, p. 26).

${ }^{14}$ Conforme entrevista escrita concedida pelo inspetor Sílvio de Almeida ao autor, em 25/02/2016, "[eu] diria que [o que levou à formação da $\mathrm{ABACC}$ ] foram decisões que partiram diretamente dos Presidentes do Brasil e da Argentina. Um vez tomadas essas decisões, foram se implementando as ações decorrentes, [...] sob a orientação e cooperação do Itamaraty e [da] CNEN".
} 
vinculados a diversos órgãos da Administração Federal, empresas estatais binacionais e multilaterais e o Parlamento.

Esses atores, expostos no Quadro 1, possuíram diferentes papeis e relevância variada ao longo dos quase 40 anos que abarcam o período aqui estudado, oscilando desde agências protagonistas na condução da política nuclear brasileira, como a CNEN, durante todo o período, e organismos que perderam, gradualmente, seu poder de influência e de gestão, como a Nuclebrás, que, na década de 1980, teve sua relevância reduzida até ser, em 1989, transformada na Eletrobrás.

\section{Quadro 1 - Órgãos e agentes relevantes para a definição da política nuclear brasileira (1969-1998).}

\begin{tabular}{|c|c|c|c|c|}
\hline Órgãos & Vinculação & $\begin{array}{l}\text { Data de } \\
\text { Criação }\end{array}$ & $\begin{array}{l}\text { Data de } \\
\text { extinção }\end{array}$ & Observação \\
\hline A eronáutica & $\begin{array}{l}\text { Forças Armadas, vinculada } \\
\text { ao Ministério da Defesa, } \\
\text { desde } 1999\end{array}$ & 1941 & - & $\begin{array}{l}\text { Responsável, entre } 1979 \text { e 1989, pelo Projeto } \\
\text { Solimões. }\end{array}$ \\
\hline $\begin{array}{l}\text { Câmara e } \\
\text { Senado Federal }\end{array}$ & - & - & - & $\begin{array}{l}\text { Competência para ratificar tratados internacionais } \\
\text { nos quais a República Federativa do Brasil seja } \\
\text { parte (CF/88, art. } 49, \text { I); fiscalizar e controlar (...) } \\
\text { os atos do Poder Executivo, incluídos os da } \\
\text { administração indireta (CF/88, art. } 49, \mathrm{X}) \text {. }\end{array}$ \\
\hline CNEN & $\begin{array}{l}\text { Autarquia federal. } \\
\text { Vinuclada ao MCTI, desde } \\
1999 .\end{array}$ & 1956 & - & $\begin{array}{l}\text { “Órgão superior de orientação, planejamento, } \\
\text { fiscalização e pesquisa” (CARVALHO, 1980, p. } \\
\text { 13). Responsável pela coordenação do programa } \\
\text { nuclear paralelo. }\end{array}$ \\
\hline Eletronuclear & Empresa Estatal & 1997 & - & $\begin{array}{l}\text { Criada a partir da fusão da Eletronuclear com a } \\
\text { Diretoria Nuclear de Furnas. Subsidiária da } \\
\text { Eletrobrás }\end{array}$ \\
\hline Exército & $\begin{array}{l}\text { Forças Armadas, vinculada } \\
\text { ao Ministério da Defesa, } \\
\text { desde } 1999\end{array}$ & 1822 & - & $\begin{array}{l}\text { Responsável, entre } 1979 \text { e 1989, pelo Projeto } \\
\text { Atlântico. }\end{array}$ \\
\hline Furnas & $\begin{array}{l}\text { Empresa Estatal. Subsidiária } \\
\text { da Eletrobrás e vinculada ao } \\
\text { MME }\end{array}$ & 1957 & - & $\begin{array}{l}\text { Possuía poder de gestão e financeiro no setor } \\
\text { nuclear até } 1997 \text {, quando sua Diretoria Nuclear foi } \\
\text { transferida para a Eletronuclear. }\end{array}$ \\
\hline IPEN & $\begin{array}{l}\text { Vinculado ao Governo do } \\
\text { Estado de São Paulo e } \\
\text { gerido técnica e } \\
\text { administrativamente pela } \\
\text { CNEN. Associado à USP. }\end{array}$ & 1956 & - & $\begin{array}{l}\text { Associado à USP, é um instituto de pesquisa } \\
\text { responsável pelo desenvolvimento e estudo de } \\
\text { técnicas nucleares e de fontes alternativas de } \\
\text { energia. }\end{array}$ \\
\hline
\end{tabular}




\begin{tabular}{|c|c|c|c|c|}
\hline Marinha & $\begin{array}{l}\text { Forças Armadas, vinculada } \\
\text { ao Ministério da Defesa, } \\
\text { desde } 1999\end{array}$ & 1822 & - & $\begin{array}{l}\text { Responsável, entre } 1979 \text { e 1989, pelos Projetos } \\
\text { Ciclone e Remo. }\end{array}$ \\
\hline MME & Ministério & 1960 & - & $\begin{array}{l}\text { Ministério que gere a Eletrobrás e suas } \\
\text { subsidiárias. }\end{array}$ \\
\hline MRE & Ministério & 1822 & - & $\begin{array}{l}\text { Responsável pela condução das relações exteriores } \\
\text { do Brasil }\end{array}$ \\
\hline NUCLAM & $\begin{array}{l}\text { Empresa Binacional } \\
\text { (Nuclebrás é majoritária) }\end{array}$ & 1975 & 1988 & $\begin{array}{l}\text { Vinculada ao acordo Brasil-Alemanha (1975). } \\
\text { Dissolvida pelo Decreto No. 96.62, de 31/08/1988 }\end{array}$ \\
\hline NUCLEBRÁS & Empresa Estatal & 1971 & 1989 & $\begin{array}{l}\text { Criada na época da entrada e vigor do acordo de } \\
\text { cooperação com a Westinghouse. }\end{array}$ \\
\hline NUCLEI & $\begin{array}{l}\text { Empresa Binacional } \\
\text { (Nuclebrás é majoritária) }\end{array}$ & 1975 & 1988 & $\begin{array}{l}\text { Vinculada ao acordo Brasil-Alemanha (1975). } \\
\text { Dissolvida pelo Decreto No. 96.62, de 31/08/1988 }\end{array}$ \\
\hline NUCLEN & $\begin{array}{l}\text { Empresa Binacional } \\
\text { (Nuclebrás é majoritária) }\end{array}$ & 1975 & - & $\begin{array}{l}\text { Vinculada ao acordo Brasil-Alemanha (1975). } \\
\text { Transferida para FURNAS em } 1988 .\end{array}$ \\
\hline NUCLEP & $\begin{array}{l}\text { Empresa Binacional } \\
\text { (Nuclebrás é majoritária) }\end{array}$ & 1975 & - & $\begin{array}{l}\text { Vinculada ao acordo Brasil-Alemanha (1975). } \\
\text { Totalmente nacionalizada na década de } 1980 .\end{array}$ \\
\hline $\begin{array}{l}\text { Presidência da } \\
\text { República }\end{array}$ & - & 1889 & - & - \\
\hline SAE & $\begin{array}{l}\text { Secretaria vinculada à } \\
\text { Presidência da República }\end{array}$ & 1990 & - & $\begin{array}{l}\text { Órgão criado em } 1990 \text { que, entre outros efeitos, } \\
\text { abarcou o Serviço Nacional de Informações (SNI) } \\
\text { e parte da inteligência brasileira (HUNTER, 1997). } \\
\text { Foi reformulada durante a gestão Lula da Silva. }\end{array}$ \\
\hline
\end{tabular}

Fontes: Cooperação nuclear Brasil-República Federal da Alemanha - constituição de empresas subsidiárias na Nuclebrás, CPDOC, código 478592; Decreto No. 96.62, de 31/08/1988; CARVALHO, 1980; Hunter, 1997. Elaboração Própria.

Cabe lembrar que organizações expostas a seguir não se pretendem exaustivas dos órgãos que influíram nos rumos da política nuclear brasileira desde 1969; elas se apresentam, porém, como listagem relevante das principais organizações que influíram, ao menos, naquilo que concerne à condução da política nuclear brasileira em seu âmbito externo. São elas, além da Presidência da República, Ministérios (MME e MRE), agências e autarquias especializadas (IPEN, CNEN, NUCLEBRÁS, NUCLEI, NUCLAM, NUCLEP), Forças Armadas, Parlamento.

Ligados à Presidência da República, porquanto órgãos do Poder Executivo Federal, os Ministérios das Minas e Energia (MME) e das Relações Exteriores (MRE) apresentam-se como os principais ministérios na condução da política nuclear brasileira. O primeiro possui papel de destaque, porquanto é o responsável pela condução da política nuclear doméstica, e foi, especialmente, relevante no governo Geisel, 
especialmente devido à relevante função exercida pelo ministro Shigueaki Ueki, entre março de 1974 e março de 1979. Ueki muito influiu na condução das tratativas internacionais para obtenção de tecnologia nuclear junto a países como Alemanha e França, na postura brasileira de rejeitar assinar o $\mathrm{TNP}^{15}$, bem como na aproximação com o Iraque ${ }^{16}$. Apesar de, nos governos posteriores, o MME, no campo atômico, não se ter mantido tão relevante quanto o foi durante a gestão Ueki, esse continuou a trabalhar ativamente na condução da política nuclear brasileira, sempre se voltando, principalmente, de modo favorável a ações voltadas à obtenção de tecnologia energética nuclear do exterior ${ }^{17}$. Também relevante no que se refere ao MME é o seu papel na administração de empresas como a Nuclebrás e a Eletrobrás, por conseguinte das usinas nucleares de Angra I e II.

O segundo, o MRE, também possuiu papel de destaque na condução da política nuclear brasileira, em especial naquilo que concerne à obtenção de insumos internacionais para a obtenção de tecnologia nuclear. O papel do MRE e da diplomacia nos rumos da política nuclear brasileira, por meio de análise documental e de história oral, vem sendo, atualmente, estudado por pesquisadores como Carlo Patti e Matias Spektor, que vêm explorando as origens do programa nuclear brasileiro (PATTI, 2014) e da aproximação Brasil-Argentina nas décadas de 1980 e 1990 (MALLEA et al, 2015), com foco especial no governo Sarney.

A diplomacia foi especialmente relevante no que concerne à busca de recursos externos durante as gestões Médici, com os Estados Unidos, e Geisel, com a França e Alemanha. De fato, no governo deste ressalta-se como fator crucial a condução da pasta pelo ministro Azeredo da Silveira, quem acreditava ser o sistema internacional “fundamentalmente maleável para países como o Brasil” (SILVEIRA, 2010: 10). A diplomacia também foi basal no processo de aproximação com a Argentina durante a década de 1980 (MALLEA, 2012), sob a direção política pessoalmente orientada pelo presidente Figueiredo, e, na década de 1990, auxiliou a Presidência da República a conformar as instituições capazes de adaptar a política nuclear pátria ao regime internacional de não proliferação nuclear, como, por exemplo, o Tratado Quadripartite.

\footnotetext{
${ }^{15}$ MRE, 23 Fev. 1978

${ }^{16}$ MME, 17 Jan. 1979

${ }^{17}$ Em entrevista, José Goldemberg, ex-secretário da Ciência e Tecnologia no governo Collor, chegou a afimar que o Ministério de "o Minas e Energia sempre foi muito entreguista, entreguista entre aspas, entreguista no sentido mais amplo. Ele é populado por gente que não acredita na capacidade nacional, que está acostumada a fazer contratos com grandes empreiteiras, com grandes fintas, e que acha que antagonizar os Estados Unidos é a última coisa do mundo que a gente pode fazer" (GOLDEMBERG, 2010, p. 121).
} 
Foi no âmbito do discurso externo, em que o MRE tenha, talvez, exercido influência mais impactante, na medida em que conceitos formulados pela diplomacia foram sucessivamente adaptados à política nuclear. Entre esses conceitos, vale destacar a matiz de origem nacional-desenvolvimentista, a qual, principalmente desde o governo Kubistchek, por meio da adaptação de ideias de pensadores como Hélio Jaguaribe (LESSA, 2013), vislumbrava a necessidade de os países ricos apoiarem, mesmo monetariamente, projetos de desenvolvimento nos países emergentes.

Especialmente a partir da década de 1960, com a PEI, o discurso brasileiro em política nuclear passou a adquirir tom cada vez mais intimista e reivindicador, em movimento coetâneo com aquele seguido pela diplomacia. Nesse período, o Brasil, com a ativa participação do pensamento de Araújo Castro, adere integralmente ao discurso das injustiças no campo nuclear e do "congelamento de poder" (SARDENBERG, 2013 ; VARGAS, 2008) da ordem internacional pelo monopólio nuclear concedido pelo TNP às cinco potências nuclearizadas e membros do Conselho de Segurança das Nações Unidas $^{18}$.

Mais recentemente, na década de 1990, a noção de "pagamento das hipotecas devidas" e de renovação das credenciais do país por meio da adaptação do Brasil a posições propositivas nos grandes temas da agenda internacional (SALLUM JR, 2011), porém não sem abandonar a visão de mundo tradicional do Brasil, avessa às disparidades de poder material entre as nações que mantenham hierarquia injusta entre as potências ${ }^{19}$. Esse discurso de adaptação da política externa à ordem global pósGuerra Fria e de adesão a regimes internacionais como aquele de não proliferação nuclear foi continuado pelos governos Itamar Franco ${ }^{20}$ e Fernando Henrique Cardoso ${ }^{21}$, este último levando a cabo, junto com o $\mathrm{MRE}^{22}$, o processo de adesão ao TNP.

Além dos órgãos ministeriais, cabe ressaltar o papel primordial de agências especializadas no campo nuclear, em especial a CNEN e o IPEN. Essas agências, em especial a CNEN, podem ser consideradas as principais agências no campo da pesquisa

\footnotetext{
${ }^{18}$ São essas potências aquelas que conseguiram desenvolver capacidade nuclear de uso dual antes da assinatura do TNP, ou seja, antes de 1967: Estados Unidos, União Soviética (Rússia), Reino Unido, França, China.

${ }^{19}$ COLLOR, 24 set .1990

${ }^{20}$ FRANCO, 15 out. 1993

${ }^{21}$ CARDOSO, 1 jan. 1995.

${ }^{22}$ Segundo autores como Moniz Bandeira (2004, p. 142), o processo de adesão do Brasil ao TNP tratouse de um cálculo mais amplo, feito por Cardoso e Lampreia, sobre os rumos da política internacional, o qual levou em conta, especialmente, o processo de negociação da ALCA. Esses indícios serão melhor tratados no capítulo 4 desta dissertação.
} 
e gestão da energia nuclear, porquanto concentravam pessoal técnico especializado na pesquisa no campo nuclear. Elas tiveram especial impacto tanto na política nuclear brasileira quanto na política externa brasileira, na medida em que a aproximação entre cientistas brasileiros e argentinos permitiu a construção de confiança entre os países (WROBEL, REDRICK, 1998).

O papel dos cientistas, especialmente físicos do campo nuclear, ligados ou não a essas duas agências, foi, como lembram Paulo Wrobel e John Redrick (1998), foi imprescindível para a criação de medidas de segurança entre Brasil e Argentina, especialmente caso se considere à pouco usual constância política da CNEA argentina e sua aproximação com a CNEN brasileira. Isso foi possível, conforme lembra o inspetor da ABACC Sílvio de Almeida ${ }^{23}$, por meio da previsão de realizar "inspeções cruzadas", mesmo antes do projeto de criação da ABACC. Também relevante foi a participação de cientistas nucleares em outras áreas do governo, como o Dr. José Goldemberg no Secretaria de Ciência e Tecnologia do governo Collor (VELAZQUEZ, 2004, KASSENOVA, 2014).

O IPEN tratou-se de um instituto sediado na USP e que abarcou grande parte dos engenheiros e técnicos do setor nuclear treinados, em grande parte, nos Estados Unidos e na Alemanha. Esse instituto foi sumariamente importante no sentido de tentar adaptar ao Brasil o conhecimento advindo de outros países, porquanto, como lembrou o antigo direto da Companhia Energética de São Paulo, Joaquim Francisco de Carvalho (13 Nov. 1984, p. 6), as empresas brasileiras "não dispõem de departamentos de Pesquisa/desenvolvimento e engineering suficientemente aparelhados, para absorver, fixar e adaptar a tecnologia que se pretende transferir". Igualmente importante foi o papel do IPEN ao dispor o conhecimento técnico necessário para o desenvolvimento nuclear autônomo ${ }^{24}$, quando o diretor era Othon Pinheiro da Silva, particularmente para o programa da Marinha para a propulsão nuclear de submarinos, o Projeto Remo.

A CNEN, por sua vez, pode ser considerada um dos principais órgãos da gestão interna dos desenvolvimentos da tecnologia nuclear em solo brasileiro desde a sua criação, em 1956. Conforme lembrado pelo antigo diretor da CNEN no governo Figueiredo, Hervásio Guimarães de Carvalho (1980, p. 13), àquela comissão cabia ampla gama de atividades, que abarcava regulação; emissão de licenças; apoio a programas de graduação e pós-graduação em áreas como medicina, biologia; promoção

\footnotetext{
${ }^{23}$ Entrevista concedida ao autor em 25 fev. 2016.

${ }^{24}$ CIA, 8 set. 1986
} 
de intercambio técnico-científico; patrocínio da vinda de técnicos estrangeiros ao Brasil; atração de recursos privados para o desenvolvimento de energia nuclear no Brasil. Além disso, continua Carvalho

\begin{abstract}
“a CNEN, responsável perante os organismos internacionais, pelo controle do material radioativo e físsil, que tenha sido importado, ou mesmo produzido no país, tem como atribuições especificas a regulamentação da posse, uso, armazenamento e transporte de materiais radioativos, minérios nucleares e concentrados contendo elementos nucleares." (CARVALHO, 1980 p. 13)
\end{abstract}

Cabe assim destacar a abertura dada à CNEN para implementar atividades arroladas às relações internacionais, porquanto a esse órgão técnico foi confiado atuar junto a organismos internacionais, como a AIEA, no setor de contabilidade e controle de material radioativo. Essa prerrogativa da CNEN, bem como o corpo técnico que reuniu, influiu grandemente para torna-la um dos principais órgãos na gestão da política nuclear brasileira em especial a partir do governo Figueiredo, quando, sob a direção de Rex Nazaré Alves, a comissão gerenciou parte do programa nuclear autônomo (PATTI, 2014). Também relevante foi o papel da CNEN no processo de adesão do Brasil às instituições do regime internacional de não proliferação nuclear, por meio, por exemplo, da análise técnica da relação custo-benefício para a definição dos mecanismos previstos no Acordo Quadripartite ${ }^{25}$.

Ainda no campo da obtenção e desenvolvimento de energia nuclear, vale destacar o breve, porém relevante, papel desempenhado pela Nuclebrás, chefiada durante quase toda sua existência por Paulo Nogueira Batista, e pelas empresas binacionais firmadas sob o escopo do Acordo Brasil-Alemanha de 1975, a NUCLAM, a NUCLEI, a NUCLEN e a NUCLEP. A Nuclebrás foi criada ainda durante o governo Médici, em 1971, pela lei 5740 e tinha como função principal gerir as usinas nucleares a serem construídas em território nacional. A ela coube, inicialmente, gerir o processo de licitação e contratação de empresas estrangeiras capazes de vender ao Brasil reatores nucleares (SF, 1982: 169). Com a assinatura do Tratado Brasil-Alemanha de 1975, a Nuclebrás tornou-se sócia majoritária das quatro empresas constituídas sob o marco do acordo, portanto seria a natural receptora de know how, de métodos de gestão da energia nuclear e de engeneering (VON SIEMENS, 1979).

\footnotetext{
${ }^{25}$ Conforme afirmou o ex-presidente da CNEN José Luiz de Santana Carvalho, em entrevista concedida ao autor em 18 fev. 2016.
} 
O objetivo inicial da cooperação, não alcançado, era, como lembrou Peter von Siemens (1979), que, em 10 anos, pelo menos 80\% dos elementos necessários à construção de uma usina nuclear sejam assegurados por recursos locais, inclusive para o engineering, o que deveria ser possibilitado pela Nuclebrás. Durante a década de 1980, devido a mudanças internas já citadas no governo federal e a mudanças sistêmicas no regime de não proliferação nuclear, explicitados no capítulo 3, como os choques do petróleo, o arcabouço institucional mantido pela Nuclebrás começou a dar sinais de desgaste, à medida que os esforços nacionais foram direcionando-se o programa nuclear oficial para o autônomo.

Ainda considerando os atores que agiram para obter tecnologia nuclear, cabe destacar o papel exercido pelas três Forças Armadas no setor nuclear, em especial da Marinha, cuja atividade no campo pode ser traçada desde os primórdios da busca brasileira por tecnologia atômica, com as tratativas do Almirante Álvaro Alberto junto à comunidade internacional, até o atual programa de cooperação com a França para construção de submarino a propulsão nuclear.

As Forças Armadas, as quais estiveram no comando do Brasil entre 1964 e 1985, no chamado Regime Civil-Militar, mantiveram certa regularidade em suas posições sobre a política externa, marcada, como lembra Thiago Gehre (2012, p. 113), por “preocupações geopolíticas, [pel]a 'paranóia' de Guerra Fria e [pel]a doutrina nacional de segurança" baseada na lógica da geopolítica golberiana. Esses três fatores, continua Gehre, "produziram um vetor dominante do pensamento dos militares brasileiros [...], o que gerou uma esquizofrenia tridimensional entre ideologia, o discurso e a ação, todos relacionados aos meios para a consecução da política externa brasileira”. Isso significou uma atuação constante dos militares brasileiros no campo externo focada na busca de constituição de interesses nacionais relacionados à defesa do Brasil e ao desenvolvimento nacional (FONSECA JR, 1998), o que, particularmente no Governo Médici, pode ser relacionado ao projeto "Brasil Potência", retomado, em certa medida e sobre outro viés, por Collor, com seu projeto de incluir o Brasil entre os países do "primeiro mundo" (CASARÕES, 2012).

Apesar do discurso ideologizado e das perspectivas de guerra vislumbradas pela Escola Superior de Guerra de guerras externas ${ }^{26}$, a ação externa do Brasil seguiu

\footnotetext{
${ }^{26}$ Seriam três as hipóteses de guerra vislumbradas pela ESG durante o Regime Militar: (1) envolvimento em guerra extracontinental; (2) conflito regional com a Argentina ou com uma aliança de países limítrofes; (3) guerra revolucionária e anti-guerrilhas (GEHRE, 2012). A segunda hipótese foi substituída
} 
diretrizes voltadas, majoritariamente, à obtenção de recursos externos ao desenvolvimento, em atitude não abertamente belicista, mas ligada à busca do "fortalecimento do poder nacional [...] estruturado nas suas quatro expressões: política, econômica, militar e psicossocial" (GARCIA, 1997: 27). Certa corrida armamentista no campo nuclear teria sido perseguida com maior ênfase, somente, no governo Figueiredo (LEALI; MALTICHIK, 2014).

Os militares podem ser considerados como grupo social abrangente e marcado pela coexistência de diferentes correntes de pensamento, como a clássica divisão entre sorbonistas e linha-dura e a divisão entre os "entreguistas" e "nacionaldesenvolvimentistas", que também se estendeu a analises relativas ao congresso nacional a partir da Segunda República. Para os efeitos da política nuclear, destacam-se aqui dois grupos nas Forças Armadas, ambos ligados, de forma majoritária, à vertente do desenvolvimentismo: o grupo que aqui chamamos de autonomistas belicistas e aquele dos não belicistas.

O primeiro grupo, ilustrado por meio de diretrizes expostas em notas manuscritas feitas pelo antigo diretor da Nuclebrás, Paulo Nogueira Batista ${ }^{27}$, nas quais ele cita posição de militares favoráveis à construção de artefato nuclear bélico pelo Brasil, justificada pelo estágio avançado do programa nuclear argentino e por temores externos, como possível conflito com potências estrangeiras (e.g. Suez, em 1956, Guerra das Malvinas, entre abril e junho de 1982). Para esse grupo, armamentos nucleares seria meio para manter o prestígio e a autonomia brasileira no ambiente internacional, anseio este que consta como diretriz básica e constante na atuação externa do Brasil (SARAIVA, 2014), além de marca característica da busca da defesa da autoidentidade nacional (FONSECA JR, 1998). Esse primeiro grupo foi especialmente relevante no governo Figueiredo ${ }^{28}$, tendo-se mantido no decorrer dos anos iniciais da administração Sarney, e foi um dos principais atores responsável pela constituição do Programa Nuclear Autônomo ${ }^{29}$.

O segundo grupo trata dos militares que, mesmo enfatizando a necessidade de desenvolvimento nacional e de autônoma, não consideravam a necessidade de desenvolvimento de artefatos bélicos, devido, por exemplo, aos custos financeiros que

\footnotetext{
, a partir da Guerra das Malvinas, progressivamente abandonada pelos militares e substituída por conflito possível com os Estados Unidos (KASSENOVA, 2014; MONIZ BANDEIRA, 1989)

${ }^{27}$ BATISTA, sem data; BATISTA, 11 jun. 1975

${ }^{28}$ CIA, 21 out. 1983

${ }^{29}$ CSN, 21 fev. 1985
} 
esse projeto poderia acarretar ao Brasil $^{30}$ e à possibilidade de restrição do acesso a tecnologia sensível via cooperação internacional. Esse grupo, que buscava obter tecnologia nuclear principalmente por meio de cooperação com países do Eixo Assimétrico e que baseava sua análise, principalmente, em considerações de caráter energético e imediato, foi especialmente relevante nos governos Médici e Geisel.

O poder de influência política de ambos os grupos militares foi-se reduzindo a partir do governo Collor (HUNTER, 1997), o que é corroborado, por exemplo, pela criação, pelo decreto 99.373/90, da Secretaria de Assuntos estratégicos, que passaria a abarcar parte do Serviço Nacional de Informações (SNI) e a qual coube implementar o "programa de desenvolvimento de tecnologia no campo nuclear" (COLLOR, 1991: 76). Esse processo de perda do poder de influência dos militares consolidou-se pela concepção, em 1999, por meio da Lei Complementar No 97, de 1999, do Ministério da Defesa; e pela concomitante extinção do Estado Maior das Forças Armadas.

Um último ator relevante a ser analisado é o Parlamento, cuja relação com atores do Executivo na condução da política externa é alvo de debate teórico (MARTIN, 2000). No caso brasileiro, a CF/88 atribuiu ao Congresso relevantes competências na condução da política externa, como a ratificação de tratados internacionais, pelo artigo 49, I, e o controle e fiscalização dos atos do Poder Executivo, artigo 49, X. Particularmente no que concerne ao uso dessas competências em assuntos relacionados à cooperação internacional e à política externa, a atitude padrão do Congresso brasileiro, notadamente a partir de 1988, seria, conforme lembrou Cristina Alexandre (2007, p.1), como um "alarme de incêndio", atuando após grande repercussão de determinado assunto na opinião pública. Isso significa que haveria aceitação tácita do Legislativo das atitudes do Executivo em questões relativas à política externa, em parte, atribuídas à competência do MRE, mas também à falta de interesse do eleitorado brasileiro em temas internacionais (NEVES, 20003) e ao quase desprovimento do Itamaraty de “verbas e 'vagas' para distribuir entre as 'clientelas' (eleitorais e de outras espécies)" (ARBILLA, 2000: 345).

No caso da política nuclear, o Parlamento, Câmara dos Deputados e Senado Federal, foi ator fundamental e histórico na definição da política nuclear brasileira desde seus primórdios, especialmente entre 1953 e 1960 (PATTI, 2014a). No que concerne ao período entre 1969 e 1998, esse ator tornou-se especialmente relevante a partir da

\footnotetext{
${ }^{30}$ BATISTA, sem data
} 
década de 1980, de modo quase concomitante ao processo de abertura política ${ }^{31}$, porém ainda em meio ao regime civil-militar. Em 1978, o Senado Federal instaurou Comissão Parlamentar de Inquérito (CPI) para tratar do tema da questão nuclear, tendo como justificativa avaliar as supostas irregularidades no programa nuclear brasileiro e no Acordo Brasil-Alemanha de 1975 expostas por artigo publicado na revista alemã Der Spiegel $^{32}$. Essa CPI, a qual tratou extensivamente do programa nuclear brasileiro e da cooperação com a Alemanha Federal, apresentou importantes resultados materiais sobre o caráter da cooperação desenvolvida pelos governos Médici e Geisel e, ao final, mostrou-se favorável à política brasileira, além de considerar sensacionalistas e desfundadas as alegações feitas pela revista alema ${ }^{33}$. Após a divulgação, pelo presidente Sarney, em 1987, da existência do Programa Nuclear Autônomo, o Congresso Nacional instituiu, em 1990, Comissão Parlamentar Mista de Inquérito (CPMI) destinada a apurar esse programa. Essa CPMI também criou, em 1990, a Comissão Mista Permanente para Assuntos Energéticos e Nucleares, cuja manutenção não perdurou.

Apesar da importância do Congresso Nacional naquilo que se refere ao apuramento do programa nuclear brasileiro por meio de comissões de inquérito, o papel que pode ser considerado mais importante do parlamento brasileiro em assuntos nucleares foi o da definição de diretrizes gerais da política nuclear brasileiro quando da formulação da CF/88, pela Assembleia Nacional Constituinte. Esse processo, o qual contou com o já descrito intenso lobby de grupos favoráveis e contrários ao uso da energia nuclear, levou a texto restritivo sobre o uso da energia, o qual consagrou o caráter pacifista da política nuclear brasileira, ao definir, no artigo 21, XXIII, a., que "toda atividade nuclear em território nacional somente será admitida para fins pacíficos e mediante aprovação do Congresso Nacional”. Também relevante foi aquilo previsto no artigo 49, XIV, segundo o qual se definiu como "competência exclusiva do Congresso Nacional (...) aprovar iniciativas do Poder Executivo referentes a atividades nucleares".

Esses dois dispositivos $\mathrm{CF} / 88$ demonstram interesse do Legislativo, por meio da Assembleia Constituinte, de garantir à comunidade internacional e à opinião pública pátria a opção pacifista da política externa brasileira e de seu programa nuclear.

\footnotetext{
${ }^{31}$ O processo de abertura política no governo Figueiredo pode ser exemplificado por duas regras: a Lei No 6.767/79, a qual reestruturou o sistema político brasileiro, pela via da instituição do sistema multipartidário; a Lei No 6.683/79, que definiu anistia ampla, geral e irrestrita a perseguidos políticos e agentes governamentais.

${ }^{32} \mathrm{SF}, 1982$, p. 03

${ }^{33} \mathrm{SF}, 1982$, p. $03-04$
} 
Conquanto abrangentes e precisos, esses dispositivos constitucionais também representaram, como lembra Michael Barletta (1997, p. 19, tradução livre), certa vitória de grupos apoiados pelo lobby militar, na medida em que não "ab-rogaram explicitamente o direito de os militares desenvolver explosivos nucleares pacíficos ou de enriquecer urânio fora das salvaguardas internacionais, e não estabeleceram mecanismos para implementar a supervisão civil”. Esses pontos foram, especificamente, tratados no governo Collor, quando o Brasil assumiu a opção pacífica de seu programa nuclear e abandonou a tese das explosões pacíficas, abordadas no capitulo 3.

\section{Princípios e diretrizes da Política Nuclear Brasileira}

Esses atores, supradefinidos, definiram os rumos da política nuclear brasileira levando em consideração elementos advindos de dois níveis de análise, o externo - o ambiente internacional e os do regime global de não proliferação nuclear -, e o interno os desenvolvimentos políticos domésticos. Essas definições ocorreram com base no pano de fundo do "acumulado histórico" da política externa brasileira (CERVO, 1994: 26), o qual imprimiu às ações brasileiras princípios e valores únicos e historicamente constituídos, como o juridicismo, o pacifismo, o realismo/pragmatismo ${ }^{34}$.

A relevância de cada um desses atores no quadro geral do processo de formação da política nuclear nacional variou ao longo tempo, de modo que também variassem as leituras feitas das diretrizes gerais da política nuclear brasileira. Por exemplo, ao passo que, no período 1969-1978, os grupos militares não belicistas, o MME e o MRE detiveram maior relevância na política externa, portanto imprimiram maior ênfase à cooperação com o Eixo Assimétrico das relações bilaterais e à necessidade de rápida obtenção de tecnologia nuclear; entre 1979 e 1989, a ascensão de grupos militares ligados a setores desenvolvimentistas bélicos moveu a política do país para intensificação do discurso autonomista e para a aproximação com países do Eixo Sul.

No período 1990-1998, por fim, a consolidação da democracia e a ascensão de grupos civis contrários à obtenção de tecnologia nuclear para fins múltiplos e favoráveis á integração do Brasil no regime internacional de não proliferação, tanto no Parlamento

\footnotetext{
${ }^{34}$ Segundo Cervo (1994: 27) o realismo converteu-se em pragmatismo com o decorrer do tempo. "O pragmatismo induz a adequação das percepções dos reais interesses nacionais aos desígnios externos, de forma a fazer prevalecer o resultado sobre o conceito, os ganhos concretos e materiais sobre os valores políticos ou ideológicos, a oportunidade sobre o destino, a liberdade de ação sobre o empenho do compromisso, o universalismo sobre as camisas-de-força dos particularismos, a aceitação sobre a resistência dos fatos".
} 
quanto no campo dos institutos de pesquisa, Presidência e Ministérios, levaram o Brasil a modificar sua prática, de modo a admitir que autonomia e desenvolvimento poderiam ser obtidos aderindo-se, gradualmente, àquele regime. Foi esse período aquele de abandono da autonomia pela distância (FONSECA JR, 1998) e de aceitação da possibilidade de ingresso do Brasil nos regimes internacionais definidos pelas comunidade internacional. Isso seria feito, contudo, mantendo-se as especificidades brasileiras, de um país que, apesar de fazer parte do grande bloco capitalista da Guerra Fria, sempre se caracterizou como um "Outro Ocidente" (LAFER, 2004: 76), devido à seu também pertencimento ao grupo dos países em desenvolvimento.

Apesar das mudanças de ênfases, algumas diretrizes da Política Nuclear Brasileira mantiveram-se constantes no longo prazo. Essas diretrizes são interpretadas como decorrência de dois anseios gerais da movimentação internacional do Brasil: o desenvolvimento, o verto síntese da movimentação internacional do Brasil (CERVO, 1994); a autonomia (FONSECA JR, 1998; VIGEVANI et al, 2003; SARAIVA, 2014). A autonomia é entendida, no decorrer da prática histórica da diplomacia brasileira, não como isolamento ou afastamento da política internacional, mas como um aspecto social da negociação internacional, muito relacionado à procura brasileira por mover-se internacionalmente livre de constrangimentos externos (SARAIVA, 2014). Trata-se, portanto, de autonomia decisória, a qual se relaciona, de modo intrínseco, tanto com a responsabilidade de a diplomacia refletir os interesses nacionais, de maneira ampla, quanto com a ideia de nacionalismo de fins ${ }^{35}$.

Dessa forma, autonomia não implica afastamento dos países desenvolvidos, mesmo porque isso implicaria condenação do país "ao atraso e à vulnerabilidade" ${ }^{36}$. Esse conceito foi influenciado pelo pensamento de estudiosos como Araújo Castro, o qual consagrou a postura de brasileira de tentar encontrar posições independentes ante a divisão bipolar da Guerra Fria (RESENDE, 2009). Esse constante “desejo de autonomia" (PINHEIRO, 2000) foi, constantemente, reestudado pela academia, em meio à qual se desenvolveram conceitos síntese de formas específicas de o país perseguir a autonomia decisória, como os conceitos de "autonomia na distância"

\footnotetext{
${ }^{35}$ Segundo Celso Lafer (2004: 88-89), nacionalismo de fins é processo no qual as linhas mestras da política externa "se traduziram em trabalhar as modalidades possíveis de uma integração controlada na economia mundial, mobilizando recursos para aprofundar o processo de substituição de importações (...). Traduziu-se, também, num esforço de construir o espaço da autonomia nacional por um moderado e relativo distanciamento - maior ou menor, dependendo das condições de permissibilidade (...) dadas pela dinâmica política internacional - em relação aos pólos de poder do eixo assimétrico das relações internacionais do Brasil".

${ }^{36}$ SARNEY, 13 Mai. 1987
} 
(FONSECA JR, 1998) e "autonomia na integração" (VIGEVANI et al, 2003). As formas diferentes de autonomia implicavam coadunar condicionantes estruturais com os conceitos básicos da política externa, inicialmente por meio da tentativa de "manter uma distância em relação às ações do Bloco Ocidental, sobretudo quando significavam engajamentos militares" (FONSECA JR, 1998: 362).

O desenvolvimento, por sua vez, apesar de presente como característica presente na política externa brasileira desde os primórdios do Estado-Nação, ganhou maior ênfase na ação estatal a partir da década de 1930, com o estabelecimento daquilo que Amado Cervo (2009) denominou de paradigma desenvolvimentista, ou seja, o modo de atuação pelo qual o Estado brasileiro assume a condição de agente primordial do desenvolvimento nacional, pela via da administração pública e das empresas estatais. A despeito de o paradigma desenvolvimentista se ter modificado na década de 1990 e na década de 2000, em especial com o abandono do "nacionalismo de fins" (LAFER, 2004), a noção de buscar, no exterior, insumos para promover o desenvolvimento nacional manteve-se como constante no discurso externo pátrio, inclusive no campo nuclear, entendido como meio inexorável para consolidação de matriz energética capaz de sustentar o crescimento econômico nacional.

Também importante para compreender a noção de desenvolvimento exposta pelo discurso nacional é a influência exercida nos tomadores de decisão nacionais pela teoria da dependência (LÓPES-ALVES, 2010; TICKNER, 2003). Dentre as múltiplas vertentes dessa teoria, destaca-se, no Brasil, aquela baseada no pensamento cepalino, a qual propugna divisão centro-periferia das relações internacionais nociva para os países periféricos, devido à deterioração dos termos de troca dos produtos primários. Esse pensamento foi notadamente relevante, no Brasil, no final da segunda república (19491964), com a influência de nomes como Celso Furtado, e na Terceira República (1985-), com Fernando Henrique Cardoso.

Ao incitar os países periféricos a se modernizarem industrialmente para quebrar a dualidade centro-periferia, a teoria da dependência também contribui para que os países latino-americanos, em especial o Brasil, assumam postura internacional mais ativa (TICKNER, 2003) e global, com o objetivo de sair da esfera de dependência dos países do Norte Global. Nesse sentido, destacam-se a busca de parcerias internacionais diversas no ambiente internacional pelo governo brasileiro quando dos governos da República Liberal, dos generais Emílio Médici, Ernesto Geisel, João Figueiredo, e dos governos dos presidentes Itamar Franco, Fernando Henrique Cardoso, Luiz Inácio Lula 
da Silva. Essa busca de parcerias deu-se, em especial, no que se refere à procura de alternativas os Estados Unidos para a obtenção de tecnologia de ponta (LESSA, 2013; LESSA, 1995), ou a substituição do paradigma americanista pelo globalista (PINHEIRO, 2004). No caso nuclear, isso ensejou os acordos de cooperação nuclear firmados com a com a República Federal da Alemanha, em 1974 e 1975, e as tratativas com os países do Eixo Sul, entre 1979 e 1989.

A busca de autonomia e de desenvolvimento, guias da política externa brasileira, imprimiu à vertente externa da política nuclear brasileira atuação própria, baseada em certas diretrizes que marcaram, em especial, o discurso nacional e que justificaram as tratativas brasileiras junto à comunidade internacional no campo atômico e da não proliferação. Essas diretrizes, cuja aplicação modificou-se no decorrer do período entre 1969 e 1998, podem ser sintetizadas em quatro, as quais tratam do modo como os atores nacionais direcionaram a busca brasileira por desenvolvimento e autonomia no campo nuclear, embasando-se para isso na perspectiva de mundo nacional. Essas diretrizes, bem como os principais princípios da visão de mundo nacional que as motivaram, estão explicitadas no Quadro 2, o qual sintetiza as principais linhas da política nuclear brasileira e as relaciona com os princípios formadores do arcabouço histórico da política externa brasileira

Quadro 2 - Diretrizes da vertente externa da política nuclear brasileira.

\begin{tabular}{|c|c|c|c|}
\hline & Diretriz & $\begin{array}{l}\text { Princípio justificador, na } \\
\text { visão de mundo brasileira }\end{array}$ & Exemplo de ações práticas. \\
\hline 1 & $\begin{array}{l}\text { Busca de normas justas e benéficas aos } \\
\text { países periféricos. }\end{array}$ & jurisdicismo & Recusa brasileira em assinar o TNP \\
\hline 2 & $\begin{array}{l}\text { Busca do acesso equânime de toda a } \\
\text { comunidade internacional ao } \\
\text { desenvolvimento de tecnologias } \\
\text { essenciais ao desenvolvimento. }\end{array}$ & Jurisdicismo; pacifismo & $\begin{array}{l}\text { Cooperação com a Alemanha Federal e com o } \\
\text { Iraque. Aproximação com a Argentina no } \\
\text { campo nuclear. }\end{array}$ \\
\hline 3 & $\begin{array}{l}\text { Busca de cooperação internacional que } \\
\text { permita o acesso mais amplo de toda a } \\
\text { humanidade a condições de } \\
\text { desenvolvimento. }\end{array}$ & pragmatismo & $\begin{array}{l}\text { Aproximação dos conceitos de não proliferação } \\
\text { nuclear com aquele de proteção ambiental e de } \\
\text { combate à pobreza. }\end{array}$ \\
\hline 4 & $\begin{array}{l}\text { Busca de ambiente internacional } \\
\text { seguro e pacífico. }\end{array}$ & Pacifismo & $\begin{array}{l}\text { Conformação de zonas livres de armamentos } \\
\text { nucleares na América Latina (Tratado de } \\
\text { Tlatelolco) e no Atlântico Sul (ZOPACAS). } \\
\text { Posterior assinatura do TNP. }\end{array}$ \\
\hline
\end{tabular}

Elaboração Própria. 
A primeira diretriz refere-se à busca de normas e regras justas e benéficas aos países periféricos. Trata-se de reflexo do jurisdicismo da perspectiva de mundo brasileira, pois parte do pressuposto de que todos os Estados são iguais juridicamente, logo devem respeitar regras que sejam justas e benéficas a todas. Essa diretriz relacionase, diretamente, à critica ao "congelamento de poder" entre as superpotências, de Araújo Castro, e à política de poder entre as nações (VARGAS, 2009; RESENDE, 2009) e foi uma das justificativas para a não adesão do Brasil ao TNP, considerado não benéfico e discriminatório pelo Brasil ${ }^{37}$. De fato, o TNP é considerado, pelo Brasil, como instrumento para manutenção de hierarquização injusta do sistema internacional.

Como afirmou o general Danilo Venturini ${ }^{38}$, citando Mário Pessoa, em depoimento à CPI do programa nuclear, em 1990, o TNP poderia ser considerado um "Tordesilhas Nuclear", porquanto dividiu o mundo em dois grupos de países - aqueles com "dependência tecnológica" e aqueles com domínio da tecnologia atômica. Desse modo, ao não aderir ao TNP, o Brasil teria preservado "o seu direito a um acesso sem restrições, em bases não discriminatórias, a todas as tecnologias necessárias ao uso autónomo da energia nuclear para fins exclusivamente pacíficos" ${ }^{\text {,39 }}$. A aversão ao TNP foi gradualmente eliminada entre 1990 e 1998, quando o Brasil aderiu, progressivamente, ao regime interancional de não proliferação nuclear; contudo cabe salientar que o país manteve as críticas feitas àquele tratado. A mudança se deu, basicamente, no âmbito dos meios para se atingir o objetivo: enquanto a estratégia de autonomia pela distância implicava criticar, de longe, o caráter prejudicial do TNP, a estratégia de Cardoso, da autonomia pela integração (VIGEVANI et al, 2003), implicava adesão completa aos regimes internacionais, de modo a poder neles influir de forma efetiva, uma vez participando de sua condução.

A segunda diretriz, também relacionada ao jurisidicismo e à visão grotiana de mundo do Brasil, trata da busca do acesso equânime de toda a comunidade internacional a tecnologias essenciais ao desenvolvimento, dentre as quais a atômica. Diferentemente da primeira diretriz, que foca no regime internacional e nas instituições de não proliferação nuclear, essa diretriz enfoca o caráter multifacetário do desenvolvimento, que não adviria apenas de normas e regras, mas também de conformação de meios econômicos e políticos capazes de garantir o desenvolvimento. Isso é ilustrado pela

\footnotetext{
${ }^{37}$ SILVEIRA, 2 abril 1974

${ }^{38} \mathrm{CN}, 1990$, p. 12

${ }^{39}$ BATISTA 11 nov. 1980 , p. 3
} 
definição do presidente Itamar Franco do desenvolvimento como um "processo de difusão do progresso técnico" 40 , ou seja, como decorrência da acesso desimpedido "mesmo que em bases comerciais" às tecnologias de ponta.

A terceira diretriz, relacionada ao princípio do pragmatismo da atuação brasileira no exterior, trata da busca de cooperação internacional que permita acesso mais amplo de toda a humanidade a condições de desenvolvimento. Essa cooperação com outros países parte também do pressuposto de que o desenvolvimento, interesse nacional brasileiro, é algo multifacetado e abrangente, logo deve envolver distintos temas e políticas (CERVO, 1994; FONSECA JR, 1998). Na prática e discurso brasileiros, essa busca de cooperação multifacetada envolvendo o campo nuclear foi diversas vezes intentada pelos Presidentes da República e pelos principais atores definidores da política nuclear brasileira, seja pela definição das armas nucleares como desperdício de gastos que poderiam ser mais bem utilizados em ações de combate à "forme, à doença, à ignorância e à miséria" ${ }^{, 41}$, seja na relação entre o desarmamento e a responsabilidade de os países desenvolvidos transferirem tecnologias limpas à periferia ${ }^{42}$.

A quarta e última diretriz propugna a busca de ambiente internacional seguro e pacífico, portanto favorável à autonomia e ao desenvolvimento nacional. Essa diretriz apresenta-se como abrangente o suficiente para embasar, praticamente, toda a ação brasileira no campo da não proliferação nuclear, pois parte do pressuposto de armas nucleares são inseguras e ameaçam a estabilidade global. Dessa forma, cabe às nações do mundo incentivar mecanismos eficazes de não proliferação nuclear horizontal e vertical, de modo que essas armas sejam extirpadas. Essa diretriz tornou-se mais intransigente ao longo da década de 1990, com o abandono da tese da existência de explosivos nucleares para fins pacíficos, e a consequente generalização da repreensão brasileira a todo e qualquer explosivo nuclear.

Essas quatro diretrizes delimitam o modo como o Brasil, no âmbito oficial, justificou suas ações no campo da não proliferação nuclear. Apesar de, como visto nos capítulos posteriores, essas diretrizes nem sempre terem sido verificadas na prática, elas são essenciais para a definição da mobilização internacional do Brasil em meio às instituições internacionais de não proliferação nuclear.

\footnotetext{
${ }^{40}$ FRANCO, 15 out. 1993

${ }^{41}$ SARNEY, 23 set. 1985

${ }^{42}$ COLLOR, 24 set. 1990; CN, 1990, p. 13
} 


\section{Conclusões parciais}

A política nuclear brasileira, em especial sua vertente externa, é decorrência do entendimento dos atores que a conduzem sobre a identidade nacional e sobre os interesses brasileiros no ambiente externo. Essa perspectiva, pautada por princípios delimitados, como o jurisdicismo, o pacifismo e o pragmatismo, influiu no modo como os atores internos entendem que o país deva mover-se ante as instituições internacionais de não proliferação nuclear. Esses atores, múltiplos e variados, atuaram com certa homogeneidade, ao menos no nível oficial, porquanto suas interações e leituras dos rumos do regime internacional de não proliferação nuclear permitiram a conformação de quatro diretrizes básicas da política nuclear brasileira no âmbito internacional.

Por meio dessas diretrizes, os atores internos vislumbraram a possibilidade de utilizar o regime internacional de não proliferação atômica e a política nuclear nacional como mecanismos para possibilitar o desenvolvimento nacional e a autonomia decisória. A forma especifica como essa postura oficial delineada neste capítulo foi operacionalizada e confrontada com diferentes interesses nacionais é explorada nos capítulos posteriores. 
Capítulo 2.

\section{A Implementação do Complexo Nuclear Brasileiro (1969-1978): a primazia do Eixo Assimétrico da Política Nuclear brasileira.}

\section{Introdução}

A busca da diversificação das fontes enérgicas da matriz nacional é tema patente na política externa brasileira desde, pelo menos, os primórdios do século XX. Apesar de a tecnologia atômica ter sido objeto de desejo dos brasileiros desde o início a Segunda República, como ilustrado pelos esforços ensejados pelo almirante Álvaro Alberto (PATTI, 2014a), no sentido de obter transferência de tecnologia nuclear para o Brasil ${ }^{43}$, foi, apenas, no regime militar que o país conseguiu implementar, em território pátrio, meios para controlar o ciclo do átomo.

Em especial a partir da década de 1970, motivado por constrangimentos de ordem tanto internacional quanto doméstica, o governo brasileiro instaurou processo de renovação do setor energético nacional, o qual teve como uma de suas prioridades a consolidação da presença nuclear na matriz enérgica. Esse esforço foi iniciado na administração Médici, por meio de tratativas com os Estados Unidos e do acordo com a empresa norte-americana Westinghouse Electric Group, e intensificou-se no governo Geisel, em especial devido ao aumento do preço dos combustíveis fósseis, decorrente do Choque do Petróleo de 1973.

Sob Geisel, o governo brasileiro manteve política agressiva de diversificação energética, com o objetivo de manter um "modelo brasileiro de capitalismo industrial" 44 e altas taxas de crescimento do PIB. Para isso, conforme ressaltado pelo II Plano Nacional de Desenvolvimento (II PND), o governo enfatizou o projeto de aumentar a geração de energia oriunda não apenas de fonte hidrelétrica, mas também de nuclear. Esta passou, inclusive, a ser considerada tecnologia estratégica para a sustentabilidade da economia brasileira e o governo passou a buscar, nominalmente, o desenvolvimento de tecnologia para produção de reatores "com adequado índice de nacionalização, e observados os aspectos da viabilidade econômica" (BRASIL, 1974, p. 115).

\footnotetext{
${ }^{43}$ Segundo Carlo Patti (2014a), entre os governos de Eurico G. Dutra e de Juscelino Kubistchek, o Brasil buscou, de forma não exitosa, obter tecnologia nuclear por meio de sucessivos acordos de cooperação nuclear, respectivamente, com os Estados Unidos, com a França e com a Alemanha Ocidental, além de ter solicitado conversações com a Noruega.

${ }^{44}$ BRASIL, 1974, p. 21.
} 
O autonomismo do II PND, consubstanciado, em 1975, pelo Acordo Nuclear BrasilAlemanha, marcou distanciamento com a política até então implementada, desde Médici, junto aos Estados Unidos e representou passo inicial para posterior intensificação do apelo autóctone da política nuclear brasileira da década de 1980. Verificou-se, dessa forma, a descontinuidade da política nuclear entre as administrações Médici e Geisel, motivada, principalmente, pela mudança no tom dos objetivos nacionais em energia nuclear, haja vista que, diferentemente de Médici, Geisel buscou obter, do exterior, transferência imediata de tecnologia sensível para enriquecimento de urânio. Apesar dessas descontinuidades, não se observou a transformações das políticas externas para a área nuclear, como ocorrerá posteriormente, com o governo Figueiredo e o estabelecimento do programa nuclear autônomo, cujas linhas mestres foram definidas no final do governo Geisel.

Ambos os governos, Médici e Geisel, desenvolveram políticas nucleares semelhantes, com relação aos objetivos externos. Esses objetivos pautaram-se, basicamente, pela busca de obter, do exterior, tecnologia nuclear para fins energéticos, considerada crucial para manter a estratégia do "milagre econômico". A busca em questão deu-se, principalmente, por meio de tratativas junto aos países do Norte Global, em especial Estados Unidos, Alemanha e, de modo menos exitoso, França, Reino Unido e Holanda.

A ênfase no Eixo Assimétrico da política nuclear é característica primordial do primeiro momento da política nuclear brasileira analisado nesta dissertação e o distingue dos dois momentos posteriores, quando se focará, respectivamente, no Eixo Sul e no Eixo Regional. Isso não significa que os demais eixos não tenham sido relevantes no período entre 1969 e 1978, porém, argumenta-se, implica menor importância relativa, se comparados com os demais. Dessa forma, optou-se por classificar, neste capítulo, o Eixo Assimétrico como o eixo principal da política nuclear nos governos Médici e Geisel, ao passo que os Eixos Sul e Regional foram denominados de eixos auxiliares, portanto menos relevantes, apesar de instrumentalizados na estratégia global da política nuclear.

O Eixo Assimétrico comporta as tratativas brasileiras no sentido de obter junto a países desenvolvidos insumos necessários para a implementação de tecnologia atômica em território pátrio. Embora a administração Médici tenha vislumbrado possível 
negócio com países como Suécia e Inglaterra ${ }^{45}$ e o governo Geisel com a França (PATTI, 2013), optou-se por concentrar a análise nas relações do Brasil com Estados Unidos e com Alemanha, que foram os principais atores a fornecerem tecnologia para o Brasil.

Como forma de melhor expor o panorama supracitado, o presente capítulo divide-se em cinco partes, sendo a primeira esta introdução. A segunda parte realiza um panorama do quadro energético brasileiro e das justificativas aventadas para o desenvolvimento de energia nuclear para fins energéticos, enquanto a terceira a parte analisa as tratativas realizadas no setor nuclear durante do governo Médici, em especial com os Estados Unidos. A quarta parte analisa a inflexão ocorrida no governo Geisel e as negociações com a França, com a Alemanha Federal, com a Inglaterra e com a Holanda. A quarta parte aborda os Eixos auxiliares da política nuclear desse período - o Eixo Regional e o Eixo Sul. A quinta parte consta das conclusões parciais.

\section{O panorama energético brasileiro na década de $\mathbf{1 9 7 0}$}

Dadas as características naturais do Brasil, o Governo Federal, sob Emílio Médici e sob Ernesto Geisel, optou por implementar programa de diversificação da matriz elétrica nacional que incluiria, principalmente, a utilização de energia advinda da queda d'água (hidrelétrica) e da fissão do átomo (nuclear) ${ }^{46}$. Esse programa foi mantido pelos governos Figueiredo ${ }^{47}$ e Sarney, porém via estratégias distintas, porquanto enquanto aqueles focaram no Eixo Assimétrico, estes optaram pela ênfase no Eixo Sul e no desenvolvimento autóctone.

A opção nuclear deveu-se ao fato de a energia advinda do átomo ser aquela "mais barata e menos poluente, depois da hidrelétrica"48, além de mais eficiente do que as de origem fóssil (HURRELL, 2013: 161) ou de origem renovável. Por essas características, bem como por sua possível utilização bélica, a energia nuclear passou a ser considerada, desde a década de 1960, pelos diferentes governos brasileiros, com elemento fundamental para a manutenção da divisão internacional de poder entre países do centro e da periferia.

\footnotetext{
${ }^{45} \mathrm{SF}, 1982$

${ }^{46}$ BRASIL, 1971

${ }^{47}$ BRASIL, 1974

${ }^{48}$ CN, 1990 , p. 47
} 
O programa de expansão da matriz energética brasileira na década de 1970 teve como objetivo manter a política econômica do milagre econômico, baseada no estímulo à demanda (consumo) e na industrialização da oferta brasileira, com criação de capacidade ociosa e mercados externos em países periféricos para os produtos nacionais. Essas duas facetas da política, deveriam ser bases para garantir o crescimento econômico do país a taxas próximas de $10 \%$ ao ano por um longo período temporal, o que deveria assegurar a entrada do país no grupo das maiores economias do mundo aquilo que, no período Médici, ficou conhecido por meio do slogan ufanista "Brasil Potência".

O horizonte de longo prazo do programa econômico ensejado pelos governos Médici governo alcançava a década de 1990 e o início do século XXI, e pode ser ilustrado pelas similaridades dos objetivos expostos no I, II e III PND, nos governos Médici, Geisel e Figueiredo, respectivamente. Apesar da certa continuidade, essas medidas de estímulo à demanda e à oferta, por meio de facilitação de crédito e de forte endividamento externo a juros flutuantes, foram minadas pelo súbito aumento do preço do petróleo e das taxas de juros internacionais, com o fim do padrão ouro-dólar, em 1971 e com os Choques de 1973 e de 1979.

Dados o potencial hídrico do Brasil, as reservas pouco exploradas de urânio, em especial no Nordeste, e a tentativa do governo de reduzir a vulnerabilidade externa ${ }^{49}$ do país, o governo brasileiro optou por basear o desenho do futuro parque energético nacional na combinação da construção de centrais hidrelétricas e nucleares. Estas foram tratadas como alternativa para prover o mercado nacional quando esgotasse o potencial energético das bacias hídricas da região Sudeste, onde se concentrava a maior parte da indústria brasileira.

Era de conhecimento dos policy-makers do Governo Federal que o a energia nuclear era mais cara do que aquela oriunda da queda d'água ${ }^{50}$, porém, segundo cálculos

\footnotetext{
${ }^{49} \mathrm{O}$ ponto da vulnerabilidade externa advinha da dependência das indústrias termoelétricas, nas quais se baseava a maior fatia do parque energético brasileiro, de carvão mineral oriundo do exterior e, em menor parcela, de petróleo, também importado.

${ }^{50}$ Essa diferença de preços pode ser ilustrada pela comparação feita entre os preços por KW em Angra I e a Usina de Itumbiara, expressa em artigo do Jornal do Brasil, em 1985: "A Usina Hidrelétrica de Itumbiara - a maior do sistema de Furnas - inaugurada no último dia 13 de Dezembro, com potência de 2 milhões 100 mil quilowatts (mais de três vezes superior à de Angra I, com seus 626 mil quilowatts), teve um custo substancialmente menor do que Angra I. Seu custo total, avaliado em 730 milhões de dólares (370 dólares por quilowatt instalado), foi o mais baixo dos últimos tempos para usinas deste porte. [...] A comparação adquire um caráter extremado, uma vez que o custo de Angra I por quilowatt instalado chega a ser aproximadamente oito vezes mais caro que o de Itumbiara, localizada no Rio Parnaíba, divisa de Goiás com Minas.” (JB, 19 jan.1985, p. 18)
} 
realizados por técnicos do MME, depois de 20 ou 25 anos o panorama deveria modificar-se, por causa do exaurimento das "possibilidades de ter eletricidade de origem hidrelétrica" ${ }^{2}$. Nesse caso, a alternativa clara seria a energia nuclear, devido à sua eficiência técnica, à disponibilidade de urânio natural no território brasileiro, ao peso simbólico dessa energia para questões de prestígio nacional. A energia nuclear, além disso, era fonte confiável, devido à sua larga utilização nos países do Norte Global, como Estados Unidos, com 74 usinas em funcionamento em 1978, Inglaterra, com 33, Japão, com 22, e Alemanha, com 15 e devido aos poucos acidentes até então ocorridos envolvendo essas usinas ${ }^{52}$. Tratava-se, além disso, de fonte energética em plena expansão pelo mundo ${ }^{53}$ e considerada altamente segura, visto que o primeiro acidente atômico envolvendo usina elétrica de repercussão global ocorreria, tão somente, em 1979, em Three Mile Island, Estados Unidos ${ }^{54}$.

Baseando-se no cenário do possível esgotamento do potencial energético dos mananciais da região Sudeste, foram, então, delineadas por técnicos da Nuclebrás, a mando do MME, ainda no governo Médici, duas estratégias alternativas para a implementação da energia nuclear no Brasil, expostas no Gráfico 1. Como pode ser observado, a primeira alternativa, a qual foi a escolhida pelo governo, era "implementar usinas nucleares e ampliar o uso da energia hidrelétrica de modo concomitante", enquanto a segunda estratégia, descartada, sugeria "esperar o potencial hidrelétrico para, então, implementar usinas nucleares de modo complementar" ${ }^{, 55}$. Esta foi rejeitada, pois, avaliou-se na época, geraria um grande problema, qual seja, a necessidade futura de implementar, ao mesmo tempo, ao redor de 8 usinas atômicas. Isso geraria custos consideravelmente mais elevados do que a alternativa adotada, cuja vantagem seria a possibilidade de, em um período maior, tanto diluir gastos no orçamento público imediato quanto construir maior número de usinas, conforme pode ser também observado no Gráfico 1.

\footnotetext{
${ }^{51}$ CN, 1990, p. 56. Depoimento de Othon Luiz. P. da Silva.

${ }^{52}$ Segundo dados levantados pela CNEN, em 1978. Para informações mais precisas sobre o número de usinas em serviço, em construção e encomendadas naquele ano, vide Anexo 1.

${ }^{53}$ O período entre 1970 e 1989 representou aquele de mais rápido aumento da produção mundial de energia advinda de matriz nuclear. Essa produção somente começou a cair no início dos anos 2000, ao redor de 2004, segundo da dados da BP. Para informações mais precisas sobre o assunto vide Anexo 2.

${ }^{54}$ Até 1984, dois dias antes do acidente de Chernobyl, a quantidade de reatores nucleares em funcionamento aumentou de forma considerável, atingindo naquele ano o pico de 30.000 megawatts de potência gerada ao redor do mundo e com a maior contribuição advinda dos Estados Unidos, segundo dados da AIEA, disponíveis na tabela Anexo 4.

${ }^{55}$ BRASIL, 1981, p. 13.
} 


\section{Gráfico 1 - Alternativas para a Implementação do Programa Nuclear Brasileiro}

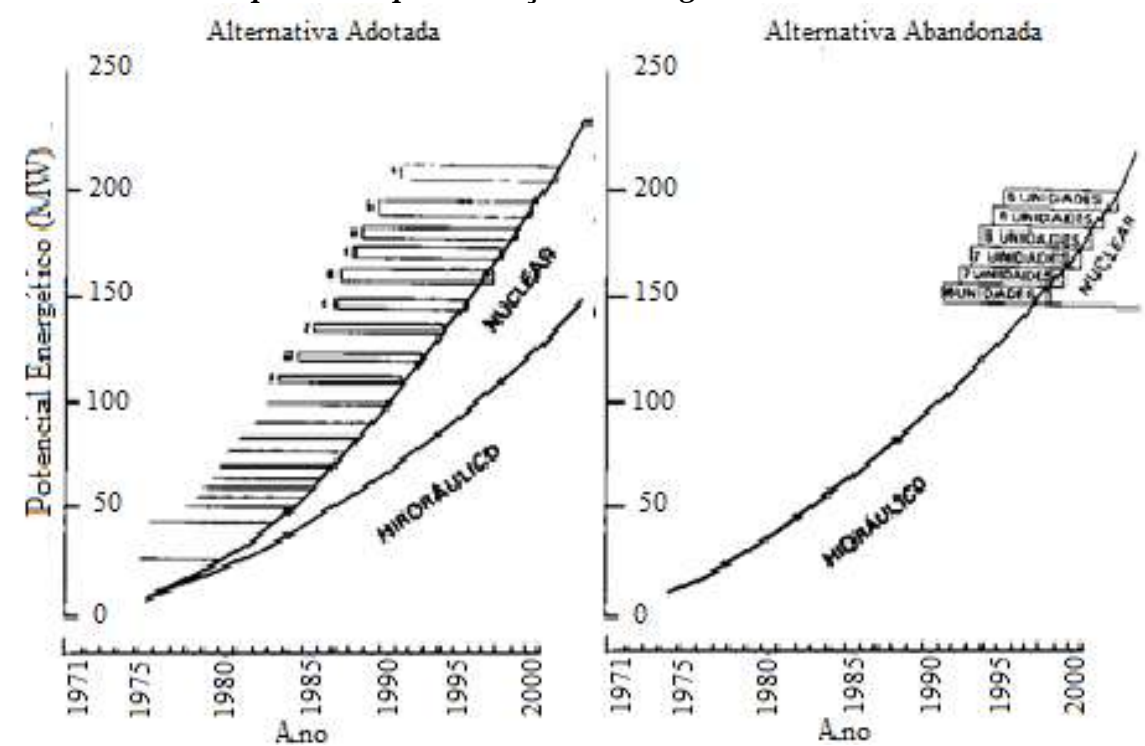

Fonte: BRASIL. Livreto Programa Nuclear Brasileiro: Governo Presta Contas, secretaria de comunicação social da presidência da república, 1981, p. 13.

Feita a opção do governo de consolidar, de modo consciente, a fonte nuclear na matriz energética brasileira, tornou-se necessário encontrar meios para obter a tecnologia de fissão atômica, bem como a tecnologia de enriquecimento de urânio. Para esta, três alternativas fizeram-se possíveis, enquanto que, para aquela, as alternativas foram duas. As três alternativas para o enriquecimento de urânio foram: ser importador de urânio enriquecido, aos preços e condições então prevalecentes; (2) tentar importar máquinas de enriquecimento para abastecimento próprio; (3) tentar, desde já, em associação com outro país detentor de tecnologia já industrializada, construir no Brasil usina para abastecimento do mercado mundial ${ }^{56}$. A primeira opção foi aquela instituída pelo acordo com a Westinghouse, por exigência daquela empresa, ao passo que a terceira opção foi aquela buscada por Geisel junto à França e à Alemanha.

No concerne à obtenção de tecnologia para fissão atômica, o que incluiria a conseguir reatores nucleares para a constituição de usinas comerciais, as duas alternativas elencadas, ambas já intentadas pelo governo brasileiro nas décadas de 1950 e de 1960, foram: (1) o desenvolvimento autônomo, como feito pela Argentina; (2) a cooperação internacional com países do Eixo Assimétrico , já detentores de tecnologia de enriquecimento de urânio e de fissão nuclear ${ }^{57}$. A alternativa escolhida por Médici e

\footnotetext{
${ }^{56}$ MRE, 19 Abril 1971

${ }^{57}$ MRE, 04 Abril 1974
} 
confirmada por Geisel foi a segunda, tanto pela rapidez do processo de implementação quanto pela possibilidade de obtenção de know-how de tecnologia de comprovadamente viável $^{58}$, diferentemente, por exemplo, da produção energética via urânio natural ${ }^{59} \mathrm{em}$ desenvolvimento por Buenos Aires ${ }^{60}$. A segunda alternativa, o desenvolvimento autóctone, seria, contudo, como exposto no capítulo 3 desta dissertação, retomada pelo governo Figueiredo, por causa de constrangimentos de ordem doméstica e internacional.

Em suma, optou-se, na década de 1970, por obter, de imediato, transferência de tecnologia nuclear para o Brasil, de modo a obter, do Eixo Assimétrico, os insumos energéticos necessários para manter a política econômica de longo prazo. Essa estratégia de cooperação internacional foi desenvolvida em duas fases, como se verá a seguir. A primeira fase foram as tratativas do governo Médici, as quais voltaram-se, principalmente, para os Estados Unidos, como se poderia esperar da inserção internacional do alinhamento (HIRST, 2009) ou do paradigma americanista (PECEQUILO, 2012). Diferentemente da primeira, a segunda fase ocorreu em um momento de mudanças internacionais e domésticas, marcadas pelo afastamento do Brasil da influência americana e pela busca de alternativas àquele país. Esse processo de afastamento relativo dos Estados Unidos e de simultânea busca de novas parcerias com o Norte Global, que culminou, na área nuclear, com o acordo Brasil-Alemanha de 1975, pode ser dominado de "vertente perturbadora" (LESSA, 1998) da política externa de Geisel, paradigma autonomista da política externa (HIRST, 2009), ou paradigma globalista (PINHEIRO, 2004; PECEQUILO, 2012).

\section{Cooperação tecnológica, rapidez e efetividade: as tratativas de Médici e a parceria com os Estados Unidos}

Afora os desenvolvimentos iniciais em cooperação nuclear desenvolvidos pelo governo brasileiro nas décadas de 1950 e de 1960, foi, tão somente, no governo Médici que o Brasil começou a propugnar consistente política contínua na área da energia

\footnotetext{
${ }^{58}$ BATISTA, 11 Nov. 1980.

59 Sobre a tecnologia de produção energética por meio de urânio natural, vale ressaltar a existência de grupos internos que entendiam ser essa a melhor alternativa para o caso brasileiro, como o caso do exministro da ciência e tecnologia do governo Collor, José Goldemberg, para quem "a compra de reatores americanos era um novo passo na linha do colonialismo", porque o tipo de urânio utilizado pelos reatores da Westinghouse é o Urânio ${ }^{255}$, o qual seria abundante nos Estados Unidos e na União Soviética, mas não no Brasil (GOLDEMBERG, 1976: 99-100). Dessa forma, a posição pessoal de Goldemberg seria o desenvolvimento de tecnologia por urânio natural, como o fazia a Argentina e como o fará, posteriormente, desenvolvido pelo Projeto Atlântico, abordado no capítulo seguinte.

${ }^{60}$ MRE, 04 Abril 1974, p. 6.
} 
atômica, a qual alcança até a atualidade. Essa política baseou-se, inicialmente, na busca de obter, de países do Norte Global - Eixo Assimétrico -, insumos necessários para consolidar no Brasil matriz de origem nuclear ${ }^{61}$. A opção inicial, considerada óbvia, era os Estados Unidos, país que com o qual o Brasil já desenvolvera, desde a década de 1940, incipiente relação de proximidade no campo nuclear, haja vista ações como o fornecimento de urânio para o Projeto Manhattan, na década de 1940, e a obtenção, em 1955, por meio do programa “Átomos para a Paz", de Dwight Eisenhower, o primeiro reator nuclear de pesquisa (PATTI, 2013: 51).

Embora o Brasil já mostrasse indícios de gradual afastamento e de crescentes divergências com os Estados Unidos (CERVO; BUENO, 2011, p. 408-409; VIZENTINI, 1998), o Governo Federal acordou com Washington a compra do primeiro reator nuclear comercial a ser instalado no Brasil, em 1971, pela empresa Westinghouse. Esse acordo representou vitória de grupos domésticos, presentes nas Forças Armadas e no Congresso Nacional, que almejavam desenvolver tecnologia nuclear de modo associado aos Estados Unidos e coadunou-se com os esforços das administrações Nixon e Ford de aproximar-se do Brasil.

Essa aproximação inseria-se no contexto mais amplo da gestão de Henry Kissinger na Secretaria de Estado, cuja principal marca foi a implementação consciente de política de compartilhamento de poder com potências regionais. Essa estratégia, denominada "ciclos minguantes" $" 62$, tinha base teórica no conceito de Equilíbrio de Poder do Concerto Europeu (1815-1914) ${ }^{63}$ (KISSINGER, 1995) e baseava-se no reconhecimento do desgaste da posição relativa dos Estados Unidos na ordem internacional, no "fim da pax americana" (PECEQUILO, 2005, p. 190) e no término da bipolaridade "no campo econômico" (SARAIVA, 2010b: 231-232). Esses constrangimentos empurrariam Washington na direção de repartir as responsabilidades para com a gestão da ordem internacional com as potências regionais emergentes, como a Alemanha Federal na Europa e o Brasil na América do Sul.

Apesar da intensificação de discurso contrário à proliferação nuclear e da tentativa frustrada de estimular a privatização completa do complexo nuclear nacional (WROBEL, 1986: 186), o governo Nixon, movido pela teoria dos "ciclos minguantes", incitou, em um primeiro momento, a aproximação com o Brasil de Médici na área

\footnotetext{
${ }^{61} \mathrm{SF}, 1982$

${ }^{62}$ MRE, 26 Mar. 1974

${ }^{63}$ MRE, 26 Mar. 1974
} 
atômica. Não obstante o caráter autoritário do regime brasileiro, o Departamento de Estado americano considerava essencial manter apoio, "de ordem econômica e militar" ${ }^{\text {, }}$, a Brasília, bem como aceitar, pragmaticamente, a ascensão e a manutenção dos militares no Executivo federal ${ }^{65}$, de modo a evitar "o reaparecimento de grupos comunistas no maior Estado sul-americano"66.

Em especial para Richard Nixon e para Henry Kissinger, o qual não confiava no governo argentino de Alejandro Lanusse ${ }^{67}$ e o qual apostava na intensificação da rivalidade brasileiro-argentina, visto que Médici também desconfiaria do general portenho $^{68}$. Mesmo durante o início do governo Geisel, quando as relações com os Estados Unidos passaram por momento de intensificado distanciamento (HIRST, 2009; PECEQUILO, 2012), Kissinger, então Secretário de Estado do governo de Gerald Ford, tentou manter, embora de maneira menos exitosa, as boas relações com o Brasil ${ }^{69}$, conforme ilustrado pelo voto favorável do Secretário de Estado em meio à comissão da Agência Internacional de Energia Atômica (AIEA) que tratará do posterior Acordo Brasil-Alemanha, de 1975 (MONIZ BANDEIRA, 1989, p. 230).

Em meio a esse contexto, o governo brasileiro, em 1971, por meio da lei 5740, autoriza a Comissão Nacional de Energia Nuclear (CNEN) a criar a Empresas Nucleares Brasileiras S/A (Nuclebrás), a qual seria incorporada ao sistema Furnas e cuja principal função seria gerir as usinas atômicas a serem constituídas em território nacional. A Nuclebrás, com o apoio do Governo Federal, iniciou processo de busca de contratação de empresas estrangeiras capazes de vender ao Brasil reatores nucleares, para o que ela obteve amplo apoio do Governo Federal $^{70}$.

\footnotetext{
${ }^{64}$ DEPARTMENT OF STATE, 18 Mar. 1969. Tradução Própria.

${ }^{65}$ DEPARTMENT OF STATE, 1 Nov. 1969. Tradução Própria.

${ }^{66}$ DEPARMENT OF STATE, undated. Tradução Própria.

67 "President Nixon said that he was concerned about the [economic and political] situation in Argentina and would be very happy if President Medici would tell him his impressions after the Lanusse visit." DEPARTMENT OF STATE, 07 Dec. 1971

68 "The most serious problem in South America is the Brazilian-Argentine relationship itself. [...] $[R]$ elations between military and police leaders in two countries are quite good, ref by documents fact that Lanusse personally is disliked and distrusted by Brazilian leadership, and his visit viewed as an unavoidable if distasteful necessity by both presidency and Itamaraty. Hence aside form fact that MediciLanusse conversation (which officially planned last only fifty minutes) would be difficult to manipulate from outside, we seriously doubt that this would be the forum to kick off genuine cooperation." DEPARTMENT OF STATE, 07 Mar. 1972.

${ }^{69}$ Os objetivos de Kissinger incluíam a manutenção Brasil na órbita dos Estados Unidos, na medida em que "If Brazil were to be lost it would not be another Cuba. It would be another China" (DEPARTMENT OF STATE, sem data, p. 2)

${ }^{70} \mathrm{SF}, 1982$
} 
Relevante notar que, diferentemente do que ocorrerá no governo Geisel, o processo de licitação organizado pela Nuclebrás e pela Furnas $^{71}$ para a compra de reatores nucleares estrangeiros não teve como critério a transferência de tecnologia. Segundo relatório da CPI do Senado Federal de 1982 sobre a questão nuclear(SF, 1982, p. 169), os critérios utilizados pela estatal brasileira foram, tão somente, a "garantia de qualidade e de performance", além do menor preço total ajustado.

De acordo com esses critérios, conforme observado no Quadro 2, a proposta da Westinghouse demonstrou-se, consideravelmente, mais competitiva do que as demais, devido à maior potência estimada para a usina, o menor custo da energia em $\mathrm{Cr} \$ / \mathrm{KWh} \mathrm{e}$ o menor preço ajustado. Além disso, a proposta contava com o aval de Washington para o financiamento do projeto pelo Eximbank e previa consultas advindas das empresas de engenharia americanas Gibbs \& Mill e Bechtel, de modo a garantir a eficiência e o menor custo da usina a ser construída. Essas características tornaram, naquele momento, a proposta da Westinghouse substancialmente mais competitiva do que as demais, apesar de condicionar o acordo à importação de urânio enriquecido nos Estados Unidos e de proibir, nominalmente, o Brasil de violar as patentes americanas relativas aos equipamentos importados ${ }^{72}$.

Quadro 2 - Comparação das Propostas, em mil* de cruzeiros

\begin{tabular}{|c|c|c|c|c|c|}
\hline \multirow[b]{2}{*}{ Empresas } & \multirow[b]{2}{*}{ Nacionalidade } & \multirow{2}{*}{$\begin{array}{l}\text { Potência } \\
\text { Estimada }\end{array}$} & $\mathrm{Cr} \$ / \mathrm{KWh}$ & Tr\$ (em milhões) & Cr\$ (em milhões) \\
\hline & & & $\begin{array}{l}\text { Custo de } \\
\text { Energia }\end{array}$ & $\begin{array}{c}\text { Preços na Potência } \\
\text { original }\end{array}$ & Preços Ajustados \\
\hline Westinghouse & EUA & $660 \mathrm{MW}$ & 0,0523 & $1.188,8$ & $1.050,2$ \\
\hline TNPG & Reino Unido & $466 \mathrm{MW}$ & 0,0592 & $1.155,8$ & $1.187,7$ \\
\hline General Electric & EUA & $524 \mathrm{MW}$ & 0,06005 & $1.352,2$ & $1.213,6$ \\
\hline Siemens & Alemanha & $524 \mathrm{MW}$ & 0,0611 & $1.259,5$ & $1.226,2$ \\
\hline AEG & Alemanha & $529 \mathrm{MW}$ & 0,0624 & $1.291,4$ & $1.251,2$ \\
\hline
\end{tabular}

*obs.: 1 mil equivale a um milésimo de dólar.

Fonte: Senado Federal, 1982, p. 169. Elaboração própria.

Dessa forma, pode-se admitir que a escolha da Westinghouse se coadunou, de acordo com os critérios estabelecidos pela licitação, com os objetivos imediatos da

\footnotetext{
${ }^{71}$ Como fazia parte do sistema Furnas, a Nuclebrás dependia financeiramente daquela tanto para construir quanto para operar as usinas nucleares sob sua tutela. Furnas também era a responsável pelo processo de engenharia civil que envolvia as usinas nucleares futuras.

${ }^{72}$ SF, 1982, p. 171
} 
administração Médici, os quais instavam a construção rápida e efetiva de usina nuclear no território brasileiro, para atender à política de rápido crescimento econômico. Conforme enunciado no I PND ${ }^{73}$, o objetivo precípuo do governo Médici apenas era implementar, em, um primeiro momento, uma usina nuclear no Brasil. Após a implementação, em uma segunda fase, caberia à Companhia Brasileira de Tecnologia Nuclear $(\mathrm{CBTN})^{74}$ iniciar processo de gradual assimilação dessa tecnologia pelo parque tecnológico brasileiro.

Apesar de o Brasil ter conseguido obter sua primeira usina nuclear para fins comerciais, Angra I, nos objetivos de longo prazo, qual sejam, a assimilação de tecnologia pela CBTN, o governo não foi exitoso, devido a mudanças nos quadros interno e externo a seguir exploradas. Coube ao governo Geisel modificar o formato da cooperação externa ensejada pelo Brasil, porém mantendo a ênfase do Governo no Eixo Assimétrico das relações bilaterais da Política Nuclear brasileira.

\section{Tempos de adaptação: a política nuclear de Geisel}

\subsection{Novos condicionantes domésticos e externos}

Na segunda metade da década de 1970, a política externa brasileira de cooperação nuclear passou por ponto de inflexão, devido a três mudanças de ordem doméstica e internacional: (1) a mudança na política nuclear norte-americana; (2) o choque do petróleo de 1973; (3) a ascensão de Geisel à Presidência da República e a concomitante mudança de grupos políticos internos, com a volta dos "sorbonistas".

O primeiro fator mencionado ocorreu ainda nas administrações Nixon-Ford, embora tenha sido notado com maior intensidade no governo Carter. Essas mudanças internas na administração americana e nas regras comerciais relativas à comercialização de urânio podem ser consideradas uma das principais razões para o afastamento entre Brasília e Washington no campo nuclear, conforme explicitado pelo embaixador Sebastião Rego Barros ${ }^{75}$. A mudança na política nuclear americana deveu-se ao fracasso da tentativa do presidente Richard Nixon de privatização do complexo nuclear norte-

\footnotetext{
${ }^{73}$ BRASIL, 1971, p; 59-60

${ }^{74}$ A CBTN foi empresa criada em 1971, pela Lei № 4.118, e absorvida pela Nuclebrás três anos depois, pela lei $\mathrm{N}^{\circ}$ 6.189, de 16 de Dezembro de 1974. Essa empresa tinha como objetivo precípuo conduzir, após a construção de Angra I, o processo de absorção da tecnologia de enriquecimento de urânio e de fissão nuclear, porém teve pouca relevância na política nuclear brasileira. Isso pode ser corroborado por sua rápida absorção pela Nuclebrás.

${ }^{75}$ Interferência do embaixador Sebastião Rego Barros no seminário História Oral Crítica (In.: MALLEA et at, 2015, p. 76)
} 
americano( WROBEL, 1986), elaborada para dar maior competitividade às empresas americanas de tecnologia nuclear, bem como para reduzir os gastos do Executivo nacional, que ainda controlava parte do processo de extração e enriquecimento de urânio $^{76}$. Esse fracasso ficou evidente com a perda de competitividade das empresas americanas em relação às europeias e japonesas, cujos governos ainda as apoiavam (WROBEL, 1986). Igualmente importante para a mudança da política americana foi a primeira explosão atômica indiana, em 1974, a qual demonstrou o fracasso da política de não proliferação horizontal assentada no TNP.

Para tentar suprir o fracasso da privatização e desburocratização do setor nuclear, o governo Nixon implementou duas medidas relevantes. Para manter o oligopólio no mercado nuclear e, ao menos no discurso, assegurar a não proliferação, o governo americano liderou a criação do Grupo dos Supridores Nucleares (WROBEL, 1986; PATTI, 2013a, p. 182), enquanto que, no ambiente doméstico, o Congresso Americano alterou as regras para exportação de urânio enriquecido, de modo a dificultar o acesso desse material a países considerados pouco afeitos ao regime internacional de salvaguardas nucleares vigente (SKIDMORE, 1990, p. 193), como o Brasil. Esta mudança de regras levou, porém, à conformação de marco normativo confuso e desorganizado, o qual não deixava claro, por exemplo, os limites das empresas nas negociações internacionais, na medida em que, ao mesmo tempo em que a essas empresas era concedido controle do processo de enriquecimento de urânio, a legislação as proibia de exportar urânio enriquecido a determinados países.

Não obstante o acordo trilateral de salvaguardas assinado, em 27 de julho de 1972, em Viena, entre o Brasil, os Estados Unidos e a AIEA, a decisão do Congresso Americano afetou, de imediato, o projeto de consolidação do parque nuclear brasileiro, porquanto implicou impedimento da importação de urânio pelo Brasil. Essa proibição relaciona-se à postura brasileira contrária ao TNP, por considerá-lo discriminatório, bem como às reservas feitas ao Tratado de Tlatelolco, as quais, prática, o haviam tornado nulo $^{77}$ para o Brasil (REDRICK, 1975, p. 423). Posteriormente, ainda na década de

\footnotetext{
${ }^{76}$ Essa política de privatização baseou-se em duas áreas principais. A primeira foi a emissão de licenças para empresas como a General Electric, a Westinghouse e a Betchel permitindo o controle e a comercialização de todas as fases do processo de enriquecimento de urânio em território americano, ao passo que a segunda fase foi a desburocratização do mercado energético americano, o que deveria contribuir para poupar recursos, os quais poderiam ser utilizados na melhora da eficiência energética de áreas como a transmissão.

77 Entre as reservas que contribuiriam para essa nulificação pode-se destacar a ressalva relativa à possibilidade de desenvolvimento de artefatos nucleares para explosões pacíficas e a necessidade de adesão a Tlatelolco de todos os países nucleareziados do mundo, para que o tratado entrasse em vigência
} 
1970, concomitantemente com o final do governo Geisel, o governo de Jimmy Carter restringirá ainda mais o acesso a urânio enriquecido a países como o Brasil. Essa intensificação as barreiras à importação e urânio pelo Brasil ocorreram apesar de o presidente americano ter enfatizado, em discursos, os avanços na cooperação nuclear com o Brasil $^{78}$, em contraste com as dificuldades apresentadas pela Argentina ${ }^{79}$, cuja postura ainda mais incisiva que a brasileira dificultaria a efetividade do regime regional de não proliferação nuclear na América Latina.

O segundo fator, o Choque do Petróleo de 1973, foi especialmente relevante no caso brasileiro, pois colocou em risco a estratégia de crescimento então desenvolvida pelos governos Médici-Geisel, a qual se baseava na importação intensiva de petróleo e no alto endividamento externo. $\mathrm{O}$ aumento elevado dos preços do petróleo, decorrente de política da Organização dos Estados Produtores de Petróleo (OPEP) após a Guerra do Yom Kippur, tornou evidente a necessidade de o Brasil diversificar sua matriz energética, para o que a opção nuclear tornou-se elemento crucial, conforme exposto anteriormente.

Do Choque do Petróleo decorreram duas reações do governo de Ernesto Geisel no campo atômico. Em primeiro lugar, governo brasileiro passou a buscar internacionalmente condições para adquirir tecnologia de enriquecimento de urânio que possibilitassem antecipar a independência nacional na área atômica, ensejada por Médici para o médio e longo prazo (PATTI, 2013: 173-174 ; KOLLMANN, 2012 ; VIZENTINI, 1998). Em segundo lugar, destaca-se a tratativa de Geisel de usar os "petrodólares" disponíveis no mercado global de capitais para financiar o programa nuclear brasileiro ${ }^{80}$, dessa forma mantendo as linhas gerais do modelo econômico baseado no alto endividamento externo previsto no II PND.

A terceira e última mudança ocorrida na década de 1970 foi a ascensão de Ernesto Geisel à Presidência da República e a implementação de política externa

para o Brasil. Esse último foi particularmente dificultado pela postura soviética e chinesa (GROSS ESPIELL, 1973).

78 "In Brazil, one of our close allies over the years, we reestablished the understanding of the long-term, common interests and friendship between our people. And we stressed, perhaps in different ways, our mutual concern about nuclear nonproliferation and human rights." (CARTER, 3 Abr. 1978)

79 "We have tried as best we could to put an absolute lid on proliferation of nuclear explosives in this hemisphere, other than those that we ourselves retain for the defense of the hemisphere. The Treaty of Tlatelolco is one on which we've invested a great deal of effort. And we are now approaching the point where all of the Latin American countries involved, and the European and Eastern European countries who have a direct relationship, will also have espoused this commitment not to have nuclear weapons be located within this tremendous and important region of our world. It'll be the first region if we secure the remaining endorsements of the treaty—shortly from, perhaps, Argentina. "(CARTER, 22 Sept. 1978)

${ }^{80}$ MRE, 18 Nov. 1974 
abertamente afeita à busca de expansão das parceiras internacionais do Brasil. Embora tenha mantido algumas linhas da atuação de Médici, Ernesto Geisel e Antônio F. Azeredo da Silveira implementaram política que modernizou a retórica defensiva do país em meio aos principais regimes internacionais e que revisou o "tratamento dos vínculos com os principais relacionamentos do país" (SPEKTOR, 2004: 196).

Essa revisão foi particularmente relevante naquilo que concerne às relações com os Estados Unidos, com os quais Geisel implementou política de gradual afastamento, dessa maneira substituindo o "paradigma americanista" pelo "globalista" (PECEQUILO, 2012; PINHEIRO, 2000). De fato, conformou-se, com relação aos Estados Unidos, aquilo que Antônio C. Lessa (1998) chamou de "vertente perturbadora" da política externa de Geisel e que Mônica Hirst (2009) chamou de fase da "autonomia" nas relações brasileiro-americanas, processos esses que contribuíram largamente para aproximar o Brasil dos países da Europa Ocidental no campo nuclear, conforme corroborado pelas posteriores.

Dessa forma, em meio a contexto internacional restritivo, caracterizado pelo choque do petróleo de 1973 e pela mudança da política nuclear americana, o Brasil de Geisel optou por buscar alternativas à parceria com os Estados Unidos, as quais possibilitassem, na área nuclear, transferência real de tecnologia de enriquecimento de urânio que pudesse ser rapidamente assimilada pela indústria nacional. Essa inflexão pode ser observada no II PND, o qual, diferentemente do primeiro, coloca maior ênfase na busca da autonomia nacional no que se refere ao controle do ciclo do átomo. $\mathrm{O}$ governo Geisel, por meio da cooperação entre Itamaraty, CNEN, MME, Nuclebrás e outras agências governamentais, irá buscar na Europa alternativas à opção americana ${ }^{81}$. As alternativas europeias, analisadas a seguir, ocorreram, basicamente, em três opções, sendo a segunda a única exitosa. A primeira opção, considerada preferencial devido à viabilidade da tecnologia, foi a França, enquanto a segunda e a terceira opção foram, respectivamente, a Alemanha Federal e a URENCO - uma empresa anglo-teutoholandesa, também supridora de tecnologia comprovadamente viável.

\footnotetext{
${ }^{81}$ Conforme lembra Patti (2013a, p. 173), a opção pela Europa fez-se como a principal alternativa vislumbrada pelo governo brasileiro, visto que, apesar de a União Soviética ter entrado no mercado nuclear ocidental ainda na década de 1970, o governo militar brasileiro não a via como alternativa viável, devido a suposto anticomunismo. Essa postura em relação a países socialistas mudará na década de 1980, com tratativas secretas do presidente Figueiredo de obter apoio chinês para o programa nuclear autônomo (NEDAL, 2013).
} 


\subsection{A tratativa francesa}

Apesar de ser pais com o qual o Brasil mantinha relações aquém de seu potencial econômico-comercial (LESSA, 2013), a França foi a primeira e a principal opção de cooperação na área nuclear vislumbrada pelo governo nas fases iniciais. Essa opção deveu-se tanto pela presença francesa nas décadas anteriores, inclusive com viagens e reuniões entre o almirante Álvaro Alberto e membros do Commissariat à l'Energia Atomique (CEA) em 1953 (PATTI, 2015), quanto pela comprovada eficácia do método francês de enriquecimento de urânio por difusão gasosa. Conforme afirma Paulo Nogueira Batista ${ }^{82}$, esse método, cujo uso em escala comercial já era feito na França, tornava o hexágono parceiro preferencial para a importação de máquinas de enriquecimento de urânio para abastecimento próprio, caso o Brasil optasse por esse caminho.

A década de 1970 viu-se marcada pela abertura do mercado mundial de energia nuclear e pelo estabelecimento de economia de plutônio, ambiente no qual a França, por meio de estratégia de inserção fortemente pautada pelo peso do Estado nacional (JASPER, 1992), buscava ampliar a utilização de sua tecnologia autonomamente desenvolvida no início da década de 1960. Considerando que o tamanho do mercado brasileiro, esperava-se que a cooperação francesa adviria dos benefícios comercias que aquele país obteria, bem como ao prestígio que adviria dessa cooperação. Embora aquele pareça mais relevante que este, vale destacar que o prestígio seria elemento posterior a motivar, na visão do Auswärtige Amt, a posterior cessão por Paris de documentos contendo instruções para o desenvolvimento de tecnologia atômica ao Paquistão ${ }^{83}$, bem como traço fundamental da política externa francesa desde o governo de Charles de Gaulle, sob o moto tous azimuts ${ }^{84}$. Além disso, deve-se destacar um último "trunfo" (MRE, 19 Abril 1971, p. 2) brasileiro, qual seja, oferecer à França a possibilidade de comprar energia brasileira advinda do médio São Francisco a preço muito inferior ao europeu e ao norte-americano. Isso seria útil, por exemplo, para abastecer a Guiana Francesa.

\footnotetext{
${ }^{82}$ MRE, 19 Abril 1971

${ }^{83}$ AA. 16 Feb. 1977

84 A política do tous azimuts, ou "todos os caminhos", desenvolvida pelo governo de Charles de Gaule (1959-1969) instava a França a buscar grandeza por meio de análise de todos os caminhos possíveis, que levassem o Hexágono a inserção internacional relevante e intendente de constrangimentos advindos de países como os Estados Unidos. Essa proposta de tom diplomático foi mantida pelo governo de Valéry d"Estaign (1974-1981) (BACH, 1985, p. 155) e influiu na estratégia francesa de cooperação nuclear com países do Sul Global e de venda de armas (ANDREWS, 1980).
} 
Com a França, o governo brasileiro ensejou duas formas alternativas de cooperação, ambas as quais poderiam possibilitar a aquisição e centrífugas de enriquecimento de urânio por difusão gasosa. A primeira alternativa era a obtenção direta de reatores e tecnologia nucleares oriundos da França, pela via direta do governo central em Paris; ao passo que a segunda alternativa seria projeto de cooperação trilateral envolvendo Paris e Bonn, o qual envolveria tanto a imediata transferência de urânio enriquecido quanto a transferência de know-how completo em prazo de dez anos ${ }^{85}$. A segunda alternativa era de interesse especial de Bonn, pois contribuiria para que a Alemanha Federal abrisse outra frente de colaboração nuclear, além do projeto trilateral anglo-teuto-holandês da $\mathrm{URENCO}^{86}$.

A alternativa francesa não foi exitosa, apesar da transferência para o Brasil de um reator experimental para enriquecimento de urânio, em 1975, denominado Cobra $^{87}$ e implementado no Rio de Janeiro. O insucesso da cooperação com a França deveu-se, primordialmente, à demora dos franceses em dar resposta clara e positiva a Brasília ${ }^{88}$, devido a restrições que ainda pesavam sobre

“a FRAMATOME ${ }^{89}$ quanto à livre disposição da licença Westinghouse para construção de reatores PWR e também se achava envolvida a França em esforços para atrair terceiros países a participarem da construção em território francês da usina de enriquecimento, o chamado projeto COREDIF"90.

Além disso, outro problema crucial a bloquear as tratativas franco-brasileiras foi $o$ requerimento da EURATOM de adiamento em um ano de qualquer fornecimento de urânio ao Brasil, devido a requerimento feito por Washington a partir do acordo bilateral Euratom-Estados Unidos. Para os Estados Unidos, o Brasil, para obter urânio enriquecido ou tecnologia nuclear francesa deveria assinar com os Estados Unidos

\footnotetext{
${ }^{85}$ BATISTA, 11 jun. 1975; MRE, 19 Abril 1971

${ }^{86}$ AA. 17 Jun. 1977.

${ }^{87}$ Conforme texto oficial da boletim do CEA: "Un réacteur expérimental français pour le Brésil. M. Nogueira Batista, Président de la Société Empresas Nucleares Brasileiras S.A. (Nuclebras) [...] et M. Rémy Carle, Président de la Société Technique pour l'Énergie Atomique (Technicatome) ont signé à Paris, le 4 juillet 1975, un contrat pour la réalisation au Brésil d'un réacteur expérimental denommé Cobra. Ce réacteur, dérivé du réacteur français Minerve en fonctionnement au Centre d'Études Nucléaires de Fontenay-aux-Roses est dans la ligne des réacteurs de la filière à nêutrons rapides qui ont conduit en France à Rapsodie puis à Fênix. Le projet Cobra permettra notamment l'étude des coeurs des réacterus suregénérateurs qui constitueront dans un proche avenir la nouvelle génération des centrales nucléaires”. (MRE, 26 Março 1974)

${ }^{88}$ BATISTA, 11 nov. 1980.

89 A Societé Franco-Américaine de Constructions Atomiques S/A (FRATOME) é uma empresa de geração de energia nuclear francesa, com sede em Paris.

${ }^{90}$ BATISTA, 11 nov. 1980, p. 4
} 
acordo similar àquele assinado pela Euratom, o que, na prática, contribuiu para impossibilitar as tratativas com Paris ${ }^{91}$.

\subsection{A opção alemã}

Com o insucesso da tratativa francesa, a qual era a opção prioritária do Brasil de cooperação nuclear, o governo Geisel aceitou a proposta alemã de parceria abrangente e com transferência de tecnologia ainda experimental de enriquecimento de urânio. A atratividade da parceira teuto-brasileira estava, além da transferência de tecnologia, na previsão de formar quadros nacionais especializados na gestão da tecnologia nuclear. Este ponto constituía pilar fundamental da estratégia da Nuclebrás de consolidação do complexo nuclear brasileiro ${ }^{92}$. Além disso, vale salientar que essa opção alemã já fora anteriormente oferecida por Bonn a Brasília nas décadas de 1950 e de 1960, porém rejeitada pelos governos então incumbentes, ao passo em que as propostas americanas iam-se implementando (PATTI, 2014b).

É relevante salientar que, quando o Brasil anunciou que pretendia construir oito novas usinas nucleares com provável tecnologia alemã, o governo recebeu contrapropostas relevantes de empresas americanas, receosas de perder o promissor mercado brasileiro. A própria Westinghouse, após fracasso da tentativa de realizar lobby junto ao Congresso Americano para obter permissão de exportar maior quantidade de urânio enriquecido ao Brasil (PATTI, 2013: 182), oferece a Brasília contrato para a compra de uma quantidade maior de reatores (SKIDMORE, 1990: 194) a preços ainda mais competitivos do que aqueles de Angra I. A proposta da empresa americana não é aceita porque, apesar de oferecer tecnologia mais eficaz do que a alemã e de envolver aquisição de um número maior de itens, ela não previa a transferência imediata de tecnologia, elemento que, diferentemente do que ocorreu no governo Médici, era condição crucial para Geisel ${ }^{93}$.

\footnotetext{
91 "the Brazilian Embassy in Paris inquired of the French government on the motives that had caused the one-year postponement, and learned from the authorities in France that the Euratom Supply Agency had consulted with the United States government on the matter prior to any retransfer could take place, in the terms of a bilateral Euratom-United States agreement on the control of highly enriched uranium fuels. The response of the United States Government was that the retransfer could not be authorized because Brazil had not complied with all the necessary requirements, i.e., that the Brazilian government had not previously entered into an agreement with the United States government on the control of highly enriched uranium fuels, similar to the one which had been signed with Euratom" (MRE, 26 Março 1974).

${ }^{92} \mathrm{SF}, 1982$, p. 247

${ }^{93}$ SF, 1982, p. 188
} 
Também a empresa norte-americana Betchel Corporation, a qual prestou consultoria para a construção de Angra I, apareceu, de modo inusitado, no processo de apresentação de propostas ao Brasil. Conforme lembra Paulo Wrobel (1986, p. 188), a empresa teria oferecido ao Brasil tecnologia sensível cuja venda era proibida pela nova legislação americana, implementada pelo congresso americano no governo Nixon. A história teria sido divulgada pela mídia americana, do que decorreu grande repercussão nacional. Como resposta, a empresa afirmara que a notícia seria fruto de um "executivo mais afoito" (WROBEL, 1986: 132), que havia interpretado erroneamente a confusa legislação reguladora da privatização do processo de enriquecimento de urânio.

Diferentemente dos Estados Unidos de Nixon-Ford, que passavam por processo de restrição da política de não proliferação, e da França, que apresentava estratégia atômica já claramente definida desde fins da década de 1950, a Alemanha Ocidental empreendia transformação de sua estratégia de inserção no mercado mundial nuclear. Isso possibilitou a este país desenvolver política nuclear mais ambiciosa, na medida em tanto a mídia quanto a diplomacia alemãs (WROBEL, 1986: 126; KRAUSE: 1) apoiavam a ambição do governo de expandir comercialmente sua presença no mercado atômico global e apoiavam o desenvolvimento de tecnologia nuclear para fins pacíficos (VON BREDOW, 2006:146).

A Alemanha Federal passava, sob a administração de Helmut Schmidt (1974-1982) e do Partido Social-Democrata da Alemanha (SPD), por reformulação da sua política externa na área da cooperação nuclear. Retornava à pauta a questão do sonderweg (caminho próprio) alemão, uma discussão tradicional da análise da política externa alemã, agora aplicada ao setor nuclear. Conquanto a política externa de Bonn se tenha firmado, desde 1949, sob as bases do pacificismo, da aliança com as potências ocidentais e da democracia, definidas por Konrad Adenauer no início da República Federal (VON BREDOW, 2006: 135), a chancelaria de Schmidt optou por revisar a aplicação das linhas mestras da diplomacia germânica na questão da cooperação nuclear, de modo a torná-la mais flexível e menos conivente com os interesses da superpotência americana.

Como lembram Gunther Hellmann et al. (2006, p. 190), a opção alemã de não possuir arsenal atômica é tema considerado pacífico na política germânica e aceito pelo opinião pública, apesar de o governo de Bonn ter admitido a possibilidade de dominar a tecnologia utilizada para a construção de armamentos nucleares (i.e. tornar-se potência nuclear latente). Essa postura, inicialmente imposta pelas potências vencedoras da 
Segunda Guerra Mundial, foi considerada, desde Adenauer, uma barreira intransponível pela República Federal, cuja própria problematização seria inócua. Isso se justificava pela opção alemã de não se militarizar excessivamente, após a experiência nazista, e pelas limitações impostas pelo Acordo de Paris de 1954, as quais limitavam a capacidade de os alemães "produzir(em) urânio enriquecido no seu próprio território" (MRE, 19 Abril 1971), portanto instando Bonn a buscar obter tecnologia nuclear por meio de acordo tripartite com a Holanda e com a Inglaterra, formando a URENCO.

Apesar dessas limitações, a chancelaria de Schmidt colocou o tema da modificação da política nuclear, abertamente, na pauta política (VON BREDOW, 2006, p. 147). Unindo na mesma agenda a participação alemã na Organização do Tratado do Atlântico Norte (OTAN), a presença germânica no "guarda-chuva" nuclear americano ou francês e a possível opção por buscar arsenal nuclear próprio, Schmidt propôs discussões amplas e abertas, as quais levaram à definição de estratégia nuclear clara, a qual pautasse o sonderweg alemão para questões atômicas. Dessas discussões, realizadas no parlamento alemão e na chancelaria, chegou-se a uma política nuclear de tom brando, que propugnava cooperação com países periféricos, como Brasil e África do Sul, para o desenvolvimento conjunto de tecnologia nuclear para fins exclusivamente energéticos.

Essa estratégia envolvendo o Sul Global também tinha como objetivo inserir a Alemanha, de maneira competitiva, no lucrativo mercado mundial de tecnologia nuclear, e coadunava-se a finalidade de aquele país adquirir primazia no sistema internacional por meio da ampliação de suas redes de comércio e de seu poder de influência na economia internacional ${ }^{94}$. A procura alemã de parceiros periféricos para expansão comercial também se coadunava com o discurso brasileiro ${ }^{95}$, na medida em que, enquanto o Brasil acusava, abertamente, as potências atômicas o GSN de tentarem manter divisão internacional do trabalho injusta (MONIZ BANDEIRA, 1989, p. 237; SF, p. 258), Bonn afirmava que a melhor maneira de evitar a proliferação de armas nucleares era, não por restrições, mas por meio da "solidariedade dos fornecedores"96 com os países receptores de tecnologia.

\footnotetext{
${ }^{94}$ A essa política de obter maior poder de ingerência nas relações internacionais pela via econômica, ao que se acrescenta a aceitação de certa obsolescência do poder material militar nas relações inter-estatais, Richard Rosecrance (1986) denominou “ ascensão do Estado Comercial”. Vale salientar que, para Rosecrance, os exemplos mais evidentes desse processo eram a Alemanha e o Japão.

${ }^{95}$ As principais premissas e diretrizes do discurso brasileiro na área nuclear foram tratadas no capítulo1 desta dissertação.

96 “ $Z u$ den pakistanischen Behühungen, mit uns über die $N V$-politischen Lieferbedingungen eines $K K W z u$ sprechen, könnten wie gegenüber den USA gemäß Schreiben des Herrn Bundesministers na AM Shultz.
} 
O chamado sonderweg nuclear alemão acabou por levar a República Federal a buscar, de forma contínua e agressiva, obter mercados consumidores capazes de sustentar sua indústria nuclear ${ }^{97}$ (KRAUSE, 2005, p. 1-2). Nesse contexto, o Brasil adquiriu grande relevância para Bonn, porquanto seu grande mercado consumidor e o potencial de consumo energético de sua indústria tornaram o país fundamental para a estratégia de expansão da indústria energética alemã. De fato, o tratado firmado entre a Alemanha e o Brasil, em 1975, possuiu lugar único na política alemã, devido à sua abrangência e ao ímpeto alemão em tornar o acordo com o Brasil exemplo da possibilidade de verdadeira cooperação entre países do Norte e países do Sul global em matéria sensível ${ }^{98}$. Isso não significa, porém, que Bonn desejasse replicar a cooperação com o Brasil, em seus exatos termos, com outros países periféricos ${ }^{99}$, mas implica, tão somente, reconhecimento da singularidade do Brasil ante outros possíveis parceiros vislumbrados pela Alemanha Federal, como o Irã, com o qual Bonn, ainda em 1976 ${ }^{100}$, buscou desenvolver cooperação, apesar de reações negativas similares recebidas dos Estados Unidos.

O potencial energético do Brasil e o apoio do governo federal alemão para cooperação internacional eram fatores especialmente relevantes para a empresa Kraftwerkunion (KWU), subsidiária do grupo Siemens, a qual implementaria o acordo Brasil-Alemanha de 1975 e a qual necessitava de mercado consumidor amplo capaz de disponibilizar à empresa a escala necessária para tornar economicamente viável o método de jato centrífugo (jet-nozzle), desenvolvido pelo professor E. Becker ${ }^{101}$ (PATTI, 2013; WROBEL, 1986: 130). Esse método, ainda experimental, era a terceira opção de acordo com o Brasil, após o fracasso das tratativas com a França e a impossibilidade de a Alemanha transferir, sozinha, tecnologia oriunda da URENCO ${ }^{102}$.

vom Oktober 1982 Stellung nehmen, und zwar unter dem Aspekt der ,,Solidarität der Lieferländer”. (AA. 23 Feb. 1984).

${ }^{97}$ MRE 19 Abril 1971

${ }^{98}$ AA 7 jul. 1975.

99 “Unser Brasilien-Vertrag solte nicht als Maßstab für die weiteren Verträge über Lieferung sensitiver Anlagen mit anderen Ländern betracht warden. Wir sollten vielmehr unsere Bereitschaft zu aufgeschlossener Mitarbeit an einer gemeinsamen Exportpolitik der Lieferländer zum Austruck bringen und uns dabei behühen die Besorgnisse der USA auszuräumen” (AA 7. Jul. 1975).

${ }^{100}$ AA, 25 mai 1976

${ }^{101}$ BATISTA, 05 ago. 1982; AA, 13 jan. 1977

${ }^{102}$ AA, 13 jan. 1977; BATISTA, 11 nov. 1980 
Além disso, o interesse alemão no Brasil passava pela possibilidade de obter suprimentos confiáveis ${ }^{103}$ e regulares ${ }^{104}$ de urânio.

Fazia-se, portanto, parte precípua do interesse alemão negociar acordo que fosse atrativo para o Brasil, mesmo que isso significasse ceder ao país sul-americano knowhow necessário para implementar indústria nacional no país. Esse acordo deveria, contudo, atender às determinações internacionais impostas à República Federal, por exemplo, pelo GSN, da qual fazia parte, e pelos Estados Unidos. Washington, inclusive, tentou impedir a confecção do tratado, por meio de críticas à flexibilidade da postura alemã com relação ao Brasil ${ }^{105}$ e por meio da proposta do então assessor do Secretário de Estado para assuntos nucleares, Joseph Nye Jr., para que o Brasil trocasse o desejo de possuir uma usina de enriquecimento urânio pelo compromisso norte-americano de abastecer os reatores brasileiros (WROBEL, 1986: 136).

As negociações para a confecção do Acordo Brasil-Alemanha de 1975 começaram no ano anterior, na esteira da mudança conjuntural do regime internacional de não proliferação nuclear ocasionada pela explosão indiana. O Brasil, agora sob a administração Geisel, havia iniciado plano para a diversificação da matriz energética nacional, o qual incluía o "Plano 90" (PATTI, 2013: 182), pelo qual a Eletrobrás havia calculado a necessidade de expansão da estrutura energética brasileira com base em previsões de consumo para o ano de 1990, conforme anteriormente exposto.

Com base nos cálculos feitos pelo governo quando da definição da opção nuclear brasileiro de longo prazo, o Brasil apresentou, nas negociações com Bonn, a intenção de construir 8 novas usinas nucleares, as quais, acreditava-se, seriam suficientes para suprir, juntamente com a energia hidroelétrica e a expansão, em menor escala, de outras fontes como o carvão, as necessidades de crescimento energético das regiões Sul e Sudeste $^{106}$. Segundo o plano, acordado com a KWU, as usinas deveriam ficar prontas até o ano de 1990 e possuir uma capacidade conjunta, somando-se as usinas de origem alemã com Angra I, de 10.200 MW, conforme demonstrado no Quadro 4.

\section{Quadro 4 - Programa Nuclear das Regiões Sul e Sudeste}

\footnotetext{
${ }^{103}$ Como já se sabia desde a década de 1950, o Brasil possui relevantes reservas de urânio localizadas em regiões como a cidade de Caetité, na Bahia. Atualmente, calcula-se que as reservas brasileiras de urânio somem 310 mil toneladas (MARIN, 2010).

${ }^{104}$ Motivações da Alemanha Federal para o acordo com o Brasil incluiriam: “- maintain its reputation as a high-quality supplier of nuclear technology and Equipment; - gain access to Brazilian uranium deposits; preserve good relations generally with South America's largest country" (CIA, 21 out. 1983).

${ }^{105}$ AA 7 jul. 1975

${ }^{106}$ Essa proposta e esse cálculo foram expostos no Gráfico 1.
} 


\begin{tabular}{lllll}
\hline Usinas & Capacidade & Construção (ano) & Prazo total & Origem da tecnologia \\
\hline Angra I & $600 \mathrm{MW}$ & - & - & Estados Unidos \\
Angra II & $1200 \mathrm{MW}$ & $1977-1981$ & Até 1977 & Alemanha \\
Angra III & $1200 \mathrm{MW}$ & $1 / 21978 \frac{1}{2} 1983$ & 7,5 anos & Alemanha \\
Usina IV & $1200 \mathrm{MW}$ & $1981-1985$ & 7,5 anos & Alemanha \\
Usina V & $1200 \mathrm{MW}$ & $1982-1986$ & 7,5 anos & Alemanha \\
Usina VI & $1200 \mathrm{MW}$ & $1983-1987$ & 7,5 anos & Alemanha \\
Usina VII & $1200 \mathrm{MW}$ & $1984-1988$ & 7,5 anos & Alemanha \\
Usina VIII & $1200 \mathrm{MW}$ & $1 / 21984 \frac{1}{1} 21989$ & 7,5 anos & Alemanha \\
Usina IX & $1200 \mathrm{MW}$ & $1 / 219851 / 21990$ & 7,5 anos & Alemanha \\
\hline
\end{tabular}

Fonte: Senado Federal, 1982. Elaboração Própria.

Cabe lembrar que, conquanto o plano de produção de energia tenha sido firmado junto ao acordo final com a Alemanha, questões internas de ordem econômica e mudanças conjunturais no sistema internacional, melhor analisadas no capitulo 3 , levaram o Brasil a descontinuar o cronograma inicialmente proposto, de modo que, hodiernamente, apenas a usina de Angra II se encontra operacional. De fato, pode-se considerar que o programa de longo prazo do governo não foi exitoso para o setor nuclear, porquanto o crescimento contínuo esperado do setor nuclear para o período de duas décadas não se realizou. Enquanto se esperava, até o ano de 2000, o Brasil contasse com a produção de 81.227 MW acumulados oriundos de 10 usinas nucleares, a produção acumulada naquele ano foi de, tão somente, $11.889 \mathrm{MW}$, advindos de 2 usinas, as quais eram responsáveis por $0,1 \%$ da produção nacional ${ }^{107}$.

As negociações iniciadas com a Alemanha Federal, em 1974, foram sistematizadas no Protocolo de Brasília de 1974, o qual abarcava seis pontos que o Brasil considerava essenciais no esquema de cooperação bilateral:

a. cooperação para a criação de indústria de reatores nucleares;

b. tecnologia para prospecção e exploração de urânio;

c. conversão de Hexafluoreto de Urânio (UF6) ${ }^{108}$;

\footnotetext{
107 A comparação entre as previsões iniciais e os resultados verificados para o crescimento do setor nuclear entre os anos de 1979 e 1980 pode ser verificada na tabela Anexo 4.

108 O UF6 trata-se de composto advindo do yellow cake (pós de urânio) utilizado no processo de separação isotópica (enriquecimento) de urânio, o qual produz combustível para reatores e para armamentos nucleares.
} 
d. enriquecimento de urânio;

e. fabricação de elemento combustível para reatores;

f. reprocessamento do combustível irradiado. ${ }^{109}$

Além disso, previu-se mecanismo para implementação de salvaguardas internacionais em todo o ciclo produtivo do urânio, o qual será implementado, posteriormente, por meio tanto do acordo trilateral Brasil-Alemanha-AIEA, celebrado em 1976, nos mesmos moldes do acordo trilateral Brasil-Estados Unidos-AIEA, de 1972, ${ }^{110}$ quanto por meio do Acordo Brasil-Alemanha sobre usos pacíficos da energia nuclear, de 1976. Ao passo que o acordo trilateral foi considerado por Bonn condição essencial para a assinatura do Acordo de 1975, porquanto compatibilizava a cooperação com o Brasil e os compromissos assumidos com o TNP ${ }^{111}$, o Acordo de 1976 tratou-se de instrumento que vinculava, inequivocamente, o programa nuclear brasileiro ao sistema de salvaguardas alemão. Pelo artigo $3^{\circ}$ deste acordo, inclusive, as partes concordaram em implementar sistema de conhecimento mútuo, segundo o qual toda exportação para terceiros países de material oriundo da cooperação bilateral deverá ser comunicado à outra parte e salvaguardado pela IAEA ${ }^{112}$.

Outro ponto importante, previsto no Protocolo de Brasília de 1974, é a transferência tecnológica para fabricação de combustível nucelar e a instalação imediata, pela KWU e pela Nuclebrás, de fábrica piloto no Brasil, com o objetivo de iniciar o processo de transferência tecnológica. A usina piloto deveria ser transformada em usina para escala industrial por volta de 1980 e deveria garantir, também, recarga de urânio enriquecido para a usina de Angra $\mathrm{I}^{113}$. Essa construção foi exitosa, embora a tecnologia não tenha sido complementa absorvida pelo Brasil, devido à inviabilidade econômica do uso do processo de jato centrífugo para fins comerciais.

Em 1975, ao celebrar o Acordo Nuclear Brasil-Alemanha, ambos os países consolidaram e aprofundaram aquilo previsto no Protocolo de Brasília e definiram a transferência completa do know-how sobre o enriquecimento do urânio, com a implementação, no Brasil, de tecnologia capaz de garantir autossuficiência do país com relação a todas as fases do ciclo combustível nuclear. Além disso, criar-se-ia joint-

\footnotetext{
${ }^{109}$ SF, 1982, p. 117.

${ }^{110}$ DEUTSCHER BUDESTAG, 01 abr. 2014; DEUTSCHER BUNDESTAG, 30 nov. 1993; SF, 1982, p. 125 e 247

${ }^{111}$ AA 14 fev. 1975

${ }^{112}$ BRASIL, ALEMANHA, 26 fev, 1976

${ }^{113} \mathrm{SF}, 1982$, p. 118-119
} 
venture teuto-brasileira para a prospecção de minérios estratégicos, com o objetivo de descobrir as reservas brasileiras de urânio e de tório - a qual, contudo, não chegou a ser operacionalizada e teve suas funções cedidas à NUCLAM. Conforme afirmou o Ministro de Minas e Energia, Shigeaki Ueki, na Comissão da Câmara dos Deputados sobre a questão nuclear (SF, 1982, p. 122), a exportação para a Alemanha Ocidental seria limitada a até $20 \%$ do urânio a ser descoberto pela binacional, apesar de o acordo abrir margem para que os Bonn exigisse obter conhecimento de todas as reservas de material radiativo existentes no Brasil.

Do Acordo Brasil-Alemanha foi constituído arcabouço de 4 empresas binacionais, porém todas majoritariamente controladas pela Nuclebrás, e 1 empresa brasileira auxiliar na construção de usinas nucleares (a NUCON). Essas quatro empresas, NUCLAN, NUCLEN, NUCLEP, NUCLEMON, deveriam, como demonstrado pelo Quadro 4, abranger toda as áreas da produção de energia nuclear, desde a prospecção, com a NUCLAM e a NUCLEMON, até a comercialização de componentes pesados, com a NUCLEP.

Esse arcabouço seria, como também observado pelo Quadro 5, majoritariamente controlado pela Nuclebrás, o que consistia de exigência do governo brasileiro para manter o controle sobre tecnologia sensível e relacionada à segurança nacional. Do lado alemão, o acordo seria coordenado pela KWU, porém envolveria, seis empresas, das quais duas austríacas - a Vereinigte Österreichische Eisen AG (VÖEST) e a Gutehoffnungshütte Sterkrade AG (GHH), na área de desenvolvimento de componentes pesado -, e quatro alemãs - a KWU, a INTERATOM, a AREVA e a STEAG Kernenergie GmBH . Sobre a presença de empresas austríacas, vale salientar que Viena desenvolvia política nuclear bastante próxima de Bonn, tanto no setor de desenvolvimento tecnológico quanto de comercialização, dado que a ambos os países sofreram limitações similares ao enriquecimento de urânio em seus territórios e que, no final da década de 1960, quando o governo austríaco optou por construir usinas nucleares próprias, a alternativa escolhida foi a KWU.

Em consonância com o ideal comercialista da política alemã de cooperação nuclear, parte crucial do sonderweg, o acordo de 1975 previa amplo financiamento para o projeto com o Brasil. A financiamento advindo do exterior para projetos de infraestrutura nacionais coadunava-se com a estratégia brasileira de crescimento econômico previsto nos três PNDs. O financiamento de 1,85 milhões de marcos alemães seria concedido por um consórcio internacional composto por dois bancos 
comerciais, o Commerzbank AG e o Deutsche Bank AG, os quais arcariam com 70\% dos custos, e por quatro bancos regionais, o Dresdner Bank AG, o Bayerisch Hypotheken- und Wecksel- Bank, o Bayerisch Landesbank Girozentrale e o Westdeutsche Landesbank Girozentrale, os quais arcariam com $30 \%$ do total.

\section{Quadro 5 - Arcabouço Institucional Introduzido Pelo Acordo Brasil-Alemanha}

\begin{tabular}{|c|c|c|c|c|c|c|c|}
\hline $\begin{array}{l}\text { Empresas } \\
\text { Binacionais }\end{array}$ & $\begin{array}{l}\text { Anos de } \\
\text { Criação e } \\
\text { de } \\
\text { Extinção }\end{array}$ & Atividades & Metas e meios & $\begin{array}{c}\text { Participação } \\
\text { estrangeira }\end{array}$ & $\begin{array}{c}\text { Participação } \\
\text { nacional }\end{array}$ & $\begin{array}{c}\text { Capital } \\
\text { Autorizado }\end{array}$ & $\begin{array}{l}\text { Financiamento } \\
\text { Total }\end{array}$ \\
\hline $\begin{array}{l}\text { NUCLAM } \\
\text { (Nuclebrás } \\
\text { Auxiliar de } \\
\text { Mineração } \\
\text { S.A.) }\end{array}$ & $\begin{array}{l}1975- \\
1988\end{array}$ & $\begin{array}{l}\text { Prospecção, } \\
\text { pesquisa e lavra } \\
\text { de urânio. }\end{array}$ & $\begin{array}{c}\text { - Exploração em } 2 \text { áreas, } \\
\text { medindo, conjuntamente, } \\
73.000 \mathrm{~km}^{2} \\
\text { - venda comprometida de } \\
\text { 20\% de qualquer minério } \\
\text { descoberto à RFA }\end{array}$ & $\begin{array}{c}49 \% \\
\text { (Urangesellschaft } \\
\text { - UG, AREVA) }\end{array}$ & $\begin{array}{c}51 \% \\
\text { (Nuclebrás) }\end{array}$ & $\begin{array}{c}\text { Cr\$ } \\
100.000 .000\end{array}$ & \multirow{6}{*}{$\begin{array}{l}\text { Consórcio: } \\
\text { Dresdner Bank } \\
\text { AG } \\
\text { (cordenador), } \\
\text { Bayerisch } \\
\text { Hypotheken- } \\
\text { und Wechsel- } \\
\text { Bank; } \\
\text { Bayerisch } \\
\text { Landesbank } \\
\text { Girozentrale; } \\
\text { Commerzbank } \\
\text { AG; Deutsche } \\
\text { Bank AG; } \\
\text { Westdeutsche } \\
\text { Landesbank } \\
\text { Girozentrale. } \\
\text { Composição: } \\
\text { Bancos } \\
\text { Comerciais } \\
\text { (Commerzbank } \\
\text { AG; Deutsche } \\
\text { Bank AG); 70\% } \\
\text { Bancos } \\
\text { Regionais: } \\
\text { 30\%. } \\
\text { Valor: DM 1,85 } \\
\text { milhões, } \\
\text { garantido pelo } \\
\text { Ministério da } \\
\text { Fazenda e pela } \\
\text { KWU. }\end{array}$} \\
\hline $\begin{array}{l}\text { NUCLEN } \\
\text { (Nuclebrás } \\
\text { Engenharia } \\
\text { S.A.) }\end{array}$ & 1975- & $\begin{array}{l}\text { Projeto e } \\
\text { serviços de } \\
\text { engenharia para } \\
\text { usina nuclear. }\end{array}$ & $\begin{array}{l}\text { - } 4 \text { unidades tipo PWE } \\
\text { com potência de } 1.300 \\
\text { MWE cada, em } 1985 \\
\text { - } 4 \text { outras unidades, em } \\
\text { torno de } 1990, \text { com } \\
\text { participação crescente da } \\
\text { indústria nacional }\end{array}$ & $\begin{array}{l}25 \% \text { (Kraftwerk } \\
\text { Union AG - } \\
\text { KWU) }\end{array}$ & $\begin{array}{c}75 \% \\
\text { (Nuclebrás) }\end{array}$ & $\mathrm{Cr} \$ 30.000 .000$ & \\
\hline $\begin{array}{c}\text { NUCLEP } \\
\text { (Nuclebrás } \\
\text { Equipamentos } \\
\text { Pesados S.A.) }\end{array}$ & 1975- & $\begin{array}{l}\text { Desenvolviment } \\
\text { o, fabricação e } \\
\text { comercialização } \\
\text { de componentes } \\
\text { pesados. }\end{array}$ & $\begin{array}{c}\text { - Fabricação de } \\
\text { combustíveis maiores em } \\
1985\end{array}$ & $\begin{array}{c}0,6 \% \text { KWU; } 0,6 \% \\
\text { Vereinigte } \\
\text { Österreichische } \\
\text { Eisen AG } \\
\text { (VÖEST); } 0,6 \% \\
\text { Gutehoffnungshüt } \\
\text { te Sterkrade AG } \\
\text { (GHH) }\end{array}$ & $\begin{array}{c}98 \% \\
\text { (Nuclebrás) }\end{array}$ & $\begin{array}{c}\mathrm{Cr} \$ \\
292.800 .000\end{array}$ & \\
\hline $\begin{array}{l}\text { NUCLEI } \\
\text { (Nuclebrás } \\
\text { Enriqueciment } \\
\text { o Isotópico } \\
\text { S.A.) }\end{array}$ & $\begin{array}{c}1975- \\
1988\end{array}$ & $\begin{array}{c}\text { Produção de } \\
\text { Urânio } \\
\text { Enriquecido. } \\
\text { Construir usina } \\
\text { de } \\
\text { enriquecimento } \\
\text { de urânio com a } \\
\text { da tecnologia de } \\
\text { jato centrífugo. }\end{array}$ & $\begin{array}{c}\text { - Usina de demonstração } \\
\text { do processo de Jato- } \\
\text { Centrífugo com } \\
\text { capacidade de produzir } \\
\text { 230.000 UST/ano em } \\
1981 \\
\text { - Usina Comercial (2 ou } \\
\text { 3.000.000 UTS/ano) mais } \\
\text { tarde }\end{array}$ & $\begin{array}{c}15 \% \\
\text { Atomreaktorbau } \\
\text { GmbH } \\
\text { (INTERATOM); } \\
\text { 10\% STEAG } \\
\text { Kernenergie } \\
\text { GmBH }\end{array}$ & $\begin{array}{c}75 \% \\
\text { (Nuclebrás) }\end{array}$ & $\begin{array}{c}\text { Cr\$ } \\
700.000 .000\end{array}$ & \\
\hline $\begin{array}{l}\text { NUCLEMON } \\
\text { (Nuclebrás de } \\
\text { Monazita e } \\
\text { Associados S. } \\
\text { A. ) }\end{array}$ & $\begin{array}{c}1975- \\
1988\end{array}$ & $\begin{array}{l}\text { Continuar as } \\
\text { explorações de } \\
\text { areias } \\
\text { monazíticas } \\
\text { para a extração } \\
\text { de urânio e de } \\
\text { tório. }\end{array}$ & $\begin{array}{l}\text { - Usina Piloto e, } \\
\text { posteriormente, Usina } \\
\text { Comercial (Construção a } \\
\text { cargo da KWU) e Reactor } \\
\text { Brennelement Union } \\
\text { Cmbh KWU (RBU) }\end{array}$ & KWU (30\%) & $\begin{array}{c}70 \% \\
\text { (Nuclebrás) }\end{array}$ & - & \\
\hline $\begin{array}{l}\text { NUCON } \\
\text { (Nuclebrás } \\
\text { Construtora } \\
\text { de Centrais } \\
\text { Nucleares } \\
\text { S.A.) }\end{array}$ & $\begin{array}{c}1980- \\
1984\end{array}$ & $\begin{array}{l}\text { Auxiliar na } \\
\text { construção de } \\
\text { centrais } \\
\text { nucleares. }\end{array}$ & $\begin{array}{l}\text { - Usina Piloto com } \\
\text { capacidade para } 10 \mathrm{~kg} \text { de } \\
\text { metal pesado/ dia }\end{array}$ & $\begin{array}{c}\text { Assistência } \\
\text { técnica: Kern- } \\
\text { Emenstoffwtdenic } \\
\text { a Gesellshaft mbh } \\
\text { (KEWA); } \\
\text { Friedrich Uhde } \\
\text { Gmbh }\end{array}$ & $\begin{array}{c}100 \% \\
\text { (Nuclebrás) }\end{array}$ & - & \\
\hline
\end{tabular}


Fontes: BRASIL. Cooperação nuclear Brasil-República Federal da Alemanha - constituição de empresas subsidiárias na Nuclebrás. Arquivo Paulo Nogueira Batista. CPDOC-FGV. Sem Data; Discurso de Peter Von Siemens, In.: Livreto Programa Nuclear Brasileiro: Governo Presta Contas, secretaria de comunicação social da presidência da república, 1981; FURNAS. Furnas-Centrais Elétricas S.A. Financing of the Angra dos Reis II and III Nuclear Power Plants. Arquivo Paulo Nogueira Batista. CPDOC-FGV. jun. 1976. Elaboração Própria.

Apesar dos esforços alemães e brasileiros de desenvolver instrumental de salvaguardas que, acreditavam seus governos, deveria garantir ampla aceitação da comunidade internacional, o Acordo Brasil-Alemanha de 1975 levou a reações negativas de países como Estados Unidos. Em diversas frentes, desde tratativas bilaterais com Bonn e Brasília até incursões contra o acordo em meio ao GSN, Washington tentou barrar a consecução do acordo bilateral de 1975, justificando para isso que a Alemanha estava contribuindo com a proliferação de armas nucleares, ao transferir tecnologia de enriquecimento de urânio para país não parte do $\mathrm{TNP}^{114}$.

Às reações americanas, o Brasil e a Alemanha responderam incisivamente, afirmando a soberania e o direito de países em desenvolvimento adquirirem tecnologia nuclear para fins pacíficos ${ }^{115}$. O Brasil, em especial, declarou que continuaria seus problemas "apesar de das ameaças e represália dos Estados Unidos" (DEPARTMENT OF STATE, 19 nov 1976, tradução própria). ${ }^{116}$ A questão nuclear demonstrou, dessa forma, claro exemplo do movimento do afastamento entre Brasil e Estados Unidos verificado durante o governo claro, demonstrando postura mais crítica de Brasília com relação a Washington e mais incisiva na defesa das alternativas àquele país. De fato, a tom da postura brasileira chegou a tal ponto que um funcionário não nomeado chegou, inclusive, a afirmar que os americanos estavam sendo mais prejudiciais aos interesses brasileiros até mesmo do que os soviéticos ${ }^{117}$.

Grandemente incitados pela postura americana, outros países também criticaram o Acordo de 1975, afirmando ser ele prejudicial aos esforços multilaterais de não proliferação nuclear. A própria União Soviética teria pressionado a Alemanha Federal a

\footnotetext{
${ }^{114}$ AA, 23 Fev. 1984

115 "Our nuclear program will continue, at least to the extent it depends on us, against all internal and external pressures. The Germans know that we acted with seriousness in signing the agreement. We do not want the atomic bomb. We want to be independent, to construct our future, and to prevent (the effects of) any future world petroleum and energy crisis. Brazil will not give way." (DEPARTMENT OF STATE, 19 nov. 1976

${ }^{116}$ DEPARTMENT OF STATE, 19 nov. 1976

117 "The US Embassy in Brazil quotes a Brazilian ministry official who declares Brazil will continue its nuclear program "despite all the threats and reprisals" from the US. The unnamed official goes on to say, 'The Americans, our allies, are behaving in a way worse than that of our common enemies, the Russians"” (DEPARTMENT OF STATE, 19 nov. 1976).
} 
não firmar o acordo ${ }^{118}$, ao passo que, em conversa com o embaixador americano em Paris, representantes do Quai d'Orsay se mostraram preocupados com a possibilidade de proliferação de armas nucleares na América Latina ${ }^{119}$. Os diplomatas franceses chegaram, inclusive, conferir se os americanos estavam pressionando o Brasil e a Alemanha Federal contra o acordo nuclear ${ }^{120}$. Com relação à França e à União Soviética, contudo, as posturas brasileira e alemã foram menos incisivas do que em relação à americana, porquanto Moscou era vista, no ambiente da Guerra Fria, como inimiga e Paris também era acusada de instar a proliferação nuclear ${ }^{121}$, devido à proximidade que desenvolvia no setor atômico com o governo de Islamabad ${ }^{122}$.

O Acordo Nuclear Brasil-Alemanha foi abandonado, parcialmente, pelos governos de ambos os países e substituído por novo acordo em 1994, e sua estrutura institucional, como exposto no Quadro 4, progressivamente desmantelada na década de 1980. Apesar disso, esse acordo levou o Brasil a obter os insumos necessários para desenvolvimento de tecnologia nuclear nacional e permitiu formação de equipe profissional apta a atuar na área nuclear, além de resultar na construção da segunda e da terceira (em processo) usina nuclear brasileiras, na Central Nuclear Almirante Álvaro Alberto. Além disso, o acordo coroou período de aproximação e de construção de confiança nas relações com a República Federal, que se delineava desde Médici. Essa aproximação pode ser exemplificada pela decisão do chanceler Mário Gibson Barbosa de permitir a entrada do navio nuclear germânico Otto $\mathrm{Habn}^{123}$ no mar territorial brasileiro ${ }^{124}$.

As relações com a República Federal no campo nuclear serão, progressivamente, arrefecidas na década seguinte, no governo Figueiredo, quando o Brasil optará por

\footnotetext{
${ }^{118}$ MRE, 21 mar. 1977

${ }^{119}$ DEPARTMENT OF STATE, 23 set. 1978

120 "while source deplored the proliferation possibilities in Latin America if Brazil were to make a bomb, he said that France, not being a party to the contract [with the KWU], was in no position to oppose it at this point. In any case, France has little leverage on Brazil, while the US (he [the French representative] added) has much more. He asked if the US had recently expressed its concern to the FRG [Federal Republic of Germany] or to Brazil, we answered that it has done so in the past" (DEPARTMENT OF STATE, 23 set. 1978).

${ }^{121}$ DEPARTMENT OF STATE, 23 set. 1978

122 "Wir rechtfertigen unsere Lieferbeziehungen zu Argentinien un Brasilien letzten Endes damit, dass wie dort vorerst (for the time being) nicht mit dem Entstehen (arise) von Kernwaffenstaaten rechnen. In Pakistan stehen wir vor dem Problem, den pakistanischen Wunsch nach einem KKW in Einklang (harmony) zu bringen mit unseren Beziehungen zu den USA und Frankreich (und evtl. Indien).“(AA 23 Fev. 1984)

${ }^{123}$ MRE, 27 Jul. 1972

${ }^{124}$ Deve-se lembrar que posteriormente, no governo de Fernando Collor, o Brasil exigirá que todos os navios e submarinos de propulsão nuclear fossem examinados por agentes da CNEN, o que quase gerou conflito de interesse com os Estados Unidos, pois esses recusavam-se a abrir submarinos nucleares aos inspetores brasileiros. Essa informação foi concedida ao autor por entrevista concedida pelo Funcionário CNEN 1.
} 
concentrar seus esforços no desenvolvimento autônomo de energia nuclear, por meio do então chamado Programa Nuclear Paralelo. Esse processo consistirá de nova e mais profunda inflexão na política externa de cooperação nuclear brasileira e levará o país a vislumbrar possíveis parcerias com países como Iraque, partícipe da Rede-Khan, a qual constituiu mercado negro, incitado pelo cientista paquistanês Abdul Khan, para a compra de tecnologia nuclear para fins bélicos ${ }^{125}$, a partir de tecnologia roubada da empresa URENCO.

\subsection{O início da desilusão: a URENCO e as exigências inglesas e holandesas}

Apesar de o Brasil ter contratado com a Alemanha Federal a transferência de tecnologia nuclear por jato centrífugo, um método custoso e complexo ainda em fase experimental, Brasília não desistiu de obter da Alemanha Federal a tecnologia comprovadamente eficiente da URENCO, bem como de obter urânio enriquecido daquele consórcio. Bonn também manteve o interesse em ampliar os laços cooperativos com o Brasil no setor nuclear, de modo que continuou a negociar com seus parceiros ingleses e holandeses a possibilidade de negociação de acordo entre a URENCO e Brasília. Enquanto o Brasil tinha interesse em obter, no curto prazo, tecnologia confiável para enriquecimento de urânio, a Alemanha queria ampliar, ainda mais, sua fatia no mercado mundial nuclear e obter maiores ganhos econômicos.

Já em 1978, após o início do processo de operacionalização do acordo de 1975, a tecnologia de jato centrífugo começou a aparentar ser opção pouco viável para produção energética em escala comercial. Nesse contexto, enquanto o Geisel e Azeredo da Silveira analisavam os possíveis benefícios a serem obtidos de uma adesão brasileira ao $\mathrm{TNP}^{126}$, o Auswärtige Amt continuava a buscar apoio de seus parceiros na URENCO. A Inglaterra, o primeiro parceiro a ser procurado pelo Brasil e pela Alemanha, mostrou-se aberta à transferência de tecnologia ${ }^{127}$ e de urânio enriquecido ao Brasil, desde que com as devidas providências relativas à implementação de salvaguardas fossem tomadas. Para Londres, essas providências faziam-se necessárias, na medida em que se deveria

\footnotetext{
125 Vale salientar, conforme lembra Harnisch (2005), que o os únicos países que, reconhecidamente, obtiveram algum tipo de tecnologia por meio da Rede Kahn foram Paquistão, Coreia do Norte, Líbia, Irã e Iraque. Não há documentação que conecte o Brasil a essa rede.

${ }^{126}$ MRE, 23 fev. 1978

${ }^{127}$ BATISTA, 15 set. 1977
} 
evitar que o Brasil acumulasse plutônio ${ }^{128}$, assunto especialmente relevante para a comunidade internacional após a explosão indiana ${ }^{129}$.

Nesse sentido, o Foreign Office britânico afirmou que exigiria de um futuro acordo com o Brasil poder de veto sobre "quaisquer atividades" desenvolvidas na usina de enriquecimento de urânio e na provável usina de reprocessamento de plutônio construídas no Brasil (AA, 22 mar. 1977, p. 70). Essa exigência foi considerada inaceitável para o Brasil, porquanto feria o interesse nacional em área considerada estratégia. Também para a Alemanha a exigência britânica fora considerada inaceitável ${ }^{130}$, pois o poder de veto britânico poderia implicar ameaça de ingerência dos demais sócios da URENCO nas instalações construídas sob o arcabouço do Acordo de 1975 com a Nuclebrás. Além disso, Bonn temia que o veto britânico abrisse precedente para que os países fornecedores de urânio à URENCO, como o Canadá e a Austrália, passassem a exigir condições de veto semelhantes nos acordos firmados com a República Federal (ähnliche bedingungen von uns berlangen) ${ }^{131}$.

Apesar das dificuldades impostas pela Inglaterra, o maior problema no que concerne à possibilidade de acordo com a URENCO para fornecimento de urânio ao Brasil foi a Holanda ${ }^{132}$. O argumento de Amsterdã era que o Brasil deveria aderir ao TNP para que o a AIEA tivesse acesso total e irrestrito a todas as instalações nucleares brasileiras e que, sem essa adesão, o Brasil ainda poderia desenvolver uma bomba suja (a crude explosive device $)^{133}$. Essa postura decorria da comparação entre o Brasil e a Índia e do temor de que aquele desenvolvesse tecnologia nuclear para fins militares a partir de usinas não abarcadas pelos acordos bilaterais.

Apesar de a Alemanha ter garantido a Amsterdã que o acordo seguiria a política delimitada pelo GSN, a postura holandesa manteve o tom mais incisivo devido a questões de natureza interna. Essas questões envolviam, principalmente, a reação dos Estados Unidos contra o possível acordo a ser desenvolvido. Os Países Baixos temiam

\footnotetext{
${ }^{128}$ AA, 22 mar. 1977, p. 70

${ }^{129}$ Vale salientar que a bomba nuclear indiana, cujos testes ocorreram em 1974, foi desenvolvida com plutônio reprocessado de resíduos advindos de usinas nucleares internacionalmente salvaguardadas, cuja tecnologia fora obtida de acordos com os Estados Unidos e com a França (BRENNER, 2009, p. 114-115). ${ }^{130}$ AA, 22 mar. 1977

${ }^{131}$ AA, 22 mar. 1977, p. 70-71

132 AA, 12 jan. 1977; BATISTA, 15 set. 1977

133 " $\mathrm{Zu}$ dem niederländischen Argument, dass die aus dem Brasilien-Abkommen vermutete Proliferationsgefahr vermieden werden, wenn Brasilien dem NV-Vertrag betreite. müsse er sagen, dass auch bei totaler IAEO-Kontrolle ein Kernenergieland mit bestehenden Wiederaufarbeitungsanlagen innerhalb von sieben Studen - allerdings unter Bruch internationaler Verplichtungen - ein "crude explosive device" herstellen könnte" (AA, 12 jan. 1977, p. 4-5).
} 
que Washington, que já se opunha ao acordo bilateral Brasil-Alemanha de 1975, reagisse de forma negativa a um novo acordo com o Brasil, o que poderia contrariar os interesses holandeses, pois a URENCO estava em fase de implementação de um projeto de construção de usina de enriquecimento de urânio por tecnologia de centrifugação gasosa na cidade de Almelo, o noroeste da Holanda, a qual necessitaria de combustível oriundo dos Estados Unidos para funcionar. A Holanda, dessa forma, rejeitaria qualquer tratativa internacional que pudesse impedir esse projeto.

Embora o governo brasileiro tenha considerado negociáveis as exigências britânicas, as sucessivas barreiras criadas pelos holandeses à consecução de acordo para exportação de urânio enriquecido ao Brasil teriam mostrado, para o chanceler Azeredo da Silveira, que eles não seriam fornecedores confiáveis (Verläßlicher Verhandlungspartner ${ }^{134}$. Além disso, Azeredo da Silveira afirmou ao Ministro dos Assuntos Estrangeiros alemão, Hans-Dietrich Genscher, que, apesar de o Brasil não estar pressionado com o tempo, o governo brasileiro precisava ter certeza de que o material nuclear - e possível reator - fornecido pela URENCO seria entregue no prazo acordado $^{135}$. O chanceler brasileiro também teria afirmado, com relação às pressões de Washington, que o Brasil é país do Ocidente e que, em reunião com o Secretário de Estado Cyrus Vance, ele teria garantido que o Brasil não realizou nem realizaria “proliferação intelectual” (cessão de conhecimento necessário para o desenvolvento de artefatos nucleares) e que todo o programa brasileiro estaria sujeito a salvaguardas, além do que pesquisas com o ciclo do tório também seriam de interesse dos Estados Unidos $^{136}$.

Apesar de continuar a insistir no acordo com os paises do Eixo Assimétrico , os cometários de Azeredo da Silveira demonstram desilusão com os países do Norte Global, motivada pela difuldade impostar pelos ingleses e holandeses de cooperar no setor nuclear, pela pouca viabilidade do processo de enriquecimento de urânio por jato centrífugo e pelas pressões norte-americanas contrárias a qualquer cooperação nuclear envolvendo o Brasil. Nesse contexto, o governo Geisel começou a perceber que não obteria êxito em desenvolver seu program nuclear por meio da cooperação internacional e passou, portanto, a aventar a possibilidade de desenvolvimento de programa nuclear

\footnotetext{
${ }^{134}$ AA, 6 mar. 1978, p. 68

${ }^{135}$ AA, 6 mar. 1978

${ }^{136}$ AA, 6 mar. 1978
} 
autônomo para obtenção autóctone de tecnologia de enriquecimento de urânio ${ }^{137}$. Embora o programa autônomo somente tenha sido implementado no governo Figueiredo, sua gestação já começara, dessa maneira, nas desilusões ocorridas ao final da gestão de Geisel no Planalto.

\section{O Eixo Regional: a Argentina e a afastamento brasileiro do regime internacional de não proliferação nuclear}

Apesar de o principal Eixo da política nuclear durante os governos Médici e Geisel ter sido aquele aqui denominado Eixo Assimétrico, faz-se relevante também fazer nota sobre o chamado eixo auxiliar, o qual influiu, embora de modo menos determinante, na política nuclear brasileira entre 1969 e 1978. Esse eixo é o Regional, com a Argentina. Cabe lembrar que, embora já houvessem sinais de surgimento de um Eixo Sul no governo Geisel, como se mostrará no capítulo seguinte, esse eixo somente tornou-se relevante a partir da administração Figueiredo, de modo que se optou por não abordá-lo neste capítulo.

Diferentemente do Eixo Sul, o Eixo Regional foi uma constante da política nuclear brasileira desde os primórdios, porquanto a Argentina ocupa, historicamente, lugar de destaque nas preocupações externas brasileiras. Isso porque a Argentina, desde o período da independência, disputa com o Brasil hegemonia no subcontinente da América do Sul. Essa disputa, herdada das potências coloniais portuguesa e espanhola (CERVO, BUENO, 2011), motivou a formação de rivalidade entre os dois maiores países sul-americano pela busca de obter maior quantidade de insumos de poder.

Durante as décadas de 1960 e de 1970, a Argentina passava por momento de intensas modificações da estrutura econômica, do país, com mudanças sucessivas de diretrizes e de oscilações entre a ênfase no industrialismo e na vocação agrária (DE TITTO, 2008), bem como grande instabilidade política ${ }^{138}$ e alternâncias constantes entre militares e civis na Casa Rosada. A Argentina, que chegara a ser a quarta economia do mundo no início do século XX, chegou à década de 1960 em situação crítica tanto interna, com o quase colapso de sua matriz industrial, quanto externamente, enfrentando situação de quase belicosidade com o Chile e, em menor escala, com o Brasil

\footnotetext{
${ }^{137}$ BATISTA, 11 jun. 1975; MME, 17 jan. 1979.

${ }^{138}$ Vale lembrar que, entre 1966 e 1989, país teve 12 presidentes.
} 
(ESCUDÉ, 2005). No campo político, governos que se alternavam na presidência buscavam impor planos de estabilização macroeconômica de fisionomias variadas, desde a ortodoxia e o acordo com investidores do general Juan Carlos Onganía até o plano de pacto social de Juan Perón (ROMERO, 2002), passando pelo momento de desagregação político-econômica de Isabel Perón e o incentivo ao agronegócio e ingerência no campo trabalhista, nos governos militares de Videla, Viola, Galtieri e Bignone.

Apesar da instabilidade do ambiente político, a estratégia de desenvolvimento nuclear argentina manteve constância nas décadas de 1960, 1970 e 1980, devido a fatores como a continuidade de gestão do corpo técnico da CNEA (WROBEL, REDRIK, 1998) e o sucesso da política de desenvolvimento tecnológico tanto de modo autônomo, com o programa de geração de energia por urânio natural ${ }^{139}$ e de urânio enriquecido, este em Pilcaniyeu, quanto pelo estabelecimento de cooperação com países como a França e o Canadá. Essa continuidade levou a Argentina a desenvolver tecnologia nuclear própria de modo mais rápido e mais eficiente que o Brasil ${ }^{140}$.

Apesar de os países não terem feito opção clara pelo desenvolvimento de arsenais nucleares, ao menos na década de 1970, a diferença de capacidades era um fator passível de ser considerado no cálculo estratégico de ambos os países (GALL, 1976). A disparidade entre Brasil e Argentina, favorável a esta, era verificada tanto na área de desenvolvimento de tecnologia nuclear quanto na área de enriquecimento de urânio quanto na de desenvolvimento de possíveis desenvolvimento de mísseis balísticos para transportes de armas nucleares ${ }^{141}$. De fato, segundo a CIA, em 1982, a Argentina, diferentemente do Brasil, poderia, em um prazo de três anos, desenvolver armas nucleares $^{142}$ - visão esta que se contrasta com aquela exposta pelo MRE e pelo MME em 1974, segundo a qual a Argentina demoraria cerca de vinte anos para, caso optasse

\footnotetext{
${ }^{139}$ MRE, 04 Abril 1974, p. 6.

${ }^{140}$ MRE, 5 set. 1974

${ }^{141}$ CIA, 30 nov. 1967

142 "Argentina - but not Brazil - evidently could develop a nuclear weapon within three years. Both could probably complete weapon design and high explosive testing, however, within tree years. The availability of fissile material would determine the pace of production. (...) Argentina is likely to have its unsafeguarded reprocessing plant in operation this year. (...) Brazil does not have a suitable reactor or a reprocessing plant of any significant size. (...) The Argentine official previously has claimed that Buenos Aires already can develop nuclear weapons but does not intended to do so, and his latest statement appears to have been made for propaganda purposes. The reference to Brazil may be calculated to allay concern there regarding Argentina's fast paced nuclear development and its ultimate intentions." (CIA, 13 jan. 1982)
} 
por isso $^{143}$, produzir armamentos nucleares, devido a problemas financeiros, tecnológicos, e às salvaguardas existentes, no caso da tecnologia de água-pesada de Atucha, negociadas com o Canadá ${ }^{144}$.

A busca argentina por primazia no setor nuclear pode ser analisada sob dois prismas. Se, por um lado, aquele país poderia estar buscando compensar sua desvantagem no equilíbrio de poder regional, dadas as vantagens populacionais e de potencial hidrelétrico brasileiras ${ }^{145}$, por outro lado, o país, assim como o Brasil, necessitava desenvolver complexo energético eficiente. Neste último ponto, vale salientar que a Argentina não detinha o mesmo potencial hidrelétrico do Brasil e que grande parte de seu território é composto por regiões montanhosas ou de pouco potencial para aproveitamento energético, de forma que dominar a fissão atômica tornava-se elemento crucial na política energética argentina.

Independentemente da motivação argentina, a qual, acredita-se, deveria ou ser uma mescla das duas justificativas apresentadas (primazia geopolítica e desenvolvimento energético), ou ter-se modificado de acordo com as constantes mudanças na Presidência, o Brasil, em especial durante a gestão Geisel, não percebia com exagerado temor a presença argentina no Cone Sul. Isso ocorreria devido à percepção clara quanto ao declínio do poder argentino, percebido por Azeredo da Silveira (SPEKTOR, 2004), quanto pela "coincidência de opiniões na questão de não proliferação de armas nucleares" (SARAIVA, 2012, p. 48), ou seja, pelo discurso conjunto crítico às instituições internacionais de não proliferação existentes.

De fato, enquanto o governo Médici ainda visualizava na Argentina certo potencial de conflito, o governo Geisel passou a perceber vizinho com certo distanciamento e maior pragmatismo quanto a seu declínio econômico, ao passo que os governos posteriores, Figueiredo, Sarney, Collor, buscaram aproximar-se de Buenos Aires e criar cooperação estratégica (SARAIVA, 2012). Esta estratégia pode ser observada, por exemplo, na tentativa brasileira de expandir, no futuro, o acordo de 1975 para envolver fornecimento pela NUCLEP de urânio enriquecido à usina de Atucha ${ }^{146}$.

\footnotetext{
${ }^{143}$ Quanto à opção argentina por armas nucleares, possibilidade aventada pelo MRE (MRE, MME, 15 out. 1974) e temida por parte da opinião pública internacional (GALL, 1976), importante ressaltar que, em telegrama enviado à Presidência da República, os ministros Azeredo da Silveira e Shigeaki Ueki (MRE, MME, 15 out., 1974) consideraram a que o programa argentino tinha objetivos civis, diferentemente do indiano, e era suficientemente salvaguardado por meio de acordos com a AIEA, com os Estados Unidos e com o Canadá.

${ }^{144}$ MRE, MME, 15 out. 1974

${ }^{145}$ MRE, 5 set. 1974

${ }^{146} \mathrm{SF}, 1982$
} 
Isso não significa, contudo, que o Brasil tenha desconsiderado a Argentina na sua política de não proliferação nuclear. Após a explosão indiana, o temor de um teste de artefatos nucleares argentinos tornou-se elemento presente na política externa brasileira $^{147}$, pelo menos durante um breve momento. O próprio Azeredo da Silveira expressou extrema desconfiança com relação ao governo de Juan Perón ${ }^{148}$, em especial devido ao possível interesse deste em obter armas nucleares, o que estaria em consonância com as pretensões autonomistas da "terceira via". Porém, os temores mais exacerbados quanto ao belicismo argentino foram breves, pois o segundo governo Perón (12 out. 1973 - 1 jul. 1974) foi abreviado pela morte do presidente e sucedido por crise política ensejada pela pouca capacidade administrativa de sua vice (ROMERO, 2002), Isabel Perón.

Apesar de, depois do governo Perón, os temores brasileiros quanto à possível obtenção de armas nucleares pela Argentina terem-se reduzido, o Brasil continuou a manter certa cautela com relação ao país vizinho, por meio, por exemplo, da manutenção da recusa brasileira de assinar o TNP, até que a Argentina o fizesse e até que a crise hídrica Itaipu-Corpus, considerada urgente, fosse resolvida. Segundo anotações manuscritas feitas por Geisel em documento a ele enviado pelo ministro Azeredo da Silveira ${ }^{149}$, o qual aventava a possibilidade sugerida pelo engenheiro brasileiro Consetino, que havia recentemente visitado oficialmente a usina de Atucha, de estabelecer cooperação bilateral no campo nuclear com a Argentina ${ }^{150}$, o presidente brasileiro considerava que "há assuntos pendentes de inclinação entre Brasil e Argentina, inclusive da (ilegível) de Itaipu" e que um acordo de cooperação bilateral somente seria considerado caso após a solução das outras pendências.

Embora a Argentina tenha exercido menor influência, durante os governos Médici e Geisel, na política nuclear brasileira do que os países do Eixo Assimétrico , o papel do país vizinho foi relevante na definição de algumas estratégias nacionais. A percepção de possível rivalidade geopolítica e o temor quanto à produção de armas pelo governo Perón teriam sido elementos chave para entender o porquê da manutenção da política brasileira contrária ao TNP, apesar de indicativos de que a Presidência da República aventava a possibilidade de aderir àquele tratado, caso fosse necessário. Isso não

\footnotetext{
${ }^{147}$ MRE, 03 jun. 1974

${ }^{148}$ MRE, 03 jun. 1974

${ }^{149}$ MRE, 8 set. 1974

${ }^{150}$ Vale lembrar que as tentativas de formar acordo bilateral de cooperação já vinham desde antes, tendo, por exemplo, a CNEA tentando iniciar aproximação com o Brasil em 1972 (CNEA, 16 fev. 1972).
} 
significa comprovação da existência de uma corrida armamentista no Cone Sul durante o início da década de 1970, mas, apenas, que a Argentina possuiu função relevante na estratégia da política energética brasileira para o setor nuclear, em especial no governo Geisel, quando se aventou, inclusive, a possibilidade de criar arcabouço institucional com os alemães capaz de, no futuro, abarcar o parque nuclear argentino.

\section{Conclusões Parciais}

Durante a década de 1970, nos governos Médici e Geisel, verificou-se, no Brasil, a mudanças de meios no que concerne à busca de tecnologia nuclear pelo país. O aqui chamado Eixo Assimétrico acompanhou os rumos da política externa e da mudança conjuntural do sistema internacional. A cooperação com os Estados Unidos deu lugar à opção alemã, após o fracasso das tratativas com a França. Isso significou, também, mudança da estratégia brasileira de obtenção de tecnologia atômica. Enquanto Médici propugnou política de rápida transferência, para o Brasil, de reatores nucleares, de modo a instalar central nuclear operacional na região Sudeste, Geisel buscou alternativas que permitissem a transferência de tecnologia para a obtenção de know-how nacional sobre o ciclo do átomo.

Nesse processo, a Argentina desempenhou papel relevante, porém não crucial, na medida em que, os temores da nuclearização argentina com fins bélicos somente teriam tido espaço relevante durante o breve segundo governo de Juan Perón. De qualquer forma, a perspectiva de mudança de rumos do programa nuclear argentino na direção da obtenção de tecnologia dual contribuiu, de forma relevante, para que o Brasil optasse por manter a postura firme contrária ao TNP.

A mudança de perspectiva na política nuclear brasileira ocorreu tanto devido a fatores domésticos, como a mudança do grupo dos militares no Executivo Federal (ascensão dos castelistas) e mudança de tom da política externa (pragmatismo ecumênico e responsável), quanto por fatores internacionais, em especial o choque do petróleo, de 1973 e a mudança da política americana de não proliferação nuclear. Esses fatores levaram o Brasil a buscar alternativas ao acordo com a Westinghouse, das quais a mais vantajosa foi contratar com a Alemanha Ocidental e sua tecnologia experimento de jato centrífugo. Além de permitir ao Brasil obter tecnologia que seria desenvolvida nacionalmente, pela associação da Nuclebrás com a KWU, a opção alemã ainda 
aventava a possibilidade de obtenção futura da tecnologia de difusão gasosa da URENCO - cuja transferência ao Brasil foi grandemente dificultada pela Holanda e, em menor escala, pela Inglaterra.

Conquanto ambos os acordos nucleares não tenham atingido os objetivos inicialmente vislumbrados, o que levará o Brasil, nos governos Figueiredo-Sarney, a buscar desenvolver tecnologia nuclear de modo completamente autóctone, por meio do programa nuclear autônomo, eles representaram esforço nacional de diversificação da matriz energética brasileira. Além disso, cumpriu-se o objetivo inicialmente colocado de instalar, em território pátrio, as primeiras usinas atômicas, em Angra dos Reis. Acreditase, portanto, apesar de não sido totalmente exitosa, a política externa brasileira de cooperação nuclear da década de 1970 apresentou resultados positivos no médio e no longo prazos. 
Capítulo 3.

\section{Voltando-se para dentro (1979-1989): a emergência do Eixo Sul, a aproximação com a Argentina e o programa nuclear autônomo.}

\section{Introdução}

O período que se inicia em 1979 e termina em 1989, e que abrange os governos de João Figueiredo e de José Sarney, pautou-se por contexto interno de grandes modificações, tanto de ordem política quanto econômica, com a consolidação do processo de redemocratização doméstica e a intensificação de crise econômica decorrente de mudanças sistêmicas na conjuntura internacional e do aumento exorbitante dos juros da dívida externa. Esse cenário desfavorável, juntamente com a desilusão com o Eixo Assimétrico, países do Norte Global, e com a aproximação política com Buenos Aires, Eixo Regional, levou a mudança de rumos da política nuclear brasileira. Essa mudança foi, argumenta-se, no sentido de afastamento dos países do Eixo Assimétrico e de ênfase nas possibilidades de desenvolvimento autóctone de tecnologia atômica, para o que se vislumbrou maior proximidade com os países do Sul Global, Eixo Sul.

A mudança da política nuclear brasileira pode ser considerada efeito peremptório do esgotamento do modelo anteriormente adotado por Médici e por Geisel de cooperação com o Eixo Assimétrico, especialmente com os Estados Unidos e a Alemanha Federal, bem como consequência do colapso do modelo de crescimento econômico instado pelo alto endividamento externo e pela ascensão de novos grupos de poder na administração federal. O cansaço do modelo econômico implementado pelo regime militar ${ }^{151}$ desde a gestão Costa e Silva (CARNEIRO, 1995), impossibilitou a continuação do "Plano 90", o qual a construção de, pelo menos, nove usinas nucleares no Brasil até o ano de 1990. Esse processo também conformou no Brasil situação paradoxal na política nuclear: enquanto o país, no contexto macro-político, passava por abrangente liberalização e abertura a novos grupos, como demonstrado pela Lei da Anistia de 1979 e pelo retorno ao pluripartidarismo (lei 6.767/79), a política nuclear brasileira tornava-se cada vez

\footnotetext{
${ }^{151}$ Análise mais retida sobre a política econômica do "milagre" brasileiro pode ser encontrada no capítulo 2 desta dissertação.
} 
menos transparente e de aceso cada vez mais restrito a um grupo específico de burocratas e militares, partícipes do chamado programa nuclear autônomo ${ }^{152}$.

Isso ocorreu devido a dois fatores primordiais: de um lado, por conta da grande dificuldade orçamentária enfrentada pelo Brasil, decorrente dos aumentos globais das taxas de juros da dívida brasileira (GILPIN, 2001), a qual se compunha de contratos a taxas flutuantes; de outro, por conta do custo e da pouca viabilidade comercial futura da tecnologia de jato centrífugo, cuja transferência foi acordada com a Alemanha ${ }^{153}$. A esses fatores, deve-se acrescentar a mudança de grupos políticos no poder, em especial nas Forças Armadas e na $\mathrm{CNEN}^{154}$, nos quais se teria verificado a ascensão de grupos autonomistas $^{155}$, portanto favoráveis ao desenvolvimento de tecnologia atômica por vias autóctones. Apesar da redemocratização ocorrida em 1985, a política nuclear, no governo Sarney, manteve as mesmas diretrizes básicas daquela desenvolvida por Figueiredo $^{156}$ (VELÁZQUEZ, 2004), tendo demonstrado sinais de alteração somente ao final do mandato daquele presidente, em especial como consequência da pressão parlamentar decorrente da promulgação da nova constituição brasileira, em 1988, porém sem retirar aqueles grupos de suas posições ${ }^{157}$.

De modo a melhor analisar a mudança de enfoque da política nuclear brasileira durante o período dos governos Figueiredo e Sarney com relação ao período anterior, o presente capítulo divide-se em sete partes, sendo a primeira esta introdução. A segunda parte abarca a conjuntura interna e internacional na década de 1980, com ênfase nos elementos que influíram na política nuclear. A terceira parte analisa o programa nuclear autônomo, suas justificativas, estrutura e rumos. A quarta parte aborda a desilusão brasileira com o Eixo Assimétrico da política nuclear brasileira, ao passo que a quinta parte analisa as relações do Brasil com o Eixo Regional. A sexta parte abarca o Eixo Sul da política nuclear, e especial com a China, com a África do Sul, com o Iraque e com o México, enquanto a sétima parte consta de breve conclusão.

\footnotetext{
152 Embora o nome oficial do programa seja o "Programa Nuclear Autônomo" (CSN 21 fev. 1985), convencionou-se denomina-lo, também, de programa nuclear paralelo, conforme observado pela literatura e pelos documentos, Ambas as denominações são usadas de modo intercambiável.

${ }^{153}$ CN, 1990; CIA, 21 out. 1983

154 CIA, 8 set. 1986

155 Esses grupos seriam representados, por exemplo, pelo dr. Rex Nazaré Alves, na CNEN, e pelo Almirante Othon Pinheiro, na Marinha.

${ }^{156}$ CARVALHO 13 nov. 1984; CIA, 8 set. 1986

157 “Sarney's private views on whether Brazil ultimately should produce a nuclear device or even a weapon are not known. (...)Despite the advent of civilian government, the major policymaking figures remain the same, and the nuclear decision-making environment has not been significantly altered. Sarney pointedly retained the head $f$ the National Nuclear Energy Commission (CNEN) - - largely responsible for shaping recent nuclear efforts -- and, we believe, continues to support him" (CIA, 8 set. 1983).
} 


\section{A conjuntura interna e internacional (1978-1989)}

A década de 1980 pode ser caracterizada, no Brasil, como um período de relevantes modificações no contexto doméstico, as quais instaram alterações substanciais na política nuclear e energéticas brasileiras. Nesse período, se verificou ao processo de abertura política, retorno ao pluripartidarismo, à Lei da Anistia e à primeira eleição, em duas décadas, de um Presidente da República civil. Identificou-se também a processo de ascensão à cena política de diferentes grupos políticos oriundos de diferentes frentes contextos socioeconômicos - desde o novo sindicalismo, nascido no ABC paulista, até os grupos ligados ao agronegócio e aqueles ligados às federações estaduais de indústrias no congresso nacional (FAUSTO, 2012). Esses grupos políticos passaram a influenciar, de modo abrangente, as decisões políticas tomada governo nacional e, em especial no governo Sarney, passaram a exercer influência nos rumos da política nuclear brasileira, em particular nas negociações e do lobby na Assembleia Constituinte (BARLETTA, 1997; VELÁZQUES, 2004).

Essa abertura política ocorreu de modo simultâneo à intensificação da crise econômica verificada desde o governo Geisel, decorrente do fim do padrão ouro-dólar, em 1971 e dos choques do petróleo de 1973 e de 1979, os quais aumentaram o preço dos juros da dívida externa brasileira substancialmente. A primeira reação do governo federal, tanto de Geisel quanto de Figueiredo, ao eminente fracasso de sua estratégia econômica para o médio e longo prazo foi a manutenção dos métodos anteriormente verificados para estimular o crescimento econômico, como a manutenção da cessão de crédito facilitado a consumidores e investidores ${ }^{158}$ e o patrocínio ao crescimento industrial com capacidade ociosa (CARNEIRO, MODIANO, 1995).

Acreditava-se que a solução para os problemas externos enfrentados pelo Brasil seria o aumento da demanda, ou seja, da absorção interna dos produtos antes exportados, o que deveria prover o governo com divisas necessárias para o pagamento das dívidas externas, ao custo de leve aumento da inflação (CARNEIRO, MODIANO, 1995). Esse modelo começou a mostrar sinais de fracasso ainda no governo Figueiredo, com galopante aumento da inflação, com a recessão econômica e com a queda do volume das reservas internacionais. Esses problemas atingiram pico no governo Sarney, ao qual coube tentar resolver a crise por meio de sucessivos e pouco exitosos planos de

${ }^{158}$ BRASIL, 1980. 
controle inflacionário (Plano Cruzado, Cruzadinho, Cruzado II, Bresser, Feijão-comArroz, Verão).

Como parte do esforço de redução dos gastos públicos e de ajuste físcal vislumbrados pelos planos Bresser e Verão, o governo iniciou, também, no governo Sarney, processo de privatização de empresas consideradas pouco eficientes ou demasiadamente custosas aos cofres públicos. O plano de privatização, implementado em 1988, atingiu o arcabouço institucional criado pelo Acordo Brasil-Alemanha de 1975, levando à extinção da NUCLAN, da NUCLEI e da NUCLEMON, além da NUCON, que já havia tido suas atividades descontinuadas em 1984. Além disso, a própria Nuclebrás, pedra angular dos programas de cooperação com Washington e com Bonn, foi extinta em 1989. A justificativa principal para esse processo massivo de privatizações no campo nuclear foi aumentar a eficiência da administração pública e reduzir custos do custos de gestão do complexo nuclear brasileiro. Isso seria obtido por meio da extinção de empresas consideradas pouco relevantes, em especial após as desilusões enfrentadas com os alemães devido à pouca viabilidade comercial do método do jato centrífugo e ao fracasso das negociações para transferência de tecnológica da URENCO $^{159}$, e por meio da centralização da gestão das usinas energéticas brasileiras no sistema Furnas ${ }^{160}$-- Eletrobrás.

A maior eficiência da gestão do setor elétrico, seria relevante para administrar a crescente crise que atingia, no Brasil, além da econômica, a produção de energia. Uma das maiores para causas dessa crise foi o aumento substancial dos preços do petróleo importado, o principal motor da economia brasileira, em particular a partir do segundo choque do petróleo, em 1979, o qual representou o sepultamento definitivo da estratégia de crescimento brasileiro e o qual teria colocado o país em algo similar a uma “economia de guerra", segundo afirmou o próprio presidente Figueiredo, em 1980 (CASTRO SANTOS, 1993). Essa situação econômica levou à redefinição das prioridades do país em questões energéticas, o que implicou concentrar esforços na manutenção do crescimento da matriz hidrelétrica e o adiamento da construção da usina

\footnotetext{
${ }^{159}$ As negociações com os alemães e as tentativas de obter tecnologia da UR ENCO foram abordadas no capítulo anterior.

${ }^{160}$ Furnas já era responsável financeiramente pelas usinas do complexo Almirante Álvaro Alberto, em Angra e pela Nuclebrás. Com a extinção da Nuclebrás, a Diretoria Nuclear de Furnas assume as funções antes exercidas pela Nuclebrás, o que deveria facilitar a administração do sistema energético brasileiro, porquanto uniria, em uma mesma instituição, o controle de usinas de fontes distintas.
} 
de Angra III ${ }^{161}$, apesar da garantia de continuidade dos projetos de Angra I, inaugurada em dezembro de 1984 com elevados custos monetários ${ }^{162}$, e de Angra II ${ }^{163}$.

Apesar da ampliação do número de atores com poder de influência efetivo sobre as políticas públicas desenvolvidas pelo Executivo nacional, no caso da Energia nuclear, verificou-se à ascensão de grupos restritos em meio às agências federais responsáveis pela definição da política nuclear. Esses grupos, que ocuparam as chefias da CNEN e dos programas nucleares das três Forças Armadas, também ajudam a explicar as decisões tomadas no campo econômico, relativos à reorganização do setor nuclear no Brasil. Essa reorganização teve como principal fator a criação, no Brasil, do programa nuclear autônomo, o qual, conquanto sigiloso, passou a ditar o tom da política de cooperação nuclear nacional, afastando-a da cooperação com o Eixo Assimétrico e aproximando-a do Eixo Sul e do Eixo Regional.

Esses novos rumos da política nuclear brasileira mantiveram-se no governo Sarney, o qual se caracterizou pela manutenção daqueles grupos específicos na condução da política nuclear brasileira ${ }^{164}$, pela manutenção do programa autônomo sigiloso e pela intensificação do tom da política externa. Esta, em especial, começou a sofrer modificações no seu teor à medida que Sarney fazia uso da redemocratização como credencial para tornar as posições brasileiras no exterior mais reivindicatórias, porém

\footnotetext{
${ }^{161}$ CIA, 21 out. 1984 ; CIA, 8 set. 1986

${ }^{162}$ A usina de Angra I, segundo reportagem do Jornal do Brasil (19 jan. 1985, p. 18) teve seu custo total em 1 bilhão 800 milhões de dólares e o custo por quilowatt em 2 mil 800 dólares, o que seria três vezes superior à usina hidrelétrica de Itumbiara, na época, a maior do sistema Furnas, com custo "avaliado em 730 milhões de dólares (370 dólares por quilowatt instalado)". O Ministro de Minas e Energia do governo Figueiredo, César Cals, justificou esse valor elevado "ao pioneirismo da obra".

${ }^{163}$ Essa continuidade deveu-se à consideração do governo Figueiredo de que mais valia manter um acordo que se mostrava pouco promissor (o Acordo Brasil-Alemanha de 1975), do denunciar o acordo e, dessa forma, arriscar responsabilização internacional do Brasil e concomitante perda de mercado consumidor na Europa. Dessa forma, garantiu o presidente, ainda antes de assumir, que o princípio do pacta sunt servanda seria respeitado (A, 5 mar. 1978). A manutenção dos acordos com os alemães também foi confirmada durante as negociações para a redemocratização, na medida em que "O president da CESP, que admite ser um dos nomes cogitados para o Ministério de Minas e Energia, no Governo de Tancredo Neves, confirmou que a pretensão do novo Governo será a preservação do acordo nuclear com os alemães, argumentando que foi um acordo aprovado pelo Senado" (JORNAL DO BRASIL, 19 jan. 1985, p. 16).

${ }^{164}$ Uma análise mais retida sobre os principais atores que definiram os rumos da política nuclear brasileira poderá ser encontrada no Capítulo 1 desta dissertação. Durante os governos Figueiredo e Sarney, contudo, vale destacar a ascensão de grupos como os autonomistas e os autonomistas belicistas, nas Forças Armadas e nas agências especializadas no campo nuclear, como a CNEN. O Itamaraty, na década de 1980, possuiu relevância menor na definição da política nuclear brasileira do que aquela por ele detida no período anterior, ao passo que a Presidência da República também teve sua relevância reduzida, em especial no governo Sarney, devido às negociações para a transferência do poder aos civis, as quais incluíram a aceitação de Tancredo Neves de que os militares teriam autonomia e independência na condução da política nuclear brasileira (HUNTER, 1997; CIA, 8 set. 1986).
} 
ainda coerentes com o universalismo perseguido pela diplomacia nacional desde o governo Geisel.

Se Sarney fora limitado na sua política doméstica, o que, destaca-se aqui, incluiu a gestão da política nuclear e energética, aquela sob o controle dos grupos autonomistas ${ }^{165}$ e caracterizada pelo sigilo do programa nuclear paralelo, na política externa "tinha o mandatário liberdade para atuar de forma significativamente mais desimpedida" (CÔRTES, 2010: 56). Para manter essa atuação, o Presidente fez uso das linhas gerais da política externa brasileira, consubstanciadas pela atuação do Itamaraty, e pela manutenção das "linhas básicas de uma política externa inspirada pelo nacionalismo de fins", princípio que teria conduzido a política externa brasileira desde o Império, mas que será progressivamente abandonado na década de 1990 (LAFER, 2004:104).

Nesse sentido, duas mudanças fizeram-se presentes no governo Sarney, uma interna e outra externa. No âmbito externo, de um lado, verificou-se a conformação de postura mais incisiva contra a proliferação de armas nucleares, a qual, agora, adquiriu novo conteúdo, se comparada com os governos anteriores, na medida em que Sarney passou a relacionar a corrida armamentista global com o aumento da pobreza e da forme em âmbito internacional ${ }^{166}$. Além disso, Sarney fez uso das novas credenciais democráticas do Brasil para dar prosseguimento à estratégia de diversificação das parcerias brasileiras com os países emergentes (CORTES, 2010; VIZENTINI, 1998), processo esse que incluiu a cooperação nuclear com o Eixo Sul, relevante a partir do governo Figueiredo, a aproximação com a Argentina.

Para Sarney, assim com para Figueiredo, a dominação de tecnologia era crucial para o desenvolvimento econômico e social dos países emergentes ${ }^{167}$, e deveria ser obtida não importassem os meios. Nesse sentido, devido à crescente desilusão com o Eixo Assimétrico, o governo brasileiro, tanto sob Figueiredo quanto sob Sarney, passaria a buscar novos meios para o desenvolvimento de tecnologia nuclear, a exemplo do

\footnotetext{
${ }^{165}$ Conforme destacou Guillermo O’Donnell (1988: 281), o processo de redemocratização no Brasil foi diferente daquele dos países vizinhos na América Latina, porquanto os militares brasileiros participaram, ativamente, do processo de transição política e de detiveram, nesse processo, maior poder de ingerência nos assuntos do novo governo.

${ }^{166}$ Segundo o Sarney, a "desnuclearização da América Latina deve ser o primeiro passo de um novo impulso para deter a acumulação vertical e horizontal das armas nucleares, liberando-se o milhão e meio de dólares desperdiçados cada minuto pela corrida armamentista para o combate à fome, à doença, à ignorância e à miséria." (SARNEY, 23 set. 1985).

167 "Povos que dominam tecnologias e povos que esgotam suas aspirações apenas na alimentação. A América Latina não pode ficar condenada ao pauperismo. Para impedir que isso possa acontecer é que nós, políticos do presente, temos que construir as barreiras do futuro. Não poderemos fazer isso sós, cada um, isolado. Venceremos o tempo e a guerra. Vamos juntar nossos esforços, nossos cérebros, integrar nossas experiências e livrar-nos de todas as dependências. Crescer juntos." (SARNEY, 29 Jul. 1986)
} 
programa paralelo e da parceria com países poucos tradicionais no rol das parcerias internacionais do Brasil, como o Iraque e a China, os quais serão posteriormente tratados.

No âmbito doméstico, o governo Sarney, diferentemente de seu antecessor, caracterizou-se pela impotência no campo da definição de política nuclear, pois essa fora controlada, em um primeiro momento, pelos grupos autonomistas, como parte do acordo de abertura firmado com o presidente Tancredo Neves, e, em um segundo momento, a partir de 1986 (HUNTER, 1997), pela maior atuação da Assembleia Constituinte (1986-1988). Esse segundo momento, conquanto não tenha gerado mudanças imediatas na política nuclear de Sarney, em parte devido ao pouco interesse do presidente no assunto ${ }^{168}$, foi de extrema relevância para a porvindoura mudança de rumos da política atômica brasileira no governo Collor, bem como para a implementação de cooperação estratégica em meio ao Eixo Regional.

Essa relevância decorreu das discussões sobre a definição dos dispositivos constitucionais que definiriam os rumos da política nuclear brasileira, as quais levaram ao artigo 21, XXIII, da CF/88 ${ }^{169}$. Esse artigo fora fruto do embate entre o lobby político dos grupos autonomistas, presentes no governo desde a administração Figueiredo, e dos grupos contrários à política autonomista na esfera nuclear - tanto aqueles ainda favoráveis à cooperação com o Norte Global quanto aqueles emergentes na sociedade civil após o acidente de Chernobyl (25 de abril de 1986), contrários ao uso da fissão nuclear para fins energéticos ${ }^{170}$. Importante destacar a conflagração entre essas duas diferentes perspectivas ante os constituintes levou à definição de texto constitucional abrangente, cuja interpretação permitisse aos militares continuar a "desenvolver explosivos nucleares pacíficos ou de enriquecer urânio fora das salvaguardas internacionais", e não estabeleceram mecanismos para implementar a supervisão civil" (BARLETTA, 1997: 19, tradução livre). De fato, as explosões nucleares pacíficas, como se verá a seguir, serão ponto fundamental da justificativa do programa nuclear autônomo, assim como do discurso externo brasileiro no campo atômico.

\footnotetext{
${ }^{168}$ CIA, 8 set. 1986

${ }^{169}$ Cabe à União (...) XXIII - explorar os serviços e instalações nucleares de qualquer natureza e exercer monopólio estatal sobre a pesquisa, a lavra, o enriquecimento e reprocessamento, a industrialização e o comércio de minérios nucleares e seus derivados, atendidos os seguintes princípios e condições: a) toda atividade nuclear em território nacional somente será admitida para fins pacíficos e mediante aprovação do Congresso Nacional;

${ }^{170}$ Uma melhor categorização sobre esses grupos pode ser encontrada no capítulo 1 desta dissertação.
} 


\section{O Programa Nuclear Autônomo}

Formulado ainda ao final do governo Geisel, porém implementado por João Figueiredo, o programa nuclear autônomo constituiu a base para o esforço dos grupos autonomistas de obtenção de energia nuclear de autóctone. O programa nuclear paralelo, ou autônomo, segundo nomenclatura oficial, era composto de quatro projetos independentes desenvolvidos pelas três forças armadas, os quais constituíram projeto difuso e pouco coordenado (BARLETTA, 1997: 6; PATTI, 2014b).

Esse controverso programa desenvolveu-se ao largo do regime internacional de não proliferação nuclear (PATTI, 2014b), de modo a possuir, portanto, menos restrições do que aquelas que pautavam o programa oficial, gerido pela Nuclebrás e por Furnas, e que foram instituídas pelos acordos firmados com a República Federal da Alemanha e com a AIEA entre 1974 e 1976. Essa maior liberdade de atuação permitiu o desenvolvimento, pela CNEN e pelas Forças Armadas, de tecnologia de uso dual (PATTI, 2014b), como o enriquecimento de urânio por ultra-centrifugação de levitação magnética, a qual constitui tecnologia exclusivamente brasileira.

Foram amplas as justificativas que teriam induzido o governo brasileiro a desenvolver um programa nuclear autônomo, de caráter sigiloso. A desilusão com o Eixo Assimétrico, em especial após o fracasso do uso comercial do jato centrífugo, e a continua necessidade de manter a expansão da capacidade energética brasileira podem, contudo, ser consideradas as principais justificativas para a constituição de programa o qual, acreditavam os autonomistas, seria o meio mais eficaz para garantir a autosuficiência do Brasil no campo nuclear ${ }^{171}$. Buscava-se, em suma, obter tecnologia nuclear com "esforço exclusivamente brasileiro e com investimentos relativamente baixos", conforme concluído pela CPMI sobre o programa nuclear paralelo (CN, 1990, p. 106). Além disso, outro objetivo a ser adquirido com a obtenção de tecnologia nuclear foi a busca de prestígio global, advindo da maior capacidade tecnológica do país ${ }^{172}$.

O programa nuclear autônomo ter-se-ia iniciado como um projeto relativamente independente dentro do programa nuclear brasileiro. Essa independência tinha dois objetivos. De um lado, a permanência do projeto, inicialmente, no mesmo sistema do programa nuclear mais abrangente deveria facilitar a obtenção de financiamento ${ }^{173}$,

\footnotetext{
${ }^{171} \mathrm{CN}, 1990$

${ }^{172}$ CIA, 21 out. 1983.

${ }^{173}$ CN, 1990, p. 44.
} 
oriundos dos recursos cedidos pelo Executivo aos órgãos responsáveis pela condução da política atômica, em especial a CNEN. Por outro lado, o afastamento dos demais projetos desenvolvidos pelo Brasil era considerado, pelos grupos autonomistas que conduziram o projeto, característica fundamental para o êxito do programa autônomo. Isso ocorria porque os demais projetos, advindos de acordos de cooperação com os Estados Unidos (Angra I) e com a Alemanha Federal (Angra II), estavam submetidos a tratados de salvaguardas internacionais que previam amplo acesso, por exemplo, da AIEA e de inspetores de Bonn às instalações de pesquisa e às usinas comerciais brasileiras. De fato, como lembrou o general Danilo Venturini, em depoimento realizado à CPMI sobre o programa nuclear paralelo $(\mathrm{CN}, 1990$, p. 45), o afastamento com relação aos demais projetos do programa nuclear brasileiro era necessário "porque senão estaríamos infringindo acordos internacionais", o que constituía preocupação precípua do Ministro das Relações Exteriores brasileiro, Ramiro Saraiva Guerreiro.

É relevante ressaltar, também, que o projeto autônomo teria objetivo exclusivamente de pesquisa, ou seja, não comercial ${ }^{174}$. Isso garantiria a sua não inclusão no arcabouço institucional acordado com os países do Eixo Assimétrico , bem como permitiria maior maleabilidade orçamentária. Isso ocorreria porque os acordos firmados pelo Brasil com Bonn não previam o acesso alemão no Brasil a quaisquer tecnologias atômicas que não aquelas oriundas do jato centrífugo, da mesma forma como proibia, a Alemanha de disponibilizar unilateralmente ao Brasil tecnologia da URENCO. Criou-se, dessa forma, uma janela jurídica para que os grupos autonomistas, liderados pela CNEN, desenvolvessem o projeto do programa paralelo, porquanto ao Brasil seria permitido desenvolver quaisquer tecnologias nucleares autonomamente, desde que distintas do jato centrífugo, cuja viabilidade já era questionada pelos cientistas brasileiros.

Dessa forma, como maneira de facilitar os trabalhos de pesquisa, os grupos envolvidos no desenvolvimento do programa paralelo optaram por conduzi-lo de modo sigiloso. Esse sigilo fazia-se necessário, afirmavam os grupos formuladores do programa paralelo, em especial na CNEN e nas Forças Armadas, de modo a evitar pressão internacional contrária ao desenvolvimento autóctone de tecnologia nuclear pelo Brasil ${ }^{175}$. Isso significava afastar a Nuclebrás de exercer qualquer poder de ingerência nos rumos do programa nuclear ${ }^{176}$ e conferir à CNEN e às Forças Armadas

\footnotetext{
${ }^{174}$ CN, 1990, p. 9

175 Depoimento do general Danilo Venturini à CPMI sobre o programa nuclear paralelo (CN, 1990, p. 44)

${ }^{176}$ CARVALHO, 13 nov. 1984
} 
autonomia administrativa para gerir o programa paralelo, com recursos destinados ao programa nuclear, entendido de forma abrangente. Esse processo teria levado ao fortalecimento institucional da CNEN e ao progressivo enfraquecimento da Nuclebrás, a qual será, inclusive, extinta em 1989, após a confirmação por Sarney da decisão de Figueiredo de adiar, de modo indefinido, a construção de Angra III.

O sigilo também era necessário para permitir a condução das pesquisas sobre tecnologia nuclear fora de eventuais pressões internacionais. Nesse sentido, fazia-se comparação com o Projeto Manhattan ${ }^{177}$, cujo caráter sigiloso teria facilitado aos americanos desenvolver a bomba atômica, pois teria evitado a repercussão negativa do projeto em meio à opinião pública (VARGAS, 1997). Dessa forma, o sigilo far-se-ia relevante, pois se acreditava que a população poderia, no caso brasileiro, mostrar-se contrária à utilização de recursos públicos para obter tecnologia nuclear de possível uso dual $^{178}$. Essa consideração é relevante, na medida em que o Brasil, nos governos Figueiredo e Sarney, se redemocratizava e, dessa forma, a administração federal passava a ser cada vez mais sensível a pressões populares. A própria CMPI de 1990 concluiu que o distanciamento da opinião pública, oriundo do empoderamento da CNEN e das Forças Armadas, seria aspecto negativo do programa paralelo ${ }^{179}$.

Vale ainda salientar duas perspectivas distintas quanto à necessidade de sigilo para 0 programa paralelo, observadas em meio às discussões na CMPI de 1990. A primeira perspectiva é aquela oficial, advinda de atores partícipes da condução do programa autônomo, como o almirante Othon Luiz Pinheiro, segundo o qual o sigilo era necessário para evitar pressões externas; a segunda perspectiva, conferida pelo Secretário da Ciência e Tecnologia do governo Collor, José Goldemberg, era que o sigilo se fazia necessário, apenas, para garantir verbas fáceis e a não fiscalização pelos demais órgãos do governo. Acredita-se que ambas as perspectivas tenha fundamento, apesar de o orçamento para o programa autônomo, como um todo, ter sido consideravelmente escasso $^{180}$, devido à crise econômica pela qual passava o país.

Outra consequência da clandestinidade do programa teria sido o prosseguimento de pesquisas realizadas por uma parcela do grupo dos autonomistas, em especial ligada à Aeronáutica, com o objetivo de desenvolver armas nucleares. Esses grupos são aqueles

\footnotetext{
${ }^{177}$ Depoimento do general Danilo Venturini à CPMI de 1990 (p. 44).

178 Depoimento do almirante Maximiano à CPMPI de 1990 (p. 106).

${ }^{179}$ Como afirmado pela comissão, “a centralização dos poderes de formular política, licenciar obras e fiscalizá-las, como ocorreu com a CNEN, não foi a melhor opção” (CN, 1990, p. 106).

${ }^{180}$ CN, 1990; CIA, 21 out. 1983; CSN, 21 fev. 1985
} 
que aqui se denomina de belicistas e que foram analisados no Capítulo 1, os quais entendiam como necessária a busca brasileira de tecnologia nuclear para usos múltiplos, como uma possível bomba. Para esses grupos, como afirmado por membros das forças armadas a Paulo Nogueira Batista ${ }^{181}$, a possibilidade de obter tecnologia atômica para construir possível artefato nuclear era vista, por esses grupos, como uma possível necessidade brasileira para manter a autonomia ante a possíveis ameaças externas ${ }^{182}$, como o teria ocorrido com a França, na crise de Suez ${ }^{183}$. Além disso, assim como a França, na análise dos militares brasileiros, teria optado em definitivo pela opção nuclear após ter sido enxertada de Suez pela ação diplomática conjunta das duas superpotências, a derrota argentina na Guerra das Malvinas (abril- junho de 1982) também poderia levar Buenos Aires a seguir pelo mesmo caminho. Dessa forma, o Brasil, ao não possuir armamentos atômicos, poderia encontrar-se em situação de vulnerabilidade.

Cabe lembrar que a obtenção de armamentos nucleares não feria, na perspectiva brasileira, os acordos internacionais aos quais o país estava submetido. De fato, a não adesão ao TNP e as ressalvas feitas na assinatura do Tratado de Tlatelolco abriram margem para a consolidação, no repertório da política externa brasileira, da tese das explosões pacíficas (REDRIK, 1975). Essa tese foi progressivamente defendida pela diplomacia pátria nas décadas de 1960 e de 1970, tanto de maneira independente quanto em cooperação com outros países do Sul Global proponentes dessa mesma perspectiva $^{184}$. Embora a tese das explosões pacíficas tenham se enfraqulecido, a ponto de quase esmaecer, após os testes nucleares da Índia ${ }^{185}$, outrora grande propugnadora dessa perspectiva, em 1974, ela continuou a definir o tom da política nuclear brasileira o exterior até o governo Collor.

As explosões pacíficas foram tese inicialmente levantada pelos próprios Estados Unidos e defendida, entre outros, pelo presidente americano Lyndon Johnson ${ }^{186}$, e Richard Nixon, o qual, inclusive, afirmou a necessidade de se desenvolverem acordos

\footnotetext{
${ }^{181}$ BATISTA, 05 ago. 1982

182 BATISTA, 06 nov. 1975

${ }^{183}$ Essa crise deveu-se à declaração de guerra por Israel, com apoio da França e da Inglaterra, contra o Egito, em 1956, devido à nacionalização do canal de Suez pelo presidente Gamal Abdel Nasser.

${ }^{184}$ DEUTSCHER BUNDESTAG, 12 dez. 2007

${ }^{185}$ DEUTSCHER BUNDESTAG, 12 dez. 2007

${ }^{186}$ JOHNSON, 14 fev. 1968
} 
internacionais específicos para regular esse tipo de explosão ${ }^{187}$. A maior repercussão da tese foi, porém, entre os países do Sul Global, que relacionaram as restrições à obtenção de tecnologia nuclear de uso dual com a tentativa de manter hierarquização injusta do sistema internacional (VARGAS, 2009). A tese afirmava que, para ser considerado arma nuclear, "um explosivo deve ser destinado a fins militares" (REDRICK, 1975: 24, tradução livre), embora, tenham admitido diplomatas brasileiros, a tecnologia para fins militares e aquela para fins pacíficos fosse idêntica.

A utilização de explosivos para fins pacíficos, por exemplo, na construção civil, era considerada pelo Brasil, bem como pela Argentina, parte essencial de suas respectivas políticas externas para o campo nuclear e foi abarcada, de forma implícita, pelo Tratado de Tlatelolco no artigo $17^{188}$, o qual autoriza, segundo o entendimento clássico dos países latino-americanos e as ressalvas $^{189}$ de interpretação feitas pela delegação brasileira $^{190}$, as explosões nucleares para fins pacíficos (GROSS ESPIELL, 1973: 134). Esse entendimento foi cabal para o adiamento, pelo Brasil, da entrada em pleno vigor do tratado naquele país, pois, segundo reserva feita no momento da assinatura, a ratificação dependeria da adesão no tratado de todos os países nuclearmente armados no globo (GROS ESPIELL, 1973), o que não se tornava possível na medida em que a União Soviética não aceitava a tese das explosões pacíficas ${ }^{191}$.

A tese das explosões pacíficas também teve considerável repercussão no ambiente político interno brasileiro, em especial na Assembleia Constituinte, quando se definiu na Constituição Federal o dispositivo relativo aos usos pacíficos da energia nuclear (artigo 21, XXIII, a)) com termos semelhantes àqueles previstos no Tratado de Tlatelolco. Isso significa que, em tese, estaria permitido ao Brasil desenvolver explosivos nucleares, desde que para fins pacíficos (BARLETTA, 1997). Essa dubiedade da constituição decorreu, como lembra Barletta (1997) e Hunter (1997), do lobby de grupos ligados aos

\footnotetext{
187 "The statement [of the Additional Protocol II to the NPT] also reaffirms our willingness to make available nuclear explosion services for peaceful purposes on a nondiscriminatory basis under appropriate international arrangements." (NIXON, 13 aug. 1970).

188 "Ninguna de las disposiciones contenidas en el presente Tratado menoscaba los derechos de las Partes Contratantes para usar, en conformidad con este instrumento, la energía nuclear con fines pacíficos, de modo particular en su desarrollo económico y progreso social."

${ }^{189}$ MRE, 26 mar. 1974

${ }^{190}$ Em telegrama enviado ao chanceler de Geisel, Azeredo da Silveira (OPANAL, 29 mar. 1977), pelo Secretário Geral da OPANAL, o texto do Tratado de Tlatelolco, a OPANAL deveria garantir a seus países membros utilizar a energia nuclear para fins pacíficos em suas mais diversas formas, o que gerava divergências de opiniões entre grupos liderados pelo Brasil, que entendia incluir esse dispositivos explosões pacíficas, e grupos liderados pelo México, que afirmavam inexistirem esse tipo de explosão, porquanto a tecnologia para os supostos "explosivos pacíficos" e os militares era a mesma.

${ }^{191}$ OPANAL, 29 mar. 1977)
} 
militares autonomistas ${ }^{192}$ na Assembleia Constituinte ${ }^{193}$. Apenas no governo Collor o governo abandonará a clássica defesa das explosões pacíficas e adotará a posição até hoje defendida pelo Brasil, segundo a qual todo artefato explosivo nuclear é arma militar, portanto não poderá ser obtida.

Sigilo e sutilezas jurídicas políticas marcaram a trajetória do programa nuclear paralelo, o qual teve sua própria estrutura organizacional alterada durante sua vigência. Embora o programa paralelo tenha-se iniciado como projeto independente dentro do programa nuclear brasileiro, no decorrer de sua consecução ele adquiriu proporções relativamente grandes e distanciou-se, crescentemente, do programa oficial a cargo da Nuclebrás e da Furnas. Esse distanciamento deveu-se tanto à supra-referida necessidade de sigilo quanto devido à própria estrutura do programa, a qual contribuiu para dificultar o acesso dos órgãos federais e legislativos de fiscalização e de accountability.

Conquanto, inicialmente, o programa tenha-se conformado, de modo limitado, a projetos de pesquisa em tecnologia nuclear semelhante àquela da URENCO $^{194} \mathrm{em}$ instituições como a CNEN e o IPEN ${ }^{195}$, ele logo se expandiu para outros ramos da máquina estatal (PATTI, 2013b). Conformou-se, então, ampla e difusa estrutura, afastada, na prática, do programa oficial, a qual foi gerida pelas três forças armadas e pela $\mathrm{CNEN}$, sob supervisão do $\mathrm{CSN}^{196}$. Apesar de serem quatro os principais projetos que integravam o programa autônomo, o projeto contava com um conjunto de cinco projetos militares e sete civis coordenados pela CNEN, como ilustrado pelo Quadro 6, e com pouco diálogo entre seus partícipes. Em especial aos quatro projetos militares, a CNEN teria cedido o corpo técnico necessário para sua implementação; ressalva-se,

\footnotetext{
${ }^{192}$ Exemplo da disputa travada entre grupos políticos rivais sobre a definição do artigo 21 da Constituição pode ser visto no debate, ocorrido na CPMI de 1990 sobre o programa nuclear paralelo, entre o então deputado José Genoíno e o almirante Othon Luiz Pinheiro. Genoíno afirmou ter sido derrotado, com seu grupo, na Constituinte, pois na CF/88 apareceu a expressão "fins pacíficos", e não "fins militares", ao passo que Othon Pinheiro disse: "v. Exa. não foi derrotado e o Brasil ganhou com aquela decisão na Constituinte. V. Exa. Não foi derrotado porque se fosse aprovado o texto proibindo aplicações militares e déssemos cumprimento ao texto, um radioisótopo não poderia ser aplicado num soldado, porque o soldado tem fins militares. Entendo o problema do legislador. Veja o que ocorreu com os argentinos, na guerra das Malvinas. O Governo protestou porque os ingleses colocaram, numa zona desnuclearizada, um submarino nuclear. A Agência Internacional de Energia Atômica, num parecer disse: a propulsão nuclear não é uma arma, apenas substitui um outro processo de propulsão. Então, estamos no mesmo dilema" (CN 1990: 73).

${ }^{193}$ Depoimento de José Luiz de Santana Carvalho à CPMI do programa nuclear paralelo (CN, 1990: 86)

${ }^{194}$ Sobre as relações entre o programa nuclear autônomo e a tecnologia da URENCO, vale lembrar, conforme destaca Luiz Alberto Moniz Bandeira (2013:197), citando a repórter Tânia Malheiros, que fugiu para o Brasil o antigo diretor da subsidiária da URENCO, Machinenfabrik Augsburg-Nuernberg, KarlHeinz. Ele teria trabalhado no desenvolvimento do programa de construção de tecnologia centrífugas na base da Aramar e junto à IPEN.

${ }^{195}$ CSN, 21 fev. 1985

${ }^{196}$ CSN, 21 fev. 1985
} 
porém, o aspecto diferenciado do Projeto Solimões, o qual foi alcunhado pelo antigo presidente da CNEN durante o governo Collor. José Luiz de Santana Carvalho, em entrevista concedida ao autor em 16 de fevereiro de 2016, de "o programa paralelo do paralelo".

Quadro 6 - A estrutura do programa nuclear autônomo

\begin{tabular}{|c|c|c|c|}
\hline Projeto Ciclone & Ministério da Marinha & $\begin{array}{l}\text { - Desenvolvimento de método de ultra- } \\
\text { centrifugação para enriquecimento de urânio; } \\
\text { - Construção de Planta de Demonstração; }\end{array}$ & Aramar (SP) \\
\hline Projeto Remo & Ministério da Marinha & $\begin{array}{l}\text { Desenvolvimento de reatores nucleares para } \\
\text { propulsão de submarinos e navios; }\end{array}$ & Aramar (SP) \\
\hline Projeto Atlântico & Ministério do Exército & $\begin{array}{l}\text { - Desenvolvimento de tecnologia de produção de } \\
\text { grafite nuclearmente puro, para a fabricação de } \\
\text { moderadores para reatores a urânio natural; } \\
\text { - Construção de reator de pequeno porte, com } \\
\text { urânio natural e grafite, com capacidade de } \\
\text { produção de plutônio. }\end{array}$ & Guaratiba (RJ) \\
\hline Projeto Solimões & Ministério da Aeronáutica & $\begin{array}{l}\text { - Desenvolvimento de tecnologia de laser para } \\
\text { objetivos civis e militares; } \\
\text { - Desenvolvimento de explosivos para fins } \\
\text { pacíficos; }\end{array}$ & $\begin{array}{l}\text { Centro técnico } \\
\text { Aeroespacial, em São José } \\
\text { dos Campos (SP); Base do } \\
\text { Cachimbo (PA); }\end{array}$ \\
\hline $\begin{array}{l}\text { Projeto Conversão } \\
\text { (PROCON) }\end{array}$ & CNEN / IPEN & $\begin{array}{l}\text { - Produção de compostos de urânio (natural e } \\
\text { enriquecido) necessários aos demais projetos; }\end{array}$ & São Paulo (SP) \\
\hline Projeto Celeste & CNEN / IPEN & $\begin{array}{l}\text { - Reprocessamento de combustível para produção } \\
\text { de plutônio }\end{array}$ & $\begin{array}{l}\text { São Paulo (SP), Rio de } \\
\text { Janeiro (RJ) }\end{array}$ \\
\hline Metalurgia & CNEN & $\begin{array}{l}\text { - Preparação de urânio metálico e domínio da } \\
\text { tecnologia necessária às suas aplicações }\end{array}$ & 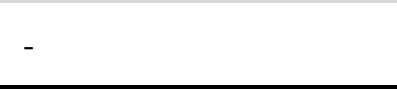 \\
\hline
\end{tabular}

Fontes: CN, 1990; CSN, 21 fev. 1985; BARLETTA, 1997; SILVA, MARQUES, 2006; DURAZZO, sem data. Elaboração própria.

Das três forças armadas, a Marinha constituiu-se aquela que dispensou mais tempo, recursos e pessoal ${ }^{197}$ no desenvolvimento autônomo de tecnologia nuclear, bem como foi aquela cujos projetos mostraram-se mais exitosos. Isso ocorreu por estar a Marinha, desde as tratativas do almirante Álvaro Alberto na década de 1950 (SATO, 2013), envolvida na busca de obter tecnologia nuclear própria, em especial para a propulsão de submarinos nucleares ${ }^{198}$. Esse tipo de submarino, objetivo do chamado Projeto Remo, é considerado, pelo almirantado, crucial para a proteção do mar territorial e da Zona Econômica Exclusiva brasileiros e para evitar vulnerabilidades externas (CN, 1990: 55-

\footnotetext{
${ }^{197}$ Em 1990, a CNEN havia cedido à Marinha por volta de 200 técnicos para o desenvolvimento de tecnologia nuclear própria (CN, 1990: 81), muitos dos quais partícipes de cursos de pós-graduação em áreas afeitas à tecnologia nuclear em países como a Alemanha (parte do Acordo de 1975).

${ }^{198} \mathrm{O}$ projeto de construção de submarino movido a propulsão nuclear pelo Brasil ainda não obteve êxito e segue em operação, atualmente em cooperação com a França.
} 
56). A posse de submarino nuclear também era, e continua a ser, considerada vital para a defesa da soberania nacional em caso de conflito externo com outras potências. Isso ficou claro para a Marinha após a Guerra das Malvinas, na qual a derrota argentina fora creditada, entre outros fatores, à presença de submarino nuclear inglês no arquipélago ${ }^{199}$ (KASSENOVA, 2014). Além disso, argumentava o almirantado da Marinha, que os reatores produzidos para os submarinos poderiam ser convertidos em "equipamento de exportação e em usinas energéticas de menor porte ${ }^{200 "}$ (CN, 1990: 59).

$\mathrm{Na}$ base de Aramar, em Iperó, São Paulo, a Marinha brasileira coordenou dois projetos: o Projeto Ciclone, que objetivava desenvolver método de ultra-centrifugação para enriquecimento de urânio; o Projeto Remo, que objetivava desenvolver pequenos reatores nuclear para propulsão de submarinos ou de navios de pequeno porte. Enquanto este ainda encontra-se em execução, porém sob nova roupagem e de maneira mais transparente, aquele foi, efetivamente, desmantelado e incorporado ao programa oficial na década de 1990. Vale salientar que o Projeto Ciclone foi exitoso em dar ao Brasil tecnologia própria para ultra-centrifugação de urânio (SILVA; MARQUES, 2006), bem como dar ao Brasil condições para o desenvolvimento posterior de enriquecimento de urânio por ultra-centrifugação magnética.

O Exército, por sua vez, coordenou o Projeto Atlântico, que tinha como objetivo desenvolver reatores movidos a urânio natural, presente em larga medida no país, e a grafite. Essas tecnologias, desenvolvidas, de modo pouco exitoso, no Centro de Tecnologia do Exército, em Guaratiba, Rio de Janeiro, eram semelhantes àquelas desenvolvidas, desde a década de 1960, pelo programa nuclear autônomo argentino, conduzido pela CEA e criticado, anteriormente, pela administração Geisel ${ }^{201}$. O ponto mais polêmico do projeto do Exército, que, inclusive, teria conduzido a suspeitas de desenvolvimento de armamentos nucleares, é o fato de a tecnologia de geração de energia por urânio natural levar à formação de consideráveis quantidades de plutônio, o qual constitui matéria prima para bombas atômicas como a indiana. A esses temores, a

\footnotetext{
${ }^{199}$ Vale ressalvar a memória presente nas Forças Armadas da questão da ilha de Trindade, ocupada pelos ingleses entre 1890 e 1896, em acordo obtido com a mediação portuguesa.

${ }^{200}$ Vale salientar que o projeto de construção de usinas nucleares de pequeno porte foi, recentemente, reavivado pelo governo Dilma Rousseff, em parceria com a sua então homóloga argentina Cristina Kirchner (OLIVEIRA, 2007).

${ }^{201}$ Em telegrama enviado por Azeredo da Silveira ao presidente Geisel, o chanceler afirma que o programa argentino era baseado na tecnologia de produção energética por uranio natural, que não era técnica confiável, porque "foi abandonada" por países com know how "mais avançado, como GrãBretanha e a França, e a Índia, que também tinha optado por via mais nacionalista, desistiu dessa via e aderiu a usinas de urânio enriquecido" (MRE,04 abril 1974:6).
} 
SAE respondeu, em $1990^{202}$, que o reator perseguido pelo exército era para "fins exclusivamente energéticos e que plutônio é produzido, em maior ou menor escala, por 'todos os reatores"'. Apesar dessas justificativas, vale lembrar que documento enviado pela CSN ao presidente Sarney sobre a estrutura do programa paralelo ${ }^{203}$ apresentava como um dos objetivos explícitos desse projeto a "construção de reator de pequeno porte, com urânio natural e grafita, com capacidade de produção de plutônio" (destaque nosso). O Projeto Atlântico não foi continuado na década de 1990 e seus equipamentos foram cedidos a universidades públicas federais (FOLHA, 6 maio 1997).

A Aeronáutica desenvolvia o Projeto Solimões, o qual comportava aquele de teor mais polêmico, porquanto pesquisava tecnologia de laser para objetivos nuclear e convencionais, bem como o desenvolvimento de explosivos nucleares para fins pacíficos (BARLETTA, 1997: 6). Dessa forma, era o projeto da Aeronáutica aquele que mais se relacionava à tese das explosões pacíficas, bem como aquele que teria instado seus membros a evitarem mudança da perspectiva brasileira nesse campo, por exemplo, por meio de lobby na Assembleia Constituinte. O projeto fora desenvolvido em múltiplas localidades, porém com sede principal no Centro Técnico Aeroespacial, em São José dos Campos, São Paulo, e com possível campo de testes para explosivos nucleares na Serra do Cachimbo ${ }^{204}$, no Pará (SPEKTOR, 2015).

O Projeto Solimões foi aquele que mais demandou sigilo por parte de seus partícipes, pois seria o alvo mais propício de possíveis pressões estrangeiras e domésticas a ele contrárias. De fato, a questão do sigilo chegou a ponto de, em depoimento feito à CPMI sobre o programa autônomo, o presidente da CNEN durante o governo Collor, José Luiz de Santana Carvalho, ter afirmado desconhecer o projeto Solimões - apesar de ele ter estado vinculado, segundo organograma exposto ao presidente Sarney $^{205}$, à CNEN. O projeto também não teria sido constado no quadro

\footnotetext{
${ }^{202} \mathrm{CN}, 1990: 102$.

${ }^{203}$ CSN, 21 fev. 1985.

204 Apesar de ser considerada possível campo de testes nucleares, a área de Serra do Cachimbo apresentava, segundo reportagem da Folha de São Paulo (08 aug. 1986), algumas falhas geológicas que poderiam impedir o êxito de possíveis testes de explosivos nucleares, como, por exemplo, a presença de água e a formação por rocha sedimentária, como calcário, arginina e arenito. Essas características impossibilitariam o armazenamento de material radioativo no local, além do que os mananciais de água seriam imediatamente contaminados com a radiação, o que geraria consequências graves para a população local. Vale recordar, nesse sentido, que testes nucleares anteriores realizados por outros países, normalmente, em locais isolados e com pouca possibilidade de contaminação, como no caso do Deserto Jornada del Muerto, no caso dos Estados Unidos, ou no atol de Bikini, no caso da França.

${ }^{205}$ CSN, 21 fev, 1985
} 
institucional $^{206}$ da $\mathrm{SAE}^{207}$. Talvez esse excessivo sigilo, devido ao desenvolvimento de tecnologia para explosões pacíficas (VARGAS, 1997), tenha suscitado o presidente Collor, em decisão autônoma ${ }^{208}$, a realizar o simbólico ato de jogar uma "pá de cal" no buraco da Serra do Cachimbo designado para campo de testes.

Os demais programas, de operação por civis e geridos pela CNEN foram, logo, abarcados aos demais, inclusive porque tinham como orientação fornecer insumos para os quatro projetos principais (Remo, Ciclone, Atlântico, Solimões). Nos projetos geridos exclusivamente pela CNEN destaca-se o Projeto Celeste, que objetivava criar condições para reprocessamento de combustível para produção de plutônio ${ }^{209}$ - portanto projeto relacionado com a busca por execução futura de explosões pacíficas e, possivelmente, com o Projeto Solimões. As demais atividades desenvolvidas pela CNEN foram a preparação de urânio metálico e as tecnológicas necessárias para suas aplicações, o controle radiométrico e ambiental das instalações de todos os projetos, a fabricação de equipamentos elétricos e materiais necessários pelos três programas.

Apesar de divulgações preliminares de partes dos projetos de pesquisa desenvolvidos pelo programa paralelo em 1983 e $1984^{210}$, a existência do programa paralelo foi tornada pública em 1987, pelo presidente José Sarney, juntamente com o anúncio de que o Brasil teria conseguido desenvolver, de forma autônoma, tecnologia de ultracentrifugação própria. O programa nuclear autônomo foi desmantelado, completamente, em 1990, pelo governo Collor, juntamente com o processo de consolidação da aproximação bilateral com a Argentina (SARAIVA, 2012) transformação o Eixo Regional em Cooperação Estratégica - e com o afastamento dos países do Eixo Sul, o qual, como se verá a seguir, possuiu grande relevância no processo de viabilização do programa paralelo.

Embora a consolidação do Programa Autônomo denote a ênfase conferida pelos governos Figueiredo e Sarney à busca de desenvolvimento autóctone de tecnologia nuclear, o que seria feito de forma quase auto-suficiente, como exposto, em especial, pela função divisão de tarefas entre os ministérios das três forças armadas e a CNEN, as

\footnotetext{
${ }^{206} \mathrm{CN}, 1990$

${ }^{207}$ A SAE, Secretaria de Assuntos Estratégicos, foi a sucessora da CSN em diversos pontos, e, segundo o instrumento de sua criação, o Decreto No 99.373, de 4 de julho de 1990, Art. $1^{\circ}$, V, tinha como finalidade, entre outros pontos, "coordenar a formulação da Política Nacional Nuclear e supervisionar sua execução". A SAE tinha, dessa maneira, como um dos objetivos garantir maior transparência ao programa nuclear brasileiro.

${ }^{208}$ Entrevista de José Luiz de Santana Carvalho ao autor, 18 fev. 2016

${ }^{209}$ CSN, 21 fev. 1985

${ }^{210}$ CIA 21 out 1983; CARVALHO, 11 nov. 1984
} 
relações bilaterais continuaram a manter certa função de relevância na definição da política nuclear brasileira, como será verificado a seguir, ao analisar, especificamente, os eixos Assimétrico, Regional e Sul.

\section{Desilusão: cenário externo desfavorável, crise da dívida externa, crise energética, afastamento da Alemanha Federal}

As relações do Brasil com o Eixo Assimétrico das relações bilaterais da política nucelar podem ser caracterizadas, entre 1979 e 1989, como pouco dinâmicas, em especial se comparadas com os períodos imediatamente anterior e posterior. Nesse período, o governo brasileiro consolidou a desconfiança que já se delineava contra os países do Norte Global em fins da administração Geisel. Essa consolidação deveu-se tanto à desilusão pela qual passaram os agentes do Executivo após a não concretização de todos os objetivos previstos no Plano 90 e no conjunto de acordos de cooperação com a Alemanha Federal assinado entre 1974 e 1976 quanto à intensificação das pressões dos Estados Unidos contrárias às ambições nucleares brasileiras (VARVAS, 1997).

Logo nos últimos momentos da administração Ford, ampliavam-se, nos Estados Unidos, os alardes relativos às possíveis ambições nucleares brasileira (GALL, 1976; MONIZ BANDEIRA, 1989, 2013), ao que se somava a crescente desconfiança da Casa Branca com relação à tese das explosões pacíficas, especialmente após os testes nucleares indianos. Esses alardes ocorreram, ao menos, em âmbito discursivo, mesmo que Washington considerasse, como mostrado por estudos realizados pela CIA ${ }^{211}$, que o Brasil não detinha tecnologia que o permitisse desenvolver tecnologia nuclear dual em menos de cinco $\operatorname{anos}^{212}$, em uma avaliação otimista que desconsiderasse a situação econômica sensível do país.

A pressão americana contrária às ambições nucleares brasileiras, que já tinha, no período anterior, contribuído para a conformação da "vertente perturbadora" (LESSA, 1998) com os Estados Unidos, exacerbou-se no governo Carter ${ }^{213}$, quando o presidente transformou a não proliferação em uma das suas principais bandeiras políticas (BRENNER, 2009). Como engenheiro nuclear, Carter via na não proliferação de armas nucleares um dos seus principais objetivos na Casa Branca e, para tal, mobilizou a

${ }^{211}$ CIA, 13 jan. 1982

${ }^{212}$ CIA 21 out. 1983

${ }^{213}$ SCIENCE, 18 fev. 1977 
diplomacia de seu país no sentido de aprofundar os rumos políticos delineados pelas administrações Nixon e Ford.

Entre esses rumos, destacam-se a multilateralização do tema ${ }^{214}$, o que implicou uso do GSN para tentar criar arcabouço normativo que impossibilitasse a aquisição de tecnologia nuclear por países não adeptos ao TNP, e as pressões bilaterais contra fornecedores competidores com os Estados Unidos, como a França e a Alemanha. Essa multilaterização incluiu aumento das pressões contra países como a Alemanha Federal $^{215}$, os quais já tinham firmado acordo de cooperação com países não aderentes ao TNP, bem como se enquadrou na política de redução dos custos da hegemonia americana na gestão da ordem internacional, implementada desde a gestão Kissinger na Secretaria de Estado. A política de Carter contribuiu, ao contrário do esperado, para a intensificação dos esforços autóctones para desenvolvimento de tecnologia nuclear por países como o Brasil e África do $\mathrm{Sul}^{216}$, portanto os afastando das instituições nele vigentes no regime internacional de não proliferação nuclear, como o TNP e o sistema de salvaguardas da AIEA.

Ronald Reagan deu continuidade à política nuclear de Carter, porém transferiu a ênfase da não proliferação de armas para o comércio de tecnologia nuclear ${ }^{217}$. Esse viés comercial implicou tentativa de transformar os Estados Unidos em um "fornecedor confiável” (ENERGY POLICY, 1983: 168) de tecnologia nuclear ${ }^{218}$ e conferir maior liberdade de atuação aos países do Norte Global nas suas políticas de cooperação nuclear, por meio, por exemplo, da não ingerência sobre suas práticas de reprocessamento de plutônio (ENERGY POLICY, 1983: 169).

Com o Brasil, tanto no governo de Figueiredo quanto no de Sarney, as relações com os Estados Unidos continuaram marcadas pela "baixa sintonia política" (HIRST, 2009: 50) e pela manutenção das tensões nos "temas de divergência", como tecnologias sensíveis (PECEQUILO, 2012: 43). Isso deveu-se, também, à pouca ênfase que a administração Reagan conferiu à América Latina em sua política externa e à categorização do Brasil como "um país que causa preocupação" (a country of

\footnotetext{
${ }^{214}$ BERGER, 29 jan, 1977

${ }^{215}$ SCIENCE, 18 fev. 1977

${ }^{216}$ SCIENCE, 18 fev. 1977

${ }^{217}$ ENERGY POLICY, jun. 1983

${ }^{218}$ A imagem dos Estados Unidos como fornecedor de tecnologia nuclear para países terceiros estava desgastada desde as mudanças legislativas no governo Nixon, as quais dificultaram a exportação de urânio enriquecido para países não membros do TNP.
} 
concerne $)^{219}$, apesar de sinalizações positivas daquele presidente no campo nuclear, como, por exemplo, a temporária permissão de utilização pelo Brasil de urânio importado de outros países em Angra I ${ }^{220}$.

Além disso, a inteligência americana durante o governo Reagan continuou a ver com desconfiança as visões do novo presidente, José Sarney, sobre o tema nuclear, na medida em que ele manteve as mesmas diretrizes de Figueiredo, devido aos acordos com os militares para a redemocratização ${ }^{221}$. Dessa forma, o panorama geral de restrições impostas pelos Estados Unidos ao acesso a tecnologias sensíveis e a pressão exercida por Washington ante os demais países fornecedores de tecnologia nuclear contribuíram para manter a desconfiança nas relações bilaterais nucleares e, assim, afastar o Brasil da possibilidade de cooperação imediata com Washington no campo atômico.

Com a Alemanha, a principal parceira do Brasil no campo nuclear desde o governo Geisel, as relações também se arrefeceram e passaram a se restringir ao cumprimento dos acordos já estabelecidos, com eventual indicação de manutenção da parceria comercial e possível efetivação de cooperação trilateral com países como a Argentina $^{222}$. Foi a Alemanha a uma das principais responsáveis, de imediato, pela desilusão ocorrida no governo Figueiredo, e mantida no governo Sarney, com relação às possibilidades de cooperação com o Eixo Assimétrico . Isso devido tanto ao fracasso das tentativas de cooperação junto à Inglaterra e à Holanda para realização de acordo com a tecnologia da URENCO quanto ao fracasso da tecnologia do jato centrífugo ${ }^{223}$ para usos comerciais em grande escala.

Bonn, ainda sob a chancelaria de Helmut Schmidt, também se distanciou do Brasil, apesar dos grandes esforços que dispensou na confecção do Acordo Brasil-

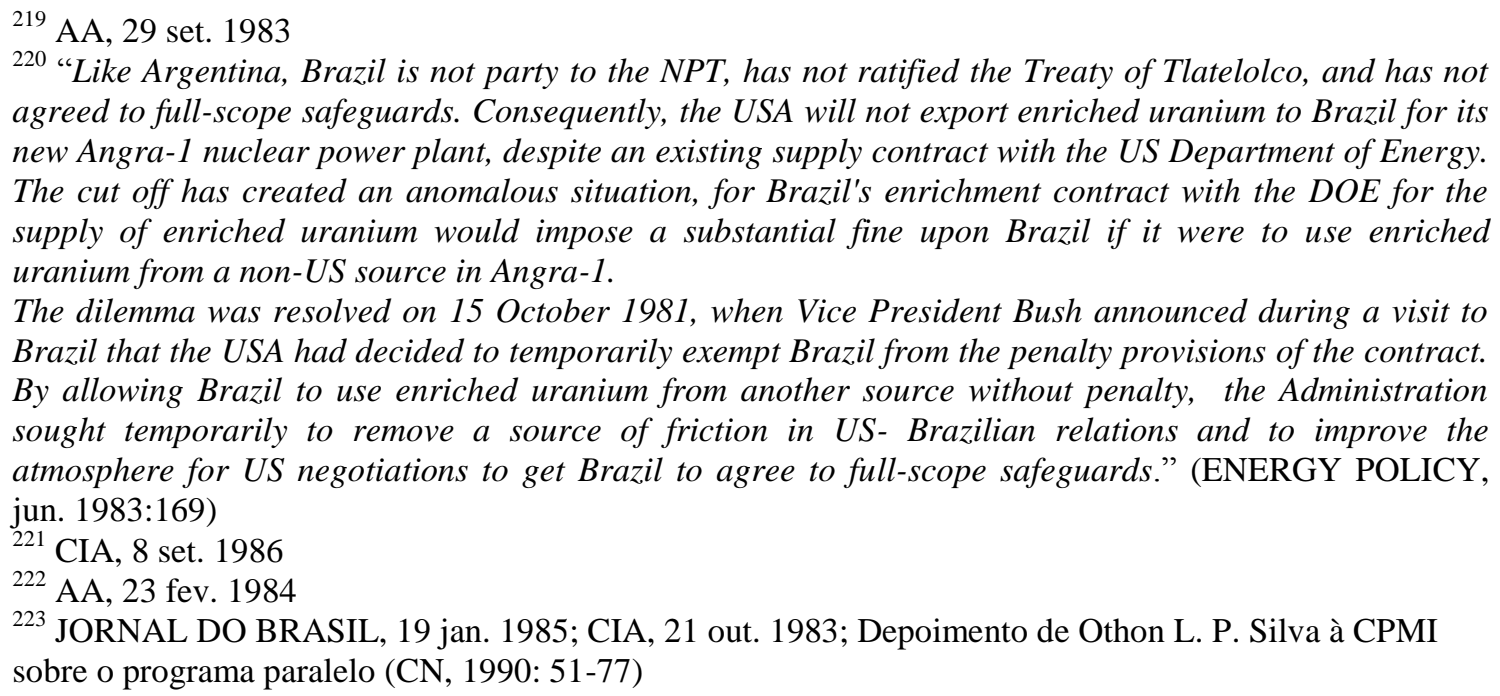
new Angra-1 nuclear power plant, despite an existing supply contract with the US Department of Energy. The cut off has created an anomalous situation, for Brazil's enrichment contract with the DOE for the supply of enriched uranium would impose a substantial fine upon Brazil if it were to use enriched uranium from a non-US source in Angra-1.

The dilemma was resolved on 15 October 1981, when Vice President Bush announced during a visit to Brazil that the USA had decided to temporarily exempt Brazil from the penalty provisions of the contract. By allowing Brazil to use enriched uranium from another source without penalty, the Administration sought temporarily to remove a source of friction in US-Brazilian relations and to improve the atmosphere for US negotiations to get Brazil to agree to full-scope safeguards." (ENERGY POLICY, jun. 1983:169)

${ }^{221}$ CIA, 8 set. 1986

222 AA, 23 fev. 1984

${ }^{223}$ JORNAL DO BRASIL, 19 jan. 1985; CIA, 21 out. 1983; Depoimento de Othon L. P. Silva à CPMI sobre o programa paralelo (CN, 1990: 51-77) 
Alemanha de 1975. Isso ocorreu após a inviabilização comercial do jato centrífugo e devido ao papel mais importante que passou a exercer na política alemã novos parceiros no setor nuclear, como o Irã ${ }^{224}$. O Brasil, contudo, continuou a exercer papel importante na consecução do sonderweg alemão, em especial devido à constituição de empresas binacionais que dariam à República Federal novo local para enriquecer urânio - o que a ela fora proibido fazer em seu próprio território, devido aos acordos de Paris de 1954. Dessa forma, ao menos do âmbito discursivo, Bonn manteve sua posição de diferenciar os casos do Brasil e Argentina daqueles da Índia e do Paquistão ${ }^{225}$, afirmando que o aqueles já estavam suficientemente salvaguardados por acordos trilaterais com a AIEA, ao passo que estes nunca foram suficientemente abarcados pelo regime internacional de não proliferação nuclear.

No governo Sarney, o programa de cooperação com a Alemanha Federal foi ainda mais fortemente minado, de modo a tornar-se pouco operativo. Das oito usinas previstas, apenas uma fora construída, Angra II, e das seis empresas instituídas pelo acordo, apenas duas (NUCLEN e NUCLEP) mantiveram-se operantes, sendo três (NUCLAM, NUCLEI, NUCLEMON) incluídas no plano de desestatização de 1988. Na prática, então, a cooperação com a Alemanha foi, gradualmente, desmontada, passando a se restringir a um pequeno grupo de instituições, cuja mais importante era Angra II. Em 1994, inclusive, o Acordo de 1975 será substituído por novo acordo bilateral, menos abrangente e menos impositivo na questão das salvaguardadas, porquanto essas já teriam sido englobadas pelo acordo Quadripartite, de $1991^{226}$.

\section{A aproximação com a Argentina: o Eixo Regional.}

Diferentemente do que ocorreu com os países do Eixo Assimétrico, o Eixo Regional tornou-se crescentemente mais relevante a partir do governo Figueiredo e, em especial, do governo Sarney. Após a "conjuntura crítica" (SPEKTOR, 2002) que marcou o governo Geisel, passou-se a verificar, desde a administração Figueiredo, crescente aproximação entre Brasil e Argentina, à qual levaria às bases da conformação da cooperação estratégica (SARAIVA, 2012) entre as partes, nos governos Collor e Menem. Esse processo terá como atores fundamentais os presidentes de ambos os

\footnotetext{
${ }^{224}$ AA, 25 mai. 1976

${ }^{225}$ DEUTSCHER BUNDESTAG, 12 dez. 2007

${ }^{226}$ DEUTSCHER BUNDESTAG, 12 dez. 2007
} 
países, em especial Sarney e Alfonsín, os quais sucederam seus antecessores militares após o conturbado episódio da Guerra das Malvinas.

O início do governo Figueiredo pautou-se por resquícios do afastamento entre Brasil e Argentina verificado no governo Geisel, com, ainda, incipiente aumento das tensões bilaterais, as quais poderiam levar, inclusive, a eminência de corrida armamentista regional (LEALI, MALTCHIK, 2015). A aproximação mais ampla entre os dois países somente começou a materializar-se após a solução do contencioso das cataratas (CASARALES, 1998; LIMA, 2013), em especial após visita do general Figueiredo à Argentina de Videla. A solução da crise Itaipu-Corpus, com o Acordo Tripartite entre Brasil, Argentina e Paraguai, assinado em outubro de 1979 abriu espaço para a cooperação em outras áreas (LAFER, 2004), como a militar e a nuclear.

Exemplo disso é a materialização do primeiro acordo de cooperação nuclear argentino-brasileiro (Acordo de Cooperação entre o Governo da República Federativa do Brasil e o Governo da República Argentina para o Desenvolvimento e a Aplicação dos Usos Pacíficos da Energia Nuclear), assinado por Figueiredo e Videla em 1980, em Buenos Aires. Esse acordo representou o primeiro ponto de aproximação entre os países, em particular por prever, entre outros pontos, o intercâmbio de informações entre os países (artigo V) e a colaboração e fechamento de convênios entre órgãos responsáveis pela condução das políticas nucleares nacionais (artigo IV). Isso teria aberto espaço, inclusive, para a maior proximidade entre os setores militares de ambos os países ligados ao desenvolvimento de energia nuclear para fins múltiplos ${ }^{227}$, inclusive explosões pacíficas, e a posição crítica de afastamento com relação aos Estados Unidos.

De fato, as explosões pacíficas constituíram ponto de contato entre os discursos das políticas externa argentina e brasileira na década de 1980 (REDRICK, 1975; CIA, 21 out. 1983) e ambos os países buscaram, por meio de programas nucleares paralelos e desconectados de salvaguardas internacionais. Como defendiam, abertamente, o direito dos países em desenvolvimento a realizarem explosões pacificas, configurou-se, na região do Cone Sul, iminência de corrida armamentista nuclear (SPEKTOR, 2015), a

\footnotetext{
${ }^{227}$ Assim como o Brasil, a Argentina implementou programa nuclear autônomo para o desenvolvimento de tecnologia atômica para fins múltiplos, o qual, apesar da instabilidade crescente da politica argentina, já demonstrada no capítulo anterior desta dissertação, manteve continuidade na sua condução pela CEA e nos seus objetivos iniciais. Esse desenvolvimento do programa paralelo ocorreu na usina experimental de reprocessamento de urânio de Pilcaniyeu, a qual se afirma teria sido "desconhecida das autoridades brasileiras e dos próprios serivos de informação ocidentais, (...) tampouco estava submetida às salvaguardas da" AIEA durante a década de 1970 e até meados da década de 1980 (VARGAS, 1997: 47)
} 
qual abarcou Brasil, Argentina e Chile ${ }^{228}$, este com capacidade de desenvolvimento de tecnologia nuclear altamente inferior àqueles (CARASALES, 1996).

Entre Brasil e Argentina, essa iminente corrida armamentista afetou, em especial, em um momento inicial, a diplomacia brasileira, a qual já percebia "desequilíbrio geopolítico com relação à Argentina” (MRE. 06 maio 1985) no campo nuclear, embora a capacidade brasileira excedesse aquela de Buenos Aires na maioria das outras áreas de relevância, inclusive as próprias forças armadas. Esse desequilíbrio decorria do reconhecimento brasileiro de que a Argentina era "líder absoluta nesse campo na América Latina", além de ser "o mais forte candidato do Terceiro Mundo ao ingresso no 'Clube de Londres', que reúne as potência nucleares" (CSN, apud LEALI, MALTCHIK, 2015:3-4).

Essas considerações sobre a capacidade nuclear argentina teriam instado, de modo complementar, o governo Figueiredo a patrocinar o desenvolvimento do programa nuclear paralelo (LEALI, MALTCHIK, 2015). Isso ocorreu porque, o desequilíbrio geopolítico, conceito caro aos militares formados na ESG, então favorável ao Brasil, penderia fortemente para Buenos Aires, caso a Argentina obtivesse armamentos nucleares. Isso ocorreria, pois "ainda que [o explosivo nuclear fosse] manufaturado para aplicação em fins pacíficos, isto por si só inevitavelmente acarretaria uma corrida nuclear de cunho armamentista, dada a impossibilidade de uma distinção prática entre o caráter pacífico ou militar de um explosivo nuclear."229.

No que concerne à posição com relação a Washington, Brasil e Argentina compartilharam distanciamento e de desilusão, com relação aos possíveis benefícios advindos da cooperação com a superpotência. Apesar de, nos anos 1960, ambos os países terem buscado desenvolver tecnologia nuclear em parceria com Washington nos anos 1960 e $1970^{230}$, no campo nuclear, a década de 1980 pautou-se pela crescente desconfiança de Buenos Aires e de Brasília com relação aos Estados Unidos, em

\footnotetext{
${ }^{228}$ Sobre o Chile, vale ressaltar que seu programa nuclear estava substancialmente mais atrado do que o brasileiro e o argentino (REDRICK, 1975); contudo mantinha uma política nuclear incisiva, defensora de princípios similares aos do Brasil e da Argentina e, conforme destacou o embaixador argentino Júlio Carasales, em conferência realizada pelo ISIS (CARASALES, 1996), somente aderiu ao TNP em 1992, ao mesmo tempo que Brasil e Argentina.

${ }^{229}$ MRE, 10 jan. 1985

${ }^{230}$ Enquanto, no caso brasileiro, como demonstrado pelo capítulo 2 desta dissertação, foi firmada parceria exitosa com os Estados Unidos, da qual decorreu a construção de Angra I pela Westinghouse; no caso argentino, as tratativas com os Estados Unidos não foram concretizadas e foram firmadas parcerias, respectivamente, com a Alemanha (Siemens), para a construção de Atucha I, entre 1968 e 1974; e com o Canadá, para a construção da Central Nuclear de Elbalse, em Córdoba, cuja construção se deu entre 1974 e 1984. Atucha II, também de tecnologia alemã, foi construída entre 2007 e 2014.
} 
especial durante o governo de Jimmy Carter o qual, para aqueles, ameaçava seus “interesses nacionais" (SPEKTOR, 2015: 4). Carter, portanto, teria, por meio de sua forte retórica contra a proliferação nuclear e da defesa intransigente dos direitos humanos, contribuído tanto para o afastamento dos dois principais países sulamericanos da órbita nuclear americana quanto para a aproximação entre esses dois países, visto que eles passaram a compartilhar posição contrária aos Estados Unidos.

Outro ponto relevante para o afastamento entre Buenos Aires e Washington foi a crescente aproximação da Argentina com a União Soviética. Apesar da retórica anticomunista dos governos militares, a partir do golpe de Estado liderado por Videla, a Argentina tornou-se, nos anos 1960 e 1970, o principal parceiro soviético na América Latina $^{231}$. Embora contraditória com os desenvolvimentos internos ocorridos durante a ditadura argentina, como, por exemplo, a perseguição a centrais sindicais (ROMERO, 2002; DE TITTO, 2008), a aproximação da Argentina com a União Soviética representou tentativa consciente de os militares afastarem-se das pressões americanas e, concomitantemente, reeditarem, pelo viés do "nacionalismo territorial" (RAPOPORT, SPIGUEL, 2005: 68) a tercera via peronista. Isso significava usar as relações a União Soviética para contrabalancear aquelas com Washington, de modo semelhante ao que, no Brasil, realizara Getúlio Vargas com sua "Eqüidistância Pragmática", na década de 1940 (MOURA, apud CERVO; BUENO, 2010).

O nacionalismo territorial também significou tentativa de os militares ampliarem sua aceitação em meio à opinião pública argentina, o que seria feito por meio da busca da união nacional em torno de inimigos externos comuns e do patriotismo relacionado à noção de unidade territorial. Esses inimigos externos, os quais teriam ocupado territórios pertencentes à Argentina, seriam o Chile, no Canal de Beagle, e o Reino Unido, nas Malvinas. O primeiro litígio adquiriu tom militar já no governo Videla, quando esse buscava controlar uma saída inter-oceânica, alternativa ao Canal do Panamá (RAPOPORT, SPIGUEL, 2005). Nesse caso, a expectativa era que o Chile obtivesse apoio dos Estados Unidos, ao passo que a Argentina da União Soviética, haja vista a presença de tropas pesqueiras russas e de outros países do Leste nas proximidades.

\footnotetext{
${ }^{231}$ Segundo Rapoport e Spiguel (2005: 62), "la ampliación y profundización de las relaciones con la URSS de los gobiernos de Videla y Viola, tanto en el plano económico como militar, pese al 'occidentalismo' proclamado por las FF.AA, fueran un fator decisivo para explicar la conflictividad con los EE.UU."
} 
O confronto entre Videla e Pinochet pelo Canal de Beagle levou a mobilizações militares de ambos os lados, mas, em meio a crescente oposição interna ao conflito, advinda de intelectuais, setores médios da sociedade e da Igreja (RAPOPORT, SPIGUEL, 2005: 59), o resultado final foi obtido, de modo pacífico, pela mediação do papa João Paulo II. Após o conflito, vale destacar, ambas as ditaduras, do Chile e da Argentina, viram-se grandemente enfraquecidas, tanto em termos de apoio popular e político quanto em termos econômicos.

Mesmo após a questão de Beagle, e buscando retomar certo apoio da população, o governo de Leopoldo Galtieri retomou a tese do nacionalismo territorial, agora com relação a outro contencioso de solução ainda mais complicada - as ilhas Malvinas, Geórgia do Sul e Sandwich do Sul. Iniciou-se assim, em 1982, a Guerra das Malvinas com o ataque argentino ao arquipélago (Operação Rosário), decisão tomada pelos militares com base na expectativa de que a reação de Londres fosse suficientemente demorada e pouco intensa, devido à distância entre a Grã-Bretanha e as Malvinas, e de que eles obteriam a mediação e o aval dos Estados Unidos, devido ao Tratado InterAmericano de Assistência Recíproca (TIAR) (CERVO; BUENO, 2010), bem como o respaldo soviético (RAPOPORT, SPIGUEL, 2005).

Acreditava-se, assim, que uma reação positiva das duas superpotências iria forçar Londres na direção de uma saída negociada, a qual reposicionaria "o Estado argentino na disputada e estratégica área do Atlântico Sul" (RAPOPORT, SPIGUEL, 2005: 68, tradução livre). Além disso, esperavam os militares amalgamar a opinião pública doméstica em torno da empreitada.

O resultado final da guerra foi, contrariamente ao esperado, o enfraquecimento do regime militar argentino e seu esgotamento político, que se somou ao esgotamento do modelo econômico. Parte relevante para esse resultado deveu-se às posições internacionais assumidas com relação ao conflito, em especial devido à posição americana favorável ao Reino Unido, argumentando que o TIAR não se aplicava à guerra, pois ela teria sido iniciada por ataque argentino. De fato, o apoio americano, já no governo Reagan, "asseguraria a vitória inglesa" (MORALES, 2012: 57, tradução livre) e a manutenção da "frente anticomunista" (MORALES, 2012: 69) entre Estados Unidos e Grão Bretanha, respectivamente sob Reagan e Thatcher. A União Soviética, por sua vez, apresentou-se, em âmbito discursivo, como favorável à causa argentina, porém não vetou a ação condenatória à opção do arquipélago no Conselho de Segurança 
da ONU, ao passo que todos os países da Comunidade Europeia apoiaram a Inglaterra (RAPOPORT, SPIEGEL, 2005: 69).

Ao contrário das posições dos países do Norte Global, os países do Sul, em especial Brasil, Peru, Cuba e os países-membro do Movimento dos Não Alinhados (RAPOPORT, SPIEGEL, 2005), mostraram-se mais abertos à posição argentina na Guerra das Malvinas. Apesar de não ter apoiado, explicitamente, Buenos no conflito, o governo de João Figueiredo teve posição e neutralidade imperfeita, favorável à causa argentina (SARAIVA, 2012). Essa postura favorável foi efetivada pelo suporte dado a navios e aviões argentinos e à recusa de prover espaço para reabastecimento de navios ingleses. Além disso, a embaixada brasileira em Londres assumiu a posição de representante oficial dos interesses argentinos, provendo, assim, canal de comunicação entre Buenos Aires e Londres e uniu-se à Argentina ao protestar contra o governo londrino pelo deslocamento de submarino nuclear a uma zona desnuclearizada ${ }^{232}$,qual seja, a América Latina (pelo Tratado de Tlatelolco) ${ }^{233}$.

A Guerra das Malvinas levou a duas consequências para o Brasil. Em primeiro lugar, ela levou à aproximação bilateral entre Brasil e Argentina, dando espaço para a superação da rivalidade latente e conformação futura de parceria estratégica. Isso ocorreu, principalmente, porque o Brasil foi um dos poucos países que manteve o apoio à causa argentina nas Malvinas, inclusive prestando apoio logístico no conflito. Mesmo após a queda de Reynaldo Bignone e do desgastado governo militar, as boas relações entre Brasil e Argentina mantiveram-se e, mesmo, fortaleceram-se. Essa aproximação também se deu no campo nuclear, com visitas cruzadas de inspetores nucleares nas usinas dos países vizinhos.

Em segundo lugar, a experiência argentina com a esquadra inglesa expôs ao Brasil a sua própria vulnerabilidade interna, em caso de ataque de uma grande potência estrangeira - vale lembrar a ocupação britânica da ilha de Trindade entre 1890 e $1896^{234}$. Entre outros fatores, essa vulnerabilidade foi percebida pela marinha brasileira como decorrência da posse britânica de submarinos nucleares (KASSENOVA, 2014), os quais teriam maior autonomia e seriam menos rastreáveis que os convencionais. Além disso, a Guerra das Malvinas mudou as hipóteses de guerra estudadas na ESG, de modo a mudar a ênfase da possibilidade de conflito externo da Argentina para possíveis

\footnotetext{
${ }^{232} \mathrm{CN}, 1990$

${ }^{233}$ Os protestos argentinos, com respaldos brasileiros, foram enviados à AEIA, a qual decidiu em parecer que a propulsão nuclear "não é arma, apenas substitui outro processo de propulsão" (CN, 1990: 73)

${ }^{234} \mathrm{CN}, 1990$
} 
ameaças extra-continentais (MONIZ BANDEIRA, 1989), inclusive os Estados Unidos (KASSENOVA, 2014).

Já ao final do governo Bignone, as relações bilaterais mostraram-se cada vez mais próximas no campo da energia atômica. Exemplo disso foi a realização do encontro entre a Associación Física Argentina (AFA) e a Sociedade Brasileira de Física (SBF), em novembro de 1983, nas quais já se aventou a possibilidade de evitar corrida armamentista regional por meio da criação de mecanismos de inspeções bilaterais mutuas (WROBEL, REDRICK, 1998: 176) ${ }^{235}$. Com a redemocratização no Brasil e na Argentina, as relações bilaterais tornaram-se ainda mais próximas. Essa aproximação já começou a dar sinais de preocupação no ambiente internacional, pois, ao invés da possibilidade de corrida armamentista no Cone Sul, começou-se a se aventar a possibilidade de que Brasília e Buenos Aires construíssem um explosivo nuclear binacional $^{236}$.

Essa possibilidade do explosivo bilateral não se concretizou, na medida em que as relações, tão mais se intensificavam, tão mais próximos os países se tornavam do regime internacional de não proliferação nuclear. Essa aproximação ocorreu ainda nos primeiros governos pós-redemocratização no Brasil e na Argentina, embora ainda se mantivesse, em princípio, certa desconfiança mútua, que implicava pragmatismo nas relações bilaterais, de modo a manter a cordialidade oficial dantes estabelecida. Essa desconfiança pode ser ilustrada pelo sobrevôo realizado por avião militar brasileiro à usina de Pilcaniyeu, poucos dias após a morte do presidente Tancredo Neves (GORCZESKI, 2015).

Essa desconfiança começou a ser dissipada nos governos Sarney e Alfonsín, que aprofundaram o processo de aproximação bilateral iniciado após a Guerra das Malvinas. Grande parte dessa aproximação deu-se por conta da atuação pessoal dos próprios presidentes, em especial de Alfonsín, o qual, inclusive, teria indicado a Sarney a possibilidade de constituição de mecanismo bilateral de troca de inspetores ${ }^{237}$. Sobre

\footnotetext{
${ }^{235}$ Nessa reunião conjunta, discutiram-se temas de interesse binacionais e regionais, como maneiras de se evitar corrida armamentista no Cone Sul e a possível instalação de arranjo conjunto de inspeções mútuas (WROBEL, REDRICK, 1998). Além disso, naquele ponto "for the first time, both physics societies began to share the view that some societal control over their respective nuclear programs was desirable, and that they should work to establish this objective" (WROBEL, REDRICK, 1998: 176)

${ }^{236}$ CARASALES, 16 maio 1996: 6

${ }^{237}$ Segundo o embaixador brasileiro em Buenos Aires, “(f)oi-me apresentada, a título inicial, uma ideia que o Presidente Alfonsín teria aflorado, preliminarmente, com o Presidente Tancredo Neves, quando da sua presença em Buenos Aires no inicio de Fevereiro último, qual seja a das novas dimensões da cooperação nuclear bilateral. Nesse sentido, os argentinos sugeriram que fosse examinada pelo Brasil e pela Argentina a criação de um sistema de controle bilateral das aplicações da energia nuclear num e
} 
esse tema, o governo Sarney ainda não haveria tomado medidas extensivas e a possibilidade implementar salvaguardas, contudo já avaliava o caráter crucial da sintonia política com a Argentina.

Essa sintonia dar-se-ia tanto no escopo das salvaguardas quanto no teor das declarações, pois, como afirmou o chanceler Olavo Setúbal em reunião com seu homólogo argentino, Dante Caputo (MRE, 20 maio 1985), "aceitar um sistema de inspeção que não vá às últimas consequências é uma decisão muito grave. Devem os dois países ou se limitar a declarações políticas ou aceitar inspeções totais, não há meio termo". Além disso, avaliava o governo brasileiro que a sintonia com a posição política argentina era clara, pois caso o governo Alfonsín decidisse se aproximasse unilateralmente do regime internacional de não proliferação nuclear ${ }^{238}$, em especial do TNP e do Tratado de Tlatelolco, o Brasil iria arcar, sozinho, com elevado ônus político (MRE, 06 maio 1985), esse decorrente da pouca capacidade do governo brasileiro de conduzir a política nuclear interna e os desenvolvimentos do programa paralelo. Dessa forma, fazia-se necessário a realização de declaração conjunta sobre o tema pelos presidentes Alfonsín e Sarney, a qual reafirmasse os princípios de ambos os países com os usos pacíficos da energia nuclear, inclusive para explosões pacificas.

A maior cooperação bilateral foi possível graças à supramencionada solução da questão do aproveitamento hídrico dos rios fronteiriços, ao enfraquecimento argentino após a Guerra das Malvinas e à busca brasileiro-argentina de retomar crescimento econômico e estabilidade, para o que era necessário criar condições para inserção competitiva no mercado internacional e para futura cooperação para instalação de fontes alternativas de energia nas matrizes energéticas de ambos os países ${ }^{239}$. Assim, embora o

noutro país, a ser criado exclusivamente no âmbito brasileiro-argentino, consoante padrões próprios a serem estabelecidos. Além dos objetivos de segurança que tal sistema de cooperação poderá atender, entendem os argentinos que ela tenderá a ampliar a capacidade" (MRE, 19-20 maio de 1985)"

238 Vale ressaltar que Alfonsín assumiu a Casa Rosada em processo de transição política bastante conturbado, no qual os militares detiveram papel de reduzido protagonismo político e de alta impopularidade (ROMERO, 2002), diferentemente do caso do Brasil, onde o processo foi, praticamente todo, conduzido pelas Forças Armadas por meio de acordos e de negociação, o que teria reduzido substancialmente a liberdade de atuação do presidente Sarney (O’DONNELL, 1988), que, além de eleito indiretamente, havia assumido o cargo devido à morte de Tancredo Neves.

239 “(O chanceler brasileiro, Olavo Setúbal,) afirmou que nos próximos 20 anos se esgotarão os recursos hídricos dos dois países que terão de recorrer então a fontes alternativas, provavelmente dispendiosas e de tecnologia restrita. Formar-se-ão mercados muito grandes para essas tecnologias, e em geral cativos. Se Brasil e Argentina não estiverem unidos "se continuarmos a nos confrontar (sic)", os mercados serão cativados pelos fornecedores tradicionais. "Temos de eliminar o problema de construção de bombas, o que é disparate e uma insensatez", declarou, e devemos procurar valorizar a capacidade comum de cooperação em um campo de imenso potencial e de tecnologia de ponta, com possibilidade de que a cooperação se estenda a outros campos. As salvaguardas contra aplicações bélicas , afirmou, afetaram outras aplicações e são controladas pelas atuais potencias nucleares." (MRE, 20 maio de 1985)" 
governo Sarney houvesse mantido a ênfase no desenvolvimento autóctone de energia nuclear, não se pretendia eliminar tratativas futuras de negociações com o Norte Global.

Dessa forma, a aproximação Brasil e Argentina, nos governos Sarney e Alfonsín, consubstanciou-se na Declaração Conjunta sobre Política Nuclear para fins Exclusivamente Pacíficos, assinada em Foz do Iguaçu em 30 de novembro de 1985, na qual os mandatários reafirmaram o direito de desenvolver tecnologia nuclear para fins exclusivamente pacíficos e a criação de

\begin{abstract}
"Grupo de Trabalho conjunto sob a responsabilidade das Chancelarias brasileira e argentina, integrado por representantes das respectivas Comissões e empresas nucleares, para o fomento das relações entre os dois países nessa área, a promoção de seu desenvolvimento tecnológico-nuclear e a criação de mecanismos que assegurem os superiores interesses da paz, da segurança e do desenvolvimento da região, sem prejuízo dos aspectos técnicos da cooperação nuclear que continuarão sendo regidos pelos instrumentos vigentes." (BRASIL, ARGENTINA, 1985).
\end{abstract}

A declaração de Iguaçu sobre Política Nuclear foi reafirmada na Declaração Conjunta sobre Política Nuclear entre o governo da República Federativa do Brasil e o governo da República Argentina (Declaração de Viedma), de 1987, e na Declaração Conjunta sobre Política Nuclear de Ezeiza, de 1988. Além disso, os governos teriam expressado a intenção de colaborar no campo do ciclo do combustível nuclear ${ }^{240} \mathrm{e}$, em 1986, a Comissão Vargas recomendou "estabelecer gradualmente mecanismo de inspeção mútua das atividades de ambos os países" (ABACC, 1993: 4). Igualmente relevantes foram as visitas realizadas por Sarney, em 1987, à central de Pilcaniyeu e por Alfonsín, em 1988, à base de Aramar, em Iperó, São Paulo, esta precedida por visita de funcionários argentinos às instalações do IPEN, em dezembro de 1986, o qual, "tal como Pilcaniyeu (...) [,] não estava submetido às salvaguardas da AIEA” (VARGAS, 1997: 51-52).

Ao final da década de 1980, ressalta-se por fim, as relações com a Argentina haviam atingindo tal ponto de proximidade que, previamente à publicização do programa nuclear paralelo, Sarney enviou mensagem à Casa Rosada informando a Alfonsín dos avanços tecnológicos brasileiros e do anúncio vindouro ${ }^{241}$. Essa atitude, semelhante àquela tomada pelo presidente Bignone em $1983^{242}$, representou a confirmação da aproximação bilateral, que se firmava no âmbito das administrações federais de ambos

\footnotetext{
${ }^{240}$ ABACC, 1993

${ }^{241}$ MRE, 4 set. 1987

${ }^{242}$ Em 1983, o presidente Bignone mandou carta a Figueiredo informando que a Argentina havia desenvolvido tecnologia para enriquecimento de urânio (MRE, 18 nov. 1983).
} 
os países e na esfera institucional. Delineava-se a cooperação estratégica, a qual será consolidada, no campo nuclear e econômico, no período posterior, com a ABACC e o Mercosul.

\section{Cooperação Horizontal para tecnologia sensível: o Eixo Sul (Iraque, China, África do Sul, México)}

Assim como a aproximação com a Argentina, o período entre 1979 e 1989 caracterizou-se pela busca de diversificação das parcerias no campo nuclear, de modo a abranger países com os quais o Brasil tinha pouco contato prévio e com os quais buscava aproximar-se desde os anos 1960, pela Política Externa Independente (VIZENTINI, 1998). São esses os países periféricos, ou do Sul Global, com os quais o governo brasileiro, em especial durante o governo Figueiredo, buscou desenvolver aproximação bilateral no campo da energia nuclear, capaz tanto de suprir insumos necessários para a manutenção do programa nuclear autônomo quanto de adquirir mercado consumidor para a tecnologia nuclear desenvolvida nacionalmente.

O Eixo Sul foi utilizado pelo governo Figueiredo e, em menor escala, pelo governo Sarney, de modo a tentar obter compensação pelo afastamento do Norte Global, com relação ao qual o Brasil enfrentava processo de gradativo afastamento no campo nuclear. Por meio do Eixo Sul, os representantes brasileiros buscaram, por exemplo, obter urânio enriquecido para o desenvolvimento de tecnologia nuclear de usos múltiplos (acredita-se que da China), conformar alianças o desenvolvimento de tecnologia própria de enriquecimento de urânio (Iraque e África do Sul), obter mercado para tecnologia desenvolvida nacionalmente, ou em parceria com a Alemanha, pelo Acordo de 1975 (México) $^{243}$.

A questão do urânio enriquecido é tema de difícil acesso em documentações e controverso, porquanto se trata de informação considerada sensível e de interesse nacional. Ainda hoje, a questão do urânio obtido para uso pelo programa autônomo é tema de controvérsias e pouco divulgado. Embora os projetos Ciclone e Atlântico e, em

\footnotetext{
${ }^{243}$ No que toca aos países selecionados para abordar nesta seção, vale destacar que se tratou de escolha realizada com base na pesquisa bibliográfica e documental realizada pelo autor. Acredita-se que são esses os mais elucidativos do Eixo Sul, apesar da existência de outros países que poderiam aqui ter sido incluídos, como a Bolívia, com a qual o Brasil buscou negociações no campo de transferência futura de tecnologia nuclear (14 de maio de 1974), como a Venezuela, com a qual o Brasil firmou acordo de cooperação para usos pacíficos da energia nuclear, em 1983, e como a Líbia, com a qual o Brasil ensaiou venda de material radioativo e cooperação tecnológica.
} 
particular, o PROCON, tivessem como objetivo conferir ao conjunto do programa autônomo insumos básicos como urânio enriquecido, o qual deveria, inclusive, ser utilizado pelo Projeto Solimões para o desenvolvimento de artefatos para explosões pacíficas, buscou-se obter fontes alternativas. Isso seria necessário para garantir a continuidade do desenvolvimento de tecnologia nos quatro programas patrocinados pelas Forças Armadas ${ }^{244}$, em especial aquele da Aeronáutica.

Esse urânio clandestino teria sido obtido por meio do meio de acordo secreto firmado com um país, cujo nome não poderia ser divulgado, por exigência daquele, e o qual reivindicou que o material nuclear fosse utilizado, somente, para fins pacíficos ${ }^{245}$. Sobre esta questão, vale relembrar que, na perspectiva jurídica e política brasileira, esses fins incluiriam explosões pacíficas ${ }^{246}$. Segundo suspeitas levantadas na CPMI sobre o programa paralelo (CN, 1990: 101), confirmadas pelo ex-presidente da CNEN do Governo Collor ${ }^{247}$, o urânio obtido clandestinamente pelo governo seria oriundo da República Popular da China, país com o qual o governo brasileiro havia normalizado relações diplomáticas no governo Geisel e com o qual o governo firmou acordo de cooperação para usos pacíficos da energia nuclear em 11 de novembro de 1984, bem como país considerado o principal provedor de assistência nuclear para países em desenvolvimento (NEDAL, 2015). Além disso, em visita do Primeiro-Ministro chinês ao Brasil, o então presidente Sarney destacou que as posições semelhantes entre Brasil e China na área da política nuclear ensejariam um "futuro promissor" 248 na área de cooperação.

Nesse sentido, vale ressaltar que já se previa no artigo VI do acordo de 1984 com a China a possibilidade de o Brasil importar urânio e tecnologia atômica chinesa, desde que salvaguardados pela AIEA $^{249}$. Oito meses antes de firmado aquele acordo, em abril

\footnotetext{
${ }^{244}$ Discussão entre o deputado Mauro Campos e o general Danilo Venturini na CPMI sobre o programa paralelo (CN, 1990: 24-25)

245 "Em sua resposta [às indagações do deputado Mauro Campos], o General Danilo Venturini disse: '[...], Acontece que o urânio enriquecido a que V. Exa. Se refere, que encontrou na instalação de Aramar, foi negociado com um país. Como parte do acordo explicito feito com esse país, exigiu-nos, como condição, duas premissas: a primeira, o sigilo, que o nome desse país fosse guardado; e a segunda, o compromisso explicito de que esse urânio só seria utilizado para fins pacíficos.” (CN, 1990: 24-25)

246 "Last year an agreement between the governments of Brazil and the Popular Republic of China was signed for the exchange of technology that will permit the development of attack missiles with atomic warheads using solid fuel, similar to the ones used by the USA in the 60's." (FOLHA, 08 ago. 1986)

${ }^{247}$ Entrevista de José Luiz de Santana Carvalho, concedida ao autor em 18 de fevereiro de 2016.

${ }^{248}$ SARNEY, 31 outubro 1985

249 "Todo o material ou equipamento fornecido nos termos do presente Acordo por uma Parte à outra, ou o material obtido pelo uso desse material ou equipamento, ou o material utilizado no equipamento fornecido nos termos do presente Acordo, só deverá ser utilizado com finalidades pacíficas e não deverá ser usado para a manufatura ou desenvolvimento de armas nucleares ou para qualquer finalidade militar.
} 
de 1984, contudo, o chanceler Saraiva Guerreiro relembrava, em correspondência enviada ao presidente Figueiredo, a visita do presidente da CNEN à China, em dezembro de 1982, com o "objetivo de concertar a compra pelo Brasil de urânio enriquecido" e afirmava ser vantajoso ao Brasil associar-se para esse fim com Pequim, porquanto o urânio enriquecido seria entregue "sem as exigências normalmente feitas por outros fornecedores relativas a controles tipo salvaguardas 'full scope" "250. Além disso, lembrava-se que, apesar de ter ingressado na AIEA, a China havia mantido "sua postura contraria ao regime de não-proliferação horizontal prevista no TNP" e que o Brasil já havia contratado a aquisição de urânio "cuja remessa ao Brasil deverá ser realizada proximamente" 251 .

Acredita-se, assim, apesar de a China ter negado haver fornecido tecnologia nuclear ao Brasil ${ }^{252}$, existem fortes indícios para acreditar que o Brasil tenha importado, durante o governo Figueiredo, urânio enriquecido da China, com o objetivo de fornecer insumos para o programa nuclear autônomo. Esse urânio seria enriquecido a nível de bomba (mais de $90 \%)^{253}$, porém ainda em grau sujo, ou seja, poderia ser utilizado, tão somente, para fazer uma "bomba suja",254. Com o processo de decaimento natural do urânio, boa parte desse material teria deixado, com o passar dos anos, de ser altamente enriquecido e teria sido, na década de 1990, salvaguardado pela AIEA, por meio da ABACC ${ }^{255}$. Outra possibilidade é que esse urânio enriquecido possivelmente transferido ao Brasil não fosse em grau bomba, porém tivesse grau suficientemente elevado, a ponto de

As Partes Contratantes se comprometem a solicitar à Agência Internacional de Energia Atômica a aplicação de salvaguardas em relação aos materiais nucleares ou equipamento transferidos nos termos do presente Acordo, ou em relação a material especial fissionável obtido pelo uso dos materiais e equipamento acima referidos" (BRASIL, CHINA, 1984. Artigo VI).

${ }^{250}$ MRE, 04 abril 1984: 2

${ }^{251}$ MRE, 04 abril 1984: 2

${ }^{252}$ Emb. Argentina, 24 out. 1985

${ }^{253}$ Segundo entrevista realizada com José Luiz de Santana Carvalho, em 18 de fevereiro de 2016, cuja íntegra encontra-se anexa.

${ }^{254}$ A bomba suja é uma arma radiológica que combina material radioativo com explosivos convencionais, diferentemente das bombas nucleares tradicionais, por fissão ou por fusão nuclear.

${ }^{255}$ Segundo entrevista escrita concedida ao autor pelo antigo inspetor da ABACC, Silvio de Almeida, em 25 de fevereiro de 2016, cuja íntegra encontra-se anexa, sobre o urânio obtido para abastecimento do programa paralelo: "pelo que sei, já no início do SCCC e do Acordo Quadripartite todos os materiais nucleares tiveram que constar das listas de inventários enviadas para as agências. E, se por acaso, algum material, por algum descuido tenha ficado fora dela, certamente com este tempo todo já foi incorporado ao inventário e declarado, nesse caso, como um ganho acidental de material nuclear. Lembro-me vagamente de certa quantidade de urânio proveniente da China, mas esse material também foi declarado para a ABACC e, consequentemente para a AIEA. Pelo que sei, por ser de alto enriquecimento, esse material sofreu redução deste enriquecimento transformando-se em material de baixo enriquecimento para uso em algum processo e, portanto, não tem nada de clandestino. Desconheço quaisquer evidências que conduzam à possibilidade de haver material clandestino e, particularmente, não creio que nem Brasil e nem Argentina se arriscariam a manter até hoje algum material que já não tivesse sido declarado para a ABACC e AIEA, desrespeitando os acordos em vigor (SCCC e INFCIRC/435)." 
permitir seu enriquecimento por meio das centrífugas brasileiras, obtidas no momento 1969-1978.

Além da China, outro país com o qual houve breve ensaio de cooperação sigilosa no campo nuclear foi a África do Sul segregacionista. Nesse caso, não se acredita ter sido desenvolvido intercâmbio real de tecnologia ou de material radioativo, mas que houveram, apenas, sinalizações positivas de Pretória na direção de constituir acordo de cooperação com o Brasil. Diferentemente do que ocorreu no caso da China e, como se verá, do Iraque, na década de 1980, Brasília apresentava sinais de distanciamento progressivo da África do Sul nas esferas política e de cooperação, devido à intensificação da pressão da comunidade internacional contra o regime do apartheid, além do que, desde o governo Geisel, o Brasil havia buscado aproximar-se política e comercialmente dos demais países africanos, enfaticamente contrários ao governo bôer (PENNA FILHO, 2013).

No campo atômico, documentos do MRE apontam para uma sondagem feita pelo governo sul-africano, por meio do seu embaixador em Bonn, para a possibilidade de intercâmbio de informações sobre desenvolvimento de tecnologia nuclear entre Pretória e Brasíliaa ${ }^{256}$. Afirmava o embaixador que ambos os países possuíam grandes semelhanças, porquanto eram países periféricos, desenvolvimento métodos autônomos de enriquecimento de urânio, além de o método sul-africano ser semelhante àquele do jato centrífugo ${ }^{257}$, que havia fracassado no Brasil. Seria, portanto, uma segunda oportunidade de viabilização do jato centrífugo, a qual não foi considerada vantajosa pelo Brasil e a qual corrobora a tese da desilusão brasileira, na década de 1980, com o Eixo Assimétrico .

Diferentemente da China e da África do Sul, que representaram tratativas sigilosas consideradas pelo governo brasileiro, as relações com o Iraque e com o México foram não só ostensivas como também instrumentalizadas para aumentar o prestígio brasileiro ante a comunidade internacional, na medida em que corroborariam o Brasil o escopo universalista (VIZENTINI, 1998) da política externa brasileira. Além disso, foram relações regidas por motivações diretamente comerciais e voltadas para a obtenção de insumos para a industrialização brasileira (como o petróleo, no caso iraquiano, e mercado consumidor, em ambos os casos).

\footnotetext{
${ }^{256}$ MRE, 05 nov. 1979

${ }^{257}$ MRE, 16 maio 1979
} 
A opção de cooperar no setor nuclear com o país de Saddam Hussein começou a ser aventada, por iniciativa iraquiana, ao final do governo Geisel e se enquadra nos esforços brasileiros de diversificar sua pauta exportadora àquele país, então altamente deficitária para o Brasil e reduzida, quase que exclusivamente, à importação de petróleo (FARES, 2007). O governo iraquiano era o principal fornecedor de petróleo ao Brasil (FARES, 2007; TRAUMANN, 2011), insumo essencial para a estratégia brasileira de desenvolvimento, e, pelo tamanho de sua população e potencial de crescimento econômico, também era um dos principais parceiros do Brasil no exterior seguramente, o maior no Oriente Médio. Durante as décadas de 1970 e de 1980, o Iraque foi o maior importador de serviços de engenharia e de produtos industrializados brasileiros (TRAUMANN, 2011), além de grande receptor na área de cooperação científica e educacional. O comércio bilateral era facilitado pelo barter trade, uma “espécie de escambo de petróleo por mercadorias" (TRAUMANN, 2011, p. 2), similar ao método do comércio compensado, implementado pelo governo Vargas com a Alemanha hitlerista.

Com o Choque do Petróleo de 1973 e, principalmente, de 1979, o Iraque se tornou alvo das preocupações de Brasília, à medida que a balança comercial se tornava cada vez mais deficitária, devido ao súbito aumento do preço do barril de petróleo. Nesse contexto, a cooperação nos setores bélico e nuclear tornaram-se alternativas relevantes a serem consideradas, haja vista o crescimento da indústria bélica brasileira e os avanços no setor nuclear, em especial advindos de pesquisas realizadas pelo programa autóctone. No final do governo Geisel, porém de forma mais intensa no governo Figueiredo, o Iraque tornou-se relevante receptor de armas brasileira, por meio de empresas como IMBEL e ENGESA ${ }^{258}$.

No campo nuclear, cuja cooperação seria espécie de troca para obter maior facilidades no acesso ao petróleo, o programa conjunto possuía, "provavelmente, finalidade militar" (FARES, 2007b: 6). Em 12 de março de 1980, foi assinado em Bagdá acordo que objetou estabelecer entre Brasil e Iraque

\footnotetext{
"ampla cooperação no desenvolvimento de energia nuclear para fins pacíficos, principalmente no tocante a estudos de avaliação de reservas de urânio, sua prospecção, exploração, mineração e beneficiamento; fornecimento de urânio natural e levemente enriquecido; e fornecimento de equipamentos e serviços de engenharia e construção de reatores nucleares" (SF, 1982: 20).
}

${ }^{258}$ JORNAL DO BRASIL, 25 abril 1974 
A parceria com o Iraque, dessa forma, abrangeu termos semelhantes àqueles do acordo de 1975 com a Alemanha Federal. Com Bagdá, porém, o Brasil aparece como parceiro horizontal, também do Sul Global, o qual possuía, contudo, maior conhecimento técnico sobre o campo nuclear. Isso é importante, porque revela novo formato de cooperação no campo nuclear, ou seja, desenvolver tecnologia de enriquecimento em conjunto com país que, apesar de não controlar essa tecnologia, poderia complementar os esforços brasileiros. Essa complementação seria possível porque enquanto o Brasil transmitiria ao Iraque conhecimento tecnológico obtido da Alemanha Federal, os iraquianos transfeririam ao Brasil tecnologia obtida da França ${ }^{259}$. Vale salientar que, ao consultar Bonn sobre o acordo com o Iraque, "os parceiros alemães mostraram-se receptivos à cooperação (...), admitindo participação direta ou indireta"260. A cooperação com o Iraque tratou-se, portanto, de cooperação entre semelhantes, assim como aquela ensejada por Pretória.

Para o Iraque, o Brasil enviou técnicos da CNEN, especializados na área tecnologia nuclear e com experiência obtida dos acordos com a Alemanha e com os Estados Unidos na década anterior. Além disso, a imprensa brasileira teria divulgado evidencias de transporte secreto de "dióxido de urânio não salvaguardado do Brasil para o Iraque em 1981" (CIA, 21 out. 1983, tradução livre). Devido à falta de recursos financeiros que o Brasil passou a sofrer, especialmente, no governo Sarney e devido a mudanças de prioridade iraquianas após a Guerra Irã-Iraque (1980-1988) e a Guerra do Golfo (1990-1991), a cooperação bilateral foi descontinuada e, na década de 1990, abandonada.

Também de forma ostensiva, o Brasil buscou cooperação bilateral com o México, com o objetivo de conseguir mercado para a Nuclebrás e suas subsidiárias ${ }^{261}$. A ideia era que o México ingressasse no sistema de jato centrífugo, o qual, em 1979, acreditava o governo, ainda poderia ser comercializado, pelo menos no que concerne a

\footnotetext{
${ }^{259}$ MRE, 17 jan. 1979.

${ }^{260}$ MRE, 17 jan. 1979.

${ }^{261}$ Sobre o México, vale lembrar a existência de mudança de perspectiva com relação à proximidade com esse país no campo nuclear. Durante a gestão de Azeredo da Silveira, segundo entrevista concedida por Luiz Lampreia ao CPDOC-FGV (1 ${ }^{a}$ entrevista, 6 jan. 2008: 37), "no foro multilateral, se jogava com a Índia sim, sem dúvida. A nossa aliança principal era com a Índia mesmo, sem dúvida, e contra o México. O México encarnava ao contrário, não é? Entre os países em desenvolvimento importantes, era o país que mais preconizava o TNP, com o Garcia Robles, que depois ganhou o Prêmio Nobel da Paz. Ele era o delegado mexicano na Comissão do Desarmamento, em Genebra". Isso significa que a posição mexicana extremamente favorável ao TNP contrariava a posição brasileira, de modo a haver, no tema do desarmamento, conflito entre os dois maiores países da América Latina.
} 
alguns equipamentos usados para o enriquecimento de urânio ${ }^{262}$. A cooperação ocorreria entre a Nuclebrás e a URAMEX ${ }^{263}$ ocorreria por meio de licitação pública do governo mexicano, na qual a estatal brasileira entraria com "sistema nuclear de geração de vapor, incluindo os tubos do sistema primário da central" ${ }^{264}$., ao passo que a transferência tecnológica nas áreas de fabricação de elemento combustível e de armazenamento seriam fornecidos pela $\mathrm{KWU}^{265}$.

A participação da KWU era requisito exigido pelo acordo de 1975, bem como foi estratégia utilizada pela Nuclebrás para tornar-se competitiva no processo licitatório mexicano. À KWU foi acrescida, para a viabilização do acordo com o México, a participação da empresa também alemã STEAG $^{266}$, bem como foi acordado a possibilidade de o governo mexicano tornar-se acionário minoritário de uma usina de enriquecimento de urânio por jato centrífugo da Nuclebrás no Brasil ${ }^{267}$. A concorrência internacional para a licitação, que abrangia a construção de quatro usinas no México, abarcou três empresas americanas (Westinghouse, General Electric, Combustion Engineering), uma francesa (Franatoire), uma alemã e brasileira (KWU-Nuclebrás), uma canadense (Atomic Energy of Canada) e uma sueca (ASEATON). Em 1982, a Comissão Federal de Eletricidade do México suspendeu a concorrência internacional, o processo de licitação e devolveu as propostas às respectivas empresas ${ }^{268}$.

O processo de negociação com o México representou tentativa brasileira de reavivar o programa oficial e de viabilizar o sistema de enriquecimento de urânio por jato centrífugo, que já dava sinais de inviabilidade comercial, o que seria um dos elementos a incitar a desilusão com o Eixo Assimétrico . A cooperação com o México também foi passo importante na reafirmação da posição brasileira ${ }^{269}$, pois tratou de

\footnotetext{
${ }^{262}$ NUCLEBRÁS, 12 mar. 1979.

263 A URAMEX tratou-se de empresa estatal mexicana criada em 27 de janeiro de 1979 e fechada em dezembro de 1984. Sua breve existência marcou um breve período de busca de autonomia na política externa e energética mexicana, nos governos de Joe López Portillo (1976-1982) e início de Miguel de La Madrid (1982-1988) (BONILLA, 8 jan. 1985). Ela tinha como objetivo, juntamente com a Comisión Nacional de Energia Nuclear e com o Instituto Nacional de Investigaciones Nucleares, desenvolver capacidade nacional de produção de energia nuclear pela via estatal. Contudo, em 1984 a nova Ley Nuclear, que continha cerca de "30 modificações feitas no projeto apresentado pelo presidente" (BONILLA, 8 jan. 1985, tradução própria), modificou a estratégia de inserção do México no mercado nuclear global, a qual passaria a ser feita por empresas privadas.

${ }^{264}$ NUCLEBRÁS, sem data.

${ }^{265}$ NUCLEBRÁS, 12 mar. 1979.; NUCLEBRÁS, sem data

${ }^{266}$ NUCLEBRÁS, jan. 1982

267 "NUCLEBRAS/STEAG are prepared to give the relevant Mexican Institutions the possibility of their participation as a minority shareholders in a NUCLEBRAS Nozzle enrichment plant in Brazil, under terms and conditions to be agreed upon, including assurances of supply" (NUCLEBRÁS, jan. 1982)

${ }^{268}$ NUCLEBRÁS, 22 jun. 1982

${ }^{269}$ MRE, sem data
} 
negociação com país com posição radicalmente distinta da brasileira, como mostrado no Quadro 7. Com isso, o Brasil mostrava que, não obstante a não assinatura do TNP e a não ratificação do Tratado de Tlatelolco, era parceiro confiável em temas de tecnologia sensível $^{270}$, pois conseguiria firmar acordo com o principal promotor das instituições de proscrição de armas nucleares da América Latina.

Quadro 7 - Posições do Brasil e do México em 1969 (entrada em vigor do Tratado de Tlatelolco)

Posição com relação ao

Tratado de Tlatelolco

Posição com relação aos

protocolos adicionais I e

II a Tlatelolco.

Interpretação do artigo

18

Relação com a OPANAL.

Margem de

Entendimento

Assinou e ratificou o Tratado, mas este não entrou em vigor, porque o Brasil

Condiciona sua ratificação à firma pelas potências interessadas dos Protocolos Adicionais I e II

Dispensa a assinatura dos Protocolos Adicionais I e II.

Ao assinar o Tratado, depositou nota interpretativa sobre o artigo 18, afirmando que seu texto não nos cria limitações para realizar explosões nucleares para fins pacíficos.

Não participa da OPANAL.

Interpreta de forma restritiva o artigo 18.

É país sede e principal promotor da OPANAL.

"Escasso ou nula. O Brasil não abrirá mão de suas posições fundamentais nem o México das suas. Arma-se, nas Nações Unidas, ofensiva para fotalecer o Tratado de Tlatelolco e pressionar o Brasil, Argentina e Chile para que abandonassem suas reservas e qualificações." (MRE, sem data)

Fontes: MRE, sem data. Elaboração própria.

As relações com o Eixo Sul foram amplas e variadas. Abrangeram, em especial, duas vertentes - aquela dos países com os quais o Brasil atuou de forma sigilosa -, em especial China e África do Sul, e aquela dos países com os quais o Brasil atuou de forma ostensiva, em especial Iraque e México. Por meio de países do Sul global, o Brasil buscou compensar a desilusão ocorrida com o Eixo Assimétrico e obter benefícios variados para seu programa nuclear, em particular: insumos para o programa autônomo (China), cooperação tecnológica pela via horizontal (Iraque, África do Sul), mercado consumidor para a tecnologia nacional (Iraque, México) e consequente revigoramento da tecnologia de jato centrífugo (México). Tratou-se, dessa forma, de eixo abrangente, surgido com o objetivo de fortalecer a busca brasileira por tecnologia nuclear e de suprir a desilusão corrida com o Eixo Assimétrico.

\section{Conclusões Parciais}

Entre 1979 e 1789, os três eixos exerceram, cada qual, importância considerável na busca de obter tecnologia nuclear. Ao passo que o Eixo Assimétrico se mantivera

\footnotetext{
${ }^{270}$ MRE, sem data
} 
arrefecido, pautado pela crescente desilusão com os países do Norte Global, com os quais as relações se mantiveram, apenas, no âmbito das obrigações assumidas no passado, em especial com os acordos de 1974-1976 com Bonn; o Eixo Regional, com a Argentina, pautou-se pela crescente aproximação bilateral, em especial após a solução da crise das cataratas e a Guerra das Malvinas. Com a Argentina, iniciou-se parceria consistente, que já dava sinais de formação futura de medidas de instituições de confiança mútua. O terceiro eixo, o Sul, constituiu elemento característico dessa terceira fase e demonstrou que o Brasil se abria a alternativas para a consecução de se parque nuclear, tanto nas vertentes oficial quanto autônoma.

Essa divisão das relações bilaterais em três eixos, durante o período entre 1979 e 1989, com destaque par ao Eixo Sul, tornou-se possível devido aos desenvolvimentos internos brasileiros, em especial a crise econômica, a abertura política e o surgimento de novos atores a determinarem os rumos da política nuclear nacional. Esses fatores conjunturais marcaram, de forma mais impactante, o governo de José Sarney, quando a política nuclear deixou de ser conduzida de forma sistemática pela Presidência da República e quando a vertente alternativa de obtenção de tecnológica nuclear, o programa autônomo, começou a mostrar sinais de êxito. De fato, o programa paralelo representou meio relevante para a obtenção de tecnologia nuclear pelo Brasil, bem como influiu diretamente nas relações bilaterais do país, em particular no Eixo Sul, nas relações com China e Iraque.

Dessa forma, apesar de o Brasil, na década de 1980, ter apresentado opção pela via nacionalista de desenvolvimento de tecnologia nuclear, ou seja, "voltou-se para dentro", o período representou importante etapa no processo de adesão do Brasil ao regime internacional de não proliferação nuclear. Nesse período, o país consolidou a ampliação das opções brasileiras alternativas ao Eixo Assimétrico (prevalecente entre 1969 e 1978); evitou a conflagração de corrida armamentista no Cone Sul e gerou as bases para a cooperação estratégica futura com a Argentina no campo nuclear; permitiu ao Brasil universalizar suas alternativas para obtenção de energia nuclear, bem como instrumentalizar as relações bilaterais para melhor atendê-las aos objetivos definidos pelos grupos domésticos. 
Capítulo 4.

\section{A renovação de credenciais (1990-1998): a adaptação do Brasil ao regime internacional de não proliferação nuclear}

\section{Introdução}

O período entre 1990 e 1998 pode ser caracterizado como aquele mais relevante para a o processo de adaptação da política nuclear brasileira ao regime internacional de não proliferação. Isso decorre de ter sido nesse período que o Brasil, sob os governos de Fernando Collor, Itamar Franco e Fernando Henrique Cardoso, constituiu as medidas de confiança necessárias para aderir, de fato, ao regime internacional de não proliferação nuclear. Dessa forma, eliminaram-se as críticas feitas à política atômica brasileira por países do Eixo Assimétrico, em especial os Estados Unidos, e o Brasil confirmou a sua opção pela utilização da energia advinda do átomo tão somente para fins pacíficos.

No que concerne aos usos pacíficos da energia nuclear, vale salientar que a década de 1990 marcou mudança profunda na estrutura da política nuclear brasileira, que afetou tanto seu âmbito discursivo quanto sua prática, qual seja, o abandono da tese das explosões pacíficas. Esse abandono da doutrina jurídica que embasou o discurso brasileiro desde a década de 1950 e que fundamentou a constituição de parte do programa nuclear autônomo levou a processo gradual de abertura das instituições internas de controle da política ao escrutínio internacional.

Essa abertura ocorreu de forma gradual ao longo dos três governos supracitados, tendo adquirido especial relevância no governo Collor, quando foi delineada a maneira como o Brasil iria conciliar as ambições nacionais (1) de desenvolver tecnologia nuclear de maneira autóctone (herança do programa paralelo, na década de 1980), (2) de obter transferência de tecnologia do Eixo Assimétrico (retomada da década de 1970, apesar da desilusão vivenciada na década de 1980), (3) de manter sistema regional pacífico e seguro, livre de ameaças nucleares externas (para isso, a aproximação com a Argentina foi fundamental). Conciliar essas três ambições foi feito por meio da constituição de instituições capazes de criar medidas de confiança internacionalmente aceitas e efetivas.

Entre essas instituições, destacaram-se a formação da ABACC e do Tratado Quadripartite, que formaram sistema efetivo de aproximação bilateral argentino- 
brasileiro, percebido como confiável ante a comunidade internacional e o qual permitiu solidificar a cooperação estratégica ${ }^{271}$ no campo nuclear. Esse sistema materializou-se e adquiriu maior efetividade no governo Itamar Franco, o qual deu continuidade à política nuclear de seu antecessor, afastado por meio de processo de impeachment, ao manter e consolidar o arcabouço institucional conformado pela ABACC e pelo Quadripartite e ao dar aproximar ainda mais o Brasil do regime internacional de não proliferação nuclear, por intermédio da adesão incondicional, em 1994, ao Tratado de Tlatelolco, o qual, só então, passa a entrar em vigência ${ }^{272}$ (CERVO, 2009). Também em 1994, entra em vigor o INFCIRC/435 (Information Circular of the IAEA Nr. 435), o qual reedita o INFCIRC/66, de 1991, de modo a permitir à AIEA realizar salvaguardas abrangentes ${ }^{273}$ aos programas nucleares brasileiro e argentino (GUIMARÃES, 2011).

Posteriormente, no governo Cardoso, o Brasil ingressa, em definitivo, ao regime internacional de não proliferação nuclear, ao aderir ao Regime de Controle de Tecnologia de Mísseis (MTCR), em outubro de 1995, ao aderir ao Tratado de Interdição Completa de Ensaios Nucleares (CTBT), assinado em 1996 e ratificado em julho de 1998, ao tornar-se membro do GSN e ao assinar e ratificar o TNP, em 1998. Esse processo, feito em poucos anos, foi possível devido aos rumos que Cardoso deu à sua política externa, em especial no primeiro mandato, focado na aproximação com os países do Eixo Assimétrico (CERVO, BUENO, 2011) e de autonomia pela integração aos regimes internacionais vigentes (VIGEVANI et al, 2003). No campo nuclear, a adesão completa ao regime, de justificativa controversa, como se verá posteriormente, somente foi possível devido ao processo de gradual aproximação com as instituições internacionais de salvaguarda, delineado pelos antecessores imediatos de Cardoso.

\footnotetext{
${ }^{271} \mathrm{O}$ termo cooperação estratégica refere-se a uma das facetas da parceria estratégica, a qual é termos mais abrangente e que abrange outros elementos, como fluxos comerciais e de investimento e densidade de diálogo político (LESSA, 2010, apud SARAIVA, 2013). A cooperação estratégica implica alto grau de confiança e grande densidade entre dois países em determinado tema, o que suplanta a relação de cordialidade oficial, verificada, grosso modo, até governo Figueiredo, mas a qual ainda se mantém no panorama do pragmatismo, que é uma das principais características da condução das relações externas brasileiras (CERVO, 1994).

${ }^{272}$ A entrada em vigência do Tratado de Tlatelolco ocorreu apenas 1994, com a adesão simultânea da Argentina, do Brasil, do Chile e de Cuba.

${ }^{273}$ Segundo o engenheiro Leonam dos Santos Guimarães (2011), as salvaguardas abrangentes são aquelas que seguem o modelo do INFCIRC/153 e que são aplicadas a todos os países não nuclearmente armados partes do TNP. Esse modelo garante que os inspetores da AIEA tenham livre acesso a todo material fissionável detido pelos países que são partes do TNP, bem como às fontes desses materiais, "com o objetivo exclusivo de verificar que esse material não seja desviado para [produzir] armas nucleares ou outros artefatos nucleares explosivos" (AIEA, 1972: 3, tradução livre). As inspeções são realizadas de modo periódico, mediante prévio aviso da AIEA, exceto para os países partes do Protocolo Adicional ao TNP.
} 
Dessa forma, em menos de uma década, o Brasil procede à adaptação de sua política nuclear ao regime internacional de não proliferação nuclear, em meio a processo amplo, no qual cada um dos três governos realizou passos fundamentais. Entre 1990 e 1998, o Brasil torna-se membro efetiva da grande maioria das instituições que compõem o regime internacional de não proliferação nuclear ${ }^{274}$, bem como mantém seu programa nuclear de matiz autonomista e consolida relação abrangente e intensa com a Argentina. É conformado, então, sistema efetiva de prevenção à nuclearização dos países da América Latina, que se torna caso fundamental de êxito na prevenção da proliferação de armas nucleares.

Para melhor analisar esse período chave da trajetória da política nuclear brasileira e da adaptação dessa política ao regime internacional de não proliferação nuclear, o presente capítulo divide-se em cinco partes. A primeira parte traça um panorama da política nuclear brasileira entre 1990 e 1998, com destaque para as mudanças no cenário internacional e nas ações e discurso desenvolvidos pelos governos que sucederam no Palácio do Planalto. A terceira parte aborda, de maneira específica, os desenvolvimentos ocorridos no Eixo Regional, com particular destaque para a consolidação da cooperação estratégica por meio da confecção do sistema ABACC-Quadripartite. A quarta parte analisa os desenvolvimentos ocorridos no Eixo Assimétrico, com ênfase nas relações com a Alemanha, com os Estados Unidos e nos impactos e justificativas para a adesão brasileira ao TNP. Por fim, a quinta parte engloba as conclusões parciais.

\footnotetext{
274 Dos principais instrumentos relativos à não proliferação nuclear na América Latina, o único instrumento o qual o Brasil ainda não aderiu é o Protocolo Adicional ao TNP, que permite à AIEA realizar visitas não declaradas a seus países- partes e a fiscalizar não apenas as instalações em funcionamento declaradas ao TNP, mas também quaisquer outras onde seja possível desenvolver programa nuclear, como, por exemplo, centros de pesquisa, reatores desativados, usinas de energia. Esse protocolo foi criado após a Guerra do Golfo, quando se descobriu, no Iraque, a existência de instalações nucleares clandestinas, onde era conduzido programa nuclear com fins militares. O Brasil não aderiu a esse protocolo porque entende que o Quadripartite e o INFCIRC-435 já oferecem medidas equivalentes àquelas do Protocolo adicional. A posição brasileira foi reconhecida oficialmente pelo GSN.
} 


\section{A política nuclear e os novos paradigmas da inserção internacional do Brasil $^{275}$}

A década de 1990 foi marcada por otimismo inicial, pautado pela difusão de conferências relativas a novos temas e pela ampliação de estudos relativos à governança global. Foram desenvolvidas novas abordagens para analisar a interdependência entre as nações ao redor do globo, que agora passava a ser visto como uma global village (BHAVNAGRI, 2001). Nesse contexto, o holocausto nuclear passou a ser tratado como risco cada vez menos provável (BRENNER, 2009) e a comunidade internacional, em especial os cinco países nuclearizados legalmente reconhecidos ${ }^{276}$, intentaram revigorar a AIEA e seu sistema de salvaguardas, por meio do Protocolo Adicional ao TNP, de 1997, o qual prevê maior amplitude às atividades de salvaguardas da AIEA.

Além disso, mudanças sistêmicas na ordem internacional, como o processo de transição de poder do Atlântico rumo ao Pacífico (NYE, 2011) e a emergência de novos atores (e.g. a sociedade civil) e de novos temas (SATO, 2000) ao centro do sistema internacional trouxeram, novamente, as armas nucleares e o uso da energia atômica para fins energéticos ao centro da agenda global. Embora houvessem vozes que defendam o uso da matriz energética nuclear, porquanto ela é limpa (TBI, 2015), verificam-se na sociedade civil fortes posições contrárias a qualquer uso de tecnologia atômica ${ }^{277}$. Isso se deveria tanto à contínua ocorrência de acidentes nucleares ${ }^{278}$ quanto ao poder destrutivo dessa tecnologia, caso utilizado para fins bélicos.

Esse movimento, instigado por setores da academia, por partidos políticos, como o Partido Verde alemão, e por ONGs ambientais, como o Greenpeace, contrários a testes nucleares justifica-se não pela capacidade destrutiva dos armamentos, mas pelo impacto

\footnotetext{
${ }^{275}$ Segundo conceito do professor Amado Cervo (2009), confirmado em palestra realizada em 26 de maio de 2015, Inserção Internacional é termo que se refere à convergência de três variáveis na movimentação internacional de um país: (1) a ação diplomática; (2) a política exterior; (3) o movimento dos agentes sociais [internos]. A partir desse conceito, Cervo (2009) desenvolve quatro paradigmas para a inserção internacional do Brasil, em perspectiva histórica: (1) o Estado liberal (1822-1929); (2) o Estado Desenvolvimentista (1930-1990); o Estado Normal (1990-2002); o Estado Logístico (2003 -), modelo que entrou em declínio a partir do governo Rousseff (CERVO; LESSA, 2014).

${ }^{276}$ São esses países aqueles que obtiveram armas nucleares antes da criação do TNP, em 1967. São eles: Estados Unidos, União Soviética (após 1992, Rússia), Reino Unido, França, China.

277 Exemplo desses posicionamentos são o protesto da ONG Greenpeace contra testes nucleares ocorridos, principalmente, a partir da década de 1990, o que Arquilla e Ronfeldt (2001) enquadraram em meio ao conceito de guerra de redes (netwar).

${ }^{278}$ Entre os acidentes nucleares ocorridos no pós Guerra Fria, destacam-se Seversk (1993), na Rússia, e em Tokaimura (1999) e Fukushima (2011)
} 
ambiental desses testes, em especial das ogivas de segunda e de terceira geração ${ }^{279}$. Essa questão ambiental influenciará, principalmente, o governo Collor, que transformará o meio ambiente e uma das principais marcas de sua política externa (SALLUM JR, 2011), especialmente ao defender a tese de que os países em desenvolvimento precisariam "ter acesso facilitado às tecnologias que permitem eliminar os danos ao meio ambiente e que se apresentam como ecologicamente seguras" (COLLOR, 24 set. 1990). Entre essas tecnologias, destacar-se-á a energia nuclear, apesar de essa ser alvo de críticas cada vez maiores de grupos sociedade civil emergentes desde fins do regime militar $^{280}$ e, em especial, no Brasil, após o acidente radiológico de Goiânia ${ }^{281}$.

No âmbito interestatal, por sua vez, a proliferação de armas nucleares continuou na pauta internacional, em particular devido ao perigo de escalada nuclear em regiões como o Oriente Médio (COOK, 2012), onde se descobriu, na Guerra do Golfo, centrais nucleares clandestinas mantidas pelo governo Saddam Hussein ${ }^{282}$. A Guerra do Golfo, por si só, significou a proclamação de mudanças significativas entre a ordem internacional pós-Guerra Fria e aquela que a precedeu. A nova ordem "residiria no binômio político-econômico da democracia (neo)liberal, considerada o último estágio da evolução do espírito [humano]", além do que o fim da disputa bipolar entre Estados Unidos e União Soviética deveria levar à aproximação daquele com o "países do Terceiro Mundo", na forma de estreitamento dos laços diplomáticos e doa aumento de investimentos externos diretos (ARRAES, 2004: 113).

Apesar dessa euforia, seria mantido o elevado gasto bélico, no caso dos Estados Unidos, ilustrado pela própria participação na Guerra do Golfo, na década de 1990.

\footnotetext{
${ }^{279}$ Exemplo desse grande impacto pode ser dado pelo Atol de Bikini, cuja fauna e flora marinha ainda não se recuperaram, completamente, dos impactos causados pelos testes nucleares americanas nas décadas de 1940 e de 1950.

280 "The more liberal environment has also facilitated the organization of small antinuclear groups, consisting mainly of civilian scientists and environmental protectionists, who would like to see Brazil's nuclear program terminated" (CIA, 21 out. 1983).

${ }^{281} \mathrm{O}$ acidente radiológico de Goiânia foi um episódio de contaminação por radioatividade ocorrido em 13 de setembro de 1987, quando um aparelho utilizado em radioterapias foi encontrado e desmontado por catadores de lixo e, posteriormente, repassados a terceiros. Esse acidente, que envolveu a transmissão por Césio-137, pode ser considerado o maior acidente nuclear da história ocorrido fora de usinas nucleares (G1, 19 set. 2012).

${ }^{282}$ Sobre esse ponto, vale lembrar que, apesar de o Brasil, como demonstrado no capítulo anterior, ter colaborado intensamente com o desenvolvimento do programa nuclear iraquiano na década de 1980, Brasília se afastou consideravelmente de Bagdá na década de 1990, devido à diversificação das parcerias de petróleo, do maio $\mathrm{r}$ número de fornecedores disponíveis no mercado internacional e de mudanças sistêmicas ocasionadas pelo fim da Guerra Fria. Nesse contexto, Collor e seu chanceler, Francisco Resek, buscaram afastar-se dos "alinhamentos automáticos" com os países fornecedores de petróleo e mantiveram incentivos à produção nacional de petróleo (FARES, 2007).
} 
Com Clinton, o foco da política externa e interna americanas voltar-se-ia à esfera econômica (ARRAES, 2004; PECEQUILO, 2005), com a confiança no fim de ameaças possíveis e com a ênfase na globalização econômica e política e nos seus possíveis efeitos positivos sobre a comunidade internacional. Essa ênfase no papel crucial da globalização foi compartilhada por Fernando Henrique Cardoso, que adaptou da sociologia política o conceito de globalização assimétrica, segundo o qual os enormes benefícios políticos e econômicos da globalização, como o aumento da riqueza e o acesso a novas tecnologias, não se difundiam de forma equivalente pelo globo - ao contrário, afirmava Cardoso, em linha semelhante àquela da teoria da dependência, que havia assimetria entre os países desenvolvidos e os periféricos na obtenção daqueles benefícios (SILVA, 2008).

Essas consideráveis mudanças na ordem internacional influiriam de modo significativo os rumos dos governos brasileiros entre 1990 e 1998. Nesse período, o Brasil passaria, sequencialmente, de governos que se identificavam com o otimismo liberal e com as promessas de paz e prosperidade oriundos do fim da Guerra Fria (governo Collor) e que já analisavam as relações com o Norte Global com certas ressalvas, especialmente no que concerne à possibilidade de obter tecnologia (governos Franco e Cardoso). Esse período final da década de 1990 também viu surgir a promessa de maior interconectividade entre as economias mundiais, em especial pelo projeto da Área de Livre Comércio das Américas (ALCA), que levou a abrangente impacto na opinião pública brasileira e que cujo possível firmamento teria motivado a assinatura do TNP pelo governo Cardoso (MONIZ BANDEIRA, 2004).

Esse contexto global em transformação afetou, também, os desenvolvimentos internos que vinham ocorrendo no Brasil. Verificaram-se modificações na política externa se coadunavam com mudanças internas nos planos econômico (a crise que sucedeu o crescimento acelerado dos governos militares), político (consolidação do processo de redemocratização), ideológica (liberalismo) ${ }^{283}$. Diferentemente do governo Sarney, que manteve as diretrizes externas universalistas e o desenvolvimentismo oriundo dos governos militares, em especial a partir da administração Geisel (CÔRTES, 2010; VIZENTINI, 1998; CERVO, BUENO, 2010), os governos Collor, Franco e Cardoso modificaram os paradigmas de inserção internacional do Brasil, de modo a

${ }^{283}$ CARDOSO, 31 mar. 1993 
colocar o país em consonância com o ideário liberal globalmente em voga. A essa forma de inserção internacional, que marcou, em especial, o governo Collor, Amado Cervo (2009) denomina, criticamente, de Estado Normal, ao passo que Brasílio Sallum Júnior (2011), em análise mais positiva, cognomina de integração competitiva, porquanto teria como objetivo primordial transferir o dinamismo da economia nacional do Estado para a iniciativa privada.

Em Collor, acreditava-se que a abertura econômica do país e a sua "adaptação ao 'novo momentum internacional'" (HIRST, PINHEIRO, 1995: 6) instariam melhora nas "condições de acesso a mercados, créditos e tecnologia" (AZAMBUJA, 1991, apud HIRST,PINHEIRO, 1995:7). Isso ensejaria postura mais propositiva do Brasil no cenário internacional, o que seria possível devido à legitimidade inicial conferida ao presidente pelas primeiras eleições diretas ocorridas em mais de vinte anos (HUNTER, 1997). Essa legitimidade permitiu a Collor, nos momentos iniciais do seu governo, maior margem de manobra para reavaliar a postura do "nacionalismo de fins" que permeou a política externa brasileira até fins da década de 1980 (LAFER, 2004: 88) e para modificar, dessa forma, a postura brasileira em relação a temas sensíveis de interesse militar desde a década de 1960, como era o caso da política nuclear - a qual pouco havia sido modificada pelo governo Sarney.

A modificação da política nuclear brasileira em Collor também se coadunava com a modificação dos rumos externos do Brasil e com a mencionada adaptação à nova realidade internacional, de modo a aproveitar as oportunidades decorrentes do fim da Guerra Fria e do novo cenário de euforia em andamento. A nova política nuclear fora concebida em meio a ampla modificação das relações internacionais do Brasil, no qual a política externa, em sentido amplo, seria caracterizada pelo fim previsto do nacionalismo, pela modernização da economia (aspecto discursivo fundamental), a promessa de universalismo e megablocos (em particular após o colapso do socialismo soviético) e o retorno das teses liberais (CERVO, 1994).

Nesse contexto, fazia-se necessário que a nova política nuclear fosse "mais flexível vis-à-vis [os] regimes de não-proliferação; e, no âmbito interno, restringi[sse] a participação dos militares na condução da política nuclear" (HIRST, PINHEIRO, 1995: 6). Nesse sentido, além da assinatura do Mercado Comum do Sul (MERCOSUL) no plano econômico, uma das maiores sinalizações da nova inserção internacional do 
Brasil, bem como das "confidence building measures destinadas a reduzir as tensões na área estratégico-militar" com a Argentina (LAFER, 2004: 59), foi a formação da ABACC e do Quadripartite (HIRST, PINHEIRO, 1995). Essas instituições incluíram em seus arcabouços normativos o "compromisso de não-realização de explosivos nucleares, ainda que para fins pacíficos" e que resguardaram "as pesquisas nucleares que a Marinha brasileira fazia sobre propulsão de submarinos" (SALLUM JR, 2011:271) e, além disso, essas instituições permitiriam ao Brasil e à Argentina ingressar no regime internacional de não proliferação nuclear sem abandonar as críticas feitas à injusta “divisão internacional de poder" (COLLOR, 24 set. 1990), encarnada pelo TNP.

Apesar dessa ressalva feita às pesquisas da Marinha, o antigo Projeto Remo, foi no governo Collor que o programa nuclear autônomo foi definitivamente desativado, mediante cerimônia pública realizada em setembro de 1990, quando o presidente jogou uma pá de cal no campo de testes para possíveis "explosões pacíficas" da Aeronáutica na Serra do Cachimbo (PATTI, 2014: 6). Essa desativação representou o abandono definitivo da tese das explosões pacíficas, substituída pela afirmação, defendida desde a década de 1960 por países como o México (DAWOOD, HERZ, 2013), de que todas as explosões nucleares tinham fins militares, porquanto não existiria maneira clara e objetiva de se diferenciar explosivos bélicos dos supostos explosivos pacíficos. Além disso, a pá de cal representou o controle definitivo pelo poder civil das instituições nucleares brasileiras (VELÁZQUEZ, 2004), representado por lideranças políticas civis no Congresso e no governo e pela designação de membros civis da comunidade científica para os principais órgãos internos responsáveis pela condução da política nuclear (WROBEL, REDRICK, 1998).

Após o impeachment, Itamar Franco manterá e ampliará o processo de adaptação da política externa e nuclear brasileira ao novo momentum internacional, porém de maneira menos intensa do que Collor, devido ao "contexto doméstico e internacional notavelmente desfavorável ao Brasil" (HIRST, PINHEIRO, 1995:10), o qual pouca oportunidade deu a Franco de dedicar-se a assuntos externos. Diferentemente de Collor, que tinha como objetivo retórico e prático inserir o Brasil no Primeiro Mundo, Franco retomou "posicionamento marcado pela condição de país em desenvolvimento" (HIRST, PINHEIRO, 1998: 11), o que implicou tom mais reivindicatório na política externa. De fato, Franco, assim como fará Cardoso, retomou os contatos privilegiados 
com coalizões de países do Sul Global, em especial latino-americanos, e afirmou que os compromissos assumidos no campo da não proliferação nuclear, autorizavam os países do Sul Global a exigir acesso desimpedido a tecnologias de ponta ${ }^{284}$.

Esse novo tom da política externa afetaria a política nuclear, na medida em que, além de complementar o complexo sistema de salvaguardas e de construção de confianças com a Argentina, Franco ampliou o escopo dos procedimentos que vinham ocorrendo no campo nuclear de modo a abarcar, também, a completa adesão do Brasil, em conjunto com Argentina e Chile, ao Tratado de Tlatelolco. Essa proposta de adesão era consequência natural da concretização da parceria estratégica com a Argentina, cujo programa nuclear instava temor nos governos brasileiros (CASTRO NEVES, 2012, apud MALLEA at al, 2015:176) de mudança do equilíbrio geopolítico regional ${ }^{285}$, e já vinha sendo tratada desde a gestão Alfonsín na Casa Rosada. Tlatelolco também permitiu ao Brasil e à Argentina ingressarem em um sistema abrangente e multilateral (DAWOOD, HERZ, 2013), o que deveria produzir efeitos semelhantes a uma possível adesão futura ao TNP.

Cardoso, que substitui Franco no Palácio do Planalto, consolidou o poder de ingerência dos civis na política nuclear, com a criação do Ministério da Defesa, o qual abarcará a Marinha. Esse processo foi considerado fundamental para a consolidação completa do processo de redemocratização e de retirada do poder de influência dos militares na política (HUNTER, 1997; O’DONNELL, 1988). No plano externo, Cardoso realizou política externa que manteve certas diretrizes daquela de Franco, de quem fora chanceler, como a manutenção concomitante de discurso liberal e de aproximação com países em desenvolvimento, em especial na América Latina. Cardoso desenvolveu inserção internacional e política externa de aproximação dos regimes internacionais vigentes, de modo a ampliar a margem de manobra do país e de possibilitar acesso aos benefícios que, ele entendia, podiam ser obtidos da globalização.

\footnotetext{
${ }^{284}$ Segundo discurso do presidente, "ao assumir compromissos firmes e inequívocos no campo da nãoproliferação e do desarmamento, o Brasil - como os demais países latino-americanos — sente-se autorizado a exigir dos seus parceiros mais desenvolvidos o acesso desimpedido, mesmo que em bases comerciais, às tecnologias de ponta. $\mathrm{Na}$ sua essência, o desenvolvimento econômico é um processo de difusão do progresso técnico. Por isso, na agenda da próxima reunião presidencial do Grupo do Rio, propomos que o tema «Ciência e Tecnologia» seja privilegiado, especialmente no que tange a acesso a tecnologias sensíveis" (FRANCO, 15 out. 1993).

${ }^{285}$ Para uma melhor análise do impacto do programa argentino na política nuclear brasileira, em especial na década de 1980, vide capítulo anterior.
} 
Pode-se denominar a essa estratégia de inserção global autonomia pela integração (VIGEVANI et al: 2003).

No campo atômico, Cardoso empreendeu abrangente de consolidação da integração do Brasil no regime internacional de não proliferação nuclear. O primeiro passo nessa direção foi a adesão ao MTCR, em outubro de 1995 (BOWEN, 1996). Embora o MTCR constitua instituição internacional com pouca relação direta com o TNP ou com a AIEA, ele pode ser considerado como instituição internacional diretamente relacionada à não proliferação de armas nucleares, porquanto trata de mísseis balísticos de foguetes, os quais são os vetores comumente utilizados para a entrega de bombas atômicas. Além disso, como lembra Wyn Bowen (1996), a posição brasileira com relação ao MTCR acompanhou, historicamente, os desenvolvimentos da política nuclear brasileira, inclusive na década de 1980, quando o desenvolvimento de mísseis nucleares foi aventado como objetivo posterior do programa nuclear autônomo - mais especificamente, no Projeto Solimões ${ }^{286}$, e com cronograma possível para possíveis testes na Serra do Cachimbo ${ }^{287}$. Além disso, a concomitante busca argentina pelo desenvolvimento de mísseis balísticos de médio alcance (Condor-2) também teria influenciado a posição brasileira contrária ao MTCR, de modo que a participação efetiva do Brasil nesse regime somente se concretizou depois de constituída a cooperação estratégica no campo nuclear, nos dois governos anteriores, e depois de Buenos Aires ter aderido àquele regime, em 1993.

Cardoso também assinou, em 1996, o Tratado de Interdição Completa de Ensaios Nucleares (CTBT), ratificado em 1998 pelo Congresso brasileiro. Apesar de ainda não estar vigente $^{288}$, a assinatura do CTBT, concomitantemente com a Argentina quando da confecção do tratado (ambos são membros iniciais), representou consolidação da posição brasileira favorável de inserção no regime internacional de não proliferação e

\footnotetext{
${ }^{286}$ FOLHA, 8 aug. 1986.

${ }^{287}$ Vale lembrar que, segundo reportagem da Folha de São Paulo (8 aug. 1986), a base aérea da Serra do Cachimbo já era utilizada, em meados da década de 1980, para testes de materiais nucleares, como bombas de fragmentação e mísseis convencionais, ambas tecnologias restringidas pelo MTCR

${ }^{288}$ O CTBT deverá entrar em vigor 180 dias após sua ratificação pelos 44 Estados listados no Anexo 2. Esses Estados são aqueles que participaram das negociações, entre 1994 e 1996 e que, naquele período, possuíam reatores nucleares de pesquisa. Atualmente (maio de 2016) ainda faltam, entre os países membros do Anexo 2, ratificar o CTBT: China (assinou em 24 de setembro de 1996); República Democrática da Coreia (não assinou); Egito (assinou em 14 de outubro de 1996); Índia (não assinou); Irã (assinou em 24 de setembro de 1996); Israel (assinou em 25 de outubro de 1996); Paquistão (não assinou); Estados Unidos (assinou em 24 de setembro de 1996). Dados disponíveis em: <https://www.ctbto.org/the-treaty/status-of-signature-and-ratification/>, acessado em 03/05/2016.
} 
confirmou o abandono da tese jurídica das explosões pacíficas, porquanto esse tratado, no artigo primeiro, proíbe categoricamente os Estados-membros a realizarem explosões nucleares de qualquer natureza ${ }^{289}$. Assim, a assinatura de instrumento jurídico com essa linguagem somente foi possível devido à modificação da política nuclear brasileira.

Outro elemento relevante levado a cabo pelo governo Cardoso foi a adesão do Brasil ao GSN, em 1996. Essa adesão foi outro elemento que confirmou a mudança de rumos da política nuclear brasileira no período da consolidação da democracia (década de 1990) em relação àquela política dos governos militares. Isso porque, como explorados nos capítulos anteriores, o GSN constituiu, em especial na década de 1970, um dos principais instrumentos utilizados pelos Estados Unidos para coibir o acesso de tecnologia atômica a países do Sul Global, como o Brasil. Essa pressão foi relevante elemento para empurrar o Brasil na direção do desenvolvimento de tecnologia nuclear pela via nacionalista e pela cooperação com países do Eixo Sul, entre 1979 e 1989.

Ao entrar no GSN, o Brasil passou a ser parte da instituição multilateral que foi criada com o objetivo de controlar o acesso da tecnologia nuclear a países possivelmente proliferadores de armas nucleares. Isso consolidou o ingresso do Brasil no regime de não proliferação nuclear, porquanto se tratou do reconhecimento pelos principais países partes do Regime Internacional de não proliferação nuclear ${ }^{290}$ das credenciais de que o Brasil era país confiável defensor do "princípio da não

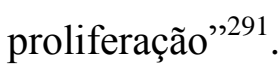

O último passo na adaptação completa do Brasil ao regime internacional de não proliferação nuclear foi a adesão ao TNP, assinado em de julho de 1998 e ratificado em 18 de setembro do mesmo ano. Essa decisão, quando da assinatura do tratado, em 1998,

\footnotetext{
289 “Article I. Basic Obligations. 1. Each State Party undertakes not to carry out any nuclear weapon test explosion or any other nuclear explosion, and to prohibit and prevent any such nuclear explosion at any place under its jurisdiction or control. 2. Each State Party undertakes, furthermore, to refrain from causing, encouraging, or in any way participating in the carrying out of any nuclear weapon test explosion or any other nuclear explosion" (UNGA, 1996).

${ }_{200}$ Na década de 1990, o NSG passa a englobar todos os cinco países nuclearizados aceitos pelo TNP, com a inclusão de China e Rússia.

291 "The NSG Guidelines also contain the so-called "Non-Proliferation Principle," adopted in 1994, whereby a supplier, notwithstanding other provisions in the NSG Guidelines, authorises a transfer only when satisfied that the transfer would not contribute to the proliferation of nuclear weapons. The NonProliferation Principle seeks to cover the rare but important cases where adherence to the NPT or to a Nuclear Weapon Free Zone Treaty may not by itself be a guarantee that a State will consistently share the objectives of the Treaty or that it will remain in compliance with its Treaty obligations." (Descrição oficial dos princípios do NSG. Disponível em: <http://www.nuclearsuppliersgroup.org/en/about-us> , acessado em 03/05/2016.
} 
já era "matéria de consenso",292 entre os integrantes do governo Cardoso, em especial no MRE e na Presidência da República, e coadunava-se com os desenvolvimentos anteriores de afastamento da política nuclear dos militares ${ }^{293}$ e definição de nova estratégia de inserção internacional por novos grupos de poder, como exposto no capítulo 1.

De fato, com a adesão do Brasil a grande arcabouço institucional que coibia o desenvolvimento de armas nucleares, nos governos Collor e Franco, a necessidade de manter-se fora do TNP tornava-se inócua ${ }^{294}$, porquanto já se tinha desenvolvido, na prática, medidas de confiança suficientes que garantissem que o Brasil não obteria armas de destruição massiva. Apesar disso, como lembra Celso Lafer (2004), o governo Cardoso entendia a revelia brasileira em aderir ao TNP como pouco coerente com as pretensões brasileiras de se firmar como um protagonista no regime internacional de não proliferação. Essa posição seria, também, confirmada pelos países com os quais o Brasil passara a compartilhar o repúdio ao TNP, qual sejam, Cuba e os "três países não previstos no Tratado na categoria de Estados nuclearmente armados, porém detentores de fato de capacidade nuclear com finalidade militar, quer explicitamente admitida (Índia e Paquistão), quer deliberadamente omitida (Israel)" (LAFER, 2004: 61).

Feitas essa explanações iniciais sobre as mudanças na ordem internacional na década de 1990 e sobre o processo de gradual e constante adaptação da política nuclear brasileira ao regime internacional de não proliferação nuclear nos governos Collor, Franco e Cardoso, parte-se para análise específica dos Eixos Bilaterais da política

\footnotetext{
${ }^{292}$ LAMPREIA ( $2^{\mathrm{a}}$ entrevista. 29 jan. 2008: 41)

293 Segundo Luiz Lampreia (2 $2^{\text {a }}$ Entrevista. 29 jan. 2008:77), “.A credencial de ter uma indústria nuclear era muito importante, mas eu nunca achei que o Brasil devia ter uma bomba, não é? Eu achei sempre ao contrário, que o Brasil devia ser opositor desse curso, porque isso justamente significaria, digamos, um desvio do Brasil para um caminho alternativo como aquele daquela discussão anterior, de Genebra, do neutralismo, do terceiro-mundismo e tudo mais, sem razão nenhuma. [...] O Brasil, para fazer um programa nuclear, teria que desviar muitos bilhões de dólares de carências enormes que tem com a sua população, de educação, de saúde, de habitação, de coisas fundamentais, para fazer bomba?! [...] Quer dizer, a ameaça argentina é uma coisa mental, não é? Não havia uma coisa real. [...] Tanto que você vê que o que faz a abertura para a Argentina e, especificamente, a anulação no caminho nuclear com a Argentina é a coincidência com a redemocratização, com o fim do regime militar no Brasil, é evidente, que foi o que permitiu que acontecesse isso".

294، [a resistência à adesão ao TNP] já tinha praticamente acabado, porque claramente o presidente [ Cardoso] não estava nessa linha, não é? E também porque na Constituição de 88; depois, no acordo com a OEA... Com a AIEA; depois, com os acordos com a Argentina, bilaterais, a criação da Abacc e os acordos bilaterais; e a adesão plena ao Protocolo de Tlatelolco, o Brasil já tinha praticamente se comprometido totalmente a não ter armas nucleares, não é? Não havia mais o que discutir. (LAMPREIA, $2^{a}$ entrevista. 29 jan. 2008: 78)
} 
nuclear brasileira. Essa análise será realizada em duas partes, a primeira constando do processo de gradual afastamento do estabelecimento de cooperação estratégica no Eixo Regional. Nessa parte, focar-se-á nos processos de conformação da ABACC e do Quadripartite. Posteriormente, em uma segunda parte, analisar-se-ão as relações com o Eixo Assimétrico, com ênfase nas consequências da adesão brasileira ao TNP ${ }^{295}$.

No que concerne ao Eixo Sul, o qual foi obteve considerável relevância no período anterior, em especial no governo Figueiredo, tornou-se progressivamente menos proeminente no decorrer da década de 1990. Essa menor proeminência ocorreu de forma concomitante com o afastamento gradual dos países do Sul Global pela política externa brasileira, o que ocorreu simultaneamente à liberalização da economia e do discurso sobre política externa ocorrido já ao final do governo Sarney (CASARÕES, 2012). No campo nuclear, a ênfase dos governos que sucederam no Palácio do Planalto na década de 1990 foi a da transparência na condução do programa atômico, o que se demonstrou pouco coerente com a manutenção do Eixo Sul, o qual tinha como uma de suas principais características obter insumos para desenvolver tecnologia nuclear para fins múltiplos de maneira autóctone. Exceção pode ser feita, porém, à aproximação com o México, com o qual o Brasil, como se verá a seguir, deu indicativos favoráveis de aproximação, em especial ao firmar, com a Argentina, o acordo constitutivo da ABACC na cidade de Guadalajara.

\section{A institucionalização da Cooperação Estratégica no campo nuclear: o Eixo Regional, a ABACC, o Quadripartite}

Entre 1990 e 1998, o eixo que aqui se considera mais dinâmico das relações bilaterais da política nuclear brasileira foi o Eixo Regional, que contém as relações com a Argentina, principal ator da América do Sul a influir na definição da política brasileira para o campo atômico. Nesse período, consolidou-se a aproximação institucional entre ambos os países em âmbito multitemático e abrangente, o qual incluiu, principalmente, os campos econômico-político - com o Mercosul - e de segurança - ABACC-

\footnotetext{
${ }^{295}$ A escolha de explorar a ABACC, o Quadripartite e a adesão ao TNP decorrem da consideração aqui feita de que esses foram os principais fatores a afetarem a política nuclear brasileira na década de 1990. Isso ocorre porque, apesar de importantes, a adesão brasileira ao GSN e ao MTCR não geraram impactos consideráveis imediatos na movimentação internacional do Brasil no campo atômico, ao passo que a adesão a Tlatelolco era percebido como consequência natural do Quadripartite, da aproximação com a Argentina e do abandono da tese das explosões pacificas.
} 
Quadripartite. Dessa aproximação decorreu a integração de ambos os países nos regimes internacionais mais amplos, dentre os quais o de não proliferação nuclear.

Essa aproximação ocorreu em meio a processo conhecido como renovação de credenciais (CERVO, BUENO 2011; FONSECA JR, 1998; SALLUM JR, 2011), segundo termos do presidente Collor. A aproximação com a Argentina incluía-se na estratégia de integração competitiva (SALLUM JR, 2011) de Collor, a qual via nas relações bilaterais argentino-brasileiras e na conformação de cooperação estratégica instrumento para o Brasil ingressar, de modo efetivo e sem riscos à segurança nacional, à comunidade internacional de modo proativo. Esse ingresso foi possível devido a características já citadas, como a efetiva prevalência de civis na administração pública.

Esse pano de fundo permitiu ao Brasil implementar política compreensiva no campo nuclear. Essa política teve duas vertentes principais - a doméstica e a externa, esta focada na aproximação com a Argentina e na integração conjunta dos dois países no regime internacional de não proliferação nuclear. Aquela, a vertente interna, buscou promover novas formas de entender a gestão da energia nuclear em meio ao Estado brasileiro. Acolá do já citado desmantelamento do programa nuclear paralelo, o qual, porém, não deixou de reconhecer os benefícios tecnológicos que esse trouxera ao país, em especial no caso do Projeto Atlântico ${ }^{296}$, o redirecionamento da política nuclear doméstica passou pela transferência do poder decisório aos civis, o que será consolidado no governo Cardoso, com a criação do Ministério da Defesa, e pela frustrada tentativa de criação de código de ética nuclear ${ }^{297}$, o qual inviabilizasse tanto a proliferação de armas nucleares pelo Brasil quanto a ocorrência de acidentes como o de Goiânia.

De modo semelhante ao Brasil, a Argentina passava por processo de redefinição de sua composição política interna, sob o governo de Carlos Menem, o qual praticou tanto política de desenvolvimento econômico baseado na aproximação irrestrita com o Norte Global - aquilo que Cervo (1994; 2009) denominou paradigma do Estado Normal, utilizando-se de termos desenvolvidos pelo Ministro da Economia, Domingo Cavallo quanto política externa de afirmação nacional. Essa política de inserção internacional,

\footnotetext{
296 “A Politica de Ciência e Tecnologia das Forças Armadas foi objeto de proposta, elaborada em conjunto com o Exército, a Marinha e a Aeronáutica, estabelecendo critérios, procedimentos e objetivos para as atividades de pesquisa e desenvolvimento cientifico e tecnológico, formação de recursos humanos e fomento industrial. (...) No Projeto de Desenvolvimento Cientifico e Tecnológico, o Exército conseguiu atingir o domínio da tecnologia de obtenção do grafite nuclearmente puro." (COLLOR, 1992: 46)

${ }^{297}$ COLLOR, 1992:27
} 
baseada, na aplicação inconstante (SCHENONI, ESCUDÉ, 2016) da teoria do realismo periférico $^{298}$, de Carlos Escudé pelo Ministro das Relações Exteriores argentino, Guido di Tella, levaram Buenos Aires a afastar-se do Movimento dos Não Alinhados, aproximar-se dos Estados Unidos, da Inglaterra e firmar "compromisso total" (SCHENONI, ESCUDÉ, 2016:10) com a não proliferação nuclear.

De fato, diversamente do caso brasileiro, no qual as forças militares e civis confluíram para uma transição gradual e negociada para o regime democrático, na Argentina, verificou-se o total colapso do regime militar, após a intempestiva Guerra das Malvinas (ROMERO, 2002; ESCUDÉ, 2005). Desse colapso, os governos civis de Raúl Alfonsín e de Carlos Menem, que sucederam, imediatamente, aos militares, tinham entre suas prerrogativas afastar a Argentina da memória dos tempos da ditadura. Isso deveria incluir transformar um "estado potencialmente perigoso" (ESCUDÉ, 2005: 77, tradução própria) em sócio confiável da comunidade internacional e em parceiro de seu principal vizinho, o Brasil, no campo da segurança internacional. Essa política de rápida adesão ao regime internacional de não proliferação nuclear, com a quase concomitante adesão ao Quadripartite, a Tlatelolco e ao $\mathrm{TNP}^{299}$ pelo governo Menem, buscou, no âmbito interno, reduzir o poder dos militares, retirando-lhes influência na condução dos rumos do desenvolvimento de uma tecnologia considerada chave para a defesa nacional, reduzir os encargos pagos pelo povo argentino à manutenção do programa nuclear, reduzir os danos que o afastamento progressivo da comunidade internacional causara aos cidadãos argentinos ${ }^{300}$.

\footnotetext{
${ }^{298}$ O Realismo Periférico tratou-se de uma teoria de relações internacionais desenvolvida por Carlos Escudé no início dos anos 1990, a qual se funda sobre premissas como a hierarquia do sistema internacional, devido ao grande diferencial de poder entre as potências, e como a categorização do desenvolvimento como o principal interesse nacional dos países periféricos (SCHENONI, ESCUDÉ, 2016). Essa teoria chamou a atenção para a relação de crescimento inversamente proporcional entre o nível de autonomia das políticas externas de países periféricos e o bem-estar de seus cidadãos e sugere aos países periféricos que, a exemplo de países como Alemanha e Japão, implementem políticas de ingresso nos regimes internacionais globais, o que levaria ao desenvolvimento econômico e ao bem-estar dos cidadãos.

${ }^{299}$ Diferentemente do governo Alfonsín, que informou previamente Sarney sobre a obtenção argentina de tecnologia para enriquecimento de urânio, Menem não informou ao Brasil da adesão argentina ao TNP. Essa falta de informação prévia foi vista com desconforto pela diplomacia brasileira e consta de um obstáculo que foi rapidamente superado por ambos os países em seu processo de aproximação.

300 "La Argentina acompañó su alineamiento con Occidente con un desarme unilateral que tiene pocos precedentes en la historia de las relaciones internacionales. Este desarme coincidía con la necesidad de eliminar empresas estatales deficitarias y con la convicción (principalmente de parte del equipo de Guido Di Tella) de que las políticas exteriores y de seguridad debían estar al servicio del ciudadano y no de un Estado cuyo poder suele convertirse en un fin en sí mismo. Este fue el sentido del llamado
} 
No início da década de 1990 verificaram-se, então, condições propícias para a instituição de aproximação bilateral efetiva entre Brasil e Argentina no campo nuclear. Essas condições foram caracterizadas pela ascensão de governantes de pensamento político-econômico similar nas Presidências da Republica de ambos os países, os também tinham igual disposição de inserir seus países nos regimes internacionais vigentes e, assim, adequar seus países ao novo contexto internacional pós-Guerra Fria. Enquanto, no campo econômico, essa aproximação deu-se com a formação do Mercosul, fundado sob o modelo do "regionalismo aberto" liberal (GARDINI, 2015:210-211), no campo nuclear, ela deu-se com a criação do arcabouço bilateral conformado pela ABACC e pelo Quadripartite, estabelecidos pelos presidentes Collor e Menem em julho e em dezembro de 1991, na cidade de Guadalajara, no México, e em Viena, respectivamente.

A própria opção por assinar instrumento de tal magnitude, o Tratado de Guadalajara, em solo mexicano possui importância simbólica, porquanto o México é país cuja postura no campo da não proliferação nuclear foi fortemente oposta àquela do Brasil e da Argentina. Isso demonstrou o interesse de Brasília e de Buenos Aires de aproximarse do regime internacional de não proliferação nuclear, em especial de sua vertente regional - o sistema Tlatelolco-OPANAL. De fato, a OPANAL apenas se tornou operativa após a adesão completa, sem ressalvas, da Argentina, do Brasil e do Chile ao Tratado, porquanto eram esses os principais países a deter políticas nucleares ativas na América do Sul (DAWOOD, HERZ, 2013; CARASALES, 16 mai. 1996).

Em 1991, conformou-se amplo sistema, o qual se pretendia ser substituto à adesão de ambos os países, Brasil e Argentina, ao TNP, porquanto permitiria a ambos os países fornecerem à comunidade internacional garantias similares àquelas dispostas por esse tratado $^{301}$. Esse sistema foi concebido sob dois pilares, os quais garantiriam à comunidade internacional que Brasil e Argentina eram países comprometidos com a não proliferação de armas nucleares, bem como com a manutenção da paz e da segurança globais, portanto se diferenciavam, substancialmente, da díade Índia-Paquistão, que

\footnotetext{
“realismo periférico" y de su carácter eminentemente ciudadanocéntrico”, tal como se plasmó en numerosas publicaciones". (ESCUDÉ, 2005: 82)

301 "The Guadalajara Agreement was viewed by many people as a substitute to the NPT, as the countries assumed commitments under this Treaty without agreeing with items in the document considered, at that time as discriminatory. In fact, the set of agreements signed could even be considered as more stringent than the NPT. The fact was that, subsequently, both countries - Argentina first and then Brazil - adhered to the NPT" (ALVIM, 2000).
} 
realizaram testes nucleares na década de 1970 e que seriam, posteriormente, classificados como Estados párea, pelos chanceleres de um grupo de trezes países, entre os quais o Brasil (BRASIL et al, 1998).

Os dois pilares seriam a ABACC, instituída pelo Tratado de Guadalajara, de 18 de julho de 1991, e o Tratado Quadripartite, constituído em 13 de dezembro de 1991, em Viena. O primeiro se pretendia ser uma agência ampla legitimidade para salvaguardar, de forma ampla e irrestrita, os programas nucleares brasileiro e argentino, visto que, para esses países, a AIEA estava maculada com a predominância dos cinco países nuclearizados e seus interesses de manter o congelamento internacional de poder. $\mathrm{O}$ segundo pilar era uma maneira de incluir a própria AIEA no sistema bilateral de salvaguardas, de modo aceitável tanto a Brasília e Buenos Aires quanto à comunidade internacional. Essa inclusão deveria ocorrer de maneira que a agência pudesse oferecer garantias à comunidade internacional de que Brasil e Argentina não eram países proliferadores de armas nucleares, não obstante não serem aderentes ao TNP.

A ABACC foi instituída em 1991 com o objetivo precípuo de aplicar o Sistema Comum de Contabilidade e Controle de Materiais Nucleares (SCCC) (ABACC, 1993), como definido pelo artigo VII do Tratado de Guadalajara ${ }^{302}$. O SCCC foi instrumento estabelecido pela Declaração sobre Política Nuclear Comum Brasileiro-Argentina, ou Declaração de Foz do Iguaçu, de 1990, o qual representava o "cumprimento do mandato outorgado na Declaração sobre Política Nuclear, de 1985, no sentido de se criarem mecanismos para a manutenção da paz, da segurança e do desenvolvimento na América Latina" (VARGAS, 1997: 54). Tratou-se de um sistema aproximação bilateral que tinha por objetivo instar a realização de inspeções conjuntas entre técnicos brasileiros e argentinos e, dessa forma, fortalecer a aproximação entre os países e produzir relatórios confiáveis à comunidade internacional. Com relação a este ponto, a "harmonização do SCCC com registros e relatórios submetidos por outros países à Agência, conforme os acordos de salvaguardas vigentes, representava buscar uma via híbrida para o cumprimento das exigências da AIEA sem que os dois país estivessem que aderir ao TNP” (VARGAS, 1997: 54).

\footnotetext{
${ }^{302}$ Segundo o artigo VII do Tratado de Guadalajara, "o objetivo da ABACC é administrar e aplicar o SCCC, conforme disposto no presente Acordo.".
} 
A ABACC representou a institucionalização dos dispositivos previstos no SCCC, por meio da criação de organização ${ }^{303}$ bilateral efetiva, com ampla capacidade de movimentação dentro das estruturas estatais brasileira e argentina. A ABACC, cuja estrutura administrativa compõe-se de uma secretaria executiva subdividida em setores técnicos e administrativos ${ }^{304}$, garantiria a transparência dos governos brasileiro e argentina no campo nuclear, bem como a reafirmava, no artigo III, o uso da energia nuclear para propulsão de submarinos - o que foi baseado no artigo $5^{\circ}$ do Tratado de Tlatelolco, e como o compromisso de banir complementarmente armas nucleares de seus territórios. Este ponto é corroborado pelo artigo I do Tratado de Guadalajara, no qual os países reconheceram

\begin{abstract}
"a inexistência de distinção técnica entre explosivo nucleares para fins pacíficos e os destinados a emprego militar, abstendo-se, em consequência, de realizar, fomentar ou autorizar [...] ou de participar de qualquer maneira no teste, uso, fabricação, produção ou aquisição, por qualquer meio, de qualquer dispositivo nuclear explosivo, enquanto persista a referida limitação técnica".
\end{abstract}

A ABACC pretendia-se uma espécie de amortecedor, o qual deveria amainar o impacto das reivindicações da comunidade internacional feitas ao Brasil e à Argentina. Seria, portanto, mecanismo pelo qual os países ingressariam no regime internacional de não proliferação nuclear de modo institucionalizado, bem como instrumento que permitisse, concomitantemente, manter o discurso contestador do congelamento global de poder e garantir a transparência dos rumos das atividades nucleares internas nos dois países. De fato, a ABACC foi criada como um mecanismo exitoso que passou a integrar as organizações de salvaguardas do regime internacional de não proliferação nuclear, as quais abarcam, categoricamente, a AIEA, a Comunidade Europeia de Energia Atômica (EURATOM), a ABACC e, posteriormente, o sistema de verificação FMCT (Fissile Material Cut-off Treaty) (DEUTSCHER BUNDESTAG, 12 dez. 2007).

\footnotetext{
${ }^{303}$ O termo organização internacional aqui adotado refere-se a uma espécie de instituição criada e mantida pela comunidade internacional de maneira formal. Organizações implicam a existência de estrutura física, a possibilidade de tomar empréstimos, orçamento, funcionários, entre outras prerrogativas necessárias a seus funcionamentos. Essas agências "têm a tempo sido vistas como atores capazes de prover bens internacionais coletivos e redistributivos" (SIMMONS, MARTIN, 2007: 192, tradução livre), como a própria manutenção da paz e do desarmamento internacional.

${ }^{304} \mathrm{O}$ organograma da ABACC compõe-se de uma secretaria, dividida em Administrativo-Financeiro, apoio técnico, contabilidade de materiais nucleares, operações, planejamento e avaliação, relações institucionais, planejamento e avaliação, relações institucionais. Além disso, a ABACC conta com uma comissão para orientar e estabelecer os rumos dos trabalhos desenvolvidos, composta por dois representantes argentinos e dois brasileiros.
} 
A configuração de um mecanismo bilateral de salvaguardas e de controle de materiais radioativos foi objeto de discussão continua, a qual pode ser rastreada às duas décadas anteriores. Esse possível mecanismo bilateral fora objeto de diversas formulações e modelos, os quais foram considerados de formas distintas e os quais foram encarnados na $\mathrm{ABACC}$, a qual apresentou, contudo, estrutura orgânica e administrativa única e inovadora. Entre esses modelos, destacar-se-ão aqui quatro modelos específicos, encontrados em fontes distintas e dispersas e expostos no Quadro 8: (1) a Proposta Finley, de 1977; (2) o modelo da EURATOM, instituição europeia desenvolvia em 1957; (3) o Plano Alfonsín, exposto por representantes diplomáticos do governo de Raúl Alfonsín em documentação diplomática enviada ao Brasil; (4) o modelo SCCC/ABACC, que foi aquele, finalmente, firmado entre Brasil e Argentina em 1991, com a assinatura do Tratado de Guadalajara, ratificado em 1994.

Quadro 8 - Propostas para Mecanismo Bilateral para Aproximação Nuclear entre Brasil e Argentina

\begin{tabular}{|c|c|c|c|c|}
\hline Modelo & Proposta Findley & Plano Alfonsín & Modelo EURATOM & SCCC/ABACC \\
\hline Países-Membros & Brasil, Argentina, apenas & $\begin{array}{l}\text { Brasil e Argentina, } \\
\text { apenas }\end{array}$ & $\begin{array}{l}\text { Abrangente. Deveria } \\
\text { englobar todos os } \\
\text { países que tivessem } \\
\text { capacidade nuclear na } \\
\text { América Latina. }\end{array}$ & $\begin{array}{l}\text { Brasil e Argentina, } \\
\text { inicialmente, devendo se } \\
\text { estender a outros países } \\
\text { da América Latina. }\end{array}$ \\
\hline $\begin{array}{c}\text { Grau de } \\
\text { Institucionalização } \\
305\end{array}$ & $\begin{array}{l}\text { Baixo - não previa criar } \\
\text { organização nem sistema de } \\
\text { regras próprio }\end{array}$ & $\begin{array}{l}\text { Médio - não previa } \\
\text { criar organização, mas } \\
\text { previa a criação de } \\
\text { sistema de regras } \\
\text { bilateral próprio. }\end{array}$ & $\begin{array}{l}\text { Alto - implicava o } \\
\text { estabelecimento de } \\
\text { organização nos } \\
\text { moldes da } \\
\text { EURATOM, que fosse } \\
\text { mais amplo do que } \\
\text { salvaguardas e } \\
\text { controle. }\end{array}$ & $\begin{array}{l}\text { Alto - criação de } \\
\text { organização própria, de } \\
\text { instituições bilaterais } \\
\text { normativas de controle } \\
\text { de material radioativo. }\end{array}$ \\
\hline Financiamento & Não mencionado & Não mencionado & $\begin{array}{l}\text { Divisão mista } \\
\text { semelhante à } \\
\text { EURATOM, a qual } \\
\text { variasse de acordo com } \\
\text { o tamanho do parque }\end{array}$ & $\begin{array}{l}\text { Divisão equitativa dos } \\
\text { gastos entre Brasil e } \\
\text { Argentina. }\end{array}$ \\
\hline
\end{tabular}

${ }^{305}$ Institucionalização refere-se ao processo de criar instituições internacionais, estas entendidas, como explicitado anteriormente, como "conjunto de tanto as organizações, estruturas físicas nas quais Estados participam com representantes, quanto o conjunto de normas, valores e regras que regem as relações entre Estados, criando ordem em meio à anarquia internacional" (SIMMONS; MARTIN, 2007: 192, tradução livre). 


\begin{tabular}{|c|c|c|c|c|}
\hline & & & $\begin{array}{l}\text { energético dos países e } \\
\text { do projeto } \\
\text { desenvolvido. }\end{array}$ & \\
\hline Relações com a AIEA & $\begin{array}{l}\text { Sem ligações diretas. Não } \\
\text { substituiria inspeções da } \\
\text { AIEA. }\end{array}$ & $\begin{array}{l}\text { Deveria criar condições } \\
\text { para substituir as } \\
\text { inspeções da AIEA. }\end{array}$ & $\begin{array}{l}\text { Relações institucionais } \\
\text { entre nova organização } \\
\text { e a AIEA. }\end{array}$ & $\begin{array}{l}\text { Aproximação técnica } \\
\text { entre ABACC e AIEA, } \\
\text { definida pelo } \\
\text { Quadripartite. }\end{array}$ \\
\hline $\begin{array}{c}\text { Ambições de Médio e } \\
\text { de Longo Prazos }\end{array}$ & $\begin{array}{l}\text { Sinalizar à comunidade } \\
\text { internacional a inexistência } \\
\text { de corrida armamentista no } \\
\text { Cone Sul. }\end{array}$ & $\begin{array}{l}\text { Permitir à Argentina e } \\
\text { ao Brasil, no médio } \\
\text { prazo, obter } \\
\text { credibilidade ante a } \\
\text { comunidade } \\
\text { internacional sobre o } \\
\text { caráter pacifico de seus } \\
\text { programas nucleares. }\end{array}$ & $\begin{array}{l}\text { Criar uma instituição } \\
\text { capaz de assessorar os } \\
\text { países na condução de } \\
\text { suas políticas nucleares } \\
\text { de modo abrangente, } \\
\text { inclusive no } \\
\text { desenvolvimento de } \\
\text { tecnologia. }\end{array}$ & $\begin{array}{l}\text { Criar condições de } \\
\text { inserir o Brasil e a } \\
\text { Argentina no regime } \\
\text { internacional de não } \\
\text { proliferação nuclear de } \\
\text { modo efetivo. Criar } \\
\text { sistema de contabilidade } \\
\text { e de controle claro e } \\
\text { abrangente, que } \\
\text { mostrasse a } \\
\text { transparência dos países } \\
\text { e que mostrasse } \\
\text { alternativa viável ao } \\
\text { TNP, considerado } \\
\text { anacrônico. }\end{array}$ \\
\hline
\end{tabular}

Fontes: ABACC, 1993; Entrevistas realizadas pelo autor com funcionários da CNEN; MALLEA et al, 2015; MRE, 22 mai 1985; MRE, 13 mai. 1985; MRE, 07 set. 1977; MRE, 10 jan. 198. Elaboração Própria.

O primeiro modelo, a Proposta Findley, tratou-se de proposta individual ainda em estágio pouco elaborado, realizada, de iniciativa pessoal, pelo parlamentar norteamericano Paul Findley, presidente da Comissão de Energia Atômica da Casa dos Representantes, em 1977. Findley viajou a Buenos Aires e a Brasília, onde manteve reuniões bilaterais com autoridades governamentais para argumentar que a criação de sistema bilateral de inspeções poderia mitigar as suspeitas dos Estados Unidos e de outros países obre as intenções atômicas de ambos os países (SPEKTOR, 2015). Essa proposta foi publicada no periódico americano Washington Post e permitiu a publicidade necessária para que o parlamentar enviasse sua proposta ao GeneralPresidente Videla, na Argentina, e ao Vice-Presidente brasileiro, Adalberto Pereira dos Santos (MALLEA, SPEKTOR, 2015).

Como apresentada, a proposta resumia-se à indicação da necessidade de se realizarem inspeções nucleares conjuntas, nas quais cada país permitiria que inspetores do outro país verificassem seus estoques de materiais radioativos e monitorassem suas instalações nucleares. Essas inspeções bilaterais não se propunham a substituir, como exposto no Quadro 8, o firmamento de acordos bilaterais com a AIEA, mas permitiria 
sinalizar à comunidade internacional o compromisso brasileiro e argentino com a não proliferação de armas nucleares e evitar uma corrida armamentista no Cone Sul ${ }^{306}$. Essa proposta exerceu pouca influência no lado brasileiro, no qual, sequer, é mencionada por atores relevantes ou por abrangente documentação nacional, salvo menção a ela é feita em relatório sobre a reunião entre o Vice-Presidente e o congressista americano ${ }^{307}$. Do lado argentino, contudo, ela obteve maior receptividade, e pode ter influído nas definições posteriores apresentadas por aquele governo, em especial na proposta de Alfonsín.

O segundo modelo, o Plano Alfonsín, é o nome que aqui se dá a uma série de indicações do presidente argentino Raúl Alfonsín no sentido de criar com o Brasil "um sistema de controle bilateral das aplicações da energia nuclear num e noutro país, a ser criado exclusivamente no âmbito brasileiro-argentino, consoante padrões próprios a serem estabelecidos" (MRE, 22 mai. 1985). Essas indicações foram feitas pelo governo Alfonsín a representantes do presidente eleito Tancredo Neves e foram, depois, retomadas, porém de maneira menos significativa, com o governo Sarney. A iniciativa de Alfonsín diferenciou-se, de modo relevante, da Proposta Findley, por se propor a ser mecanismo auto-suficiente em relação à AIEA, ou seja, pretendia-se ser garantias suficientes à comunidade internacional, as quais tornassem desnecessária futura adesão ao TNP (MRE. 13 mai. 1985).

O modelo de Alfonsín, por um lado, diferenciou-se, igualmente, da ABACC, depois conformada, por não prever algo grau de institucionalização, mas, tão somente, um conjunto de medidas de auto-regulação bilateral, o que era visto como necessário, até mesmo, para conferir aura de legitimidade e retirar as suspeitas que pairavam sobre o programa nuclear autônomo argentino ${ }^{308}$. Por outro lado, como será a ABACC, o

\footnotetext{
${ }^{306}$ Proposta Findley, MRE 07 set. 1977.

${ }^{307}$ Sumário do documento MRE, 07 set. 1977, realizado pelo Wilson Center: "Vice-President Adalberto Pereira reports on a meeting with Republican Congressman Paul Findley, who proposed, on a personal basis, the creation of a nuclear mutual surveillance system between Brazil and Argentina, with a view to allaying doubts about a possible arms race. Findley had already presented the proposal to Ambassador Geraldo Holanda Cavalcanti, (aide to Minister Silveira) on the occasion of the visit to Brasilia on August 23 1977. According to the agreement he proposed, Brazil and Argentina would renounce the intention to develop a nuclear device and would accept mutual inspections of their respective nuclear facilities."

${ }^{308}$ Segundo análise de Rubens Barbosa, chefe do DEC-MRE, ““ao propor um sistema de autocontrole na região, o Presidente Alfonsín estaria indiretamente dando ao programa nuclear argentino, sobre e sua vertente autônoma, uma maior legitimidade, protegendo-o das suspeitas sobre as intenções militares que pairam sobre esse programa, reforçadas pela frustração argentina no conflito das Malvinas e pelo anúncio subsequente do êxito tecnológico em enriquecer urânio. As vicissitudes pelas quais passa o programa argentino, em função da escassez de recursos financeiros, e de obstáculos crescentes na aquisição de
} 
Plano Alfonsín de autocontrole nuclear tinha como meios o intercâmbio entre técnicos e tinha como objetivo ser um mecanismo que possibilitasse "colocar o programa nuclear argentino no contexto de uma moldura legal abrangente, capaz de valer-lhe o apoio da opinião pública interna e internacional.” (MRE, 10 jan. 1985: 3).

O terceiro modelo é aquele semelhante ao da EURATOM, o qual, apesar de não ter sido considerado diretamente para o caso Brasil-Argentina serviu de inspiração e de lição para uma possível aproximação bilateral no campo (GOLDMAN, 1991). Do modelo da EURATOM foram aproveitadas algumas lições como o escopo das inspeções e o modelo de se aplicar salvaguardas regionais abrangentes. A ideia inicial desse modelo, qual seja, estabelecer uma organização nos moldes da EURATOM, com amplo secretariado e com projetos abrangentes de pesquisa tecnológica conjunta na área atômica, foi descartada logo nos planos iniciais. Uma dos motivos para esse descarte era a preocupação em tornar a nova organização algo eficiente, plausível e o qual, ao mesmo tempo, fosse aceito pela comunidade internacional e pelos dois países que a compunham (GOLDMAN, 1991).

Por fim, após esses múltiplos modelos iniciais, partiu das Presidências da República brasileira e argentina, sob Collor e Menem, respectivamente, a decisão de implementar instituição distinta, em modelo único e distinto dos demais apresentados. $\mathrm{O}$ modelo da ABACC foi definido após uma série de reuniões entre

"representantes do Brasil e da Argentina, incluindo Diplomatas do Itamaraty e da Chancelaria Argentina, e de técnicos de salvaguarda de ambos os países $\left(\mathrm{CNEN}^{309}\right.$ e CNEA), para estruturar as bases técnicas e procedimentais para a

tecnologia e materiais nucleares no exterior, seriam mais facilmente contornadas numa atmosfera de confiança e respeitabilidade gerada no bojo de uma iniciativa argentina em favor da não-proliferação na América Latina“" (MRE, 30 abril 1985: 3).

${ }^{309}$ Além dos modelos expostos, pode-se salientar um conjunto de conversas informais entre o professor Glenn Seaborg, químico nuclear e diretor da Comissão de Energia Atômica dos Estados Unidos, e membros técnicos brasileiros da CNEN, entre os quais o presidente da comissão durante o governo Collor, José Luiz de Santana Carvalho. Seaborg teria retomado ideias expostas pelo ex-Secretário de Estado dos governos Nixon e Ford, Henry Kissinger, no sentido da necessidade de aplicar a política de compartilhamento de poder com potências regionais - a política dos círculos minguantes - no campo nuclear. No caso da América Latina, isso poderia dar-se por meio de um programa conjunto de enriquecimento de urânio, no qual os países, em conjunto, monitorar-se-iam uns aos outros e, assim, reduziriam os custos de ingerência do hegemón norte-americano. Em suas memórias, Seaborg (1996) reconhece, após visitas por ele realizadas à América Latina, na condição de diretor da Comissão de Energia Atômica dos Estados Unidos, o grau avançado em que se encontravam os programas nucleares na sub-região, bem como a importância da tecnologia nuclear para o desenvolvimento regional. Além disso, ele afirmou que os laborátorios nucleares na Argentina e no Brasil "ofecereciam excelentes perspectivas para serem usados como centros regionais para programas de cooperação multinacional" (SEABORG, 1996: 260). 
implementação dessas inspeções cruzadas de salvaguarda, no âmbito de um novo sistema denominado de 'Sistema Comum de Contabilidade e Controle de Materiais Nucleares (SCCC)', concebido com base nas medidas descritas para a aplicação do TNP"310.

Nesse processo negociador, foi-se gradualmente abandonando a ideia inicial de oficializar programa de inspeções conjuntas realizadas por técnicos da CNEN e da CNEA ou de inspeções cruzadas, as quais já teriam ocorrido, de modo ilustrativo, nos governos Sarney-Alfonsín. Esse abandono, o qual significou parcial descarte dos modelos Findley e Alfonsín, levou os negociadores a algo mais próximo do modelo EURATOM, pois se percebeu ser necessidade de criar uma organização independente que contivesse e que aplicasse, livre de ingerências políticas externas, o SCCC. Surgiu daí a ideia da ABACC, a qual deveria constituir instrumento para a operacionalização do SCCC, por meio de vias próprias, porém amplamente aceitas por ambos os países. Criou-se, por fim, um sistema interligado entre a os dois países e a nova organização, no qual a ABACC, além de possuir funcionários e orçamento próprios, poderia dispor de técnicos da CNEN e da CNEA, inclusive nas inspeções conjuntas realizadas com a $\mathrm{AIEA}^{311}$.

Além da $\mathrm{ABACC}$, o outro pilar fundamental do sistema de ingresso no regime internacional de não proliferação nuclear ensejado pelo Brasil e pela Argentina foi o Acordo Quadripartite Argentina-Brasil-ABACC-AIEA, firmado em 13 de dezembro de 1991. Esse acordo aproximou, de fato, os dois maiores países sul-americanos da AIEA, o que deveria sinalizar à comunidade internacional o caráter pacífico e a transparência dos programas nucleares. Essa aproximação, realizada sob a roupagem de um tratado jurídico reconhecido pelo direito internacional, deveria ser o principal fator a permitir a

\footnotetext{
${ }^{310}$ Entrevista escrita concedida por Sílvio de Almeida ao autor, em 25 fev. 2016.

311 Segundo Sílvio de Almeida, em entrevista concedida ao autor, em 25 fev. 2016, cabe "ressaltar também que, já no âmbito do SCCC e para a implementação do Acordo Quadripartite, ambas as Autoridades Nacionais (CNEN e ARN) e CNEA se comprometem a fornecer todo o suporte técnico e humano (especialistas e inspetores) que a ABACC vier a necessitar para o cumprimento de sua missão. Com isso, muitas vezes na condução ou mesmo na preparação de alguma atividade conjunta, a ABACC tem prestado à AIEA enormes contribuições para o sucesso das missões ou no desenvolvimento de sistemas envolvendo procedimentos". Além disso, o antigo inspetor da agência lembrou que "a ABACC não só administra a implementação do SCCC como atua como coordenadora [de] todas as inspeções conjuntas ABACC-AIEA conduzidas nas instalações brasileiras e argentinas, sendo mantido o conceito inicialmente estabelecido das inspeções cruzadas entre brasileiros e argentinos, nomeados inspetores da ABACC.".
} 
"renovação de credenciais" brasileira no campo nuclear, sem, contudo, implicar adesão imediata do Brasil ao $\mathrm{TNP}^{312}$.

Isso seria possível porque o INFCIRC/435, instrumento associado que instituiu o Quadripartite, permitiu à AIEA, em conjunto e coordenada pela ABACC, realizar salvaguardas abrangentes ${ }^{313}$ nas instalações nucleares do Brasil e da Argentina (GUIMARÃES, 2011). Além disso, o Quadripartite substituiu todos os antigos acordos firmados entre o Brasil e a AIEA (i.e. os acordos trilaterais Brasil-Estados UnidosAIEA, de 1972, e Brasil-Alemanha-AIEA, de 1976), os quais haviam sido firmados "segundo o modelo INFCIRC/66 da AIEA (salvaguardas parciais, de aplicação a instalações especificas) usados para importação de sistemas, como Angra 1 e as instalações contratadas dentro do escopo do Acordo Nuclear Brasil-Alemanha" (GUIMARÃES, 2011).

Apesar de o Quadripartite somente ter sido ratificado em 1994, no governo Itamar Franco, a ABACC já começou a funcionar no ano de 1992, inclusive com aproximação institucional com a AIEA. A efetividade dessa instituição pode ser ilustrada, principalmente, por dois dados: orçamento e quantidade de inspeções realizadas. Segundo o Quadro 8, verifica-se, no lado financeiro, tanto que foi respeitada a divisão equânime de custos entre Brasil e Argentina quanto que o orçamento total da agência cresceu, progressivamente, entre 1992 e 1999, de modo que o orçamento total de 1999 (US\$ 3.691.050,21) foi 45\% maior do que aquele de 1993 (US\$ 2.545.327,16). Esse dado tende a demonstrar aumento das atividades realizadas e consolidação da estrutura administrativa e técnica, uma vez que as despesas totais aumentam em $82 \%$.

Do lado das inspeções, assim como exposto pelo Quadro 9 e representado pelo Gráfico 2, verificou-se leve e constante queda das inspeções realizadas após o pico observado em 1994, quando foram realizadas 186 inspeções. Entre o mencionado pico e o ano de 1999 (133 inspeções) verificou-se queda de 39\% do número total de inspeções realizadas - o que demonstra não uma queda constante, mas apenas o grande esforço

\footnotetext{
${ }^{312}$ O modo como a ABACC passou a estruturar-se entre 1994, data da adesão da Argentina ao TNP, e 1998, quando o Brasil aderiu àquele tratado, pode ser encontrada na figura Anexo 6.

${ }^{313}$ Segundo o Artigo $1^{\circ}$ do Acordo Quadripartite, de 1991, define como compromisso básico do tratado: "Os Estados-Partes comprometem-se, em conformidade com os termos do presente Acordo, a aceitar a aplicação de salvaguardas a todos os materiais nucleares em todas as atividades nucleares realizadas dentro de seu território, sob sua jurisdição ou sob seu controle em qualquer lugar, com o objetivo único de assegurar que tais materiais não sejam desviados para aplicação em armas nucleares ou outros dispositivos nucleares explosivos".
} 
realizado no ano pico, uma vez que, entre 1995 e 1999 a queda foi de, apenas, 16,4\%. Longe de representar uma redução dos esforços, essa queda pode demonstrar que já haviam sido realizadas suficientes inspeções nos anos anteriores, de modo que as posteriores passaram a adquirir caráter de rotina. Além disso, deve-se ressaltar que, exceto pelo ano de 1996, em todos os demais o número de inspeções realizadas na Argentina foi maior do que aquele realizado no Brasil, sendo essa diferença mais notória no ano pico de 1994, quando foram realizadas 22 inspeções a mais no lado argentino do que no brasileiro.

Quadro 9: Manutenção e trabalhos da ABACC - 1993-1999

\begin{tabular}{|c|c|c|c|c|c|c|c|c|c|}
\hline & & 1992 & 1993 & 1994 & 1995 & 1996 & 1997 & 1998 & 1999 \\
\hline \multirow[t]{3}{*}{$\begin{array}{l}\text { Receitas } \\
\text { (US\$) }\end{array}$} & Brasil & N/D & $\begin{array}{l}1.237 .500, \\
00\end{array}$ & $\begin{array}{l}1.257 .375, \\
00\end{array}$ & $\begin{array}{l}1.250 .000, \\
00\end{array}$ & \multirow{2}{*}{$\begin{array}{l}2.926 .392, \\
03 \\
(\mathrm{Br}+\mathrm{Ar})\end{array}$} & \multirow[t]{2}{*}{$\begin{array}{l}3.050 .00,0 \\
0(\mathrm{Br}+\mathrm{Ar})\end{array}$} & \multirow{2}{*}{$\begin{array}{l}3.075 .000, \\
00 \\
(\mathrm{Br}+\mathrm{Ar})\end{array}$} & \multirow{2}{*}{$\begin{array}{l}3.050 .000, \\
00 \\
(\mathrm{Br}+\mathrm{Ar})\end{array}$} \\
\hline & Argentina & N/D & $\begin{array}{l}1.237 .500, \\
00\end{array}$ & $\begin{array}{l}1.260 .000, \\
00\end{array}$ & $\begin{array}{l}1.250 .000 \\
00\end{array}$ & & & & \\
\hline & Total & N/D & $\begin{array}{l}2.545 .327 \\
16\end{array}$ & $\begin{array}{l}2.692 .847, \\
05\end{array}$ & $\begin{array}{l}2.587 .157 \\
70\end{array}$ & $\begin{array}{l}3.422 .137, \\
83\end{array}$ & $\begin{array}{l}3.618 .643, \\
80\end{array}$ & $\begin{array}{l}3.075 .000, \\
00\end{array}$ & $\begin{array}{l}3.691 .050, \\
21\end{array}$ \\
\hline $\begin{array}{l}\text { Despesas } \\
\text { (US\$) }\end{array}$ & Total & $\mathrm{N} / \mathrm{D}$ & $\begin{array}{l}1.534 .116 \\
04\end{array}$ & $\begin{array}{l}2,295,626 . \\
20\end{array}$ & $\begin{array}{l}2,718,999 . \\
76\end{array}$ & $\begin{array}{l}2.834 .011, \\
30\end{array}$ & $\begin{array}{l}3.308 .347, \\
62\end{array}$ & $\begin{array}{l}3.135 .627, \\
69\end{array}$ & $\begin{array}{l}2.799 .307, \\
53\end{array}$ \\
\hline \multirow{3}{*}{$\begin{array}{c}\text { Inspeções } \\
\text { acompanhad } \\
\text { as pela AIEA }\end{array}$} & Brasil & N/D & N/D & N/D & N/D & 10 & 7 & $\mathrm{~N} / \mathrm{D}$ & N/D \\
\hline & Argentina & N/D & N/D & N/D & N/D & 13 & 1 & N/D & N/D \\
\hline & Total & N/D & N/D & N/D & N/D & 23 & 8 & N/D & N/D \\
\hline \multirow{3}{*}{$\begin{array}{l}\text { Total de } \\
\text { Inspeções }\end{array}$} & $\overline{\text { Brasil }}$ & N/D & N/D & 82 & 72 & 81 & 66 & 62 & N/D \\
\hline & Argentina & N/D & N/D & 104 & 77 & 79 & 76 & 66 & N/D \\
\hline & Total & 11 & 35 & 186 & 149 & 159 & 142 & 128 & 133 \\
\hline \multirow{3}{*}{$\begin{array}{l}\text { Esforço de } \\
\text { inspeção } \\
\text { (inspetores/di } \\
\text { a) }\end{array}$} & $\overline{\text { Brasil }}$ & N/D & N/D & 557 & 131 & 198 & 127 & 129 & N/D \\
\hline & Argentina & N/D & N/D & 949 & 579 & 425 & 352 & 295 & N/D \\
\hline & Total & 28 & 106 & 562 & 683 & 626 & 479 & 424 & 449 \\
\hline
\end{tabular}

Fonte: ABACC, relatórios anuais 1993-1999. Elaboração Própria. 


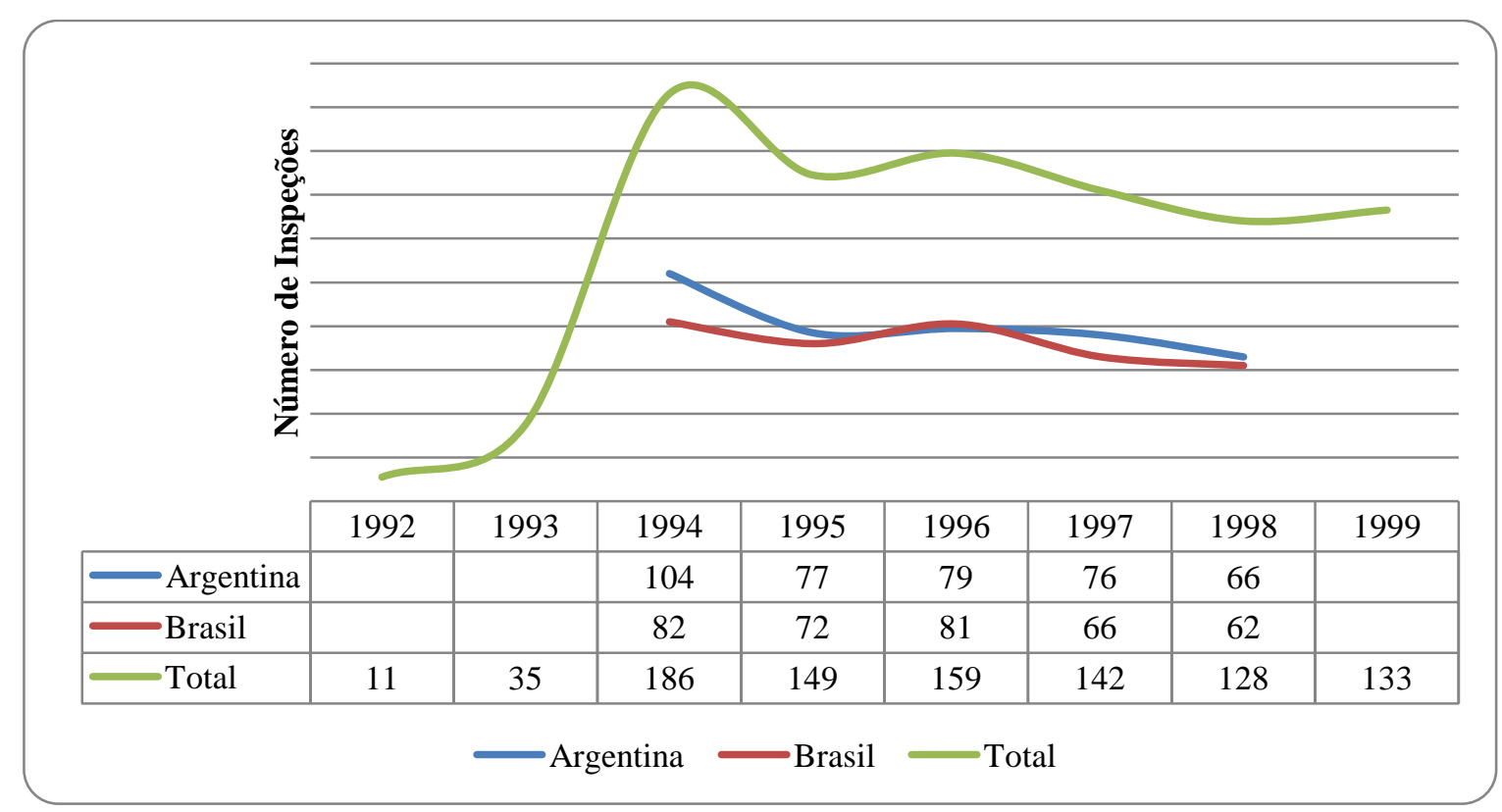

Fonte: ABACC, relatórios anuais 1993-1999. Elaboração Própria.

Após análise dos dados disponíveis relativos à condução dos trabalhos da ABACC no período abarcado entre 1992 e 1999, percebe-se, que apesar da certa inconstância verificada, por exemplo, na comparação entre as inspeções realizadas entre Brasil e Argentina, a organização aparentou mostrar certa funcionalidade. Essa funcionalidade seria indicativo de que cumpriu seus objetivos iniciais previstos de instituir garantias de transparência à comunidade internacional quanto ao caráter pacifista dos programas nucleares brasileiro e argentino. Essas garantias, como se verá a seguir, foram aceitas e reconhecidas por parte dos países do Norte Global, em especial pelos Estados Unidos, não obstante a não adesão do Brasil ao TNP.

\section{A Reaproximação com o Eixo Assimétrico: Alemanha, Estados Unidos, TNP.}

Outra face importante da política nuclear brasileira entre 1990 e 1998 foram as relações com o Eixo Assimétrico, propriamente ditas. Essas relações tiveram especial ênfase, novamente, nas relações com os Estados Unidos e com a Alemanha, assim como ocorrido durante os anos 1969 e 1978, porém com a busca, agora, pela normalização das relações bilaterais Essa normalização se incluía no esforço dos governos Collor-FrancoCardoso de adequar a política nuclear e externa brasileira ao novo momentum das 
relações internacionais e ao novo contexto global pós-Guerra Fria. Isso envolveria, nos governos Collor e Franco, a gradual aproximação com o regime internacional de não proliferação nuclear, via ABACC e Quadripartite, e, no governo Cardoso, a adesão ao TNP. Esta, em particular, terá como uma de suas principais justificativas os prováveis benefícios antevistos com os Estados Unidos (o que será aqui questionado).

Com a Alemanha, as relações bilaterais no campo nuclear passaram por nova aproximação ao longo da década de 1990. Essa aproximação ocorreu após a progressiva desilusão ocorrida entre 1979 e 1989 e reverberou com a assinatura do Acordo bilateral de 1994, o qual substitui aquele de $1975^{314}$. Diferentemente da década de 1970, quando o chanceler Helmut Schmidt procurou implementar o Sonderweg em temas de cooperação nuclear, na década de 1990, o governo de Helmut Kohl e da coalizão União Cristã Democrática da Alemanha/União Social Cristã da Bavária (CDU/CSU) mantiveram política de baixo perfil no campo atômico. Isso ocorreu tanto devido às mudanças do enfoque da política externa alemã (VON BREDOW, 2006), especialmente após a reunificação e a criação de União Europeia, pelo Tratado de Maastricht (1992), quanto devido à mudança de rumos da política energética alemã, cada vez mais voltada para a ênfase em fontes sustentáveis alternativas e mais influenciada pela presença do Partido Verde no Bundestag ${ }^{315}$, este contrário ao uso da energia nuclear.

A renegociação do acordo de 1994 com a Alemanha foi fundamental para a conformação do Quadripartite, o qual substituía provisões contidas nos acordos de 1975 e de 1976 (Acordo Trilateral Brasil-Alemanha-AIEA) e transferia para a agência o mecanismo bilateral de salvaguardas, pelo qual inspetores teriam amplo acesso às instalações atômicas brasileiras ${ }^{316}$. Fora, então, abandonado o dispositivo do tratado de 1975 que impunha a necessidade de ao Brasil ser necessário requisitar à Alemanha autorização para negociar a compra e a venda de tecnologia com países terceiros (artigo $4^{\mathrm{o}}, 2$, do Acordo de 1975$)^{317}$. A negociação com os alemães para o abandono das

\footnotetext{
${ }^{314}$ DEUTSCHER BUNDESTAG, 12 dez. 2007

${ }^{315}$ Vale salientar que o Partido Verde alemão (Bündnis 90/ Die Grünen) chegará, inclusive, a ocupar a chancelaria em Berlim entre 1998 e 2005, quando a coalizão Partido Social Democrático / Partido Verde elegeu Gerhard Schöder. Uma das tradicionais bandeiras do Partido Verde, em especial após o desastre nuclear de Chernobyl, é o abandono da energia nuclear.

${ }^{316}$ Entrevista com José de Santana Carvalho (18 fev. 2016).

317 "Os materiais, equipamentos e instalações nucleares sensitivos exportados, bem como as respectivas informações tecnológicas transmitidas, do território de uma Parte Contratante para o território da outra só poderão ser exportados, reexportados ou transmitidas para terceiros países com o consentimento da Parte Contratante fornecedora." (BRASIL, ALEMANHA, 1975. Artigo 4 ${ }^{\circ}$ 2)
} 
restrições do Acordo e 1975 foi realizada antes do firmamento do Quadripartite, ainda no governo Collor, quando a CNEN passou a adotar postura firmemente contrária àquele tratado, que já se havia, na prática, transformado em "mero acordo comercial/industrial" ${ }^{318}$, e passou a advogar a ideia de sua substituição por salvaguardas da AIEA.

Para concretizar essa ideia, o governo brasileiro implementou estratégia de lobby em Berlim, buscando apoio de forças como o Partido Verde (o qual tinha potencial de tornar-se o principal opositor ao abandono do Acordo de 1975) e buscando utilizar o próprio sistema legal alemão em benefício dos interesses brasileiros. No meio jurídico, argumentou o Brasil que o Estado Alemão e a KWU poderiam ser alvos de processo, dada a inviabilidade do jato centrífugo ${ }^{319}$, argumentação essa crucial para convencer os alemães a abandonar as vantagens que haviam obtido em 1975 do Brasil e a permitir que a primazia de inspetores alemães fosse substituída pela de técnicos da AIEA afinal, afirmou o Brasil, a AIEA representava a comunidade internacional, da qual a Alemanha era parte. Ao final, Berlim aceitou, por meio de seu parlamento, abandonar as diretrizes do Acordo de 1975 e de seus protocolos adicionais, de 1979, desde que fossem confirmados os mecanismos previstos pelo Quadripartite ${ }^{320}$, por cuja iniciativa a Alemanha congratulou Brasília e Buenos Aires, e desde que fosse logo firmado novo acordo bilateral $^{321}$.

\footnotetext{
${ }^{318}$ Depoimento de Pedro Paulo Leoni Ramos à CPMI de 1990 sobre o programa nuclear paralelo (CN, 1990: 95-96)

319 "Os aliados na Alemanha eram o Partido Verde. Eles eram contra o acordo Brasil-Alemanha. Quando um funcionário da CNEN [optou-se aqui por não divulgar o nome] conversou com membros do $\mathrm{PV}$, a coisa melhorou muito, pois era coisa de credibilidade pessoal. O Brasil era transparente. Ele pediu para eles não se oporem à troca de salvaguardas alemãs pela da AIEA. Quando falou a troca de salvaguardas pela da agência (comunidade internacional), não faria sentido manter a dos alemães, porque eles [os alemães] também eram comunidade internacional. Por isso, eventualmente, o Brasil pôde usar as instalações Brasil-Alemanha dentro do nosso acordo [o Quadripartite]. O argumento para tirar o Acordo com a Alemanha [foi] outro: a tecnologia [do jato centrífugo]não funciona! Até agora, vocês não mostraram um miligrama enriquecido com essa tecnologia! Ai, [os assessores jurídicos do governo brasileiro] consultaram advogados alemães que disseram que, dentro de uma situação como essa, os alemães tinham de entregar um quadro técnico da tecnologia. Se esse quadro técnico [sobre o jato centrífugo] se tornasse inviável, como aconteceu, [...] o Brasil teria direito a ser ressarcido naquilo que tinha gastado até então e, ai, quebrar com o contrato. Esse foi um outro argumento muito forte para "tirar a Alemanha do meio" - pois eram várias [as] "instalações" construídas dentro do acordo Brasil-Alemanha (Nuclei, Nuclep etc.)" (Entrevista com José Luiz de Santana Carvalho ao autor, em 18 fev. 2016)

${ }^{320 " D i e ~ B u n d e s r e g i e r u n g ~ b e f u ̈ r w o r t e t ~ e i n e ~ e n g ~ a n ~ b e s t e h e n d e ~ u n d ~ b e w a h r t e ~ V e r i f i k a t i o n s r e g i m e s ~-~ d a z u ~}$ zahlen das Safeguards-System der IAEO, EURATOM sowie die Argentinisch-Brasilianische Behörde für die Kontrolle nuklearer Materialien (ABACC) - anknüpfende FMCT-Verifikation." (DEUTSCHER BUNDESTAG, 12 set. 2007)

${ }^{321}$ DEUTSCHER BUNDESTAG, 1 abr. 2014; DEUTSCHER BUNDESTAG, 12 set. 2007
} 
Dessa forma, negociado plenamente do Quadripartite, iniciar-se-ão as negociações para novo acordo bilateral com a Alemanha, as quais foram, contudo, atrasadas por causa da turbulência política que marcou a queda do governo Collor. O novo acordo foi assinado e ratificado em 1994. Diferentemente do Acordo de 1975, o de 1994 tinha texto mais brando e menos restritivo com relação à possibilidade de o Brasil atuar livremente no mercado internacional nuclear. Isso decorria da consolidação de entendimento em Berlim segundo o qual o Brasil havia firmado, por outros meios, como o Quadripartite e a aproximação com Tlatelolco, suficientes medidas de salvaguardas de seu programa nuclear ${ }^{322}$. De fato, a própria percepção dos alemães sobre o Brasil haviase modificado durante a década de 1990: enquanto, nos anos 1970 e 1980, o Brasil era visto como parceiro promissor, porém com o qual seria necessário firmar consistentes mecanismos de salvaguardas; na década de 1990, o Brasil passa a ser percebido como uma possível potência nuclear ${ }^{323}$ latente $^{324}$, a qual se havia comprometido a não proliferar armas nucleares e a qual havia sido suficientemente abarcada pelo regime internacional de não proliferação ${ }^{325}$.

Sob o novo acordo, conforme ilustrado pelo Quadro 10, a Alemanha continuou a exportar pastilhas de urânio ao Brasil para o facilitar o funcionamento das usinas nucleares de Angra. Essas exportações intensificaram-se em 1999, por fatores não expostos, porém que poderiam incluir a adesão do Brasil ao TNP ou a reorganização institucional do programa nuclear brasileiro, com o fortalecendo da INB, criada em 1988 para substituir a Nuclebrás e que, em 1994, passou a controlar a Nuclei e a Nuclemon. Também interessante ressaltar que, a partir de 2001, o Brasil importou Hexafluoreto de Urânio da URENCO, empresa com a qual o Brasil não conseguiu, no

\footnotetext{
${ }^{322}$ DEUTSCHER BUNDESTAG, 1 abr. 2014

323 "Neben den fünf Kernwaffenstaaten ist die Technologie zur Urananreicherung nach Kenntnis der Bundesregierung in unterschiedlichen Ausbaustufen in Argentinien, Australien, Brasilien, Deutschland, Indien, Iran, Japan, Niederlande, Pakistan und Südafrika vorhanden. Der Bau einer einfachen Kernwaffe auf der Basis von waffenfähigem hochangereicherten Uran wäre von allen genannten Staaten zu bewerkstelligen." (DEUTSCHER BUNDESTAG, 1 abr. 2014)

${ }^{324} \mathrm{O}$ termo "potencia nuclear latente" refere-se àqueles países que possuiriam conhecimento e tecnologia nuclear suficiente para construir armas atômicas "a qualquer tempo", caso uma decisão política em prol da nuclearização fosse feita (TELLIS, 2013-2014: 15, tradução livre). Atualmente, exemplos mais claros sobre potências nucleares latentes são países asiáticos, como o Japão, Coreia do Sul e Austrália (TELLIS, 2013-2014).

325 "Die Nuklearanlagen Brasiliens und Japans unterliegen Sicherungsmaßnahmen der IAEO. Beide planen den weiteren Ausbau der friedlichen Nutzung der Kernenergie im Rahmen des Nichtverbreitungsvertrages. Es gibt aus der Sicht der Bundesregierung keine Zweifel daran, dass sich Japan und Brasilien an die von ihnen eingegangenen Verpflichtungen aus Nichtverbreitungsvertrag und Safeguardsabkommen halten.." (DEUTSCHER BUNDESTAG, 1 abril 2014.)
} 
governo Geisel, firmar acordo de cooperação tecnológica, devido a negativas da Holanda e do Reino Unido a atividades como, justamente, a exportação de urânio de ao Brasil (vide capítulo 2).

Quadro 10 - Exportações e Importações de material radioativo da Alemanha para o Brasil

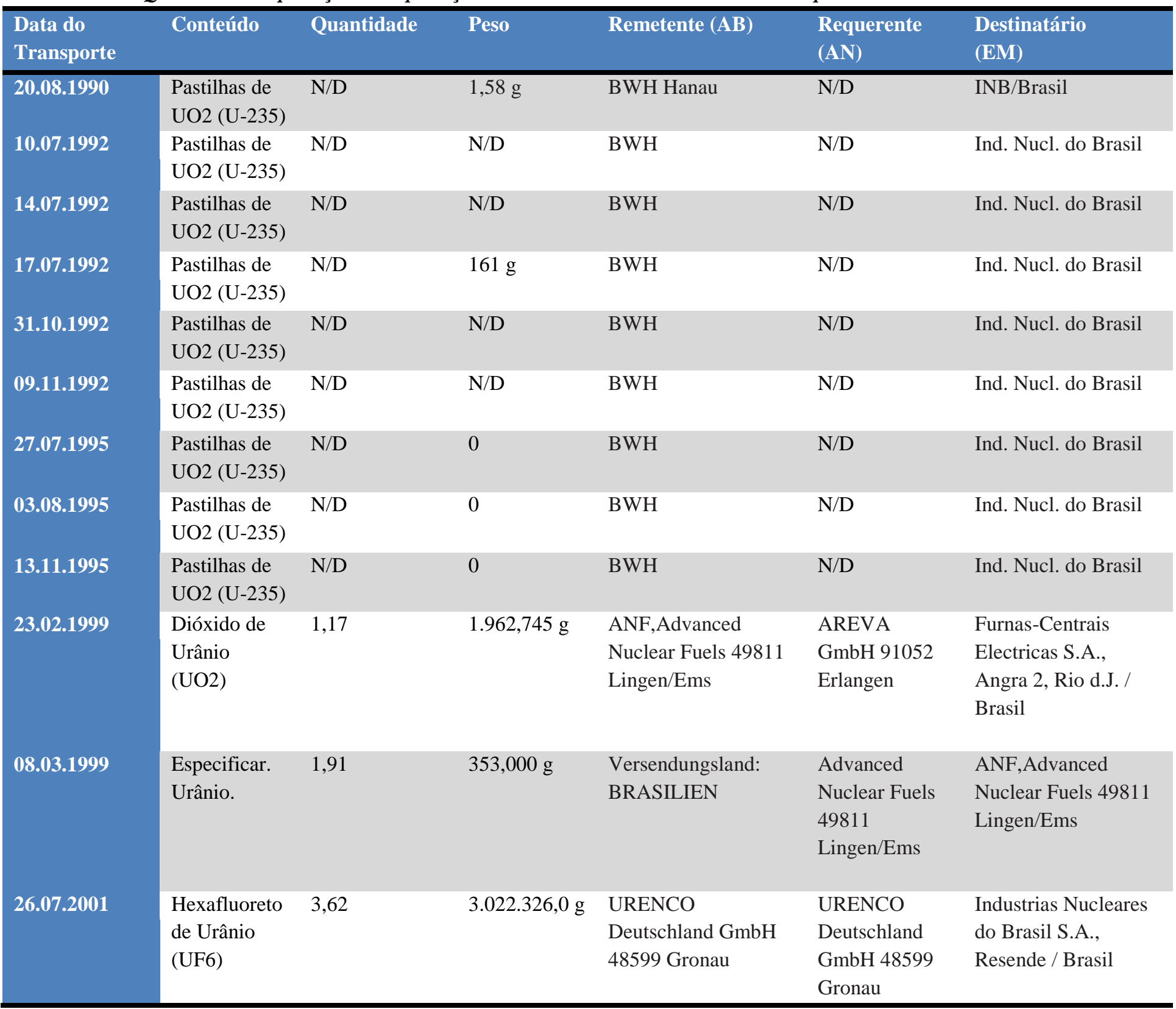

Fonte: DEUTSCHER BUNDESTAG. Drucksache 18/552. Antwort der Bundesregierung ; Drucksache 12/6056 - Atomtransporte. 18 Wahlperiode., 18 fev. 2014. Elaboração Própria 
Ainda no que concerne às relações com o Norte Global, talvez um dos elementos mais relevantes a serem analisados seja a adesão brasileira ao TNP. Essa adesão, culminância do processo de gradual e contínua adesão do Brasil às instituições partes do regime internacional de não proliferação nuclear, foi, conforme já explicitado, definida de modo quase unânime pelos principiais atores internos na condução da política nuclear $^{326}$. Essa unanimidade decorria da confirmação da escolha inequívoca do Brasil por não obter armas nucleares e do abandono das explosões nucleares pacificas, o que possível mediante a consolidação do poder civil no Poder Executivo (VELÁZQUEZ, 2004) e o afastamento dos principais grupos autonomistas bélicos dos centros de poder. Além disso, vale salientar que essa adesão realizou-se após terem sido discutidas posições políticas comuns entre o Grupo dos Oito $^{327}$ e África do Sul, Argentina, Brasil, China, Filipinas e Ucrânia sobre a não proliferação de armas nucleares ${ }^{328}$, no sentido de esses países afirmarem a necessidade de evitar o aumento do número de arsenais nucleares ao redor do globo e de se fortalecer as instituições internacionais de não proliferação nuclear (BRASIL et al., 19 jun. 1998).

A adesão ao TNP é tema complexo e controverso, porquanto o Brasil já havia desenvolvido suficientes instituições que garantissem à comunidade seu compromisso com o uso de tecnologia nuclear para fins exclusivamente pacíficos, o que pode ser corroborado pelo ingresso do país no GSN, dois anos antes de aderir ao TNP. Além disso, como explicitado, o Quadripartite já havia estabelecido mecanismo de salvaguardas e de contabilidade de materiais nucleares abrangente, conduzido pelo AIEA e equivalente aos dispositivos de salvaguardas abrangentes previstos no TNP (CERVO, BUENO, 2011; MONIZ BANDEIRA, 2004), bem como a adesão a Tlatelolco já havia incluído o Brasil em um mecanismo multilateral abrangente que proibia a produção de armas nucleares supervisionado por uma organização específica, a OPANAL (DAWOOD, HERZ, 2013). Isso posto, pode-se considerar, conforme ressaltam Luís Schenoni e Carlos Escudé, em entrevista concedida ao autor, em 23 de março de 2016, que, após a adesão argentina ao TNP, 1994, o Brasil deixou de estar em

\footnotetext{
${ }^{326}$ LAMPREIA ( $2^{\mathrm{a}}$ entrevista. 29 jan. 2008)

327 O Grupo dos Oito (G8) é uma coalizão internacional criada para reunir os sete países mais industrializados e economicamente desenvolvidos do mundo (Estados Unidos, Alemanha, Canadá, França, Itália, Japão, Reino Unido) e a Rússia, sucessora da antiga superpotência soviética).

${ }^{328}$ LAMPREIA, 01 aug. 1998.
} 
uma posição de isolamento e aceitou tornar-se "tomador de regras" no regime internacional de não proliferação nuclear ${ }^{329}$.

Apesar desses pontos, a adesão ao TNP era considerada pelo governo Cardoso como consequência natural do processo que vinha se desenvolvendo de aproximação com o regime de não proliferação nuclear. Essa aproximação implicaria modificar a tradicional postura brasileira de críticas severas ao TNP e que justificariam seu repúdio pelo Brasil, ou seja, a consideração de que aquele tratado garantia o congelamento de poder injusto, desfavorável aos países em desenvolvimento e ineficaz no campo da não proliferação horizontal. Essa modificação, para Cardoso e Lampreia, não deveria implicar críticas ao TNP, as quais, inclusive, eram compatíveis com o conceito da globalização assimétrica, mas modificaria o modo como aquelas críticas seriam feitas ao invés de instarem o afastamento do Brasil do regime internacional de não proliferação, elas deveriam ser levadas ao cerne do regime, por meio da estratégia de autonomia pela integração (VIGEVANI et al, 2003).

Esperava-se que a adesão ao TNP exercesse impacto abrangente nas relações com o Eixo Assimétrico, com o qual o Brasil se reaproximava. Essa adesão deveria ajustar a prática brasileira à política dos demais países ocidentais e contribuir para retirar ressalvas feitas por países como os Estados Unidos ao Brasil, no campo da transferência de tecnologia ${ }^{330}$. De fato, a obtenção de maiores possibilidades de cooperação com os países do Norte Global era um dos principais benefícios ensejados pelo governo Cardoso ao aderir ao TNP (CERVO, BUENO, 2011).

\footnotetext{
329 "With its 1998 decision to sign and ratify the Nuclear Non Proliferation Treaty - following Argentina's lead, whose 1994 accession to the NPT had left Brazil in an isolated and awkward positionBrasilia conformed more than ever to rule-taking status vis-à-vis a crucial dimension of the security realm. It formally accepted an inferior status vis-à-vis the five nuclear states recognized by the Treaty, and did not break the rules as did India, North Korea and Pakistan. Nothing has changed since, and it is hence indisputable that Brazil is to this day a rule-taking state when it comes to international security" (SCHENONI, ESCUDÉ, 23 mar. 2016).

330 "As dificuldades que nós tínhamos com os Estados Unidos, continuamos tendo, em vários aspectos. [...] Agora, em certos casos, ela [a posição brasileira e americana] coincidia. Por exemplo, o Brasil, ao assinar o Tratado de Não-Proliferação, o TNP [...], evidentemente estava se colocando numa posição que coincidiu... Mas não era com os Estados Unidos, era com todo o Ocidente. Com o mundo inteiro na verdade. No final, apenas os países muito marginais é que faziam parte do pequeno clube dos não assinantes do TNP, não é? Então, eu não senti nunca nenhuma resistência maior. E as pessoas que também trabalharam comigo, naturalmente, não tinham um bias ideológico, não tinham um viés ideológico antiamericano: nem os dois secretários-gerais que eu tive nem os subsecretários não tinham essa posição" (LAMPREIA, $4^{a}$ entrevista: 05.03.2008: 148).
} 
Contudo, apesar da posição oficial do governo, vale destacar, conforme sugerido por Luiz A. Moniz Bandeira (2004: 142-143), que a adesão brasileira ao TNP teria sido usada como instrumento de barganha mais abrangente da política externa brasileira, em especial no que concerne à aproximação com os Estados Unidos. Para Moniz Bandeira (2004: 142-423), ao “governo Fernando Henrique Cardoso não interessava confronto com os Estados Unidos, tanto assim que, conquanto não cedesse na questão da ALCA, anunciou a adesão do Brasil ao Tratado de Não Proliferação de Armas Nucleares (TNP) no mês seguinte à reunião de Belo Horizonte", na qual o Mercosul teria condicionado a continuidade das negociações da ALCA à abertura de Washington para negociar o "o fim das barreiras não-tarifárias aplicadas pelo país" (FERNANDES, 1997). Como a ALCA consistia tema fundamental para o Brasil e para os Estados Unidos, o qual teria exercido considerável impacto na opinião pública de ambos os países, a adesão brasileira ao TNP ter-se-ia tornado parte de uma estratégia mais abrangente de carrot and stick (incentivos e punições).

De fato, no que concerne à ALCA, o governo brasileiro conseguiu os benefícios que aventava, com o esvaziamento gradual das negociações, até seu encerramento na Cúpula de Miami (novembro, 2003). No campo nuclear, contudo, ao se analisarem os benefícios imediatos da adesão brasileira ao TNP, no campo da transferência de tecnologia nuclear ao Brasil, nota-se que os resultados não foram tão abrangentes quanto o esperado. O primeiro resultado que deveria advir da adesão ao TNP, e que fazia, historicamente, parte das reivindicações brasileiras era a retirada das proibições de exportação de urânio enriquecido e de tecnologia nuclear para o Brasil pelo governo americano $^{331}$. Essa retirada era negociada desde o governo Sarney e deveria acabar com o afastamento do Brasil dos fornecedores americanos de energia nuclear, o que ocorria desde fins do governo Médici.

Segundo análise das informações do Federal Register americano, Tlatelolco e o Quadripartite exerceram, para Brasil e Argentina, efeito similar a uma possível adesão ao TNP. Desse modo, quando esta ocorreu, já se haviam sido retiradas todas as barreiras que Washington colocava à transferência de tecnologia nuclear a Brasil e Argentina. Em

\footnotetext{
${ }^{331}$ Essas proibições deviam-se à inclusão do Brasil na lista de países potenciais proliferadores de armamentos nucleares, o que teria ocorrido na administração Nixon, em meio a esforço de fortalecimento das instituições multilaterais de não proliferação nuclear e do fracassado processo interno de privatização (vide capítulo 2).
} 
1994, imediatamente após a adesão brasileira e argentina a Tlatelolco, Washington emitiu ato regulatório ${ }^{332}$ que permitia a cidadãos e empresas americanas negociar, diretamente, com Brasil e Argentina a compra e venda de reatores nucleares ${ }^{333}$. A justificativa oficial foi, justamente, a adesão a Tlatelolco e adesão do Brasil e da Argentina ao sistema de salvaguardas da AIEA, por meio do Quadripartite.

A retirada definitiva do Brasil da lista de países com os quais os cidadãos e as empresas americanos deveriam receber autorização prévia do Secretário de Energia para negociar ${ }^{334}$ ocorreu em 18 de agosto de 1995. Essa retirada foi justificada tanto devido à entrada em vigor do Tratado de Tlatelolco ${ }^{335}$ e quanto devido à criação da $\mathrm{ABACC}$ e do Quadripartite $^{336}$. Relevante notar que, segundo a linguagem da autorização do Departamento de Energia $^{337}$, pode-se inferir que os três instrumentos firmados pelo Brasil e pela Argentina (ABACC, Quadripartite, Tlatelolco) exerceram no governo americano impacto igual às adesões argentina e sul-africana ao TNP. Isso porque o Brasil obteve o mesmo tratamento dispensado àqueles países, não obstante não ser membro deste tratado.

Além de Tlatelolco e do Quadripartite, também relevante foi a entrada do Brasil no GSN, a qual tornou o Brasil elegível para receber material radioativo, desde que respeitadas licenças gerais de exportação ${ }^{338}$. De fato, alguns meses depois, em abril de 1997, o governo americano autorizou a transferência pela Alemanha de tubos de revestimento Zircaloy-4 americanos ao Brasil, os quais seriam incorporados a

\footnotetext{
${ }^{332}$ ESTADOS UNIDOS, 29 aug. 1994

${ }^{333}$ Desde a década de 1970 , na redefinição das normas regulatórias da política nuclear americana (vide cap. 2), as negociações de empresas americanas com o Brasil deveriam ocorrer mediante análise caso por caso (case-by-case analysis) pelo Departamento de Energia (ESTADOS UNIDOS, 29 aug. 1994).

${ }_{334}$ list of countries for which specific authorization by the Secretary of Energy is required (ESTADOS UNIDOS, 18 aug. 1995)

335 "Recognize that Argentina, Brazil, and Chile in 1994 brought into force for their national territories the 1967 Treaty for the Prohibition of Nuclear Weapons in Latin America and the Caribbean (Treaty of Tlatelolco) and that Argentina and South Africa have become party to the Treaty on the NonProliferation of Nuclear Weapons (NPT) and members of the Nuclear Suppliers Group." (ESTADOS UNIDOS, 18 ago, 1995)

336 "Recognize that Argentina and Brazil have completed ratification of the Quadripartite Safeguards Agreement with the International Atomic Energy Agency [IAEA] and the Brazilian-Argentine Agency for Accounting and Control of Nuclear Materials for the application of IAEA safeguards on all of their nuclear activities, that South Africa has completed its own full-scope safeguards agreement with IAEA, and that Chile also has IAEA safeguards agreements covering its nuclear facilities." (ESTADOS UNIDOS, 18 ago, 1995)

${ }^{337}$ Vide nota anterior.

338 "Brazil, New Zealand, Republic of Korea, South Africa, and Ukraine are added as member countries of the Nuclear Suppliers Group (NSG) eligible to receive radioactive materials under certain general licenses for export" (ESTADOS UNIDOS, 18 jul.1996).
} 
equipamentos de enriquecimento de urânio para os reatores de Angra $2^{339}$ e, em outubro de 1997, o Washington autorizava a continuidade de tratativas para firmar com o Brasil tratado de cooperação no campo da energia nuclear ${ }^{340}$ - o qual será firmado em 2000 e exaltará as atitudes responsáveis do Brasil no campo da não proliferação ${ }^{341}$.

Com o Eixo Assimétrico, as relações fortaleceram-se entre 1989 e 1998 de forma ascendente. Esse eixo foi crucial para consolidar os objetivos brasileiros, os quais incluíam, na década de 1990, renovar as credenciais do pais e obter tecnologia sensível fundamental para concretizar os interesses nacionais do pais - relacionados, como lembrou Amado Cervo (1994), à concretização do vetor desenvolvimento. Dessa forma, ao ingressar no regime internacional de não proliferação o Brasil, nos governos Collor, Franco e Cardoso, dedicou esforços a manter boas relações com os países do Norte Global, em especial Alemanha - com a qual realizou intensas negociações para abandonar o Acordo de 1975 e firmar novo - e com os Estados Unidos, que deu seu beneplácito aos esforços brasileiros ao retirar as restrições que impunha a negociações no campo atômico com o Brasil, antes mesmo da adesão deste ao TNP. O interesse do Brasil em obter tecnologia do Norte Global foi, logo, confirmado e instrumentalizado, de maneiras distintos, pelos diferentes governos brasileiros na década de 1990.

\section{Conclusões Parciais}

O período entre 1990 e 1998 representou uma fase de intensas modificações na política nuclear brasileira, porquanto foi quando o país aderiu, de fato, ao regime internacional de não proliferação nuclear e eliminou as desconfianças que pairavam sobre suas pretensões. Isso foi possível, inicialmente, devido à abdicação da tese jurídico-política das explosões pacificas, que marcara o discurso nacional desde os anos 1950. Essa constância na posição foi, em grande parte, permitida devido à consolidação da democracia brasileira e à concomitante ascensão de civis às posições de gerência da política nuclear brasileira. Isso, em especifico, foi consolidado apenas no governo

\footnotetext{
${ }^{339}$ ESTADOS UNIDOS, 4 abril. 1997

${ }^{340}$ Memorandum for the Secretary of State [and] the Secretary of Energy I have considered the proposed Agreement for Cooperation between the Government of the United States of America and the Government of the Federative Republic of Brazil Concerning Peaceful Uses of Nuclear Energy, along with the views, recommendations, and statements of the interested agencies. I have determined that the performance of the agreement will promote, and will not constitute an unreasonable risk to, the common defense and security. Pursuant to section 123 b. of the Atomic Energy Act of 1954, as amended (42 U.S.C. 2153(b)), I hereby approve the proposed agreement and authorize you to arrange for its execution." (ESTADOS UNIDOS, 21 out. 1997)

${ }^{341}$ ESTADOS UNIDOS, 12 out. 2000
} 
Cardoso, com a criação do Ministério da Defesa, que colocou um civil sob a gestão final do Projeto Remo de desenvolvimento de submarino de propulsão nuclear.

Outro fator fundamental a definir a aproximação do Brasil com o regime internacional de não proliferação nuclear foi a prerrogativa dos governos Collor, Franco e Cardoso de adaptar, cada um a seu modo, a política externa brasileira ao novo momentum internacional, marcado pela globalização, pela ascensão de novos temas, como o meio ambiente, pela emergência de novos atores da sociedade civil. Nesse contexto, conciliaram-se na década de 1990 três ambições do Brasil: (1) desenvolver tecnologia nuclear de maneira autóctone (herança do programa paralelo, na década de 1980), (2) obter transferência de tecnologia do Eixo Assimétrico , (3) manter sistema regional pacífico e seguro, livre de ameaças nucleares externas.

Nesse processo, as relações bilaterais da política nuclear exerceram papel crucial. Apesar de o Eixo Sul ter sido reduzido à quase insignificância, tanto devido à opção dos governos democráticos, sob o paradigma do Estado normal ou do modelo da integração competitiva, optaram por privilegiar as relações com o Norte Global, em detrimento daquelas com o Sul, quanto devido à crescente busca pela transparência do programa nuclear brasileiro, os demais eixos foram demasiadamente dinâmicos. Atenção especial merece ser dada ao Eixo Regional, no qual se consolidou, na área nuclear, cooperação estratégica efetiva.

Isso foi possível devido, em primeiro lugar, devido à coincidência programática e de objetivos externos entre os governos na Casa Rosada e no Palácio do Planalto (e.g. inserção na comunidade internacional, aproximação com os regimes internacionais vigentes, obter tecnologia dos países do Norte) e, em segundo, devido à superação completa da rivalidade e das desconfianças mútuas, processo esse em andamento desde o governo Figueiredo e da Guerra das Malvinas. A cooperação estratégica formada no campo nuclear foi operacionalizada com a criação do sistema ABACC-Quadripartite, o qual foi arcabouço inovador e inédito, não obstante ter recebido influências de outras três propostas de modelo anteriores (Proposta Findley, Plano Alfonsín, Modelo EURATOM). O arcabouço ABACC-Quadripartite permitiu ao Brasil e à Argentina ingressar, de modo inusitado, no regime internacional de não proliferação nuclear e possibilitou acesso a esses países normalizar as relações no campo nuclear com os Estados Unidos. 
Com o Eixo Assimétrico, as relações adquiriram nova vitalidade, após afastamento e desilusão verificados entre 1979 e 1989. Essa reaproximação foi ensejada pela própria ambição dos três governos que se sucederam na Presidência da República de aproximar o Brasil dos centros de poder mundial e, assim, obter insumos para o desenvolvimento, o vetor principal da inserção internacional do país. Com essa justificativa, e com certo consenso interno (em especial na Presidência e no Itamaraty), o Brasil aderiu ao TNP, não obstante ter sido essa atitude pouco significativa no momento em que foi realizada, na medida em que as garantias feitas pelo Brasil por meio do sistema AIEAQuadripartite e da retirada das reservadas ao Tratado de Tlatelolco já se haviam mostrado suficientes para inserir o Brasil nas instituições do regime de não proliferação nuclear - inclusive com a inclusão do Brasil no GSN. Essa menor significação pode ser, inclusive, corroborada com a suspeita de que a adesão foi utilizada como instrumento de compensação aos Estados Unidos devido às dificuldades postas nas negociações com a ALCA. 


\section{Conclusão}

Entre o repúdio oficial à adesão ao TNP, em 1969, e o ingresso brasileiro àquele tratado, em 1998, o Brasil desenvolveu processo oscilante de aproximação e de recuo com o regime internacional de não proliferação nuclear. Nesse período, o Brasil, o passou por três momentos de definição da política nuclear nacional, os quais se pautaram por distintas estratégias de obtenção de tecnologia nuclear. Nesses três momentos, verificaram-se, respectivamente, entre 1969 e 1978, a tentativa de aproximação com aquele regime, nos governos Médici e Geisel, porém com ênfase no repúdio completo à adesão ao TNP; entre 1979 e 1989, o afastamento do regime, com os desenvolvimentos do programa autônomo e a aproximação pontual ensejada com os países do Eixo Sul; entre 1990 e 1998, a reaproximação e adesão gradual ao regime, facilitado pela consolidação do regime democrático, pela conformação de cooperação estratégica com a Argentina e pela renovação do interesse em obter tecnologia sensível dos países do Eixo Assimétrico.

Esse processo, como afirmado anteriormente, não se confunde com um caminho natural a ser trilhado por países como o Brasil, mas se tratou de um processo único de inter-relação entre as perspectivas brasileira de mundo e a evolução das instituições do regime internacional de não proliferação de armas nucleares. De fato, como verificado ao longo dos capítulos 2 a 4, o próprio regime internacional de não proliferação de armas nucleares modificou-se constantemente ao longo das décadas analisadas, em consonância com a mudança das normas internas de atores como os Estados Unidos, em especial nos governos Nixon e Ford; com a mudança das instituições internacionais, por meio da criação de regras mais claras e eficientes para a venda e compra de urânio; e com a criação de instituições regionais para conter a obtenção de armas nucleares por países latino-americanos (e.g. ABACC-Quadripartite).

\section{Como se conformou o processo de adaptação da política nuclear brasileira ao} regime internacional de não proliferação nuclear? Essa questão, colocada inicialmente, foi fruto de discussão ampla durante os quatro capítulos anteriores. Apesar de o Brasil ter mantido, entre 1969 e 1998, as mesmas diretrizes no discurso oficial, as quais se relacionaram intimamente com os principais basilares do apanhado histórico da política externa brasileira (juridicismo, pacifismo e pragmatismo) e com a busca do desenvolvimento, a prática da definição da política nuclear brasileira mostrou-se 
oscilante. Isso se deveu ao recuo observado, entre 1979 e 1989, no processo de adaptação do Brasil ao regime internacional de não proliferação nuclear, o qual foi fruto último da desilusão identificada nas relações com o Eixo Assimétrico.

Essa desilusão foi resultado imediato do afastamento das grandes potências internacionais verificado desde fins do governo Geisel e caracterizado pela intensificação das pressões americanas contra o programa nuclear brasileiro, pela inviabilidade comercial do método de jato centrífugo, cuja transferência fora negociada com a Alemanha Federal, e pelo insucesso das negociações com o Reino Unido e com a Holanda para obter urânio enriquecido e, possivelmente, tecnologia de enriquecimento da URENCO. Ao passo que no segundo momento as relações com o Eixo Assimétrico foram turbulentas, no primeiro momento, identificou-se tensão nas relações com o Eixo Regional, marcado pelo conflito das cataratas e pela desconfiança de Brasília em relação às pretensões do programa nuclear argentino, particularmente durante o governo de Juan Perón.

O segundo momento foi, portanto, fruto de mudanças verificadas nos rumos da estratégia delineada no primeiro momento, quando se optou pela implementação concomitante de usinas de tecnologia hidrelétrica e nuclear no parque energético brasileiro, de modo a garantir o crescimento futuro ensejado pelos três PNDs. Essa mudança de rumos, instada, principalmente, por fatores exógenos, como os Choques do Petróleo de 1973 e de 1979, e pela desilusão com os países do Eixo Assimétrico levou ao controle da política nuclear brasileira grupos internos aqui denominados de autonomista belicistas, os quais passaram a antever a necessidade de o Brasil desenvolver tecnologia nuclear para fins múltiplos. Esses grupos focaram-se, principalmente, nos rumos do Projeto Solimões, o qual tinha como uma de suas metas desenvolver e testar explosivos nucleares para fins pacíficos. A tese jurídico-política das explosões pacíficas foi marca indelével da política oficial brasileira desde os anos 1950 e relacionava-se com o ímpeto da diplomacia nacional de obter quaisquer insumos que pudessem ser necessários para concretizar o desenvolvimento nacional.

Em consonância com esse objetivo, o Brasil buscou aproximação única, no campo nuclear, com países do Eixo Sul, com os quais se matinha identidade comum relativa ao pertencimento à periferia do sistema internacional. Com esses países, ocorreu aproximação em duas formas. A primeira foram as tratativas sigilosas, empreendidas com China e África do Sul (a primeira exitosa e a segunda não levada a diante pelo Brasil). Esses países mostraram-se como alternativas para a obtenção de insumos 
necessários à condução do programa paralelo, como urânio enriquecido. A segunda forma de tratativas abarca aquelas realizadas de modo ostensivo, com o objetivo de viabilizar comercialmente a tecnologia nuclear em desenvolvimento no Brasil em parceria com a Alemanha, no caso da busca do mercado mexicano, e de obter maior aproximação com o principal fornecedor de petróleo ao Brasil, o Iraque. Também fundamental nesse período foi a aproximação progressiva com o Eixo Regional, o que ocorreu no período de colapso da ditadura militar argentina, com a crise de Beagle e a Guerra das Malvinas.

Não obstante sinais de mudança já terem sido verificados no governo Sarney, com a ascensão interna de atores relevantes como o Parlamento (Assembleia Nacional Constituinte), a ruptura na política nuclear ocorreu apenas com o governo Collor, o primeiro eleito diretamente, portanto menos dependente do acordo de transição realizado com os militares Nesse período, foi descontinuado, de modo definitivo, o programa paralelo, apesar de terem sido mantidos alguns elementos desenvolvidos programa paralelo, como o reconhecimento de que esse conseguiu formar as condições necessárias para obter tecnologia de enriquecimento de urânio e como o programa de desenvolvimento de mini-reatores para propulsão de submarinos, o antigo Projeto Remo.

A descontinuidade do Programa Paralelo insere-se na proposta de atualização da política externa brasileira ao novo momentum internacional, o que se baseou na indicação à comunidade internacional de que o governo democrático brasileiro era transparente e possuía interesse em aderir às instituições internacionais vigentes. Essa adaptação ao regime internacional ocorreu de modo gradual, porém rápido, ao longo dos governos Collor, Franco e Cardoso e somente foi possível devido à concretização de condições externas favoráveis, caracterizadas pela aproximação com o Eixo Regional formação de uma verdadeira zona de paz na América do Sul - e pelo retorno do interesse no Eixo Assimétrico. De fato, a aproximação com o Regime Internacional de Não Proliferação Nuclear ocorreu em consonância e em parceria com a Argentina, a qual adquiriu relevância considerável nas relações externas da Nova República brasileira.

Essa aproximação realizou-se, inicialmente, com a criação do sistema ABACCQuadripartite, o qual permitiu ao Brasil e à Argentina ingressar no aparato de salvaguardas abrangentes da AIEA sem, contudo, aderir ao TNP. Esse processo foi acompanhado com a retirada das ressalvas feitas ao Tratado de Tlatelolco, o que 
significou o abandono definitivo da tese das explosões pacíficas. Essas duas atitudes, mais tarde acrescidas da adesão brasileira ao MTCR, ao GSN, ao CTBT, permitiram ao Brasil criar condições necessárias para aderir ao regime internacional de não proliferação nuclear, o que é corroborado pela retirada do Brasil da lista de países com relação aos quais cidadãos e empresas americanos eram restritos.

A adesão ao TNP, ocorrida em 1998, após a conclusão daquele processo de adesão às demais instituições do regime internacional de não proliferação, foi o ponto culminante da estratégia brasileira de ingresso naquele regime. Embora os benefícios da adesão não se tenham mostrado claros, a leitura feita pelos tomadores de decisão era a de que o não ingresso naquele regime era inócuo e colocava o país em posição indesejável, pois o unia a um grupo de países considerados páreas no tema, como a Índia e o Paquistão. Criou-se, então, entre as elites de tomadores de decisão no poder, consenso interno quando à necessidade de adesão àquele tratado. A adesão foi, porém, feita, de modo rápido e controverso.

A análise feita dos desenvolvimentos da política nuclear brasileira em três momentos e por meio de três eixos revelou a importância das relações bilaterais no processo de ingresso do Brasil ao regime internacional de não proliferação nuclear. Embora as interconexões entre os âmbitos políticos doméstico e internacional sejam abrangentes, a ponto de se tornarem, em certos casos, indissociáveis, as relações entre essas esferas mostraram-se, na política nuclear brasileira, mutuamente relevantes. De fato, como se aqui argumentou, a adesão brasileira ao regime internacional de não proliferação nuclear é processo que adveio não apenas da conjuntura doméstica, mas também do interesse brasileiro em obter tecnologia do Norte Global e da aproximação com a Argentina. Essas duas variáveis indicam, destarte, a crucialidade da cooperação internacional para a definição da política nuclear brasileira, em especial entre 1969 e 1998, quando se consolidaram as linhas de atuação do Brasil no campo da energia atômica. 


\section{Bibliografia}

\section{Bibliografia Secundária}

ALDEN, C.; MORPHET, S.; VIEIRA, M. The South in World Politics. 2010 ed. New York: Palgrave Macmillan, 2010.

ALEXANDRE, Cristina Vieira (2007), O Papel do Poder Legislativo na Política Exterior Brasileira: o Caso dos Acordos Referentes ao Centro de Lançamentos de Alcântara (CLA). Trabalho apresentado ao $1^{\circ}$ Encontro Nacional da Associação Brasileira de Relações Internacionais, Brasília, DF.

ANDREWS, W. G.; HOFFMANN, S. The Fifth Republic at Twenty. New York: SUNY Press, 1980.

ARBILLA, J. M. (2000), Arranjos institucionais e Mudança Conceitual nas Políticas Externas Argentina e Brasileira (1989-1994), Estudos Históricos, v.8, n.15

ARQUILlA, J.; RONFELDT, D. Networks and Netwars: The Future of Terror, Crime, and Militancy. Santa Monica, CA: RAND Corporation, 2001.

BACH, D. La Politique extérieure de Valéry Giscard d'Estaing. Paris: Presses de la Fondation Nat. des Sciences Politiques, 1985.

BANDARRA, L. C. Não-Proliferação Nuclear e Epistemologias Geoculturais: uma abordagem do debate teórico entre as teorias hegemônicas e os casos brasileiro e indiano. Revista de Estudos Internacionais, Vol. 7, No 1, 2016. P. 98-118

BARLETTA, M. The Military Nuclear Program in Brazil. Center for International Security and Arms Control Working Paper. Stanford: Stanford University, ago. 1997 Disponível em: <http://www-leland.stanford.edu/group/CISAC/>, acessado em $28 / 05 / 2016$

BHAVNAGRI, N.P. The Global Village. Childhood Education. V. 77 No. 2001.p. 256. 
BOWEN, W. Q. Brazil's Accession to the MTCR. The Nonproliferation Review, Spring-Summer, p. 86-91, 1996.

BRENNER, M. Nuclear Power and Non-Proliferation: The Remarking of U.S. Policy. Cambridge: Cambridge University Press, 2009.

CARNEIRO, D. D. Crise e esperança: 1974-1980. In: ABREU, M. P. (Org.). A Ordem do Progresso: cem anos de política econômica republicana 1889-1989. Rio de Janeiro: Editora Campus, 1995. p. 445.

CARNEIRO, D. D.; MODIANO, E. Ajuste Externo e Desequilíbrio Interno: 19801984. In: ABREU, M. P. (Org). . A Ordem do Progresso: cem anos de política econômica republicana 1889-1989. Rio de Janeiro: Editora Campus, 1995. p. 445.

CASARÕES, G. S. P. E. O Papel do Itamaraty na Definição da Política Externa do Governo Collor de Mello. Revista Brasileira de Política Internacional, v. 55, n. 1, p. 135-153, 2012.

CAStro SAnTOS, M. H. Política e Políticas de uma Energia Alternativa: o Caso do Proálcool. Rio de Janeiro: Editora Notrya/ANPOCS, 1993.

CERVO, A. L. Inserção Internacional: formação dos conceitos brasileiros. 3. ed. São Paulo: Saraiva, 2009.

CERVO, A. L. O Desafio Internacional: a política exterior do Brasil de 1930 a nossos dias. CERVO A. L. (org.). Brasília: Editora UnB, 1994,

CERVO, A. L.; BUENO, C. História da Política Exterior do Brasil. Edição: 4ª, Revista e Ampliada ed. Brasília, DF: UNB, 2011.

CERVO, A. L.; LESSA, A. C. O declínio: inserção internacional do Brasil (2011-2014). Revista Brasileira de Política Internacional, v. 57, n. 2, p. 133-151, 2014.

CÔRTES, O. H. D. A Política Externa do Governo Sarney: o início da reformulação de diretrizes para a inserção internacional do Brasil sob o signo da democracia. 1. ed. Brasilia: Funag, 2010. 
DADOS, N.; CONNELL, R. The Global South. Contexts, v. 11, n. 1, p. 12-13, 1 fev. 2012.

DAWOOD, L.; HERZ, M. Nuclear governance in Latin America. Contexto Internacional, v. 35, n. 2, p. 497-535, 2013.

DE TITTO, R. La Joya más Apreciada. 1. ed. Buenos Aires: El Ateneo, 2008.

DUROSELlE, J.-B. Todo Império Perecerá. Traduç qo Ane Lize Spaltemberg de S. Magalhães. Editora Universidade de Brasília ed. Brasília: 2000.

ESCUDÉ, C. La Argentina, ¿un parásito en el mundo?: Ciclos de vaciamiento, clase política delictiva y política exterior en un "Estado parasitario". Buenos Aires: Editoral Lumiere, 2005.

FAORO, R. Os donos do poder: Formacao do patronato politico brasileiro. 3a. ed., rev edition ed. São Paulo, SP: Editora Globo, 2001.

FARES, S. T. O Pragmatismo do Petróleo: as relações entre o Brasil e o Iraque. Revista Brasileira de Política Internacional, v. 50, n. 2, p. 129-145, dez. 2007.

FARES, S. T. O Pragmatismo do Petróleo: as relações entre o Brasil e o Iraque, de 1973 a 2007. Dissertação de Mestrado_Brasília, DF: Instituto de Ciência Política e Relações Internacionais da Universidade de Brasília, 2007b.

FAUSTO, B. Historia do Brasil. 14. ed. São Paulo, SP, Brasil: Didática, 2012.

FONSECA JR, G. A legitimidade e outras questões internacionais. 2. ed. São Paulo: Paz e Terra, 1998.

GALL, Norman. Atoms for Brazil, dangers for all. Foreign Policy, No. 23, June, 1976

GARCIA, E. V. O pensamento dos militares em política internacional (1961-1989). Revista Brasileira de Política Internacional, v. 40, n. 1, p. 18-40, jun. 1997.

GARDINI, G. L. Towards modular regionalism: the proliferation of Latin American cooperation. Revista Brasileira de Política Internacional., v. 58, n. 1, p. 210-229, 2015 . 
GEHRE, T. A Política Externa Brasileira Durante Os Governos Militares: Idéias, Práticas E Imagens (1964 1984). Textos e Debates, v. 2, n. 15, 20 abr. 2012.

GILPIN, R. Global Political Economy. Understanding the international economic order. New Heaven: Princeton University Press, 2001.

GOFFREDO JR, G. S. DE. Entre Poder e Direito: a tradição grotiana na política externa brasileira. Brasilia: Funag, 2005.

GRAY, C. S. War, Peace and International Relations: An introduction to strategic history. 2 edition ed. Abingdon, UK : New York: Routledge, 2011.

GROSS ESPIELL, H. La signature du traité de Tlatelolco par la France et la Chine. Annuaire français de droit international, vol. 19, 1973. pp. 131-146.

HARNISCH, S. Das Proliferationsnetzwerk um A. Q. Kahn. Politik und Zeitgeschichte, n. 48, p. 24-31, 2005.

HELlmann, G.; BAUMnAnN, R.; WAGNER, W. Deutscher Außenpolitik: Eine Einführung. Wiesbaden: VS Verlag für Sozialwissenschaften, 2006.

HIRST, M. Brasil-Estados Unidos: desencontros e afinidades. Edição: 1 ed. Rio de Janeiro: Editora FGV, 2009.

HIRST, M.; PINHEIRO, L. A política externa do Brasil em dois tempos. Revista Brasileira de Política Internacional, v. 38, n. 1, p. 5-23, 1995.

HUNTER, W. Eroding Military Influence in Brazil: Politicians against Soldiers. Chapel Hill and London: The University of North Carolina Press, 1997.

HURRELL, A. J. The Quest For Autonomy: the evolution of brazil's role in the international system, 1964 - 1985. Brasília: Funag, 2013.

JARDIM, C. A. Understanding the concept of Global South: an initial framework. Boletim Mundorama, 11 nov. 2015. 
JASPER, J. Gods, Titans and mortals: Patterns of state involvement in nuclear development. Energy Policy, v. 20, n. 7, p. 653-659, 1992.

JOHNSON, P. A History of the American People. 1 edition ed. New York, NY: Harper Perennial, 1998.

KISSINGER, H. Diplomacy. Reprint edition ed. New York: Simon \& Schuster, 1995.

KISSINGER, H. Nuclear Weapons \& Foreign Policy. Abridged edition ed. New York: W. W. Norton \& Company, 1969.

KOLlMANN, T. Nuclear Madness: What was Special About the Brazil-Germany Nuclear Accord of 1975?. In: Third Annual Cold War History Research Center International Student Conference. Budapest: 10 jul. 2012

KRASNER, S. D. Structural Causes and Regime Consequences: Regimes as Intervening Variables. International Organization, v. 36, n. 2, p. 185-205, 1982.

KRAUSE, J. German Nuclear Export Policy and the Proliferation of Nuclear Weapons - Another Sonderweg? (Aspen Institute, Berlin and the Nonproliferation, Policy Education Center, Eds.). In: Germany and Nuclear Nonproliferation. Washington: 2005

LAFER, C. A identidade internacional do Brasil e a política externa brasileira: passado, presente e futuro. 2. ed. São Paulo: Editora Perspectiva, 2004.

LESSA, A. C. M. A vertente perturbadora da política externa durante o governo Geisel: um estudo das relações Brasil-EUA (1974-1979). Revista de Informação Legislativa, p. 69-82, jan. 1998.

LESSA, A. C. M. Hélio Jaguaribe: a geração do nacional-desenvolvimentismo. In: PIMENTEL, J. V. DE S. (Ed.). . Pensamento Diplomático Brasileiro: formuladores e agemtes da política exterma (1750-1950). Brasília: Funag, 2013. v. 3p. 1135.

LESSA, A. C. Uma parceria em construção: as relações entre a França e o Brasil, 1945-2000. 1. ed. Belo Horizonte: Fino Traço, 2013. 
LESSA, R. A Invenção Republicana: Campos Sales, As Bases E A Decadencia Da Primeira Republica Brasileira. Rio de Janeiro e São Paulo: Vertice, 1988.

LIMA, M. R. The Political Economy of Brazilian Foreign Policy: Nuclear Energy, Trade and Itaipu. Brasília: Funag, 2013.

LÓPES-ALVES, F. The Latin American nation-state and politics. In: TICKNER, A. B.; BLANEY, D. L. (Eds.). . Thinking International Relations Differently. [s.l.] Routledge, 2013.

MALLEA, R. La cuestión nuclear en la relación argentino-brasileña (1968-1984). Dissertação de Mestrado-Rio de Janeiro: Universidade do Estado do Rio de Janeiro, 2012 .

MALLEA, R.; SPEKTOR, M.. Introduction. In.: MALLEA, R.; SPEKTOR, M.; WHEELER, N. Origens da Cooperação Nuclear: uma história oral crítica entre Argentina e Brasil. 1. ed. Washington e Rio de Janeiro: Woodrow Wilson International Center for Scholars and FGV, 2015.

MARTIN, Lisa. Democratic Commitments: Legislatures and International Cooperation. Princeton, Princeton University Press, 2000.

MONIZ BANDEIRA, L. A. As Relações Perigosas. Brasil-Estados Unidos. Rio de Janeiro: Civilização Brasileira, 2004.

MONIZ BANDEIRA, L. A. Brasil-Estados Unidos. A Rivalidade Emergente. Rio de Janeiro: Civilização Brasileira, 1989.

MONIZ BANDEIRA, L. A. Wachstumsmarket Brasilien: der deutsche Wirtschaftsund Handelsbeitrag in Geschichte und Gegenwart. Wiesbaden: Springer Fachmedien, 2013.

MORALES, M. J. Malvinas: la guerra de los neutrales. 2. ed. Buenos Aires: Continente, 2012. 
NEDAL, D. K. Brazilian Nuclear Cooperation with the People's Republic of China | Wilson Center. Disponível em: <http://www.wilsoncenter.org/publication/braziliannuclear-cooperation-the-peoples-republic-china>. Acesso em: 14 mar. 2015.

NEUMANN, I. Claiming the early state for the relational turn: the case of Rus' (ca 8001100). In: TICKNER, A.; BLANEY, D. (Eds.). . Claiming the International. 1. ed. New York: Routledge, [s.d.]. p. 78-97.

NEVES, A. A. C. (2003). O Papel do Poder Legislativo nas Negociações do Mercosul e da ALCA, in Cena Internacional, ano 5, n. 3.

NYE, J. S. The Future of Power. Reprint edition ed. New York: PublicAffairs, 2011.

O’DONNELL, G. Challenges to Democratization in Brazil. World Policy Journal, v. 5, n. 2, p. 281-300, Abril 1988.

PATTI, C. La scelta nucleare come reazione brasiliana allo shock petrolifero del 1973. Il Politico: Rivista italiana di scienze politiche, n. LXXVIII, p. 170-193, 2013.

PATTI, C. O programa nuclear brasileiro entre passado e futuro. Boletim Meridiano 47, v. 14, n. 140, p. 49-55, 19 dez. 2013 a.

PATTI, C. Apresentação. IN.: PATTI, C. (ED.). O programa nuclear brasileiro: uma história oral. Rio de Janeiro: Editora FGV, 2014.

PATTI, C. The origins of the Brazilian nuclear programme, 1951-1955. Cold War Studies, Vo. 1, 2014a.

PATTI, C. O programa nuclear brasileiro: uma história oral. [s.l.] Editora FGV, $2014 b$.

PECEQUILO, C. S. A Política Externa dos Estados Unidos: Continuidade ou Mudança? 2. ed. Porto Alegre: Ed. UFRGS, 2005.

PECEQUILO, C. S. As relações Brasil-Estados Unidos. 1. ed. Belo Horizonte: Fino Traço, 2012. 
PENNA FILHO, P. A parceria africana: as relações Brasil-África do Sul. 1. ed. Belo Horizonte: Fino Traço, 2013.

PINHEIRO, L. Política externa brasileira (1889-2002). Rio de Janeiro: Zahar, 2004.

PINHEIRO, L. Traídos pelo Desejo: Um Ensaio sobre a Teoria e a Prática da Política Externa Brasileira Contemporânea. Contexto Internacional, v. 22, n. 2, p. 305-335, 2000.

RAPOPORT, M.; SPIGUEL, C. Política Exterior Argentina: Poder y Conflictos Internos (1880-2001). Buenos Aires: Capital Intelectual S A, 2005.

REDRICK, J. R. Regional nuclear arms control in Latin America. International Organization, v. 29, n. 02, p. 415-445, mar. 1975.

RESENDE, Carlos A. R. Política Externa Independente: as relações com os Estados Unidos na busca por autonomia. Dissertação de mestrado apresentada ao Instituto de Relações Internacionais da Universidade de Brasília, 2009.

RICÚPERO, R. O Brasil, a América Latina e os EUA desde 1930: 60 anos de uma relação triangular. IN.: ALBUQUERQUE, J. A. G.; SEITENFUS, R.; CASTRO, S. H. N. DE L. J. (Orgs.). Sessenta anos de política externa brasileira (1930-1990). 2. ed. São Paulo, SP: Cultura Editores Associados : Núcleo de Pesquisa em Relações Internacionais da USP, 2006.

RICUPERO, R. Visões do Brasil: Ensaios sobre a historia e a inserção internacional do Brasil. Rio de Janeiro: Editora Record, 1995.

ROMERO, L. A. A History of Argentina in the Twentieth Century. University Park: The Pennsylvania State University Pres, 2002.

ROSA, M. C. Sociologies of the South and the actor-network-theory Possible convergences for an ontoformative sociology. European Journal of Social Theory, p. 1-18, 5 nov. 2015.

ROSECRANCE, R. The Rise of the Trading State: Commerce and Conquest in the Modern World. New York: Basic Books, 1986. 
SALLUM JR, B. Governo Collor: O Reformismo Liberal e a Nova Orientação da Política Externa Brasileira. Dados, v. 54, n. 2, p. 259-288, 2011.

SARAIVA, J. F. S. . Dois gigantes e um condomínio: da guerra fria à coexistência pacífica (1947-1968). In: SARAIVA, J. F. S. . (Ed.). . História das Relações Internacionais Contemporâneas. 2. ed. São Paulo: Saraiva, 2010a. v. 1.

SARAIVA, J. F. S. . Détente, diversidade, intranquilidade e ilusões igualitárias (19691979). In: SARAIVA, J. F. S. . (Ed.). . História das Relações Internacionais Contemporâneas. 2. ed. São Paulo: Saraiva, 2010b. v. 1.

SARAIVA, J. F. S. Autonomy in Brazil's international insertion: its own historical way. Contexto Internacional, v. 36, n. 1, p. 9-41, jun. 2014.

SARAIVA, M. G. Encontros e desencontros: o lugar da Argentina na política externa brasileira. 1. ed. Belo Horizonte: Fino Traço, 2012.

SARAIVA, M. G. Encontros e desencontros: perspectivas de uma parceria estratégica. In.: LESSA, A. C.; OLIVEIRA, H. A. (orgs.). Parcerias estratégicas do Brasil: Os significados e as experiências tradicionais. Belo Horizonte: Editora Fino Traço, 2013, 1. ed. Volume 1. P.219-237

SARDENBERG, R. M. João Augusto de Araújo Castro: diplomata. In: PIMENTEL, J. V. DE S. (Ed.). . Pensamento Diplomático Brasileiro: formuladores e agemtes da política exterma (1750-1950). Brasília: Funag, 2013. v. 3p. 1135.

SATO, E. A agenda internacional depois da Guerra Fria: novos temas e novas percepções. Revista Brasileira de Política Internacional, v. 43, n. 1, p. 138-169, 2000 .

SATO, E. Almirante Álvaro Alberto: a busca do desenvolvimento científico e tecnológico nacional. In: PIMENTEL, J. V. DE S. (Ed.). . Pensamento Diplomático Brasileiro: formuladores e agemtes da política exterma (1750-1950). 1. ed. Brasilia: Funag, 2013. v. 3p. 1135.

SCHENONI, L.; ESCUDÉ, L. Peripheral Realism Revisited. Rev. Bras. Polít. Int. Vol. 59, No 1, 2016. 
SEABORG, G. T. A Scientist Speaks Out: A Personal Perspective on Science, Society and Change. Hackensack, New Jersey: World Scientific, 1996.

SIMMONS, B. A.; MARTIN, L. International Organizations and Institutions. In: WALTER, C.; RIESSE, T.; SIMMONS, B. A. (Orgs.). . Handbook of International Relations. London: Sage, 2007. p. 192-210.

SKIDMORE, T. The Politics of Military Rule in Brazil, 1964-1985. New York: Oxford University Press, 1990.

SPEKTOR, M. Origens e direção do Pragmatismo Ecumênico e Responsável (19741979). Revista Brasileira de Política Internacional, v. 47, n. 2, p. 191-222, dez. 2004.

SPEKTOR, M. Ruptura e Legado: o colapso da cordialidade oficial e a construção da parceria entre o Brasil e a Argentina (1967-1979). Dissertação de MestradoBrasília: Instituto de Ciência Política e Relações Internacionais da Universidade de Brasília, 2002.

SPEKTOR, M. The Long View: How Argentina and Brazil Stepped Back from a Nuclear Race | Americas Quarterly. The Amazon Today, 2015.

STUENKEL, O. (2014) India-Brazil-South Africa Dialogue Forum (IBSA): The Rise of the Global South? London: Routledge. 174p.

TELLIS, A. J. No Escape: Managing the Enduring Reality of Nuclear Weapons. In.: TELliS, A. J.; DENMARK, A. M.; TANNER, T. (Orgs.). Ásia in the Second Nuclear Age. Strategic Ásia, 2013-2014

TICKNER, A. B. Hearing Latin American Voices in International Relations Studies. International Studies Perspectives, v. 4, n. 4, p. 325-350, 1 nov. 2003.

TRAUMANN, A. P. No Meio do Fogo Cruzado: a participação do Brasil no conflito Irã-Iraque. Revista Litteris, n. 7, 2011.

VARGAS, E. V. Átomos na integração: a aproximação Brasil-Argentina no campo nuclear e a construção do Mercosul. Revista Brasileira de Política Internacional, v. 40, n. 1, jun. 1997, p. 41-74. 
VARGAS, J. Campanha permanente: a construção do substrato normativo da busca do Brasil por uma reforma do Conselho de Segurança das Nações Unidas. Dissertação de mestrado apresentada ao Programa de Pós-Graduação em Relações Internacionais da Universidade de Brasília, Brasília: 2008.

VELÁZQUEZ, A. C. S. Civil-Military Affairs and Security Institutions in the Southern Cone: The Sources of Argentine-Brazilian Nuclear Cooperation. Latin American Politics and Society, v. 46, n. 4, p. 29-60, 1 dez. 2004.

VIGEVANI, T.; OLIVEIRA, M. F. DE; CINTRA, R. Política externa no período FHC: a busca de autonomia pela integração. Tempo Social, v. 15, n. 2, p. 31-61, nov. 2003.

VIZENTINI, P. F. A política externa do regime militar brasileiro. 1. ed. Porto Alegre: Ed. UFRGS, 1998. v. 1

VON BREDOW, W. Die Außenpolitik der Bundesrepublick Deutschland: Eine Einführung. Wiesbaden: VS Verlag für Sozialwissenschaften, 2006.

WAEVER, O. (1997) Figures of international thought: introducing persons instead of paradigms. In: WAEVER, O. (Org.). . The Future of International Relations. New York \& London: Routledge.

WROBEL, P. A Questão Nuclear nas Relações Brasil-Estados Unidos. Dissertação de Mestrado—-Rio de Janeiro: IUPERJ, 1986.

WROBEL, P. S.; REDRICK, J. R. Nuclear Cooperation in South America: The Role of Scientists in the Argentine-Brazilian Rapprochement. Annals of the New York Academy of Sciences, v. 866, n. 1, p. 165-181, 1 dez. 1998.

ZHENQIANG, P. Nuclear Nonproliferation - Past, present and future, Publications, China Office. Konrad-Adenauer-Stiftung. Retrieved March 16, 2015, from http://www.kas.de/china/en/publications/5339/, 2004. Acessado em 30/05/2016. 


\subsection{Artigos de Jornais e Revistas}

BERGER, J. J. Carter \& the Plutonium Economy. The Nation, v. 224, n. 4, p. 101-101, 29 jan. 1977.

BONILLA, A. El cierre de URAMEX: Un paso más en la dependencia de México. El Día, 8 jan. 1985.

CARVALHO, J. M. DE. Imperador republicano: O governo de D. Pedro II, quem diria, já fazia referências ao novo regime. Revista de História da Biblioteca Nacional, p. 12, 13 jan. 2011.

COOK, S. Don't Fear a Nuclear Arms Race in the Middle East. Foreign Policy, 2012.

DURAZZO, M. História do Combustível Nuclear no IPEN. Sem data. Disponível em: 〈https://www.ipen.br/portal_por/portal/interna.php?secao_id=549>. Acesso em: 19 abr. 2016.

ENERGY POLICY. Communications on Energy: the nuclear export policy of the Reagan administration. Energy Policy, p. 168-172, jun. 1983.

FERNANDES, D. Reunião da Alca termina com consenso condicional. Folha de S.Paulo, 18 abr. 1997.

FOLHA. Universidade herda projeto do Exército. Folha de S.Paulo, 6 maio 1997. Disponível em: <http://www1.folha.uol.com.br/fsp/brasil/fc050631.htm http://www1.folha.uol.com.br/fsp/brasil/fc050631.htm>, acessado em 17/04/2016

FOLHA. Serra do Cachimbo pode ser local de provas nucleares. Folha de São Paulo, 08 ago. $1986 . \quad$ Disponível em: $<$ http://digitalarchive.wilsoncenter.org/document/117522>. Acessado em 18 de abril de 2016.

G1. Maior acidente radiológico do mundo completa 25 anos nesta semana - notícias em Goiás. G1 Notícias. 19 set. 2012. Disponível em: <http://g1.globo.com/goias/noticia/2012/09/maior-acidente-radiologico-do-mundocompleta-25-anos-nesta-semana.html>. Acesso em: 11 maio. 2016. 
GORCZESKI, V. Os segredos da paz no Cone Sul: documentos revelam como os Estados Unidos pressionaram o Brasil e a Argentina a fazer um pacto de cooperação nuclear, que inspira hoje o acordo entre Obama e o Irã. Época, 24 ago. 2015.

GUIMARÃES, L. S. Salvaguardas nucleares e o caso especial de Brasil e Argentina. OperaMundi, Rio de Janeiro: 13 fev. 2011. Disponível em: $<$ http://operamundi.uol.com.br/conteudo/opiniao/17083/salvaguardas+nucleares+e+o+c aso+especial+de+brasil+e+argentina.shtml>, acessado em 02/05/2016.

JB. Goldemberg manifesta preocupação com a usina nuclear Angra I". Jornal do Brasil, $1^{\circ}$ caderno, sábado, 19-01-85, p. 18. Disponível em Pasta "Politica energética sem data 8 docs "CTN 1984.03.00 a pasta VI, CPDOC-FGV, Rio de Janeiro.

LEALI, F.; MALTCHIK, R. Documentos apontam corrida nuclear na América Latina durante a ditadura. O Globo, 23 mar. 2014.

MARIN, D. C. País quer ser fornecedor de urânio enriquecido. O Estado de São Paulo. São Paulo. Retrieved March 14, 2015, from http://www.sae.gov.br/site/?p=3128, 2010, March 28.

OLIVEIRA, E. Brasil e Argentina vão fazer reatores nucleares. O Globo. 21 nov. 2007.

SCIENCE. Brazil's Nuclear Program: Carter's Nonproliferation Policy Backfires. Science, p. 657-659, 18 fev. 1977.

SILVA, O. L. P.; MARQUES, A. L. F. Enriquecimento de urânio no brasil: desenvolvimento da tecnologia por ultracentrifugação. Economia \& Energia, v. X, n. 54, 3 abr. 2006. 


\section{Bibliografia Primária}

2.1. Acordos internacionais, Declarações e Estudos Técnicos

AGNU. Comprehensive Nuclear-Test-Ban Treaty (Tratado De Interdição Completa De Testes Nucleares). Nova Iorque, 10 set. 1996

AIEA, Operational \& Long-Term Shutdown Reactors, Viena: 13 April 2013

AIEA. INFCIRC/153. The Structure and Content of Agreements between the Agency and States Required in Connection with the Treaty on the NonProliferation of Nuclear Weapons. Viena, Junho, 1972

AIEA. INFCIRC/435. Agreement of 13 December 1991 between the Republic of Argentina, the Federative Republic of Brazil, the Brazilian-Argentine Agency for Accounting and Control of Nuclear Materials and the International Atomic Agency for the Application of Safeguards. Viena, Março, 1994.

BRASIL, AlEMANHA. Acordo entre o Governo da República Federativa do Brasil e o Governo da República Federal da Alemanha sobre Cooperação no Campo dos Usos Pacíficos da Energia Nuclear. Brasília, 1975

BRASIL, ARGENTINA. Declaração Conjunta sobre Política Nuclear. Declaração de Ezeiza. Buenos Aires, 29 nov. 1988.

BRASIL, ARGENTINA. Declaração sobre Política Nuclear Brasileiro-Argentina. Declaração de Foz do Iguaçu. Foz do Iguaçu, 28 novembro 1985

BRASIL, ARGENTINA, ABACC, AIEA. Acordo entre a República Federativa do Brasil, a República Argentina, a Agência Brasileiro-Argentina e Contabilidade e Controle de Materiais Nucleares (ABACC) e a Agência Internacional de Energia Atômica (AIEA) para a Aplicação de Salvaguardas. Viena,13 dez. 1991

BRASIL, CHINA. Acordo entre o Governo da República Federativa do Brasil e o Governo da República Popular da China para Cooperação nos Usos Pacíficos da Energia Nuclear. Pequim, 11 outubro 1984. 
BRASIL, G 8, Argentina, Ucrânia, África do Sul, Filipinas. Joint Declaration Towards a World Free From Nuclear Weapons: The Need of a New Agenda. Brasília, 09 jun. 1998

BRASIL; ALEMANHA. Bekanntmachung des Abkommens zwichen der Regierung der Bundesrepublik Deutschland und der Regierung der Föderativen Republik Brasilien über Zusammenarbeit auf dem Gebiet der friedlichen Nutzung der Kernenergie. 9 fev. 1976.

THE BREAKTHROUGH INSTITUTE (TBI). An Ecomodernist Manifesto. Oakland: The Breakthrough Institute, 2015.

Tratado para la Proscripción de las Armas Nucleares en la América Latina y el Caribe (Tratado de Tlatelolco). Cidade do México, 12 dev. 1967. Disponível em: $<$ http://www.opanal.org/texto-del-tratado-de-tlatelolco/> Acessado em 16 Abr. 2016

BRASIL; ARGENTINA Acordo entre a República Federativa do Brasil e a República Argentina para o uso exclusivamente pacífico de energia nuclear (Tratado de Guadalajara). Guadalajara, México: 1991.

BRASIL, ARGENTINA. DECLARAÇÃO SOBRE POLÍTICA NUCLEAR COMUM BRASILEIRO - ARGENTINA (Declaração de Foz do Iguaçu). Foz do Iguaçu, 1990.

2.2. Discursos de altas autoridades brasileiras

CARdoso, F. H. Discurso de Posse do Excelentíssimo Senhor Presidente da República, Fernando Henrique Cardoso, no Congresso Nacional. Brasília, 1o de janeiro de 1995.

CARDOSO. Apresentação perante a Comissão de Relações Exteriores da Câmara dos Deputados. Brasília, 31 de março de 1993. In.: Política Externa em Tempos de Mudança: a gestão do Ministro Fernando Henrique Cardoso no Itamaraty. Brasília: FUNAG, 1994. 
COLLOR, F. Discurso pronunciado por Sua Excelência o Senhor Fernando Collor, Presidente da República Federativa do Brasil, por ocasião da abertura do debate geral da XLV Sessão da Assembleia Geral das Nações Unidas, Nova Iorque, EUA, no dia 24 de setembro de 1990.

COLlOR, F. Mensagem Ao Congresso Nacional Na Abertura Da La Sessão Legislativa Ordinária Da 49a Legislatura . Brasília, 1992

FRANCO, I. Discurso do Senhor Presidente da República, Itamar Franco, na Primeira Sessão de Trabalho, em Assuntos Políticos, durante a VIII Cúpula Presidencial do Grupo do Rio. Santiago do Chile, 15 de outubro de 1993.

PATRIOTA, A. A. Statement by H.E. Antonio de Aguiar Patriota Ambassador, Permanent Representative of Brazil to the United Nations. Review Conference of the Parties to the Treaty on the Non-Proliferation of Nuclear Weapons, New York, 28 April 2015

SARNEY, J. Discurso Abertura dos Debates da Assembleia Geral da ONU. “Afirmação da Soberania Brasileira.” Nova Iorque, 23 de setembro de 1985.

SARNEY, J. Discurso ao receber o Primeiro-Ministro Chinês. “Posições comuns em prol da paz, do desarmamento e de reformas profundas que façam mais justa a ordem econômica internacional.”. Brasília, 31 de outubro de 1985

SARNEY, J. Discurso de Inauguração da Ponte Tancredo Neves Fronteira BrasilArgentina. "O relacionamento Brasil-Argentina se singulariza por uma cooperação dinâmica, igualitária e mutuamente benéfica que se patenteia por meio de realizações concretas.” Fronteira Brasil-Argentina, 29 de novembro de 1985

SARNEY, J. Discurso do Dia do Diplomata. "O diplomata brasileiro representa uma nação sem inimigos. A paz torna nossa atividade diplomática um incessante abrir caminhos, uma incansável construção de relacionamentos." Brasília, 13 de maio de 1987. 
SARNEY, J. Discurso em Visita à Argentina. "Ambos os povos assumem neste momento, perante a História, um compromisso longamente amadurecido, definitivo: a integração.” Na Assembleia Legislativa Buenos Aires, 29 julho 1986.

\subsection{Discursos de presidentes americanos}

CARTER, J. Interview With the President Remarks and a Question and Answer Session With Senior Editors on Latin American Affairs., 22 set. 1978. Disponível em: <http://www.presidency.ucsb.edu/ws/index.php?pid=29844>. Acesso em: 2 nov. 2015

CARTER, J. The President's Trip to Latin America and Africa Remarks on Arrival at the White House., 3 abr. 1978. Disponível em: <http://www.presidency.ucsb.edu/ws/index.php?pid=30611>. Acesso em: 2 nov. 2015

JOHNSON, L. Statement by the President on the Treaty for the Prohibition of Nuclear Weapons in Latin America. February 14, 1968

NIXON, R. Message to the Senate Transmitting Additional Protocol II to the Treaty for the Prohibition of Nuclear Weapons in Latin America. August 13, 1970

2.4. Depoimentos orais, entrevistas e conferências

ALMEIDA, S. G. DE. Entrevista escrita concedida ao autor por Sílvio Gonçalves de Almeida, inspetor aposentado da ABACC e da AIEA, em 25 fev. 2016.

CARASALES, J. Institute for Science and International Security. (ISIS) (Ed.). In: The Evolution Of The Argentine-Brazilian Nuclear Raprochement. Washington: 16 maio 1996. Disponível em: <http://isis-online.org/596am1a>. Acesso em: 20 abr. 2016

CARVALHO, J. L. S. Entrevista ao autor concedida por José Luiz de Santana Carvalho, presidente da CNEN durante o governo Collor, em 18 fev. 2016. 
CERVO, A. L. Palestra realizada sobre a contribuição latino-americana aos estudos de Relações Internacionais, no Instituto de Relações Internacionais da Universidade de Brasília, em 26 de maio de 2015.

FUNCIONÁRIO CNEN 1. Entrevista concedida ao autor por um alto-funcionário da CNEN durante o governo Collor, em dezembro de 2015.

GOLDEMBERG, José. José Goldemberg (depoimento, 1976), Ministro da Ciência e Tecnologia durante o governo Collor. Rio de Janeiro, CPDOC, 2010. 163 p.

LAMPREIA, Luiz Felipe. Luiz Felipe Lampreia (depoimento,2008). Rio de Janeiro, CPDOC, 2010.

SCHENONI, Luís; ESCUDÉ, Carlos. Peripheral Realism Revisited - an interview with Luis Schenoni and Carlos Escudé. Entrevista realizada pelo autor em 23 de março de 2016, para fins de divulgação de artigo da RBPI.

SILVEIRA, A. F.; SPEKTOR, M. (Org.) Azeredo Da Silveira: Um Depoimento. Rio de Janeiro, RJ, Brasil: FGV, 2010.

\subsection{Documentação Alemã}

AA. Aufzeichnung des Ministerialdirektors Fischer. doc 413-491.09, Nach Herrn Staatssekretär. Betr.: erneute amerikanische Bemühungen, ein nukleares Exportembargo über die Länder der Dritten Welt zu verhängen, die nicht auf Kernwaffen verzicheten., 23 fev. 1984.

AA. Aufzeichnung des Ministerialdirektors Hermes. 413-491.09 BRA VS NfD., 14 fev. 1975. IN.: KIENINGER, M.; LINDEMANN, M.; TASCHLER, D. (EDS.). Akten zur Auswärtigen Politik der Bundesrepublik Deutschland 1975: 1. Januar bis 30. Juni. [s.1.] Oldenbourg Verlag, 2006.

AA. Aufzeichnung des Ministerialdirektors Lautenschlager. 413-491.23 BRA212/75 VS-vertraulich. Betr.: Gespräch zwichen dem brasilianischen Außenminister Genscher anlässlich eines Abendessens in kleinen Kreis in Hause von Herrn Minister 
Genscher am 5. März 1978; hier: Urenco-Lieferungen an Brasilien., 3 jun. 1978. IN.: TASCHLER, D.; GUPTA, A. D.; MAYER, M. (EDS). Akten zur Auswärtigen Politik der Bundesrepublik Deutschland 1978: 1. Januar bis 31. Dezember. München: Oldenbourg Verlag, 2008.

\section{AA. Aufzeichnung des Ministerialdirektors Ruhfus, Bundeskanzleramt. VS-} vertraulich., 17 jun. 1977. In.: Akten zur Auswärtigen Politik der Bundesrepublik Deutschland 1977: 1. Januar bis 30. Juni. [s.1.] Oldenbourg Verlag, 2008. P. 161

AA. Aufzeichnung des Ministerladirigenten Dittmann. Dg 41. Über Herrn StaatssekretärH Herrn Bundesminister. Beti.: Konsultationen über Fragen der friedlichen Nutzung der Kernenergie mi F, FG und Kanada., 22 mar. 1977. In.: GUPTA, A.; GEIGER, T.; PETER, M; HILFRICH, F.; LINDEMANN, M.; PAUTSCH, I.D. (EDS.). Akten zur Auswärtigen Politik der Bundesrepublik Deutschland 1977: 1. Januar bis 30. Juni. München: Oldenbourg Verlag, 2008.

AA. Aufzeichnung von Ungerer. Referat 431, Bd 129425, 29 set. 1983. In.: GEIGER, T.; MATTHIAS, P.; MECHTHILD, L. (orgs). Akten zur Auswärtigen Politik der Bundesrepublik Deutschland 1983: 1. Januar bis 30. Juni. München: Oldenbourg Verlag, 2014. Pp. 281-283.

AA. Botschafter Röding, Brasília, na das Auswärtige Amt. 114-100987/77 geheim. Fernschreiben Nr. 74, Citissime nachts. Aufgabe: 16. Feb. 1977, 16.15 Uhr. Ankunft: 17 Feb. 1977, 03.23 Uhr. Betr.: Deutsch-amerikanische Konsultationen über Kernenergie und Nichtverbreitung am 10./11. Februar 1977., 16 fev. 1977. In.: GUPTA, A.; GEIGER, T.; PETER, M; HILFRICH, F.; LINDEMANN, M.; PAUTSCH, I.D. (EDS.). Akten zur Auswärtigen Politik der Bundesrepublik Deutschland 1977: 1. Januar bis 30. Juni. München: Oldenbourg Verlag, 2008.

\section{AA. Deutsch-niederländisches Regierungsgespräch. 014-StS-041/77 VS- vertraulich. Teilnehmer von Deuscher Seite: Bundesminister Genscher, Bundesminister Matthöfer, Bundesminister Friedrichs, Staatssekretär Hermes. Von der niederländischer Siete: Außenminister van der Stoel, Staatssekretär Koijmans, Botschaftler van Lynden., 13 jan. 1977.}


AA. Ministerialdirektor Lautenschlager an Botschafter von Staden, Washington. 413-491.09-670/76 VS-vertraulich. Fernschreiben Nr 523. 25 mai 1976. Betr.: Gespräch Bundesminister - AM Kissinger am 23 Mai 1976 in Bonn. Hier: Fragen der deutschen nuklearen Exportpolitik. Bezug: Telefongespräch Botschafter - D4 vom 23.5.1976

DEUTSCHER BUNDESTAG. Bundestagsdrucksache Nr. 16/7569. Antwort der Bundesregierung Zur Zukunft der nuklearen Abrüstung, Nichtverbreitung und Rüstungskontrolle, 12 dez. 2007.

DEUTSCHER BUNDESTAG. Drucksache 12/6253. Antwort der Bundesregierung - Drucksache 12/6056 - Deutsch-brasilianisches Nuklearabkommen. 12 Wahlperiode., 31 nov. 1993.

DEUTSCHER BUNDESTAG. Drucksache 18/1914. Antwort der Bundesregierung auf die Kleine Anfrage der Abgeordneten Sylvia Kotting-Uhl, Jürgen Trittin, Annalena Baerbock, weiterer Abgeordneter und der Fraktion BÜNDNIS 90/ DIE GRÜNEN - Drucksache 18/1700 - Bilaterale Atomabkommen mit Indien und Brasilien. 18. Wahlperiode, 26 jun. 2014.

DEUTSCHER BUNDESTAG. Drucksache 18/968 Antwort der Bundesregierung auf die Kleine Anfrage der Abgeordneten Sylvia Kotting-Uhl, Jürgen Trittin, Omid Nouripour, weiterer Abgeordneter und der Fraktion BÜNDNIS 90/DIE GRÜNEN - Drucksache 18/691 -. Zum deutsch-brasilianischen Atomabkommen und anderen Atomabkommen und zur staatlichen Förderung von Atomexporten. 18. Wahlperiode, 1 abr. 2014.

\subsection{Documentação Americana}

CIA. Brazil's Changing Nuclear Goals: Motives and Constraints: Special National Intelligence Estimate. Secret. Approved release date: 09/19/2011., 21 out. 1983.

CIA. National Intelligence Daily. Top Secret. Approved for release in 06/21/2010., 13 jan. 1982. 
CIA. President Sarney and Brazil's Nuclear Policy. Secret. Approved for Reselease 24/01/2011, $\quad 8$ Sept. 1986 . $\quad$ Disponível em: $<$ https://digitalarchive.wilsoncenter.org/document/116900>, acessado em 25/05/2016.

CIA. Scientific and Technical Intelligence Report: Proliferation of Missile Delivery Systems for Nuclear Weapons. Secret. Approved for release on 09/16/2009., 30 nov. 1967.

DEPARTMENT OF STATE. "US Embassy Paris cable 31540 to State Department, 'Elysée Views on Reprocessing Issues'," , History and Public Policy Program Digital Archive, Mandatory Declassification Review request. Obtained and contributed by William Burr and included in NPIHP Research Update \#3. <http://digitalarchive.wilsoncenter.org/document/112845, 23 set. 1978.>, acessado em 25/05/2016.

DEPARTMENT OF STATE. 116. Memorandum From the Senior Department of Defense Attaché in France (Walters) to the dr. Kissinger, Paris, undated.1, [s.d.]. Source: National Archives, Nixon Presidential Materials, NSC Files, Kissinger Office Files, Box 1, HAK Administrative and Staff Files, Transition, November 1968-January 1969, Brazil. Apesar de o documento não está datado, memorandos similares de Walters aconselhando sobre Europa Oriental e França sugerem que o documento data de 31 de dezembro de 1968.

DEPARTMENT OF STATE. 125. Brazil Program Analysis, Washington, November 1, 1969, 1 nov. 1969. National Archives, Nixon Presidential Materials, NSC Files, NSC Institutional Files (H-Files), Box H-49, Senior Review Group, Brazil Program Analysis, 12-1-70. Secret.

DEPARTMENT OF STATE. 141. Memorandum for the President's File, Washington, December 7, 1971, 11:30 a.m. From Henry Kissinger. Subject: Meeting with President Emílio Garrastazú Médici of Brazil on Tuesday, December 7, 1971, 11:30 a.m. in the President's Office, The White House.Source: National Archives, Nixon Presidential Materials, NSC Files, Box 1025, Presidential/HAK Memcons, Memcons-The President and President Médici, Dec. 7-9, 1971. Top Secret; Eyes Only. The conversation took place in the President's office., , 7 dez. 1971. 
DEPARTMENT OF STATE. Memorandum for the president, from Henry Kissinger. Subject: Brasil - Economic and Military Assistance., 18 mar. 1969. National Archives, Nixon Presidential Materials, NSC Files, Box 771, Country Files, Latin America, Brazil through August 1970. Confidential. Sent for action.

DEPARTMENT OF STATE. Telegram 0769 From the Embassy in Brazil to the Department of State. Suject: Brazilian aid to Uruguay and Bolivia., 7 mar. 1972. Source: National Archives, Nixon Presidential Materials, NSC Files, Box 772, Country Files, Latin America, Brazil, Vol. 2, August 1, 1971-December 1972. Secret; Priority; Exdis. Repeated to Buenos Aires, La Paz, and Montevideo.

DEPARTMENT OF STATE. US Embassy Cable, Brazilian Public Reaction to US Nuclear Policies., 19 nov. 1976.

ESTADOS UNIDOS. Federal Register / Vol. 61/ Issue 131 / Rules and Regulations, 8 jul. 1996.

ESTADOS UNIDOS. Federal Register / Vol. 61/ Issue 170 / Notices, 30 ago. 1996.

ESTADOS UNIDOS. Federal Register / Vol. 65, No. 198 / Notices, 12 out. 2000.

ESTADOS UNIDOS. Federal Register / Volume 60/ Issue 160 / Rules and Regulations, 18 ago. 1995.

ESTADOS UNIDOS. Federal Register / Volume 62/ Issue 203 / Presidential Documents, 21 out. 1997.

ESTADOS UNIDOS. Federal Register / Volume 62/ Issue 65 / Notices, 4 abr. 1997.

ESTADOS UNIDOS. Federal Register/ Volume 59/ Issue 166, 29 ago. 1994.

\subsection{Documentação Brasileira}

BATISTA, P. N. 621.039.9 (81)/B333p - Pronunciamento do Embaixador Paulo Nogueira Batista Presidente da Nuclebrás - Comissão Parlamentar de Inquérito 
(CPI) do Acordo Nuclear no Senado Federal. Arquivo Paulo Nogueira Batista, Brasília, 11 nov. 1980.

BATISTA, P. N. Notas tomadas por Paulo Nogueira Batista em reunião com o ministro Ueki, 11 jun. 1975. Arquivo: Paulo Nogueira Batista Classificação: PNB pn n 11 jun. 1975. Data: 11/06/1975 a 05/08/1982. Qtd.de documentos: 81 ( 379 fl. )

BATISTA, P. N. Notas tomadas por Paulo Nogueira Batista em reunião com militares, Sem data. Arquivo: Paulo Nogueira Batista Classificação: PNB pn n 05 ago. 1982. Data: 11/06/1975 a 05/08/1982. Qtd.de documentos: 81 ( 379 fl. )

BATISTA, P. N. Notas tomadas por Paulo Nogueira Batista em reunião com militares, 25 set. 1977. Arquivo: Paulo Nogueira Batista Classificação: PNB pn n 11 jun. 1975. Data: 11/06/1975 a 05/08/1982. Qtd.de documentos: 81 ( 379 fl. )

BRASIL. Cooperação nuclear Brasil-República Federal da Alemanha - constituição de empresas subsidiárias na Nuclebrás. Arquivo Paulo Nogueira Batista. CPDOC-FGV. Sem Data

BRASIL. I Plano Nacional de Desenvolvimento (PND): 1972/74. dez. 1971. Diponível em: <http://bibspi.planejamento.gov.br/handle/iditem/322>. Acesso em 01 nov. 2015

BRASIL. II Plano Nacional de Desenvolvimento, 1974. Disponível em: <http://www.planalto.gov.br/ccivil_03/leis/1970-1979/anexo/ANL6151-74.PDF>. Acesso em: 31 out. 2015

BRASIL. III Plano Nacional de Desenvolvimento : 1980/85, set. 1980. Disponível em: <http://bibspi.planejamento.gov.br/handle/iditem/493?show=full>. Acesso em: 31 out. 2015

BRASIL. Livreto Programa Nuclear Brasileiro: Governo Presta Contas, secretaria de comunicação social da presidência da república,, 1981. Arquivo pessoal de Paulo Nogueira Batista, CPDOC, Rio de Janeiro.

CARVAlHO, H. G. DE. O Programa Nuclear Brasileiro. Brasília: 1980. Arquivo pessoal de Paulo Nogueira Batista, CPDOC, Rio de Janeiro. 
CARVALHO, J. F. DE. "Energia nuclear no Brasil: Novos Rumos? Participação nacional - criação e transferência de tecnologia". Palestra realizada na Associação Brasileira de Energia Nuclear. Arquivo CPDOC, FGV - Política Energética 08.10.1984 a 18.12.1984 - 1984.03.00 pasta III. 13 nov. 1984.

CONGRESSO NACIONAL (CN). Relatório no 13, DF 1990. Comissão Mista de Inquérito destinada a apurar o programa autônomo de energia nuclear, também conhecido como "programa paralelo". Relatório Final. Relator: Senador Severo Gomes, 1990.

CSN.. Memorando, Informação para o Presidente da República, Brasil, No. 011/85, do Conselho de Segurança Nacional, Estrutura do Programa Nuclear Paralelo. De Danilo Venturini (Ministro de Estado - Secretário-Geral do CSN). CPDOC, Fundação Getúlio Vargas (FGV), 21 fev. 1985.

FURNAS. Furnas-Centrais Elétricas S.A. Financing of the Angra dos Reis II and III Nuclear Power Plants. Arquivo Paulo Nogueira Batista. CPDOC-FGV. jun. 1976;

LAMPREIA. Memoradum sem destinário. 01 aug. 1998. In.: Arquivo: Luiz Felipe Lampreia Classificação: LFL mre1 1998.06.00 Data: 00.06.1998 a 01.08.1998. Qtd.de documentos: 2 ( 5 fl. ). Arquivo CPDOC-FGV, Rio de Janeiro.

MME, NUCLEBRÁS. Cooperação nuclear Brasil-República Federal da Alemanha - constituição de empresas subsidiárias na Nuclebrás, 1975. Arquivo pessoal de Paulo Nogueira Batista, CPDOC, Rio de Janeiro.

MME. "Memorandum, Shigeaki Ueki, Brazilian Minister of Energy on Nuclear Energy Cooperation with Iraq," History and Public Policy Program Digital Archive, CPDOC Archives, PNB pn a 1978.07.13 pp.22-27., 17 jan. 1979.

MRE, MME. Informação para o senhor Presidente da República. Índice: Cooperação Nucler. Brasil-RFA. 0246. Secreto. 15 out. 1974

MRE. "Brazilian Embassy Cable, Brazilian Ambassador to Bonn Reports on Soviet Pressure on West Germany," , History and Public Policy Program Digital 
Archive, Centro de Pesquisa e Documentação de História Contemporânea do Brasil (CPDOC), Fundação Getúlio Vargas (FGV), Azeredo da Silveira Archive, AAS mre pn 1974.08.15 pp. 589-591. Obtained and translated by Fundação Getúlio Vargas., 21 mar. 1977.

MRE. "Memorandum, Foreign Minister Azeredo da Silveira, Information for the President of Brazil, 'Nuclear Issues. Meeting at 13/02/78. Alvorada Palace.,", History and Public Policy Program Digital Archive, CPDOC Archives, AAS mre d 1974.03.26 pp.12361-12366, 23 fev. 1978.

MRE. AAS mre d 1974.03.26. Assunto: politica externa dos EUA. Telegrama de Araújo Castro para o Ministro Azeredo da Silveira. Secreto., 26 mar. 1974. Arquivo: Antônio Azeredo da Silveira, CPDOC-FGV, Rio de Janeiro.

MRE. ASS 0274. Informação para o Senhor Presidente da República. Índice: Petróleo e Energia Nuclear. Visita a Paris do Ministro Paulo Nogueira Batista, chefe do DEC. Secreto., 18 nov. 1974.

MRE. Cable from Brazilian Embassy in Bonn to Brasilia, 'Nuclear energy. South Africa: Uranium Enrichment', 29 Out. 1979, History and Public Policy Program Digital Archive, CPDOC Archives, Ramiro Saraiva Guerreiro collection. Obtained and $\begin{array}{lllll}\text { translated } & \text { by } & \text { Fundação } & \text { Getúlio }\end{array}$ $<$ http://digitalarchive.wilsoncenter.org/document/116660>, acessado em 24 de abril de 2016

MRE. Cable from Brazilian Embassy in Bonn to Brasilia, 'Nuclear Energy. Hamburg Congress: South African Program', 16 Maio 1979, History and Public Policy Program Digital Archive, CPDOC Archives, Ramiro Saraiva Guerreiro collection. Obtained and translated by Fundação Getúlio Vargas. $<$ http://digitalarchive.wilsoncenter.org/document/116658>, acessado em 24 de abril de 2016

MRE. Cable on Ambassador Rubens Ricupero's Meetings with President Alfonsín and Ambassador Jorge Sabato about Nuclear Cooperation, 04 set. 1987, History and Public Policy Program Digital Archive, AHMRE. Obtained and translated by 
Fundação

Getúlio

Vargas.

Disponível

em:

<http://digitalarchive.wilsoncenter.org/document/117523>. Acessado em 13/05/2016

MRE. Cables between the Brazilian Embassy in Washington and the Brazilian Foreign Ministry on the Transfer of Nuclear Material, 1975, History and Public Policy Program Digital Archive, CPDOC-FGV, Arquivo de Azeredo da Silveira, AAS mre d 1974.03.26 p.5116-5127, 26 mar. 1974.

MRE. Explanatory Memorandum from the National Security Council to the President of Brazil, 08 set 1974, History and Public Policy Program Digital Archive, CPDOC Archives, Antonio Azeredo da Silveira, AAS 1974.09.11. Obtained and translated by $\quad$ Fundação Getúlio Vargas. $<$ https://digitalarchive.wilsoncenter.org/document/116853>, acessado em 25/05/2016.

MRE. Índice: relações Brasil-Argentina. Visita de trabalho do Senhor Ministro de Estado a Buenos Aires. 20 e 21 de Maio de 1985. 040. secreto. Arquivo CPDOCFGV, Rio de Janeiro. Rba.mpc.c. 1985.01.10 19 documentos ; 168 páginas; pasta 1

MRE. Informação para ao senhor Presidente da República, do Ministro Azeredo da Silveira. A energia nuclear na Argentina. Confidencial. MRE/d 0041, 4 abr. 1974.

MRE. Informação para o ministro de Estado, de Paulo Nogueira Batista sobre enriquecimento de uranio. Secreto. Arquivo pessoal de Paulo Nogueira Batista, CPODOC-FGV, Rio de Janeiro., abril 1971.

MRE. Informação para o Semhor Presidente da República. Índice: energia nucler. 0095. De: Ministro Antônio F. Azeredo da Silveira, 14 maio 1974, CPDOC-FGV, Arquivo de Azeredo da Silveira,

MRE. Informação para o senhor Presidente da República. Índice: Energia Nuclear. Artigos da revista “estratégia”. Confidencial., 9 maio 1974.

MRE. Informação para o Senhor Presidente da República. Índice: os entendimentos argentino-indianos no campo nuclear. Possibilidades de detonação de uma bomba pela Argentina. Secreto. 0116, 6 mar. 1974. 
MRE. Informação. Tratado de Tlatelolco para a Proscrição de Armas Nucleares na América Latina. Secreto. Sem data. Arquivo: Paulo Nogueira Batista (PNB pna 1979.03.12 Data: 12/03/1979 a 22/06/1982 Qtd.de documentos: 11 ( 30 fl. )). Arquivo CPDOC-FGV, Rio de Janeiro.

MRE. Informações ao senhor chefe do DEC. Secreto. Energia Nuclear. Relações Brasil-Argenitna. 30 de abril de 1985. In: Rba.mpc.c. 1985.01.10 19 documetnos 168 páginas. pasta 1. Arquivo CPDOC-FGV, Rio de Janeiro.

MRE. Informações ao senhor chefe do DEC. Secreto. Energia Nuclear. Relações Brasil-Argentina. 30 Abril 1985. In.: Arquivo Rba.mpc.c. 1985.01.10 19 documentos, 168 páginas, pasta 1 . Arquivo CPDOC-FGV, Rio de Janeiro.

MRE. Information from Brazilian Minister of Foreign Affairs Saraiva Guerreiro to President Figueiredo, 'Nuclear Energy. South Africa', 05 Novembro 1979, Arquivo CPCDOC-FGV, Rio de Janeiro. Arquivos de Ramiro Saraiva Guerreiro. Disponível no acervo do Wilson Center $<$ http://digitalarchive.wilsoncenter.org/document/116662>, acessado em 25/05/2016.

MRE. Letter, Argentinian President Bignone to Brazilian President Figueiredo. 18 Nov. 1983, History and Public Policy Program Digital Archive, Folha de São Paulo, page 4, November 19 1983. Obtained and translated by Fundação Getúlio Vargas. Disponível em: <http://digitalarchive.wilsoncenter.org/document/116864>, acessado em $13 / 05 / 2016$.

MRE. Memorandum from the Argentine General Directorate for Nuclear Affairs and Disarmament, 'Cooperation with Brazil in the Feld of Peaceful Uses of Nuclear Energy'. 13 Maio 1985, History and Public Policy Program Digital Archive, CPDOC Archives, Rubens Barbosa collection. Obtained and translated by Fundação Getúlio Vargas. Disponível em: $<$ https://digitalarchive.wilsoncenter.org/document/117518>, acessado em 13/05/2016

MRE. Memorandum para o Sr ministro de Estado em 10 de janeiro de 1985. Secreto. G/08. Assunto: Brasil-Argentina. Energia Nuclar. De Emb. Roberto Abdenur. Arquivo CPDOC-FGV, Rio de Janeiro. Rba.mpc.c. 1985.01.10 19 documentos; 168 páginas; pasta 1 
MRE. Memorandum para o Sr ministro de Estado em 10 de janeiro de 1985. Secreto. G/08. Assunto: Brasil-Argentina. Energia Nuclar. De Emb. Roberto Abdenur. 10 jan. 1985. In.: Arquivo Rba.mpc.c. 1985.01 .1019 documentos, 168 páginas, pasta 1. Arquivo CPDOC-FGV, Rio de Janeiro.

MRE. Memorandum, Minister Saraiva Guerreiro, Information for the President of Brazil, 'Brazil-PRC. Nuclear Energy'. April 04, 1984, History and Public Policy Program Digital Archive. Obtained and translated by Fundação Getúlio Vargas. <http://digitalarchive.wilsoncenter.org/document/116872>, acessado em 29 fev. 2016

MRE. Memorandum, Minister Saraiva Guerreiro, Information for the President of Brazil, 'Brazil-PRC. Nuclear Energy'. 04 abril 1984, Arquivo Wilson Center, traduzido pela FGV. Disponível em: <http://digitalarchive.wilsoncenter.org/document/116872>, acessado em 29 fev. 2016

MRE. Memorandum, Shigeaki Ueki, Brazilian Minister of Energy on Nuclear Energy Cooperation with Iraq. 17 Janeiro 1979, Arquivo CPDOC-FGV, Rio de Janeiro. Pasta: PNB pn a 1978.07.13 pp.22-27. Disponível no arquivo do Wilson Center: 〈http://digitalarchive.wilsoncenter.org/document/116867>, acessado em 24 de abril de 2016

MRE. N685.6(F36) (B46) • DEOc/DAI/212-A/N685.0(F36). Ajuste sobre a Realização de Visita do Navio Nuclear “Otto Hahn” ao Brasil., 27 jul. 1972. Disponível em: <http://dai-mre.serpro.gov.br/atosinternacionais/bilaterais/1972/b_70/>. Acesso em: 2 nov. 2015

MRE. Relato das conversações com o Chanceler da Argentina, Doutor Dante Caputo, em duas reuniões de trabalho no dia 20 de Maio de 1985. In.: Rba.mpc.c. 1985.01.10. Pasta II. CPDOC-FGV, Rio de Janeiro.

MRE. Relatório sobre a Argentina. Visita do Senhor Ministro de Estado à Argentina. 20 a 21 de maio de 1985. DAM-1, 06 maio 1985. In.: Rba.mpc.c. 1985.01.10, pasta 1. Arquivo CPDOC-FGV, Rio de Janeiro.

MRE. Report, Brazil, 'Official Mission to Washington, DC, While Representing Brazil at the Treaty Signing Ceremonies on the New Agreements Over the Panama 
Canal', 07 Set. 1977. History and Public Policy Program Digital Archive, CPDOC Archives, Antonio Azeredo da Silveira, AAS 1974.04/23. Obtained and translated by Fundação Getúlio Vargas. Disponível <http://digitalarchive.wilsoncenter.org/document/116859>, acessado em 13/05/2016

NUCLEBRÁS. Antecedentes de tentativa para estabelecimento de uma cooperação com o México no campo nuclear. 12 março 1979. Arquivo: Paulo Nogueira Batista (PNB pna 1979.03.12 Data: 12/03/1979 a 22/06/1982 Qtd.de documentos: 11 ( 30 fl. )). Arquivo CPDOC-FGV, Rio de Janeiro.

NUCLEBRÁS. Informação para Senhor Ministro de Estado Secretário-Geral do Conselho de Segurança Nacional. Concorrência Internacional no México. 22 jun. 1982. Arquivo: Paulo Nogueira Batista (PNB pna 1979.03.12 Data: 12/03/1979 a 22/06/1982 Qtd.de documentos: 11 ( 30 fl. )). Arquivo CPDOC-FGV, Rio de Janeiro.

NUCLEBRÁS. On access to and participation in the Brazilian Nozzle enrichment programme. Jan. 1982. Arquivo: Paulo Nogueira Batista (PNB pna 1979.03.12 Data: 12/03/1979 a 22/06/1982 Qtd.de documentos: 11 ( 30 fl. )). Arquivo CPDOC-FGV, Rio de Janeiro.

NUCLEBRÁS. Telegrama do Presidente da Nuclebrás, Paulo Nogueira Batista, ao General Danilo Venturini, Ministro de Estado Secretário-Geral do Conselho de Segurança Nacional. Aditamento aos telexes PR-288 e 291/81. Sem data. Reservado. Arquivo: Paulo Nogueira Batista (PNB pna 1979.03.12 Data: 12/03/1979 a 22/06/1982 Qtd.de documentos: 11 ( 30 fl. )). Arquivo CPDOC-FGV, Rio de Janeiro.

SF. A Questão Nuclear: Relatório da Comissão Parlamentar de Inquérito do Senado Federal, Resolução No 69-78. Relator: Senador Milton Cabral. Senado Federal, , 17 ago. 1982.

SILVEIRA, A. Memorandum, Foreign Minister Azeredo da Silveira, Information for the President of Brazil, 'Uranium Enrichment'," April 02, 1974, History and Public Policy Program Digital Archive, CPDOC Archives, PNB ad 1973.10.05 pp. 100108. Obtained and translated by Fundação Getúlio Vargas. $<$ http://digitalarchive.wilsoncenter.org/document/116875>, acessado em 05/05/2016 
VON SIEMENS, P. Documento 478592. Cooperação nuclear Brasil-República Federal da Alemanha - constituição de empresas subsidiárias na Nuclebrás. Discurso do presidente do Conselho de Administração da Siemens, sr. Peter von Siemens, 1976.

\subsection{Documentação diversa}

ABACC. Relatório Anual. Rio de Janeiro, 1993.

ALVIM, C. F. Statement by the Deputy Secretary of the Brazilian-Argentine Agency for Accounting and Control of Nuclear Materials (ABACC), Dr. Carlos Feu Alvim, at the 2000 NPT Review Conference. Nova Iorque, 14 Abril - 19 Maio, 2000. Disponível em: <http://www.nuclearfiles.org/menu/key-issues/nuclearweapons/issues/proliferation/argentina/2000-04-27_NPT-RevCon_Alvim_print.html>. Acessado em 12 mai. 2016.

CNEA. Note from the Director of Argentinian National Atomic Energy Commission (CNEA) on a Possible Agreement with Brazil, February 16, 1972, History and Public Policy Program Digital Archive, AMRECIC, Caja Brasil AH0124. Obtained and translated by Fundação Getúlio Vargas. <http://digitalarchive.wilsoncenter.org/document/116851>, acessado em 25/05/2016.

Emb. Argentina. Telegram, Argentine Embassy in Brasilia, Brazil and China Deny Charges of Nuclear Proliferation. 24 out. 1985. History and Public Policy Program Digital Archive, Telegrama ordinario, cable 1674, Aquivo Argentino. Obtained and translated by Fundação Getúlio Vargas. $<$ http://digitalarchive.wilsoncenter.org/document/116878>, acessado em 25/05/2016.

OPANAL. "Telegrama de Héctor Gros Espiell, secretário geral da OPANAL, a Azeredo da Silveira.", History and Public Policy Program Digital Archive, Centro de Pesquisa e Documentação de História Contemporânea do Brasil (CPDOC), Fundação Getúlio Vargas (FGV), Azeredo da Silveira Archive, AAS mre pn 1974.08.15 pp. 589591. Obtained and translated by Fundação Getúlio Vargas., 29 mar. 1977. 


\section{Anexos}

Anexo 1 - Usinas Nucleares no Mundo, 1978.

\begin{tabular}{|c|c|c|c|c|c|c|}
\hline \multirow{2}{*}{ Países } & \multicolumn{2}{|c|}{ Em Serviço } & \multicolumn{2}{|c|}{ Em Construção } & \multicolumn{2}{|c|}{ Encomendado } \\
\hline & Megawatts & Número & Megawatts & Número & Megawatts & Número \\
\hline Alemanha & 8,4 & 15 & 12,6 & 12 & 4,6 & 4 \\
\hline Argentina & 0,3 & 1 & 0,6 & 1 & 0,6 & 1 \\
\hline Brasil & 0 & 0 & 1,9 & 2 & 1,3 & 1 \\
\hline Canadá & 5,5 & 11 & 4,1 & 7 & 6,1 & 8 \\
\hline Espanha & 1,1 & 3 & 8,2 & 9 & 7,8 & 8 \\
\hline $\begin{array}{l}\text { Estados } \\
\text { Unidos }\end{array}$ & 52,4 & 74 & 90 & 83 & 53,8 & 47 \\
\hline França & 6,5 & 14 & 25,9 & 27 & 2,2 & 2 \\
\hline Inglaterra & 8,2 & 33 & 3,7 & 6 & 2,5 & 4 \\
\hline Japão & 13,4 & 22 & 5,8 & 7 & 7,2 & 9 \\
\hline Outros países & 11,3 & 26 & 31,1 & 39 & 12,1 & 12 \\
\hline $\begin{array}{l}\text { Países } \\
\text { Comunistas }\end{array}$ & 10,9 & 36 & 28,8 & 41 & 12,0 & 17 \\
\hline Total & 118 & 235 & 212,7 & 236 & 110,2 & 113 \\
\hline
\end{tabular}

Fonte: BRASIL. Livreto Programa Nuclear Brasileiro: Governo Presta Contas, secretaria de comunicação social da presidência da república, 1981. Arquivo pessoal de Paulo Nogueira Batista, CPDOC, Rio de Janeiro.

Anexo 2 - Produção Mundial de Energia por Matriz, Nuclear (Terawatts/Hora)

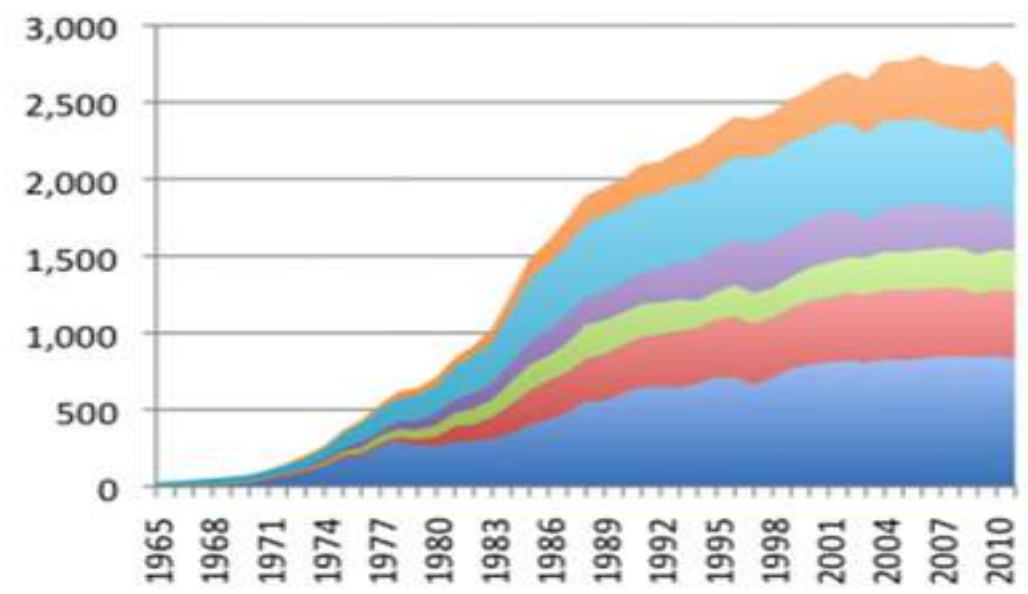

Legenda: Estados Unidos; França; Antiga União Soviética; Japão;

Europa (menos França); Restante.

Fonte: BP, 2012 Statistic Review of World Energy. 
Anexo 3 - Produção de Energia Nuclear e Acidentes Nucleares no longo prazo (em MW)

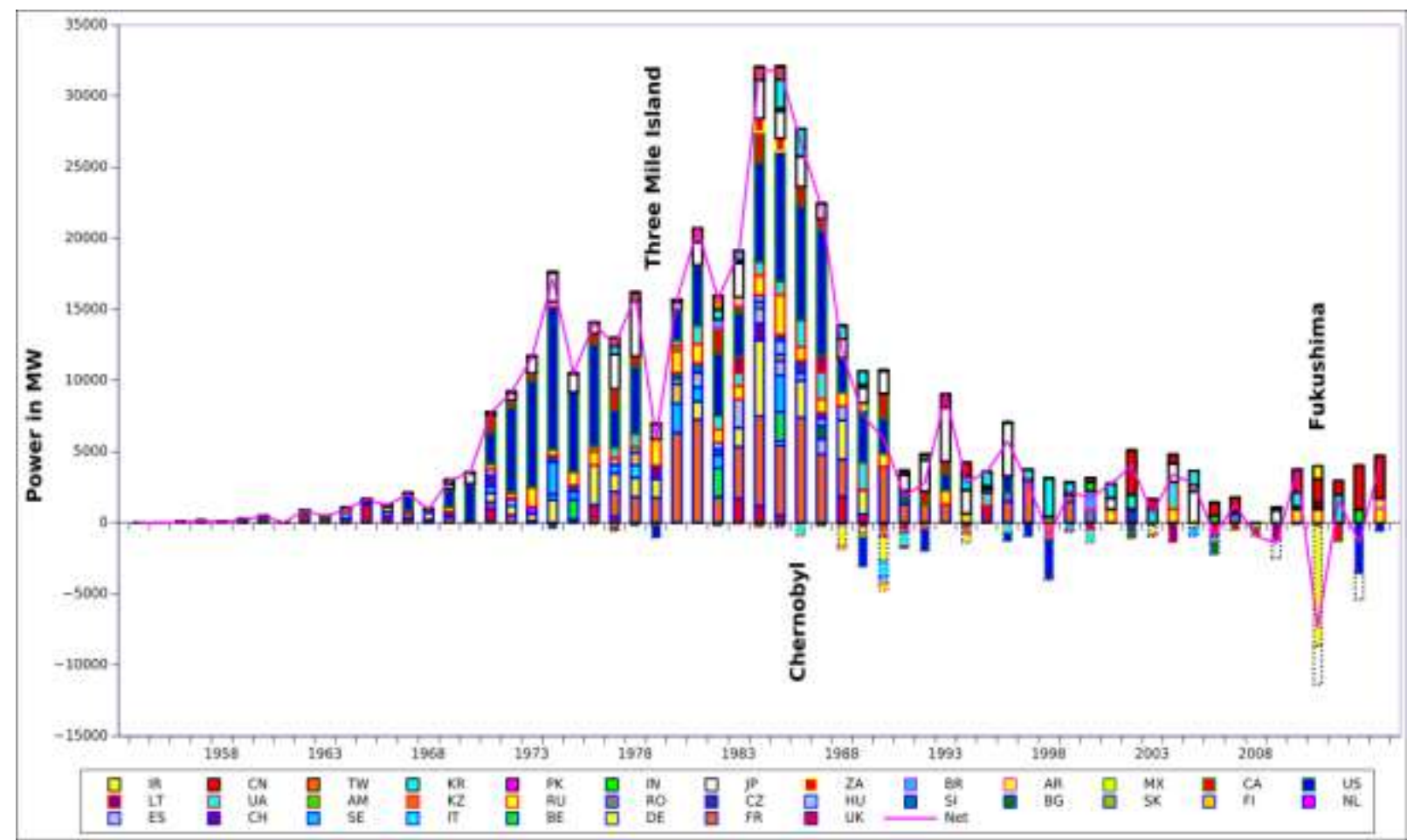

Fonte: AIEA, Operational \& Long-Term Shutdown Reactors, Viena: 13 Abril 2013. 
Anexo 4 - Produção Elétrica de Energia Nuclear

\begin{tabular}{|c|c|c|c|c|c|c|}
\hline \multicolumn{4}{|c|}{ Previsões Iniciais (1975) } & \multicolumn{3}{|c|}{ Resultados Verificados } \\
\hline \multirow[b]{2}{*}{ Ano } & \multirow[b]{2}{*}{ Estágio } & \multicolumn{2}{|c|}{ Centrais Nucleares } & \multicolumn{3}{|c|}{ Produção de Emergia Primária por Urânio } \\
\hline & & MWe/Ano & $\begin{array}{l}\text { Acumulado } \\
\text { (MW) }\end{array}$ & MW & $\begin{array}{l}\text { Acumulado } \\
\text { (MW) }\end{array}$ & $\begin{array}{c}\text { Participação Nacional } \\
\qquad(\%)\end{array}$ \\
\hline 1979 & & 627 & 627 & 0 & 0 & 0 \\
\hline 1980 & & - & 627 & 0 & 0 & 0 \\
\hline 1981 & & - & 627 & 0 & 0 & 0 \\
\hline 1982 & & - & 627 & 16 & 16 & 3,8 \\
\hline 1983 & & 1.300 & 1.927 & 0 & 0 & 2,7 \\
\hline 1984 & Dromoto & 1.300 & 3.227 & 857 & 873 & 1,4 \\
\hline 1985 & & - & 3.227 & 916 & 1.789 & 0,9 \\
\hline 1986 & & 1.300 & 4.527 & 37 & 1.826 & 0,3 \\
\hline 1987 & & 1.300 & 5.827 & 291 & 2.117 & 1,0 \\
\hline 1988 & & 1.300 & 7.127 & 167 & 2.284 & 0,2 \\
\hline 1989 & & $2 \times 1.300$ & 9.727 & 473 & 2.757 & 0,3 \\
\hline 1990 & & 1.300 & 11.027 & 598 & 3.355 & 0 \\
\hline 1991 & & $2 \times 1.300$ & 13.627 & 422 & 3.777 & 0 \\
\hline 1992 & & $2 \times 1.300$ & 16.227 & 347 & 4.124 & 0 \\
\hline 1993 & & $3 \times 1.300$ & 20.127 & 145 & 4.269 & 0 \\
\hline 1994 & & $3 \times 1.300$ & 24.027 & 43 & 4.312 & 0 \\
\hline 1995 & & $5 \times 1.300$ & 30.527 & 911 & 5.223 & 0 \\
\hline 1996 & & $6 \times 1.300$ & 38.327 & 783 & 6.006 & 0 \\
\hline 1997 & & $6 \times 1.300$ & 46.127 & 1.164 & 7.170 & 0 \\
\hline 1998 & & $8 \times 1.300$ & 56.527 & 1.522 & 8.692 & 0 \\
\hline 1999 & & $9 \times 1.300$ & 68.227 & 1.391 & 10.083 & 0 \\
\hline 2000 & & $10 \times 1.300$ & 81.227 & 1.806 & 11.889 & 0,1 \\
\hline
\end{tabular}

Fontes: Livreto “O Programa Nuclear Brasileiro”, Hervásio Guimarães de Carvalho (presidente da CNEN), Brasília, 1980; MME, Séries Históricas Completas, Balanço Energético Nacional; SF, 1980. Elaboração Própria. 
Anexo 5 - Organograma da ABACC entre 1995 e 1998.

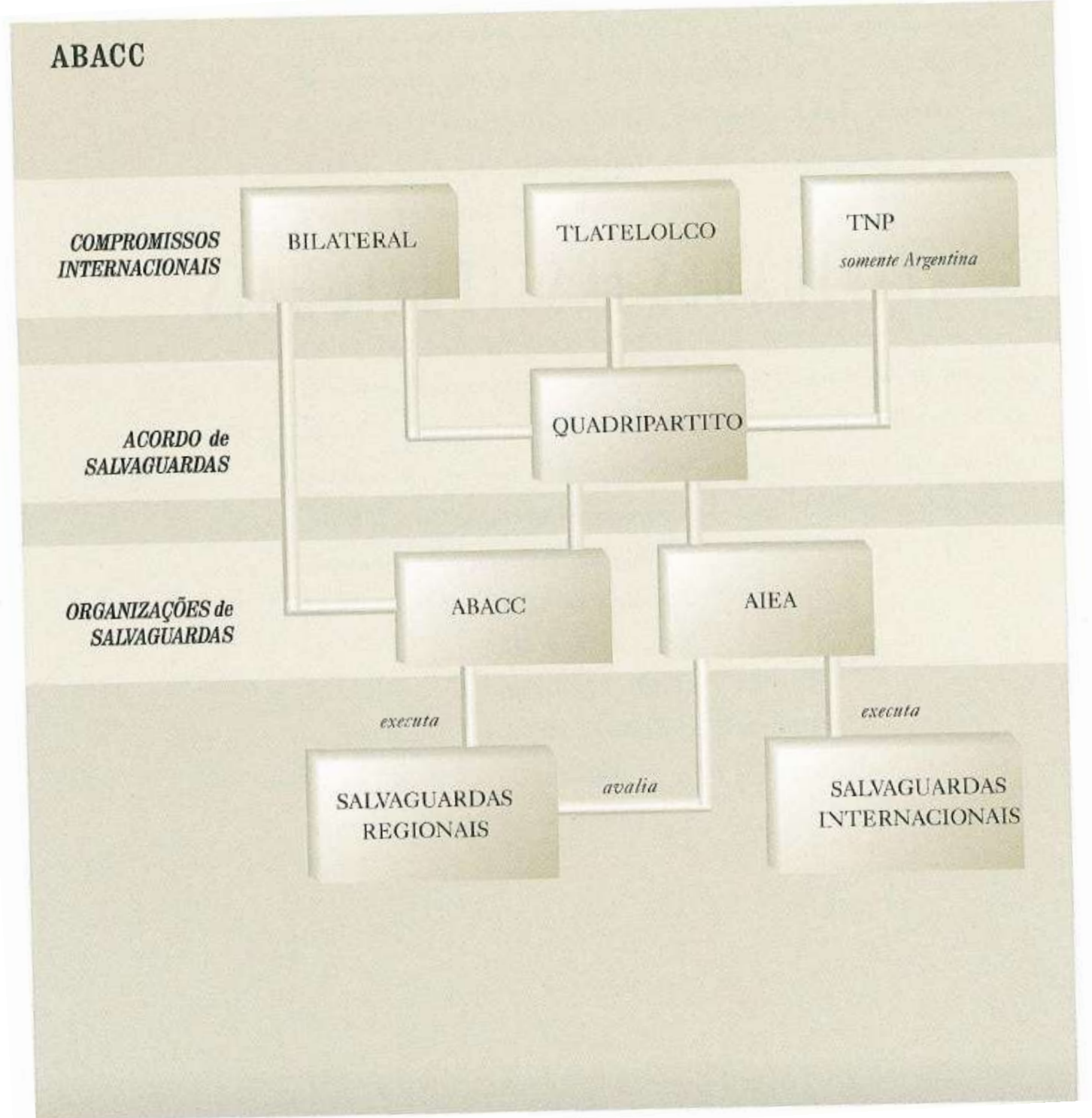

Fonte:Relatório Anual da ABACC, 1995, p. 8. Disponível em: < http://www.abacc.org.br/wpcontent/uploads/2012/10/Relatorio-anual-1995.pdf>, acessado em 14/05/2016. 
Anexo 6 - Entrevista com Silvio de Almeida, concedida em 25 de fevereiro de 2016.

Nota biográfica: Silvio de Almeida foi inspetor de salvaguardas da CNEN, da ABACC e da AIEA. Atuou naquela organização em seus momentos iniciais e foi participe da formulação da ABACC e do Acordo Quadripartite.

Metodologia: a entrevista foi realizada por escrito, via e-mail, e as perguntas, previamente formuladas, foram dividas em seções temáticas.

\section{Íntegra da entrevista:}

\section{1. formação e os anos iniciais da $A B A C C$}

1.1. Segundo me foi informado, o senhor trabalhou na ABACC nos anos iniciais da agência e, posteriormente, no AIEA, na área de salvaguardas. Como você descreveria os anos iniciais da $\mathrm{ABACC}$, no que concerne à formação de corpo técnico especializado no campo nuclear?

Resposta:

Na verdade, iniciei minhas atividades em salvaguardas nucleares na Divisão de Salvaguardas da CNEN em 1980, vindo do Centro de Engenharia Química do IPEN (antes denominado IEA). Em 1997 fui para a AIEA em Viena para atuar na Divisão de Apoio Técnico do Departamento de Salvaguardas. Em 2002, retornei para a Coordenação de Salvaguardas e Proteção Física da CNEN (anteriormente, Divisão de Salvaguardas), onde permaneci até 2006 atuando como Líder do Grupo de Proteção Física da CNEN e Ponto de Contato do Brasil junto à AIEA, caso ocorressem eventos de tráfico ilícito de material nuclear no país ou em qualquer outra parte no mundo. A partir de 2006, assumi o posto brasileiro de Oficial de Contabilidade na ABACC, permanecendo até setembro de 2015. Atualmente, estou aposentado pela CNEN.

Quanto à sua pergunta a respeito dos anos iniciais da $\mathrm{ABACC}$, gostaria de começar pela fase "pré-ABACC". Aliás, neste período, nós técnicos ainda não tínhamos qualquer conhecimento sobre a criação da ABACC.

A fim de se dar fim às constantes disputas entre Brasil e Argentina no campo da energia nuclear e eliminar de uma vez por todas a desconfiança entre ambos, a ideia naquele momento era de que, tão logo a Argentina e o Brasil trocassem entre si listas completas dos materiais nucleares presentes em suas respectivas instalações nucleares, os técnicos de ambos os países, através da CNEN e CNEA iniciariam inspeções cruzadas a essas instalações, a fim de verificar contabilmente os valores declarados nestes inventários, e assegurar-se cada qual sobre os usos pacíficos da energia nuclear em cada país.

Com esse objetivo, deu-se inicio uma série de reuniões entre representantes do Brasil e da Argentina, incluindo do Diplomatas do Itamaraty e da Chancelaria Argentina, e de técnicos de salvaguardas de ambos os países (CNEN e CNEA), para estruturar as bases técnicas e procedimentais para a implementação dessas inspeções cruzadas de salvaguardas, no âmbito de um novo sistema denominado de "Sistema 
Comum de Contabilidade e Controle de Materiais Nucleares (SCCC)", concebido com base nas medidas descritas para A aplicação do TNP. Nesta fase, diversos procedimentos operacionais e formulários licença, exportação/importação e usos de material nuclear introduzidos no sistema de licenciamento de instalações e atividades nucleares de acordo com as Normas vigentes de regulação no âmbito das salvaguardas nucleares, já em uso pelas respectivas Autoridades Nucleares de salvaguardas no Brasil e na Argentina, seja no âmbito das salvaguardas domésticas exercidas por estes Órgãos ou das medidas de controle aplicadas pela AIEA, foram cuidadosamente discutidos e revistos visando sua padronização para uso em ambos os países.

Apenas para fins de esclarecimento, o papel de órgão fiscalizador que era exercido pela CNEA naquela época, passou a ser exercido pelo novo organismo que resultou da divisão da CNEA denominado de ENREN, e que mais tarde passou a chamar-se de ARN.

Entretanto, somente a implementação do SCCC, no âmbito do acordo assinado entre os dois países, não davam as garantias suficientes para a Comunidade Internacional acerca dos usos pacíficos da energia nuclear conduzidos pelos respectivos programas nucleares desenvolvidos pelo Brasil e pela Argentina.

Assim, mesmo antes da conclusão da elaboração de todos os procedimentos para a implementação do SCCC, deu-se início à criação de uma Agência BrasileiroArgentina que seria responsável por administrar a implementação deste sistema de salvaguardas. A partir daí, elaborou-se o Acordo Quadripartite (INFCIRC/435), tendo por base o próprio sistema SCCC, com a participação também da AIEA, segundo o qual todas as instalações brasileiras e argentinas passariam a submeter-se a um regime de salvaguardas abrangentes sobre todos os materiais nucleares presentes em ambos os países. Neste, a ABACC não só administra a implementação do SCCC como atua como coordenadora todas as inspeções conjuntas ABACC-AIEA conduzidas nas instalações brasileiras e argentinas, sendo mantido o conceito inicialmente estabelecido das inspeções cruzadas entre brasileiros e argentinos, nomeados inspetores da ABACC.

\subsection{Caso compararmos a ABACC com a AIEA, havia, em sua opinião, na década de 1990, discrepâncias substanciais entre os corpos técnicos das duas agências? Caso existisse, poderiam essas discrepâncias serem supridas por meio da cooperação entre elas preconizada no Acordo Quadripartite?}

Resposta:

Em termos de qualificação, com toda certeza não havia naquela ocasião, e ainda não há, discrepância alguma entre os corpos técnicos das duas agências. Se levarmos em conta o número nitidamente superior de funcionários do Departamento de Salvaguardas da AIEA que atuaram direta ou indiretamente na implementação do Acordo Quadripartite (INFCIRC/435) e em todas as demais atividades de alguma forma relacionadas a este, eu diria que os oficiais técnicos da ABACC poderiam ser considerados até melhor qualificados do que os da AIEA. Além disso, desde o início a ABACC tem com a AIEA um importante acordo de cooperação na área de salvaguardas, além de outros acordos mantidos com as Autoridades Nacionais brasileiras e argentinas, e diversas outras Instituições internacionais. Ainda, principalmente no início da ABACC, esta contou com a ajuda de especialistas reconhecidos internacionalmente em temas específicos para a solução de algumas questões técnicas, como por exemplo, aquelas que se referiam à análise de medidas consideradas as mais eficazes possíveis, requeridas para a aplicação das 
salvaguardas em plantas de enriquecimento, e ainda outras questões de natureza essencialmente técnica, através da implementação destes acordos de cooperação.

Cabe ressaltar também que, já no âmbito do SCCC e para a implementação do Acordo Quadripartite, ambas as Autoridades Nacionais (CNEN e ARN) e CNEA se comprometem a fornecer todo o suporte técnico e humano (especialistas e inspetores) que a ABACC vier a necessitar para o cumprimento de sua missão. Com isso, muitas vezes na condução ou mesmo na preparação de alguma atividade conjunta, a ABACC tem prestado à AIEA enormes contribuições para o sucesso das missões ou no desenvolvimento de sistemas envolvendo procedimentos e equipamentos. Com respeito a estes, a ABACC e a AIEA desenvolvem, estabelecem e aprimoram constantemente procedimentos conjuntos para a aplicação de certas medidas de salvaguardas e sobre o uso conjunto de certos equipamentos para ensaios não destrutivos de material nuclear, e sistemas especiais de contenção e vigilância.

1.3. Outra questão que percebi na literatura foram diferentes ênfases em atores relevantes para a formação da ABACC. Por exemplo, alguns estudiosos falam que a ABACC e o SCCC foram obras do Itamaraty, outros que foi da CNEN e do IPEN, outros, ainda, que foi tudo bolado na Presidência da República. Na sua opinião como observador desse processo, quais foram as agências, ministérios e órgãos brasileiros mais importantes no processo de formação da ABACC?

Resposta:

Eu diria que foram decisões que partiram diretamente dos Presidentes do Brasil e da Argentina. Um vez tomadas essas decisões, foram se implementando as ações decorrentes, conforme citadas na resposta à sua primeira pergunta, sob a orientação e cooperação do Itamaraty e CNEN.

Não tenho conhecimento da participação direta do IPEN, como foi o caso da Divisão de Salvaguardas da CNEN-Sede/RJ (atualmente, Coordenação de Salvaguardas e Proteção Física - COSAP).

\section{O papel dos alemães}

2.1. Ao analisar a literatura, percebi alguma ambivalência entre os autores com relação à formação da $\mathrm{ABACC}$. Alguns dizem que era uma forma de ceder, porém não completamente, às pressões dos Estados Unidos para que Brasil e Argentina aderissem ao TNP, outros dizem que era uma forma de completar o processo de aproximação bilateral entre os dois países (Brasil e Argentina). Ouvi ainda uma terceira versão complementar, do dr. José Luiz Carvalho, que falou que era uma forma de substituir o sistema de salvaguardas e de compartilhamento de tecnologia acordado com os Alemães, em 1975, por um sistema menos intrusivo, porém mais aceito globalmente, visto que envolveria a AIEA (Quadripartite). Qual a sua opinião sobre isso?

Resposta: 
Em parte, considero respondida essa pergunta já no primeiro item. Considero válidas as três argumentações mencionadas em sua pergunta, tendo em conta o exposto a seguir.

O SCCC foi elaborado tomando-se por base o os mesmos procedimentos estabelecidos para a implementação do TNP, sendo no Acordo Quadripartite garantido explicitamente que fossem preservados os segredos tecnológicos e comerciais na implementação das salvaguardas conjuntas da ABACC e AIEA. Vide datas das assinaturas e ratificação do TNP pela Argentina e pelo Brasil.

Outro aspecto importante a considerar é que o Acordo Quadripartite tem por principio básico a confiança mútua entre Brasil e Argentina. Ou seja, acredita-se que todos os materiais nucleares, conforme especificados no SCCC e no INFCIRC/435 com respeito às garantias dos usos pacíficos dessa tecnologia nuclear, estão declarados para a ABACC e AIEA.

Antes do Quadripartite, apenas os materiais nucleares transferidos pelos Alemães e EUA para o Brasil e Argentina estavam sob as salvaguardas da AIEA. Além destes materiais, também estavam sob estas salvaguardas alguns materiais não nucleares e equipamentos (denominados de materiais e equipamentos especificados). Com o INFIRC/435, apenas os materiais nucleares com certo grau de pureza e características definidas no acordo estão sujeitos às salvaguardas atualmente.

Outro aspecto importante é o fato de constar na Constituição Brasileira o compromisso assumido pelo Brasil com respeito aos usos exclusivamente pacíficos da energia nuclear.

2.2. Como perito, qual a sua opinião sobre a viabilidade do método de jato centrífugo (jet noozle), importado pelo Brasil?

Resposta:

Como não me considero um perito nesta área, talvez fosse melhor você encaminhar esta pergunta para um perito em enriquecimento de urânio e não se basear em minha resposta. Pelo pouco que sei trata-se de um método extremamente custoso e pouco eficaz, se compararmos com o processo de ultracentrifugação gasosa. Este último perfeitamente dominado pelo Brasil, a partir do seu desenvolvimento conduzido pelo Centro Tecnológico da Marinha do Brasil - CTMSP.

\section{Adesão ao TNP}

3.1. Em 1998, o Brasil aderiu ao TNP, justificando que era medida necessária para obtenção de transferência de tecnologia nuclear. Há autores, porém, que afirmam que o Brasil aderiu ao TNP como forma de "barganha" com os Estados Unidos no processo de negociação da ALCA. Qual a sua opinião sobre essa adesão? Qual foi o impacto na AIEA da adesão do Brasil ao TNP?

Resposta:

Eu diria que não houve grande impacto na AIEA, pois isso já era de certa forma esperado com a evolução das negociações em direção ao entendimento que se dava na época entre o Brasil e a Argentina. 
Quanto à justificativa de que da adesão ao TNP dependia a transferência de tecnologia nuclear eu concordo. E não era somente tecnologia nuclear, mas qualquer tecnologia

de ponta (supercomputadores e até pequenas peças ou componentes de equipamentos mais sofisticados com espectrômetros de massa, por exemplo, e certos padrões analíticos).

3.2. Como inspetor nuclear e perito em salvaguardas, qual a sua opinião sobre a tese do uso de explosões nucleares para "fins pacíficos", a tese das "explosões pacificas", o qual constituiu um dos argumentos brasileiros para não aderir ao TNP e uma das ressalvas desse país ao Tratado de Tlatelolco?

Resposta:

$\mathrm{Eu}$, particularmente, discordo veementemente dessa tese e não aceito como pacifica esta prática. Aliás, até onde tenho conhecimento, o Brasil tem dado importantes contribuições para o monitoramento e detecção dessas explosões no âmbito de sua participação ativa nas reuniões do CTBTO.

\section{Questão do Urânio}

4.1. Quão amplo é o acesso da ABACC aos programas nucleares brasileiro e argentino, no que concerne ao controle de material nuclear (urânio natural, yellow cake, plutônio, etc.)?

Resposta:

Tanto a ABACC quanto a AIEA têm total acesso aos materiais e instalações nucleares em ambos os países, respeitados, como consta no Acordo Quadripartite, a preservação dos seus segredos tecnológicos e comerciais, conforme requerido para as instalações consideradas sensíveis, como é o caso das instalações de enriquecimento de urânio.

O yellow cake é considerado, segundo definição que consta do SCCC (e TNP) e Quadripartite, como sendo um material nuclear que se encontra antes do ponto de inicio das salvaguardas, tendo em conta grau de pureza e certas características. Isto é, este material não está sujeito ao controle das agências, conforme estabelece o Acordo Quadripartite em vigor. Entretanto, a partir de entendimentos ocorridos entre Brasil, Argentina e AIEA, ambos os países comprometeram-se a informar à AIEA, em forma voluntária, todas as importações e exportações ocorridas de Yellow cake.

Já os inventários e qualquer alteração ocorrida nestes valores de materiais de Urânio (natural, enriquecido ou empobrecido), Plutônio e Tório são obrigatoriamente informados às agências periodicamente e/ou sempre que ocorram variações, através de relatórios contábeis, para uma posterior verificação conduzida durante as inspeções conjuntas de salvaguardas realizadas pela ABACC e AIEA.

4.2. Em entrevista com um determinado inspetor nuclear (anônimo), ouvi que, até hoje, o Brasil ainda possui urânio enriquecido adquirido clandestinamente de países como a China. Embora Brasil e China tenham negado essa transferência, há documentos telegráficos, datados da época do governo Figueiredo, que afirmam 
que o Brasil chegou a negociar a compra de urânio da República Popular da China, possivelmente em grau bomba (enriquecido a mais de $90 \%$ ). Aquele mesmo inspetor afirmou que o Brasil, ainda hoje, declara, eventualmente, à AIEA a existência de determinadas quantidades de urânio enriquecido de origem desconhecida (possivelmente chinesa) datadas daquela época. O senhor tem e poderia dar alguma informação sobre isso? Caso positivo, estaria esse urânio contabilizado pela ABACC, porém não pela AIEA? Haveria informações ou relatos sobre o destino desse urânio clandestino? Em caso positivo, por que ele continuaria clandestino?

Resposta:

Pelo que sei, já no início do SCCC e do Acordo Quadripartite todos os materiais nucleares tiveram que constar das listas de inventários enviadas para as agências. E, se por acaso, algum material, por algum descuido tenha ficado fora dela, certamente com este tempo todo já foi incorporado ao inventário e declarado, nesse caso, como um ganho acidental de material nuclear.

Lembro-me vagamente de certa quantidade de urânio proveniente da China, mas esse material também foi declarado para a $\mathrm{ABACC}$ e, consequentemente para a AIEA. Pelo que sei, por ser de alto enriquecimento, esse material sofreu redução deste enriquecimento transformando-se em material de baixo enriquecimento para uso em algum processo e, portanto, não tem nada de clandestino.

Desconheço quaisquer evidências que conduzam à possibilidade de haver material clandestino e, particularmente, não creio que nem Brasil e nem Argentina se arriscariam a manter até hoje algum material que já não tivesse sido declarado para a ABACC e AIEA, desrespeitando os acordos em vigor (SCCC e INFCIRC/435).

4.3. Sei que isso não se relaciona, diretamente, à $\mathrm{ABACC}$ ou à AIEA, mas, ao fazer minha pesquisa documental, percebi que estão disponíveis todos os relatórios da CNEN desde a década 50, salvo o de 1975 e os realizados entre 1990 e 1995 . Ouvi que uma razão para isso poderia ser, justamente, a questão da contabilidade do urânio obtido durante o regime militar. $O$ senhor acha que essa suspeita se confirma?

Resposta:

Para essa sua pergunta, infelizmente não sei a resposta. O que sei é que naquela época, os materiais sujeitos às salvaguardas da AIEA eram apenas aqueles transferidos pela Alemanha ou Estados Unidos por força dos Acordos de Transferência de Tecnologia e Instalações como os reatores de pesquisa, por exemplo, e que obedeciam aos Acordos de Salvaguardas assinados pelo respectivo país, o Brasil e a AIEA. 
Anexo 7 - Entrevista com José Luiz de Santana Carvalho, concedida em 18 de fevereiro de 2016.

Nota biográfica: José Luiz de Santana Carvalho é professor da UFRJ. Foi presidente da CNEN durante o governo Collor.

Metodologia: a entrevista foi realizada oralmente, via telefone. Não houveram perguntas previamente formuladas. A transcrição está dividida por temas.

\section{Íntegra da entrevista:}

\section{Presença de Urânio enriquecido sigiloso no Brasil}

\subsection{O que é sabido sobre o urânio enriquecido obtido para abastecer o programa paralelo?}

Não sabemos o quanto (de urânio enriquecido) o Othon (Pinheiro) puxou não sabemos se é correto o que o Othon disse que tinha, pois, até hoje, ainda aparecem miligramas de urânio enriquecido chinês a ser contabilizado e salvaguardado pelo IPEN.

Nem todo urânio enriquecido, grau bomba, foi contabilizado em 1990 pela CNEN e pela ABACC, ou seja, algum urânio ficou de fora. Outro tanto, ficou fora de controle e escondido. Quem estava em posse desse urânio? Um sinal (da existência) desse urânio e (que) um pesquisador do IPEN (pode) vir hoje e falar que esqueceu. Isso implica que, naquela época, algumas pessoas do IPEN sabiam daquele urânio. Agora, a questão é saber - por que elas tem acesso? A não ser que fosse o paralelo do paralelo, porque esse urânio chinềs só entrou em salvaguardas em agosto de 1990, de modo que teria mais tempo (do) que (o) suficiente, meses, para decidir destino alternativo para parte do urânio.

O que está acontecendo na CNEN para eles devolverem agora esse urânio, e (o que ocorreu com o) urânio grau bomba (mais de 90\%)? 0 [único problema que o Othon relatou é que era urânio grau sujo, ou seja, daria para fazer uma bomba, mas bomba suja, de modo que teria algumas coisas que seriam radioativadas.

\subsection{Qual foi a participação da CNEN no processo de formatar a ABACC? E qual foi a participação dos americanos?}

Quando estudava em Berkeley, Glenn Seaborg (antigo presidente da Comissão de Energia Atômica dos EUA), me chamou e disse que iria dar acesso a documentos confidenciais da House of Representantives, para entender melhor a posição dos Estados Unidos e como eles enxergavam o Brasil. Ele deu esses depoimentos sigilosos e lá eu vi, por exemplo, Kissinger falando, claramente, que seria bom para os Estados Unidos, que os países do Cone Sul e juntassem para fazer enriquecimento de urânio em conjunto, pois ai cada pais estaria fiscalizando o outro e os EUA não precisariam fiscalizar todo mundo. Era mais fácil monitorar o conjunto do que cada um em separado. Substituir o big brother por regime 
regional. Isso, Kissinger fala nos anos 1960! Essa era a proposta dos Estados Unidos, que sempre aparecia na pressão contra o programa paralelo - por que vocês não fazem enriquecimento em conjunto com a Argentina?

Houve uma reunião em Buenos Aires, no Palácio San Martín, que Celso Amorim era co-presidente, junto com o Rafael Mondino (embaixador Argentino) e com outro embaixador (cujo nome o entrevistado não se recordava). Esse embaixador argentino sugeriu que tivéssemos inspeções mútuas ou bilaterais. A posição da CNEN foi (a) de que o Brasil não seria big brother para os EUA e (de que o Brasil) não espionaria a Argentina. Deveria haver uma filosofia de verdadeira fraternidade entre os dois países, pois não havia diferença política, cultural, religiosa, etc. entre nós. "Podíamos fazer inspeções mútuas, mas como irmãos, como iguais, (ou seja,) vou ser mais aberto com você do que o resto". A ideia era as comissões dos dois países fazerem inspeções mutuas, ou seja, visitas técnicas. Isso aconteceu duas semanas depois e, na outra semana, o processo (de aproximação formal) começou.

\subsection{Como se deram as negociações com os alemães para viabilizar a conformação do Acordo Quadripartite?}

A ideia das inspeções mutuas era tirar a pressão (internacional) de cima do Brasil e fazer com que os dois (Brasil e Argentina) fossem parceiros. Duas semanas depois, fizemos acordo com a Alemanha para substituir os acordos de salvaguardas (de 1975), pois (eles) era(m) muito comprehensive. Por exemplo, (qualquer) tecnologia desenvolvida pelo Brasil seria, dentro do acordo, de (co-)propriedade alemã. A ideia era substituir o acordo com (os alemães por) um com a AIEA. A agência ajudou a fazer pressão e os alemães cederam. Tática de negociação: vocês vão pagar cada vez que as usinas pararem por causa de inspeções?

A linha de inspeções mútua não era light, mas pesada. No primeiro mês da posse dele isso tudo ocorreu, quando foram para a Argentina. Esse assessor que era oficial da Marinha, reformado, Bernardino Campos, deu todas as grandes sugestões na área de inspeção. Ele que me sugeriu e que me convenceu a criar a ABACC. O que fiz foi transformar essa lógica (de inspeções mútuas) em um "algodão nuclear", ou seja, a ABACC seria um anteparo entre nós (Brasil e Argentina) e a AIEA. Outra coisa importante sobre a ABACC era que a decisão final não era daquela organização, mas sempre de outras pessoas - pessoas técnicas, como doutores treinados em salvaguardas. Antes de serem servidores da ABACC, esses técnicos eram servidores da CNEN e da CNEA, as duas comissões que mandavam na ABACC.

Na Alemanha, o principal aliado foi o Partido Verde. Eles (os integrantes do partido) eram contra o acordo Brasil-Alemanha. Somente quando um funcionário da CNEN foi conversar com os membros do PV, que a coisa melhorou, pois tratouse da credibilidade pessoal. No governo Collor, a CNEN passou a ser transparente. Esse funcionário pediu para eles não se oporem à troca de salvaguardas alemãs pelas da AIEA. Quando falamos a troca de salvaguardas pelas da Agência (comunidade internacional), eles perceberam que não faria sentido manter as dos alemães, haja vista que eles também eram comunidade internacional. Por isso, eventualmente, o Brasil pode usar as instalações do Acordo Brasil-Alemanha dentro do (sistema de salvaguardas) nosso acordo (, o Quadripartite). 
0 argumento para descontinuar o acordo com a Alemanha foi outro: a tecnologia não funciona! Até aquele momento, eles não mostraram um miligrama enriquecido com essa tecnologia (do jato centrífugo)! Consultamos, então, advogados alemães que disseram que, dentro de uma situação como essa, os o governo alemão tinha de entregar um quadro técnico da tecnologia. Se esse quadro mostrasse que a tecnologia era inviável, como aconteceu, logo na montagem (das usinas), o Brasil teria direito a ser ressarcido naquilo que tinha gastado até então e a quebrar com o contrato. Esse foi um outro argumento muito forte para "tirar a Alemanha do meio", pois eram várias as instalações construídas dentro do acordo Br-Alemanha (NUCLEI, NUCLEP, etc.)

Outro fator importante foi a dívida da área nuclear com o tesouro nacional. O Brasil tomou empréstimo lá fora para pagar essa divida - algo como 3 bilhões de dólares, que era jogada no balanço de Furnas. Furnas, que na parte não nuclear dava muito lucro, tomava prejuízo na parte nuclear e tinha dificuldades de fechar o balanço por causa dessas dívida. Então, para sanear toda a área (beneficiamento etc.), propusemos que a dívida nuclear fosse transferida para o tesouro nacional. Quando se fez isso, o balanço de Furnas foi limpado. Ainda mais, a conta elétrica da época, que tinha um percentual extra para pagar a dívida nuclear, reduziu. No final, quem passou a dívida para o tesouro e quem "bateu o martelo" foi o presidente Collor. Quando a dívida foi passada para o tesouro, Furnas como um todo passou a dar lucro. A dívida foi para "o bolão" do resto das dividas do pais. 